Historic, Archive Document

Do not assume content reflects current scientific knowledge, policies, or practices. 

6291

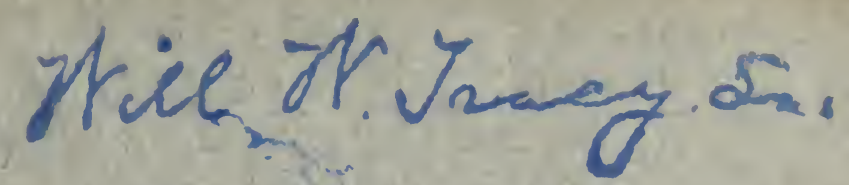

$$
1913
$$

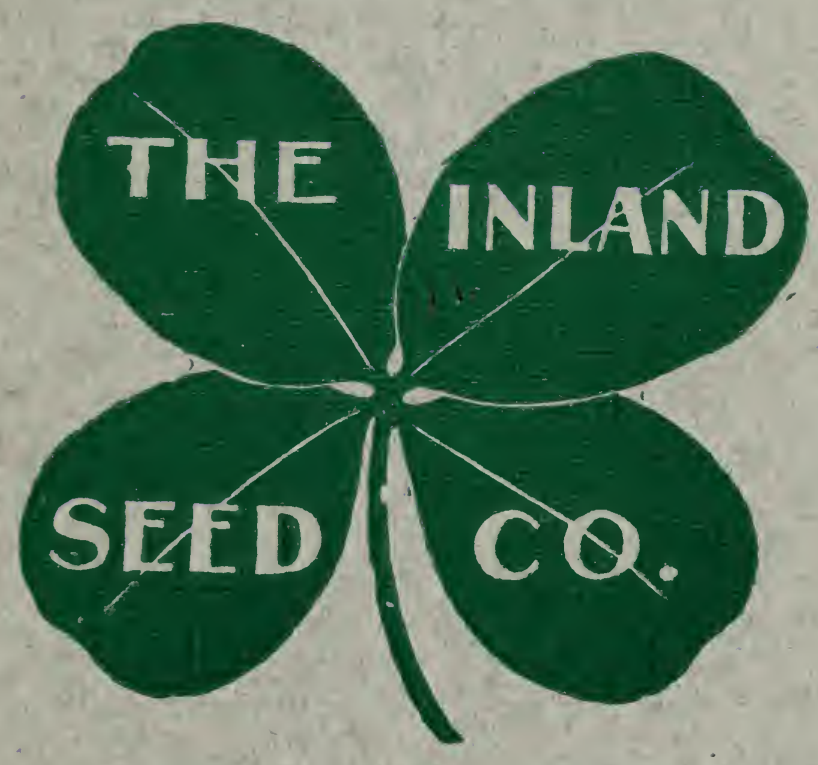

SPOKANE, WASHINGTON

913-915 FIRST AVENUE 


\section{The Inland Seed Co. SPOKANE, WASH.}

\section{To Our Customers:}

We take pleasure in handing you herewith our Annual Catalogue. Many of you have received this book regularly, and it has been a pleasure to us to see your orders coming to us each year. Our Catalogue is different from many. Not as large and highly colored, but plain and straightforward, showing things as they are. We have arranged, as near as we could, everything under each department where it belongs., making it easier to find and easier to make out your orders.

Trusting that our Catalogue will please you, and that we will be favored with your business, we remain

\section{Very truly yours,}

THE INLAND SEED CO.,

\section{SUGGESTIONS}

Spokane, Wash.

LARGE ORDERS. Any dealer, market gardener, institution or individual wishing seed in large quantities is requested to mail us a list of what is wanted, an dwe will promptly return it with the very lowest market prices. A letter of inquiry may save you dollars if you want to buy ia quantity.

SEND MONEY BY Postoffice or Express Money Order, Bank Draft or Registered Letter. Postage stamps will be accepted for small amount. Money sent in any way is entirely at sender's risk.

USE ORDER BLANK in the front of the Catalog, carefuily fllling out the blank spaces at the top for shipping directions.

BE SURE TO SIGN YOUR NAME, giving postoffice and state. Do not write letters on the same sheet as orders.

NEW PARCELS POST IAW. Seeds, bulbs, roots and plants will remain the same as heretofore-that is, two ounces for one cent-with the exception that eleven pounds can be sent instead of four.

Any fourth-class matter is mailable if not over 11 pounds in weight nor more than 72 inches in length and girth combined, nor likely to injure the mails or postal equipment or employes.

There is a flat rate of 1 cent an ounce up to four ounces, regardless of distance. Above four ounces, rates are by the pound or fraction. thereof, and vary with distance, as follows:

$$
\text { First Each Eleven }
$$

Pound. Add. Pound. Pounds.

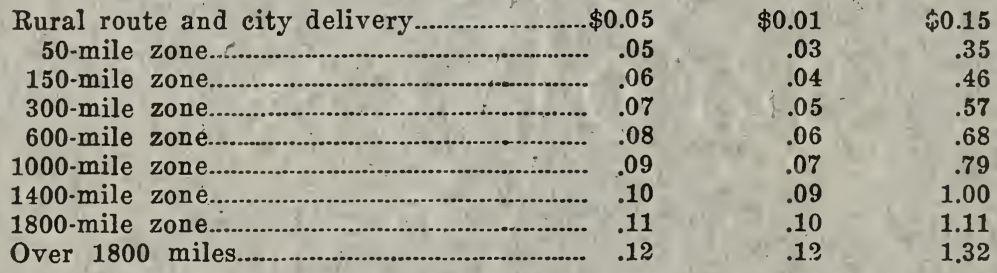

The postmaster general may make provisions for indemnity insurance and collection on delivery, with additional charges for such service, and may, with consent of the interstate commerce commission, after investigation, modify rates, weight and zone distances when experience has demonstrated the need therefor.

SEEDS POSTPAID BY MAIL. We send all vegetable and flower seeds in quantities of one pound or less by mail, postpaid, to any postoffice in the United States, at the prices named in this Catalog, unless otherwise stated.

PREPAY STATIONS. When you send in orders to go by freight or express be sure that you add money enough to pay freight charges if your station is a prepay, which is always the case where there is no regular agent.

GUARANTEE. Our seeds are all tested fcr germination, and if not up to standard are destroyed. Complaints made that seeds are no good should quite as often be attributed to other causes as to the quality of the seeds. There are hundreds of contingencies constantly arising to prevent the bost seeds always giving satisfaction, such as sowing too deep, too shallow, in too wet or too dry soil; insects of all descriptions destroying the plants as soon as or befors they appear; wet weather, cold weather, frosts, chemical changes in the seeds induced by temperature, etc. For the above reasons it is impracticable to guarantee seeds under all circumstances. We give no warranty, express or implied, as to description, purity, productiveness, or any matter of any seeds we send out, and we will not be in any way responsible for the crop. If the purchaser does not accept the goods on these terms they are at once to be returned. 


\section{Some Splendid New Introductions}

\section{NEW EARLY CABBAGE, COPENHAGEN MARKET}

The earliest large round-headed cabbage yet introduced. The heads are of exceptionally large size for so early a variety. The plant is of vigorous habit, but compact, with short stem and few outer leaves, which are of rather upright growth. The leaves are medium light green, nearly round, comparatively thick and smooth. The heads areround, very solid and of exceptionally good quality. Its earliness, compact growth, uniformity and size of head, firmness and most excellent quality combine to make Copenhagen Market the most valuable cabbage of recent introduction. We recommend it unreservedly both for the home garden and the market gardening trade. Pkt., 10c; oz., 60c; 1/4 lb., $\$ 1.75$.

\section{DANISH "ROUNDHEAD" CABBAGE \\ An Earlier Shorter Stemmed Type of the Famous Danish "Ballhead"}

THE ORIGINAL DANISH BALL HEAD Cabbage has become very popular with market growers on account of the extreme solidity and great weight of the heads, as well as for its superior keeping qualities. At the same time, however, there has always been more or less objection to the rather long stem of this variety. For this reason a shorter stem type has been selected and bred up until it is now very uniform. This shorter stem strain has been given the name of Danish Round Head.

This variety, although of very robust growth, has rather less outer leaves than the original strain, and many growers consider it better able to resist blight. In fact, it is as vigorous in growth as the best American varieties. The heads are fully as large and even heavier, and of equally good quality, maturing about a week earlier. Heads are beautifully white when trimmed, and keep full as well when stored. Our seeds of this short stem strain is direct from the same grower in Denmark, who furnishes our long stem strain. Pkt., 10c; 0z., 30c; 1/4 1b., 90c; 1b., $\$ 3.00$.

\section{DANISH GIANT OR DRY WEATHER CAULIFLOWER}

This strain is offered in view of its special features recommending it as a safe crop variety. In seasons of especially dry weather, and in sections of the country where warm weather prevails, and little or no cold weather, this is a very desirable sort. It has proven itself of exceptional merit under the conditions named. It is very sure heading and second early; heads larger than "Snowball" and are snow white. Our seed is A1 and procured from the original grower in Denmark. There should be at least a portion of any large acreage planted to this variety. Pkt., 10c; 1/2 0z., $\$ 1.50 ;$ oz., $\$ 2.50$.

\section{DAVIS' PERFECT CUCUMBER}

Of the extra long "White Spine Type," the "Davis Perfect" fulfills the requirements of the demands for this type of cucumber better than any other variety. This fact is clearly shown in the Northern States, where the Davis is the most popular cucumber of this kind. A veteran grower of outdoor and greenhouse cucumbers made the original selection, and the most desirable cucumber features, length, slimness, and dark green color are combined in this strain, together with extreme vigor in growth, and great productivity. . The remarkable vigor of this variety makes it a better blight resister than other long sorts. In popular favor it stands pre-eminent among all other extra long, white spine cucumbers, both for indoor and outdoor planting. Our seed has been most carefully selected under our supervision each year, and we offer a more uniform strain each season. Pkt., 10c; 0z., 15c; 1/4 lb., 40c; lb., \$1.25.

\section{NEW DELICIOUS SQUASH}

We are convinced that this fall and winter squash is particularly excellent in quality, and in that respect it is now by many considered even better than the Hubbard, which has been so long looked upon as the standard. The fruits are of meciium size, moderately hard, usually dark green in color and are without any hard shell. The flesh is thick, becoming when cooked deep yellow in color, and very fine grained. Although when first introduced a little uneven in shape and exterior color, we have by continued and careful selection made a marked improvement in uniformity of type. Pkt., 10c; 0z., 15c; 1/4 lb., 40c; lb., \$1.25.

\section{NETTED GEM POTATO}

The hardiest, most vigorous in growth, most productive, and the best in table quality of all potatoes, it has proved to be unequaled for main crop. The vines are strong, with deep green foliage, making a healthy growth when other varieties are cut down by blight. In form the tubers are medium long, the eyes are small and there is very little waste in paring. The skin is thin and very smooth with the exception of very small depressions which give it the appearance of being netted and from which it derives its name. The color reminds one of a Golden Russet apple. The flesh is fine-grained and cooks up mealy white. It is very free from scab and one of the very best keepers on the market. One grower tells us that they were in excellent condition in October, one year after being dug. These potatoes command the highest prices in all markets where they have been introduced. Price postpaid, $3 \mathrm{lbs}, 60 \mathrm{c}$; freight, $25 \mathrm{lbs}, \$ 1.25 ; 1001 \mathrm{bs} ., \$ 3.00$. 


\section{The Essentials to the Production of GOOD VEGETABLES AND BEAUTIFUL FLOWERS}

GOOD SOIL

A rich, sandy loam is the best, but a fair degree of success may be secured from any soil which ean be made rich and friable. Vegetables of the best quality cannot be grown on barren sand, a cold, hard, lump clay, nor in the shade of orchard or other trees.

\section{LIBERAL MANURING}

A soil which does not need enriching in order to produce the best results is rarely found, and very often success is in proportion to the liberality with which fertilizers have been used. Well decomposed stable manure, where straw bedding has been used is the best; manure where sawdust has been used for bedding is not so good. Often wood ashes at the rate of one peck up to one bushel to the square rod will be of great benefit. Commereial fertilizers are excellent and may be used at the rate of four to twelve pounds to the square rod, and the more concentrated forms, such as Nitrate of Soda, Guano, Dried Blood and Potash Salts, at the rate of one to six pounds to the rod, the larger amounts preferably in three or four applications and at intervals of about ten days. A mass or lump of any of the commercial fertilizers, even if it is but a quarter of an inch in ciameter, is liable to kill any seed or young plant which comes in contact with it, so it very important if such fertilizers be used that they be thoroughly pulverized and mixed with the soil.

\section{THOROUGH PREPARATION}

Rich soil and liberal manuring will avail little without thorough preparation. The soil must be made friable by thorough and judicious working; if this is well done, all that follows will be easy.

\section{GOOD SEEDS PROPERLY PLANTED}

There is no more prolific source of disappointment and failure among amateur gardeners than hasty, careless or improper sowing of the seed. A seed consists of a minute plant enclosed in a hard and more or less impervious shell with a sufficient amount of food stowed in or around the germ to sustain it until it can expand its leaves, form roots and provide for itself. Moisture, heat and a certain amount of air are necessary to secure germination. The germinating seed first absorbs water and swells. The starchy matter gradually become soluble. The seed-coats are ruptured, the stemlet and bud emerge. The embryo lives for a time on the stored food, but gradually the planlet secures a foothold in the soil and gathers food for itself. Germination is complete when the plantlet is able to shift for itself. A dry seed may retain its vitality and remain unchanged for years, but after germination has commenced, a check of a day or two in the process may be fatal. There is no time in the life of a plant when it is so susceptible of injury from the over-abundance or want of sufficient heat and moisture as at the period between the commencement of germination and the formation of the first true leaves. It is just then that the gardener should aid in securing favorable conditions. These are:

FIRST-A proper and constant degree of moisture. The soil should always be moist-never wet. To secure this, cover the seed as soon as it is planted with well pulverized, freshly prepared earth, pressing it firmly over the seed. This firming of the soil is very important, as it brings the particles of earth into close contact with seeds and roots, prevents the drying out of the soil and facilitate: quick growth. The best results are obtained in small gardens by laying a board on the row and then walking upon the board, or the back of the hoe may be used; but for truck farms and fields crops, a roller is equally satisfactory.

SECONDA proper degree of heat, secured by sowing the seed when the temperature of the soil is that most favorable to the germination of the seed of that particular plant. Too high a tempera. ture is often as detrimental as one too low. The proper temperature for each sort may be learned from a careful study of the following pages and the experiences of the most successful gardeners in your vicinity.

THIRD-Covering the seed to such a depth that while a uniform degree of heat and moisture is preserved, the necessary air can readily reach the germinating seed and the tiny stem push the forming leaves into the light and air. This depth will vary with different seeds and conditions of the soil and can be learned only from practical experience. In general, seeds of the size of the turnip shonld not be covered with more than half an inch of earth pressed down, while corn may be an inch, beans an inch to two inches, and peas one to three inches deep.

FOURTH-Such a condition of soil that the ascending stem can easily penetrate it and the young roots speedily find suitable food. We ean usually secure this by thorough preparation of the ground and taking care never to sow fine seedswhen the ground is wet. Occasionally a heavy or long continued rain followed by a bright sun will so bake and crust the surface that it is impossible for the young plant to find its way through it, or a few days of strong wind will so dry the surface that the young plants will be killed. In such eases the only remedy is to plant again.

\section{JUDICIOUS CULTIVATION}

Not only should every weed be removed as soon as it appears, but the crust which forms after a rain should be broken up and the ground stirred as soon as it is dry enough to permit it. The more frequently and deeply the soil is stirred while the plants are young, the better, but as they develop and the roots occupy the ground, cultivation should be shallower until it becomes a mere stiring of the surface. The yield and quality of regetables have ofeu been decidedly lowered by injudiciously deep and close eultivation after the roots of the plants had fully occupied the ground. A very small garden, well cultivated and eared for will give larger returns and be in every way more satisfactory than a much larger one poorly prepared and neglected. 


\section{ORDER BLANK}

\section{FOR NORTHERN GROWN \\ SERDS TROM}

\section{The Inland Seed Co., Spokane, Wash.}

No Goods Sent C. O. D. For full instructions about Ordering, see inside Front Cover.

THE INIAND SEED CO. gives no warranty, express or implied, as to description, purity, productiveness or any other matter of any seeds or bulbs they send out, and they will not be in any way responsible for the crop. If the purchaser does not accept the goods on these terms they are at once to be returned.

Forward by P. O. Money Order \$ (State on this line whether wanted by Mail, Express or Freight.

Your Name

Postoffice

County

State

Express or

Freight Office
Exp. Money Order $\$$.

Notes and Silver - $\$$

Postage Stamps - - $\$$

Total - - - $\$$.

Date. 191

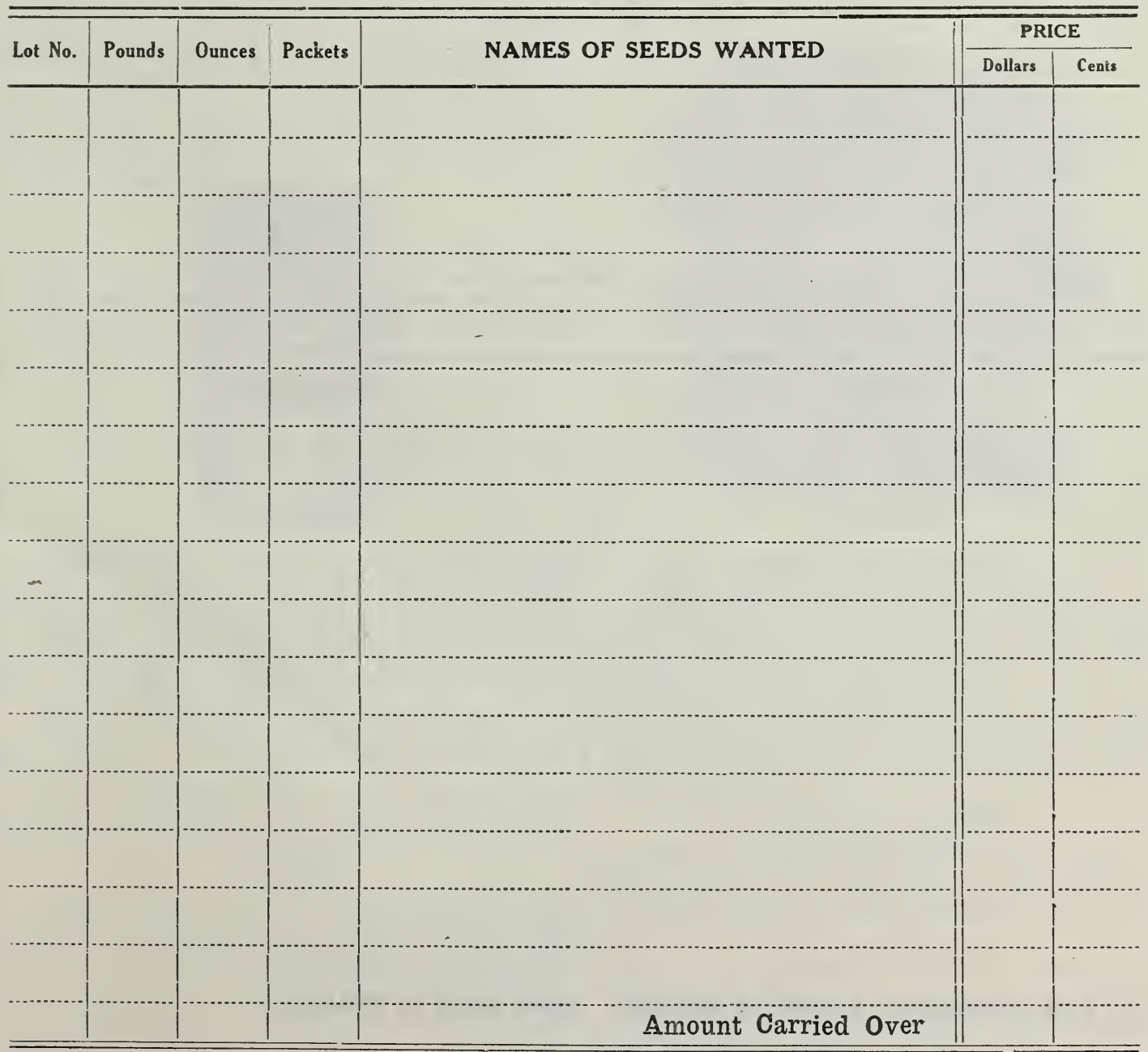




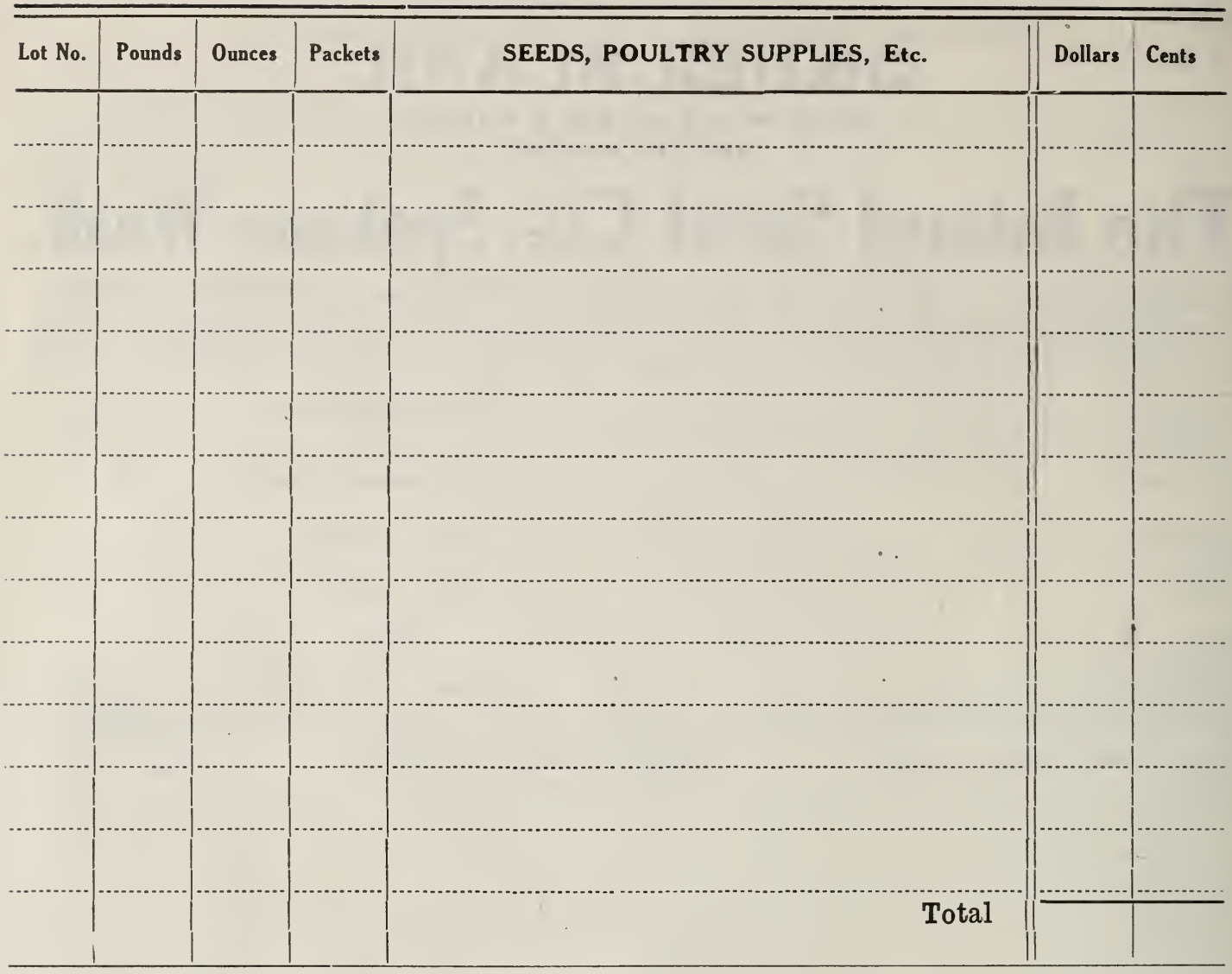

If you will fill in the spaces below, the names and addresses of ten of your neighbors, who buy Seeds, Plants, Bee or Poultry Supplies, Fertilisers, Sprays or Spray Pumps, you may with your first order of 25c or over, select free of charge any two 5c papers of seeds that we list. We rely upon your honesty to send us good, reliable names.

\section{NAME}

ADDRESS

This Catalogue is printed in Spokane; paper made in Spokane. 
General Directions for Cultivation

\section{ARTICHOKE SEED}

CULTURE-Sow in April in rich soil and transpiant the following spring to permanent beds (in rows or hills) three feet apart and two feet between the plants. Green Artichoke only gives a partial crop the first season, but the beds will be bearing for years. Protect in winter by a covering of leaves or coarse manure.

GREEN GLOBE-Grown for the unripe flower heads, which are highly esteemed by epicures. Large pkg., luc.

\section{ARTICHOKE TUBERS}

ARTICHOKE TUBERS-Planted and cultivated the same as potatoes. Of great value for feeding stock. They are the best hog feed known. They are remarkable for their fattening properties, great productiveness (over one thousand bushels having been raised on one acre) and ease with which they can be grown. If hogs are turned in on them they will help themselves by rooting. One lb., postpaid, 15c; 100 lbs., \$2.50.

\section{ASPARAGUS SEED}

One ounce will sow 50 feet of drill.

CULTURE-Sow early in snring in rows one foot apart: when one year old the roots may be taken up and transplanted in permanent beds, which should be made by taking out the soil to a depth of about 16 inches, fill in with 6 inches well-rotted stable manure, then 6 inches of soil, somewhat firmed, and place the roots on the same abour iv inches apart with the roots well spread out and cover so that the crown will be about 4 inches below the surface. Keep he surface well raked to keep down the weeds until the shoots start.

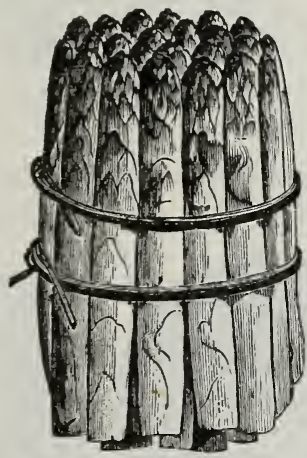

PALMETTO-This variety is of southern origin, very desirable on account of its earliness, bright green color, presenting an attractive appearance, excellent flavor and productiveness. Pkt., 5c; 0z., 10c; $1 / 4$ lb., 25c; lb., 65c.

COLUMBIA MAMMOTH WHITE-A newer, distinct and valuable variety. The stalks are white of the largest size; very productive and earlv. Pkt., $\mathbf{5 c}$; oz., 10c; 2 oz., 15c; $1 / 4$ lb., 25c; 1b., 75c.

CONOVER'S COLOSSAL-A standard sort; quality first class, spreads less than other sorts. Yields from 10 to $: 30$ sprouts from a single plant. Pkt.. 5c; oz., 10c; $1 / 4$ lb., 20c; lb., 65c.

BARR'S MAMMOTH-A farorite with market gardeners. Shoots very large, tender, quick growing, and thick to the top. Pkt., 5c; oz., 10c; $1 / 4$ lb., 25c; 1b., S5c.

\section{BEANS}

CULTURE-Beans should not be planted until the ground is warm, as cold and wet weather will cause the seed to rot. For garden culture plant four or five seeds in hills one foot apart, and the rows 18 inches apart. For field culture, make the rows 3 or $3 \frac{1}{2}$ feet apart, and cover with two inches mellow soil. Do not hoe or cultivate while the plants are wet with dew or rain, as getting the leaves bespattered with earth causes rust, which injures the crop.

\section{Wax Pod Varieties}

IMPROVED GOLDEN WAX BEAN-This is the favorite early wax varietr. more largely used than any other. The nods are yellow. stringless, large and handsome. Very productive. Large pkt., 5c; lb. 25c postpaid, express or freight; lb., 1.sc; 10 lbs., \$1.25.

PROLIFIC BIACK WAX BEAN-A very early wax podded sort: pods round, stringless and of exceptionally delicate and fine quality. Large pkt.. $\bar{x}$; lb.. 2.c postpaid, express or freight; lb., 1.cc; 10 lbs., $\$ 1.25$.

WARDWELL'S KIDNEY WAX BEAN-This splendid early variety has a pure wax pod, is entirely stringless, and almost rust-proof, as it holds its pods so high above the ground. Large pkt., 5c; 1b., 25c postpaid, express or freight; $1 \mathrm{lb.,} \mathrm{15c;} 10 \mathrm{lbs} ., \$ 1.25$.

DAVIS WHITE WAX-A hardy, rustless and immensely productive bush variety. The pods are long, nearly straight, white and handsome; cooked when young they are tender, juicy and of fine flavor. The dried bean is kidney shaped, clear white, and a favorite for baking and canning. Popular with canners and market gardeners. Pkt., 5c; lb.. 25c postpaid, express or freight; $1 \mathrm{lb} ., 15 \mathrm{c}$; 10 ibs., $\$ 1.25$.

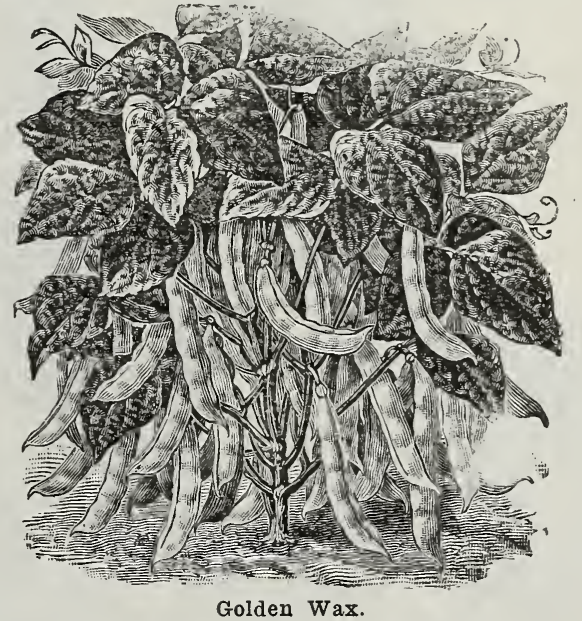

\section{Green Pod Varieties}

EXTRA EARLY ROUND POD RED VALENTINE-The best green podded, "snap short" bean. The pods are of good quality; this is the most popular of all the greenpodded beans. Large pkt., 5c; lb., 25c postpaid, express or freight; $1 \mathrm{lb} ., 15 \mathrm{c} ; 10 \mathrm{lbs}$., \$1.25.

NEW STRINGLESS GREEN POD-Long, round, green pods, absolutely stringless; tender, brittle and of finest flavor. While more hardy to withstand frosts, yet it is as tender to cook as any wax pod bean. Early and productive. Pkt., 5c; lb., 25c; postpaid, express or freight; $1 \mathrm{lb.,} 15 \mathrm{c}$; 10 lbs., \$1.25.

\section{Dwarf Horticultural}

DWARF HORTICULTURAI-Grows erect, strong and shrubby. The bean is highly prized, green shelled. It is rather large, plump, and beautifully mottled yellow and red. Pkt., 5c; lb., 30c postpaid, express or freight; $1 \mathrm{lb}$., 20c; 10 ibs., \$1.50.

\section{Broad Windsor.}

BROAD WINDSOR-Stock erect, strong and shrubby. The bean is large, broad and flat: it is the best green shelled. Pkt., 10c; lb., 25c postpaid, express or freight; $1 \mathrm{lb}, 15 \mathrm{c} ; 10 \mathrm{lbs}$., $\$ 1.50$. 


\section{BEANS-Continued}

\section{Burpee's Bush Lima}

BURPEE'S BUSH LIMA-The true bush form of the old large Lima Pole Bean. It grows vigorously to a height of 18 to 20 inches, forming a circular bush, two or two and a half feet in diameter, requiring no noles or stakes, yielding from 50 to 150 fine pods, similar in size and qual ity to those grown on large White Lima Beans. Large pkt., .c; lb., s0c postpaid. express or freight; 1 lb., 20c; 10 lbs., \$1.50.

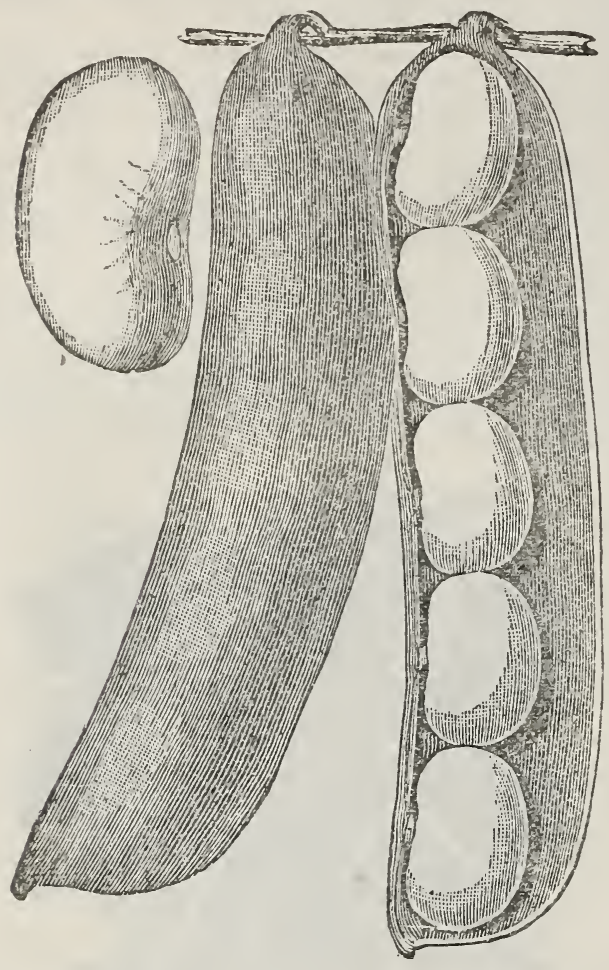

\section{Pole or Running Beans}

I.AZY WIFE-The pods are nroduced in large clusters in great abundance and are from four to five inches in length. Dark green, rather flat but broad ouite thick, fleshy, and Dutirely stringless, retaining their brittleness until fully developed; of unusually rich flavor. The dry beans are pure white in color; excellent for winter use. Ib., $30 c$ postpaid, express or freight; 1 lb., 20c; 10 lbs., \$1.50.

IONDON HORTICULTURAI OR SPECKLED CRANBERRY-Vines moderately viororous, with large, light-colored leaves and purple blossoms; pods short broad, pale green but becoming streaked with bright red: beans large, ovate, splashed and spotted with wine red and of the highest quality, either dry or green. Ib., 30c postpaid; 1b., 20c; 10 lbs., \$1.50.

KENTUCTKY WONDER (Old Homestead)-Best variety. round and fleshy. they mature quickly and are excellent for use in green state. Fnormously productive. Lb. 30c postpaid, express or freight; 1 lb., 20c: 10 lbs., \$1.50.

DUTCH CASE KNIFE-Good corn hill bean; very early; pods long and flat; beans, white; used green or dry. Pkt., 10c; 1b., 30c postpaid; lb., 20c; 10 lbs., \$1.50.

CASTOR BEAN-Used for medicinal purnoses, and hy some claimed to keep moles away. Pkt.. 10c; 1b., 3.ic postpaid.

NAVY BEANS-Price, per 1b., 25c postnaid.

LADY WASHINGTON-Price, per lb., 2.ic postpaid.

\section{BEETS}

CULTURE-Sow as early in the spring as the ground can be worked, and every two weeks thereafter, up to the middle of July. For general crops, sow about the 20th of May. The soil should be deep, rich and mellow, plowed deep and harrowed until very fine, Drop about one inch deep in drills 12 to 18 inches apart, and when well up thin to four or six inches. The tops of the young beets can be used for greens. One ounce will sow a 60 -foot drill. Six pounds to the acre.

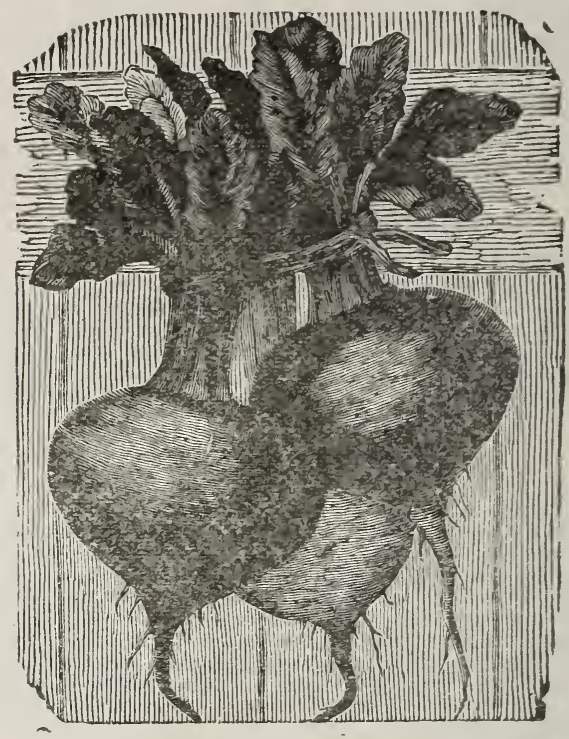

\section{Early Blood Turnip}

FXTRA EARLY EGYPTIAN-The earliest sort: turnipshaped, small, symmetrical, deep blood color. Pkt., 5c oz., 15ัc; $1 / 4$ lb., 40c; lb., \$1.35.

ECLIPSE-Makes rapid growth; top small, quality tine, larger than Egyptian, but not so deep a red in cowr. Pkt., sc; 0z., 15c; 1/4 1b., 40c; 1b., \$1.35.

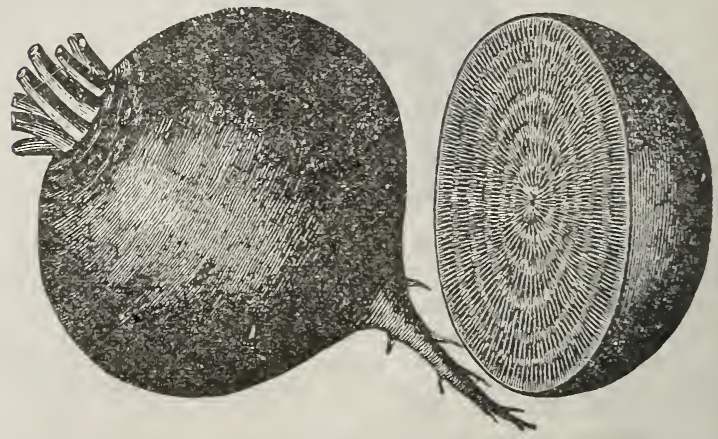

Detroit Dark Red Beet

DETROIT DARK RED TURNIP-A fine beet for bunching for market: tops exceptionally small and uniformly up-right. The roots are perfect turnip-shape, with smail tap-roots. One of the deepest red beets. Quality is of the finest; sweet and tender; best beet for home garden. Pkt., Jc; oz., 20c; 1/4 lb., 45c; lb., \$1.50.

SWISS CHARD OR SEA KALE BEET-Although little known in America, this vegetable is worthr of a place in every garden. The leaf and the leaf stems are the parts used and they are much superior to those of other beets to use as greens. Later in the season the broad, flat. beautiful, wax-like stems are cooked as a salad or pickled. Pkt., 5c; oz., 20c; 1/4 lb., 50c; 1b., \$1.60.

For Books on Gardening, see Page 74. 


\section{BEETS-Continued}

EARLY BLOOD TURNIP-Roots turnip shaped, deep crimson, tender and sweet. Pkt., 5c; oz., 15c; $1 / 4 \mathrm{lb}$. 40c; lb., \$1.35.

IMPROVED HALF-LONG BLOOD-An old and popular rict especially desirable for autumn and winter use. Pkt., כc; oz., 15c; 1/4 lb., 40c; 1b., \$1.35.

\section{STOCK BEETS}

IMPROVED GOLDEN TANKARD-We have for years nsisted that this was the best mangle grown, and each succeeding season strengthens us in the position we took when it was a comparatively unknown sort. We recommend it ungualifiedly as the best mangle by far for dairv farmers. Oz., 10c; $1 / 4$ lb., 20c; lb., 50c. Not postpaid, $5 \mathrm{lbs}$., \$1.75.

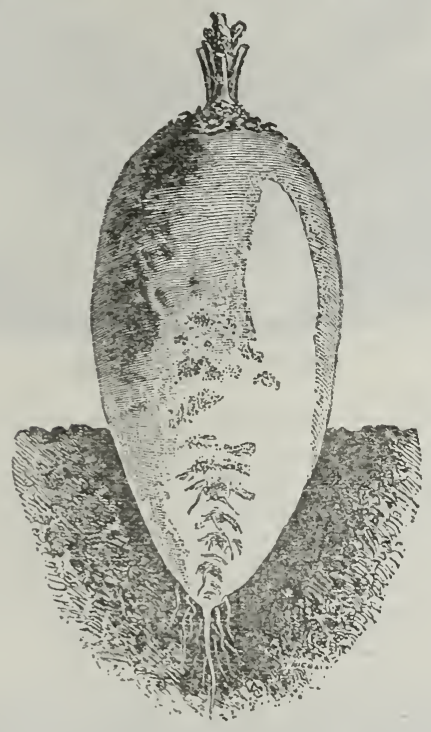

New IMangle, One-Half Sugar

NEW IIANGLE. HALF SUGAR-A new variety, very much more valuable for feeding purposes than the old sorts, it being very much richer. In addition to this, the size and form have been improved until it rields as much per acre as the best Mangles, and twice as much per acre (bulk or roots) as the rich sugar beet seed: is much easier handled, keeps better and is in every way most valuable to the farmer. Roots large, ovoid in form, very smooth. with few rootlets: light. pink or rose color, with small top. Oz.. 19c; 1/4 lb., 20c; ib., 5ac; express or freight, $51 \mathrm{hs}$, $\$ 1.75$.

IMPROVED NAMIMOTH IONG RED-Our stnck is a great improvement on the old variety: the roots are very large, uniformly straight and well formed: color deep red. roots solid and tops small; roots attain a large size, one being exlibited last year which weighed je pounds; produce an immense bulk and tonnage. Oz., 10c; $1 / 4 \mathrm{lb} ., 20 \mathrm{c}$ lb., 50c. Not postpaid, 5 lbs., \$1.75.

\section{Sugar Bests}

TLEIN WAULEBEN-A hardy and earlier grown variety, which is generally acknowledged to be the best to grow for the manufacture of sugar. Oz., $10 \mathrm{c} 1 / 4 \mathrm{lb} ., 15 \mathrm{c}$; ib., $45 \mathrm{c}$.

\section{BROCCOI.I}

Sow early in spring. Transplant and cultivate the same as cabbage. The broccoli is similar to the cauliflower They will produce heads in October and November, and should any plant not be forward enough for use before severe frosts, let them be removed to a light cellar, where they will head during the winter.

I.ARGE WHITE MAMMOTH-Pkt., 5c; oz., 35c; $1 / 4 \mathrm{lb}$, $\$ 1.00$.

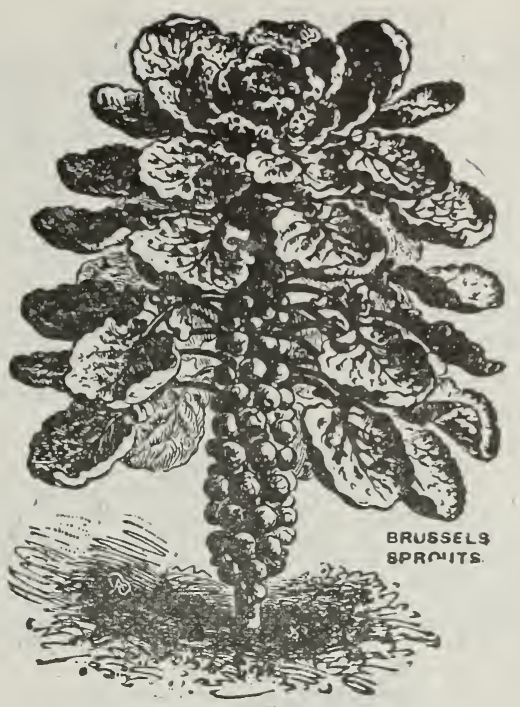

BRUSSELS SPROUTS

Cultivated for the small heads that grow in considerable numbers from the main stem. It is a delicacy mucn es teemed by some. Sow in seed bed middle of spring and transplant and manage as winter cabbage. Pkt., $5 \mathrm{c}$; $\mathbf{0 z}$. 20c; $1 / 4$ lb., 50c.

\section{Cabbage}

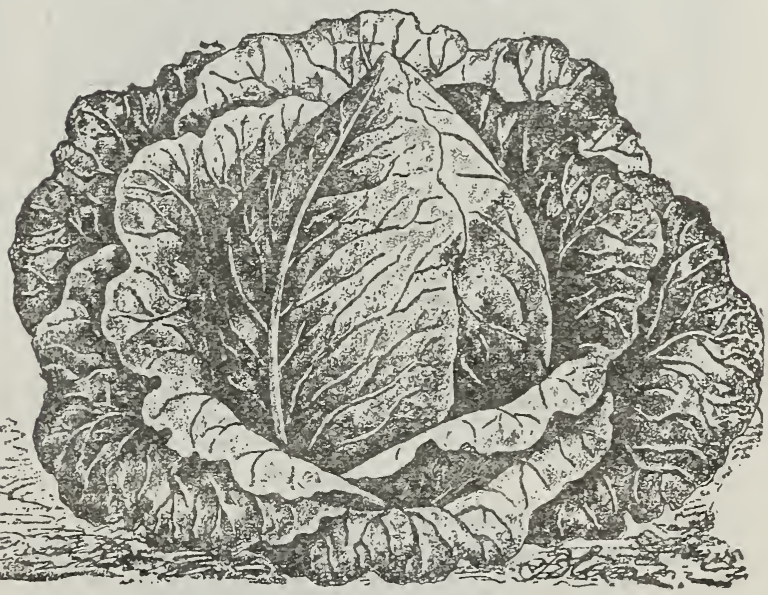

Early Jersey iw abefield

CULTURE-For early cabbages sow the seed in a hot bed in March or April, covering the seed from 1/4 to $1 / 2$ an inch deep and, when big enough, transplant to another bed As soon as the ground is in good condition transplant, outside, in rows 2 feet apart and 15 to 20 inches in the row. The soil should be mellow. rich and well drained. For late crop the seed can be sowed in a cold frame, or even in the open ground, and then transplanted in rows 3 feet one way and 2 feet the other, so as to be able to work with a horse and cultivator.

\section{First Early Cabbages}

EARLY JERSEY WAKEFIELD-The earliest and nardiest heading of extra early cabbages. Most gardeners depend upon it for the bulk of their extra early crop. Heads conical, very compact, solid and of excellent quality. The thick, stout leaves and comnact habit make it the best sort for very early setting. Pkt., 5c; oz., 20c; 2 oz., 35c; $1 / 4$ lb., 60c; $1 / 2$ ib., \$1.00; lb., \$1.75.

See Page 74 for Cultural Directions. 
CHARLESTON OR LARGE WAKEFIELD-Larger and little later than the Early Jersey Wakefield, but having the same general shape, except that it is less pointed good sort for market gardeners. Pkt., 5c; oz., 25c; 2 Qz. $40 \mathrm{c} ; 1 / 4$ lb., 65c; lb., $\$ 2.00$.

EARLY WINNINGSTADT-A desirable kind, having conical, solid heads; a sure header under almost any conditions, and keeps better than most early varieties. Fine and of excellent quality.
$1 / 4$ lb., 60c; lb., \$1.75.

HENDERSON'S EARLY SUMMER-About 10 days later than the Jersey Wakefield. 'The head is round, and the largest of the early kinds; can be set close in the row as the outer leaves are small. It remains long without bursting: is firm and of the best quality Pkt., Jc; oz. 20c; 2 oz., 35c; $1 / 4$ lb., 65c; 1b., \$2.00.

DANISH SUMMER BALLHEAD-The Danish Summer Ballhead Cabbage is taking the place anong the early varieties that the Danish Ballhead holds anong the later sorts. It is a second early, extremely hard, long-keeping and of superb quality, and on light soil does particularly well, being a sure header. It resembles the Winter Ballhead quite closely, excepting that it is smaller and slightly flat on top. It has traces of curliness on the outside leaves and delicate flavor that suggests Savoy blood. Color (1) rery small with fine ribs in the leaves. Pkt., 10c; 0z., 35c; 1/41b., 85c; 1b., \$2.75.

GLORY OF ENKHUIZEN-A comparatively new second early variety, very sure heading and of excellent quality. Plant of vigorous growth, with large, rather spreading outer leaves which are noticeably curved. Head globula

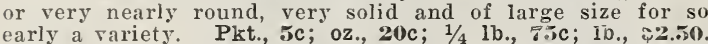

New Early Cabbage (Copenhagen Market)

This superb new Cabbage created quite a sensation at Fordhook Farms during the past season. One visitor who came from Illinois especially to visit the trial grounds said he could easily sell 40 pounds of the seed at $\$ 10$ per pound to his neighboring market gardeners. It is undoubtedly without a rival as the finest large round headed early Cabbage in cultivation. The type is thoroughly fixed, the heads maturing all at the same time (this being a great consideration to market gardeners, entailing less labor in harvesting the crop, and allows the ground to be cleared at the first cutting). The heads verage about 10 pounds each in weight, are very solid, with small core and of fine quality. It matures as early as Charleston Wakefield, and will give a much heavie yield per acre than that popular variety. The plant is short-stemmed, the heads being produced almost on the ground level. The leaves are light green, rather small, saucer-shaped, and always tightly folded. The plants, therefore, ean be set closer than is usual with varieties of similar size. Pkt., 10c; 0z., 60c; 1/4 lb., \$1.75.

ALL-HEAD EARLY-It is among the earliest of the large cabbages. It is fully one-third larger than the Early Summer. The deep flat heads are remarkably solid and uniform in color, as well as shape and size. It is very tender and of fine quality. Pkt., 5c; 0z., 20c; 1/4 lb., 6.tc lb., \$2.00.

\section{Late or Fall Sorts}

SELECTED LATE FLAT DUTCH-A low-growing variety; heads large, bluish green, round, solid, broad and flat on top; an excellent fall and winter variety and a good keeper, it is a sure header. Our stock has been grown from carefully selected heads, and we consider it superior to any other strain of Flat Dutch Cabbage on the

PREMIUM LATE DRUMHEAD-A sure heading sọrt, which in good rich soil will orow to an enormous size anu on poorer soils will give good-sized heads which are very compact, solid and of excellent flavor. Pkt., sc; oz., 20c; $1 / 4$ lb., 60c; $1 / 2$ lb., \$1.00; lb., \$1.75.

SUREHEAD - A popular sort for main crop; never 1ails to form uniformly large. solid heads, which are tender and of fine, sweet flavor. An excellent keever and a

DRUMHEAD SAVOY-Fine quality. Pkt., sc; oz., 15c; $1 / 4$ lb., 50c; lb., \$1.50.

ROCK RED-Best red sort, much used for pickling. Pkt., Jc; 0z., 20c; 1/4 lb., 7.c ; lb., \$2.00.

DANISH BALTHEAD, SEED-American grown. Pkt., 5c; 0z., 20c; $1 / 4 \mathrm{lb}$., (60c; lb., \$2.00.

\section{See Page 74 for Cultural Directions.}

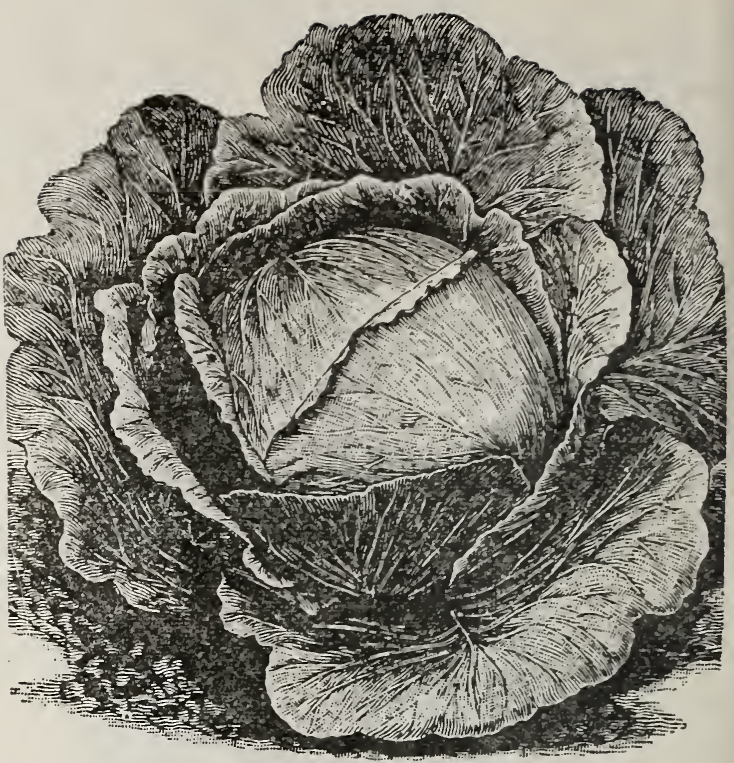

DANISH BALL HEAD.

CLOVER LEAF HOLLAND OR DANISH BALTHEAD

-Genuine Danish grown stock, short stems. Most re markable late cabbage yet produced. This is one of the hardiest cabbages in cultivation, and endures both frost and drought that would destroy other varieties. Plants very hardy and compact; leaves very smooth, but thick head of medium size, round and very solid, being the hardiest heading cabbage we know of, and of the very best quality. Matures quite late, keeps well and is considered by many the best cabbage to hold over for spring markets. Pkt., 10c; 0z., 25c; 1/4 lb., 85c; lb., \$2.75

DANISH ROUNDHEAD-An earlier, shorter stemmed, improved strain of the Danish Ballhead Cabbage. The heads are hard and very solid and mature about two weeks in advance of the Ballhead. They also average a little larger and heavier. The inner leaves are blanched almost pure white, are of sweet flavor, crisp and tender. It is less liable to blight and shows rigorous growth eren in the hot summer. Pkt., 5c; oz., 30c; $1 / 4 \mathrm{lb}$., 90c; 1b., \$3.00.

\section{Cauliflower}

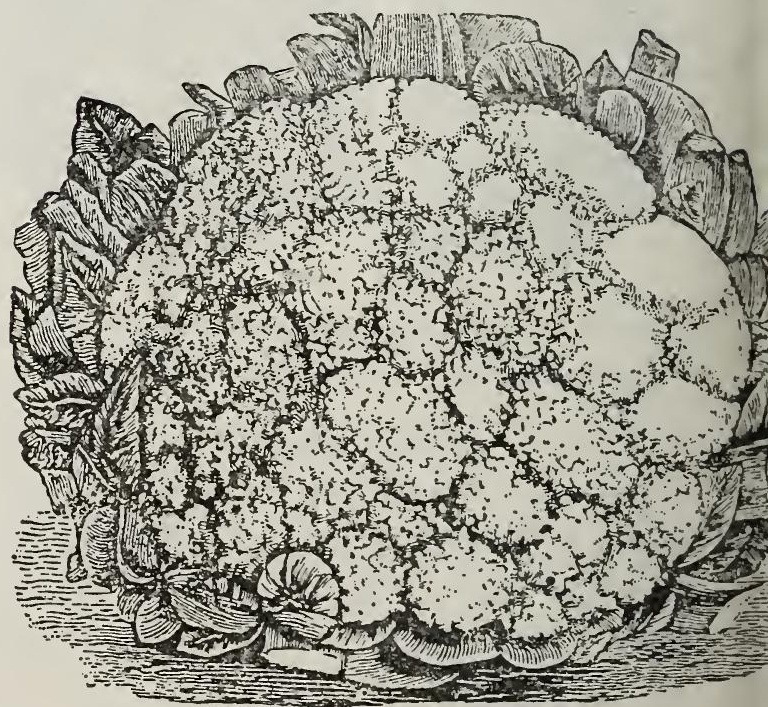




\section{CAULIFLOWER-Continued}

\section{Early Snowball}

CULTURE-The soil for cauliflower should be like that for cabbage, but is better if made richer than is ordinarily used for that crop. Give the plants thorough culture and keep free from worms, with insect powder. For late crop sow at same time as for late cabbage, and treat in the same manner. It should be borne in mind that cauliflower will not head up good in hot, dry weather, and hence the sowings should be so regulated as to bring it to maturity either before the hot summer weather sets in or nor until the cooler weather of the fall. If it receives at this time a liberal supply of water, the size and quality of the heads will be greatly improved. After the heads begin to form, draw the leaves orer and pin or tie them together to protect the heads from the sun and keep them white. The heads should be cut for use while the "curd" is compact and hard, as they soon become tough and bitter after they open and separate into branches.

CLOVER IEAF EARLY SNOWBAIL (Best Imported Strain) - This is an improved extra early strain of dwart, compact growth. Under favorable circumstances neariy every plant will make a fine, solid head of good size. It is valuable for both early and late. Pkt. 10c; $1 / 2$ oz., $\$ 1.25 ; 0 z ., \$ 2.25 ; 1 / 4$ 1b., \$8.00.

DANISH GIANT CR DRY WEATHER-Large leaved and large fiowering, with pure white compact heads. For open ground and forcing. Two weeks later than above, when planted at same time. Very resisting against unfavorable seasons and dry weather. Pkt., 10c; $1 / 2$ oz., $\$ 1.50$; oz., \$2.50.

EXTRA FARTY DIVARF FRFURT-Very dwarf, sure to head and one of the earliest. The heads are of good size, pure white, very solid, of excellent quality and delicate flavor. Pkt., 10c; oz., \$2.00.

AUTUMN GIANT-A distinct and valuable late variety. The heads are reasonably large, beautifully white, firm and compact, and, being well protected by foliage, remain for a long time fit to use. The plants should be started and transplanted early in the season to insure their full development. Pkt., 5்c; oz., 60c; $1 / 4$ lb., \$2.00.

\section{Celery}

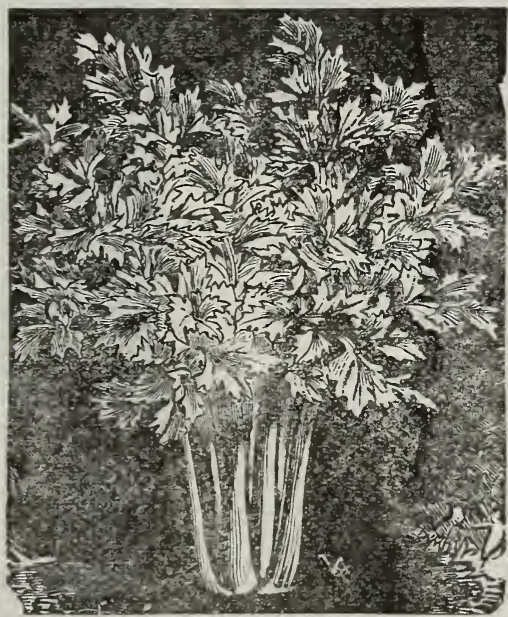

White Plume Celerg.

CULTURE-One ounce will produce about 3,000 plants and sow about 200 feet of row. Sow in light, rich soil, in shallow drills, and cover the seed lightly with finely sifted mold. Prick the seedling out into beds of very rich soil, 3 inches apart. Water freely and shade from the sun until established. When the plants are 5 to 6 inches high transplant to rows 3 to 4 feet apart, according to the variety, allowing 8 inches between the plants in the row. Cultivate freely and earth up to blanch the stems, pressing the soil firmly around the plant almost to the top, care being taken not to cover the tops of the center shoots. Remember that this crop well repays generous treatment.

WHITE PLUIME-French grown. A new variety; popular on account of its naturally white leaf stalks, which reanire less blanching than the other kinds. Tie the tops together and hill un the earth slightly. Its handsome. plume-like top is very ornamental on the table. It is quite early and a fin

GOLDEN SELF-BLANCIING-French grown. A variety somewhat resembling the White Plume, and, like it, requiring but little earthing to secure perfect blanching. It is of a rich, golden tint when ready for the table; vers handsome and of excellent quality. Pkt., 10c; 0z., 60c; $1 / 4$ lb., \$2.00.

GIANT PASCAL-A standard. sort for later or winter market; large fine stalks; when blanched, of a deep grolden yellow. Pkt., 5c; oz., 20c; 1/4 1b., 50c; 1b., \$1.50.

CELERIAC, OR TURNIP-ROOTED-Grown exclusively for its roots, which are turnip-shaped, very smooth, tender and marrow-like. The roots are cooked and sliced; used with vinegar they make an excellent salad. Pkt., J̄c; z., 20c; $1 / 4$ Ib., 60c.

\section{Carrots}

CULTURE-The carrot, like other root crops, delights in a sandy loam, deeply tilled. For early crops, sow in the spring as soon as the ground is in good working order for late crops they may be sown at any time until the middle $f$ June. Sow in rows, about 15 inches apart, thinning out 3 inches between plants. One ounce to 150 feet of drill: $3 \mathrm{lbs}$. to an acre.

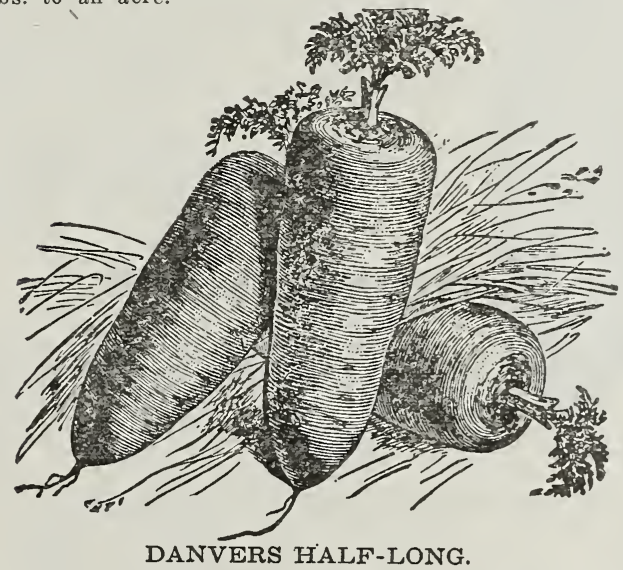

EARII ECARLET FORN-A rery early variety. Recommended for the market and family garden. Texture fine; very delicate in flavor. Pkt., 5c; 0z., 15c; 1/41b., 35c; 13., \$1.10.

CHANTENAY-As a table variety it is first class; in shape it is larger than the Scarlet Horn, and also broader at the shoulder. The flesh is of a beautiful rich orange color and of finest quality. Elt., 5c; 03., 15c; 1/4 1b., 35c; lb., $\$ 1.00$.

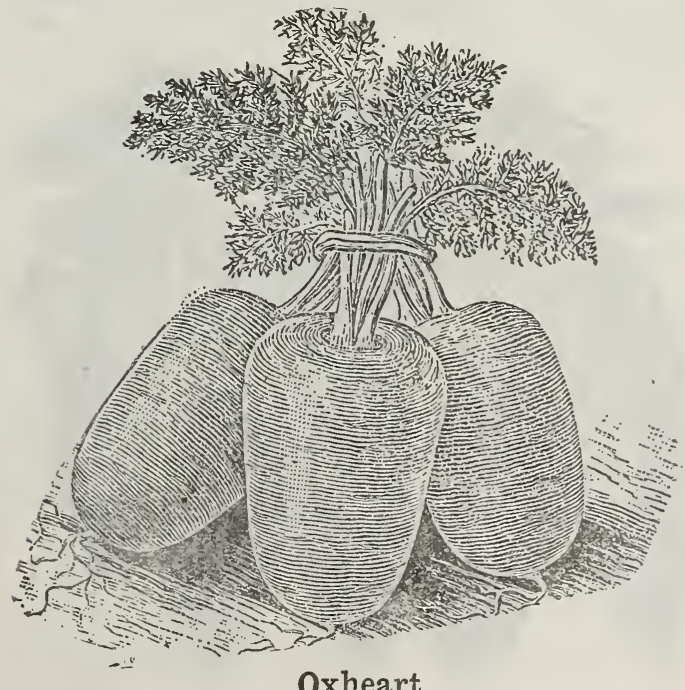




\section{CARROTS-Continued}

GUERANDE, OR OX HEART-A thick carrot, five or six inches long and very blunt at the lower extremity. It grows very rapidly and the root attains a weight of more than a pound. It is tender and of good flavor, and a variety that we can recommend to all market gardeners. Pkt., 5c; oz., 15c; 1/4 b., 35c; lb., \$1.00.

IMPROVED DANVERS HALF-LONG-A first-class carrot for all soils; in form midway between the Long Orange and Short Horn. The root is of a rich, dark orange color and grows very smooth and handsome, 20 to 30 tons per acre being not an unusual crop. Pkt., 5c; oz., 15c; $1 / 41 \mathrm{~b} ., 35 \mathrm{c} ; 1 \mathrm{~b} ., \$ 1.00$.

LONG ORANGE IMPROVED-Very desirable for garden or field culture. Pkt. 5c; oz., 15c; $1 / 4$ lb., 35c; lb., \$1.00.

\section{STOCK CARROTS}

LARGE WHITE BELGIAN-Grow's one-third out of the ground; root pure white, green above ground, with small top; flesh rather coarse; the roots, on light, rich ground, grow to a large size, and are extensively grown for stock feeding. Pkt., sc; oz., 10c; $1 / 4 \mathrm{lb} ., 30 \mathrm{c} ; \mathrm{lb} ., 8$ : $\mathrm{c}$.

MASTODON CARROT-The flesh is white, crisp, solid and very sweet in flavor. It is a vast improvement on the white and green Belgian sorts, which have been favorites in the past, as it is not only much more productive, "a rastly easier to handle. Oz., 10c; $1 / 4$ Ib., :30c; 1b., 85c.

YELLOW GIANT-This new earrot is half-long variety, with an immense broad shoulder. The carrot penetrates less than one-half the depth into the ground. The impor tance of this point should not be overlooked, as it saves about one-half the expense in the harvesting of the crop. The color is a bright vellow, and is perfection for giving the proper color to your butter. Oz., 15c; 1/4 1b., 30c; lb., 855 .

\section{Cucumbers}

For very early cucumbers, sow the first of Aprll in a hotbed upon pieces of sod (grass side down), so that they can be readily transplanted to the open ground, in rich soil, when danger of frost is over, or protect by handglasses. For early use, plant, if the weather has become settled and warm, in hills about four feet apart each way; thin out to four of the strongest plants to each hill. after all danger from insects is over; they succed best in warm, moist, rich, loamy soil; continue planting at intervals for a succession. The cucumbers should be gathered when large enough to use, whether required or not: if let to ripen it destroys their productiveness. For pickles, plant from June until the middle of July.

EARLY CLUSTER -A short, prickly variety; usually prows in clusters. Is a prolific bearer, and except the Early Russian, is the earliest sort; flavor excellent. Pkt. 5c; oz., 10c; 1/4 1b., 25c; 1b., 75c.

COOL AND CRISP-A strain of the White Spine, but longer and more cylindrical; very early and exceedingly prolific While it is esteemed most highly as a pickling sort, it is one of the very best for slicing, being tender, crisp and of fine flavor. Pkt., 5c; oz., 10c; $1 / 4$ 1b., 25c; 13., SOc.

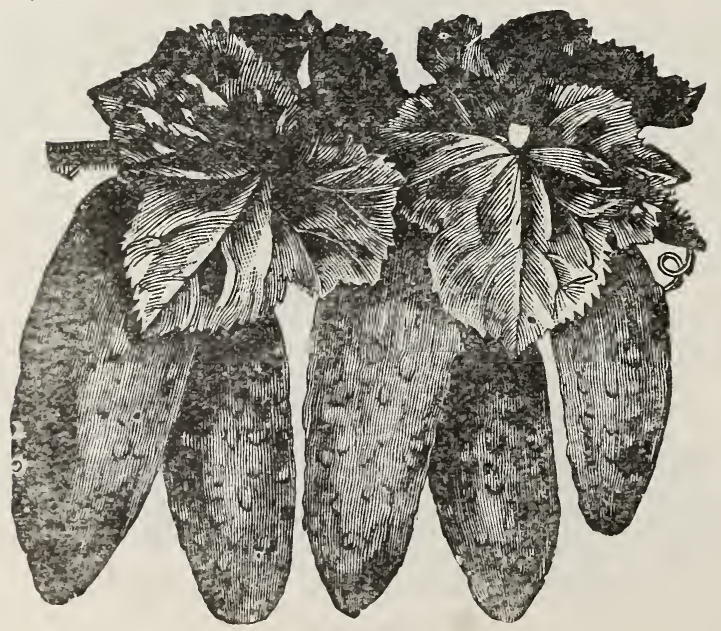

EARLY SHORT GREEN, OR EARLY FRAME-A vigorous and productive variety, producing fruit of medium size and regular form; flesh crisp and tender; excellent for the table or pickling when small. Pkt., 5c; oz., 10c; $1 / 4$ lb., $25 \mathrm{c}$; 1b., $75 \mathrm{c}$.

EARLY WHITE SPINE-One of the best sorts for table use; fruiting carly and abundantly; fruit uniformly straight and handsome, light green, with a few white spines. Pkt., 5c; oz., 10c; 1/4 lb., 25c; lb., 7.sc.

THE NEW DAVIS PERFECT-This cucumber has an ideal shape and a beautiful dark green color, which it holds extremely well during the slicing season. Its eating qualities are unsurpassed, both because of its fine flavor and its small number of seeds which, during the slicing period, are so small and tender as to be practically un noticed; believe it will produce more fruit than any other variety ever grown. Pkt., 10c; oz., 1.,c; $1 / 4$ lb., 40c; lb., $\$ 1.25$.

LONG GREEN -A popular variety for pickling and slic. ing. Large pkt., 5c; oz., 10c; $1 / 4$ ib., 2.5c; lb., 80c.

BOSTON PICKIING-This variety is very popular with our gardeners to grow for pickles. Fruit smal, smooth, bright green and good quality. A great producer. Pkt., ic; oz., 10c; 1/4 lb., 25c; 1b.; SOc.

WEST INDIA GHERKIN-This variety used exclusively for pickling, a distinct specias from the common cucumber It is a vigorous grower and consequently should be planted 6 feet apart. The fruit is rery small, almost round and closely covered with spines. Pkt., 5c; oz., 20c; 1/4 lb., 60c.

JAPANESE CIIMBING-A sort of pole cucumber, its name being due to its tendency to climb and bear its fruit up from the ground, if afforded support; fruit large and thick. Pkt., 5c.

\section{Sweet Corn}

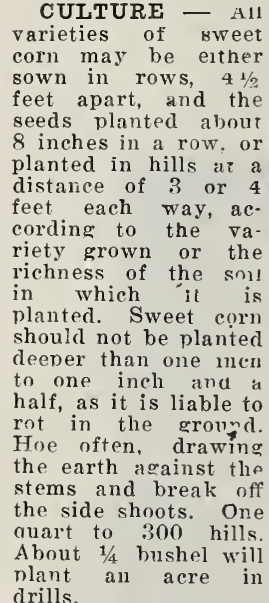

First Early

Varieties

PEEP O' DAY NEW SWEET CORN -Ten days earlier than any other; sweet, early, productive. You will not be dis. appointed in this new sweet corn. Recently introduced. Has pleased every. one who has tried it. For flavor, sweetness and productiveness it is ahead of any other early white sweet

corn. addition to our list of corn for our short western summers. Lh.. 2., postpaid, express or freight; 1b., 15c; 10 lbs., $\$ 1.25$.

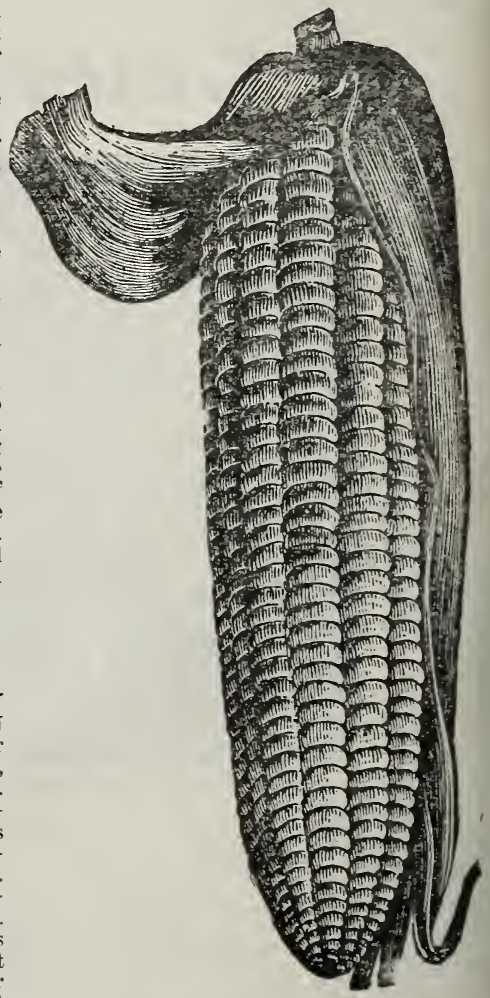


GOLDEN BANTAM-Of extreme hardiness, this can be planted earlier than any other true sweet corn, and will then produce the earliest supply of ears for the table. Planted later it does not develop so quickly as Early lordhook or Cory, but is vastly superior in rich, sweet flavor. By repeated plantings, Golden Bantam alone will furuish a constant supply of the finest ears throughout the entire season. The stalks grow from three and onehalf to four feet in height and produce one or two good ears ou each stalk. The ears are about six inches in length completely filled with eight rows of golden-yellow grains, extending to the rounded tip. The flavor is exceptionally rich and sugary, "the sweetest of all.", Plrt., ic; lb., 25c postpaid, express or freight; lb., 15c; 10 lbs., $\$ 1.25$.

EARLY MINNESOTA-A splendid and standard variety; cars are good size, the grains sweet and tender. Lb., 2.5c postpaid, express or freight; lb., 15c; 10 Ibs., $\$ 1.00$.

WHITE COB CORY-An improvement on the Red Cobbed Cory, as well as being equally early. 'The ears are larger and it has further advantage of having both a white cob and a white grain. A splendid market garden variety and excellent for the table. Pkt., 5c; lb., 25c postpaid, express or freight; Ib., 15c; $10 \mathrm{lbs} ., \$ 1.00$.

\section{Medium Early Varieties}

FERRY'S NEW FARTY FVERGREEN - As is well kuown, the famous Frergreen Sweet Corm originated over 20 years ago, but while it is the best variety of late sweet corn, no effort has ever been made to improve it in earliness until now. In the New Early Evergreen we have a selection possessing every good quality of Stowell's Evergreen, and resembling it in every respect, except that the stalk is about one foot shorter, more closely jointed, and that it will mature for market 10 to 14 days earlier. It is certainly a valuable addition to the corn list, and we advise our customers to try this variety. Pkt. 5c: lb., 25c postpaid, express or freight; Ib., $15 \mathrm{c}$; $10 \mathrm{lbs} ., \$ 1.50$.

WHITE MEXICAN-This new variety of recent introduetion is four or five days earlier than the White Cob Cory and has all the delicious sweetnes of Black Mexican, which before the introduction of this new white corn was said to be the sweetest of all sweet corns. It is a grand acquisition for the market gardener, as well as for the home planter. Lb., 25c postpaid, express or freight; Ib. 15c; 10 lbs., $\$ 1.25$.

\section{Late Varieties}

STOWELL'S EVERGREE -The standard main crop variety. Large, well formed ears, deep grained; very sweet and sugary. It is hardy and productive and altogether the best kind for general use. Pkt., 5c; lb., 25c postpaid, express or freight; lb., 15c; $10 \mathrm{lbs} ., \$ 1.00$.

\section{Field Seed Corn}

A few years ago very little corn was grown in this country and if anyone had made the asserion tnat 50 bushels or more of corn would be grown per acre he would have been laughed at. Different parties have told us this year that they had 60 bushels per acre. Through experiments and tests carried on for a number or years, this year I have three varieties of acclimated home-grown corn to offer. It has been proven that home-grown, accnmated corn ripens from two to three weeks earlier tnan eastern corn. Therefore, if you wish to grow corn vu maturity it is essential that you use home production. I you wish an ensilage or fodder corn, some of the later eastern grown varieties produce more per acre. Last year was a poor corn year here, and the demand was so great that we were simply unable to fill orders. At the present time the prospects are good for fair quantities of varietiest listed, but to insure delivery it is best to place orders eearly.

For Books on Gardening, see Page 74.

MINNESOTA KING (Home Growu) - We regard this corn in some respects as the most valuable early corn for the vicility. It seems to possess a faculty of growing right aiong allu making a crop during weather and under conditions that would ruin other varieties. In appearance the Minnesota King is remarkably distinct, be ing a half yellow dent, the keruels are very broad and are a rich golden color. Lb., 20c; 3 lbs., 50c postpaid. By express or freight, 10 lbs., (iOc 100 lbs., \$3.50.

NORTHWESTERN GOLDEN DENT (Home Grown) - This corn is truly a home product, having been brought up to its present standard by an enterprising farmer in Northern Idalo. Many years ago he brouglit with him a yellow dent corn which he planted. It proved to be too late a variety and very little matured. The following year he procured a very early golden dent corn and planted a hill of it, then a hill of the yellow dent. The result has been a beautiful Golden Dent that matures and yields well here. Pe: lb., 20c, postpaid. By express or freight, 10 lbs., 75c; 100 lbs., \$4.51).

FLINT YELLOW EARLY EIGHTROWED, OR EARLY CANADA-The great Yellow Flint Corn-the corn for the extreme north. The greatest of all the Flint varieties. Earls long, of rich yellow color. Will prove to be of the greatest value to the farmers of the far north. Ripens earlier than any of the Flints. Don't fail to try it if you want a big yielding Flint Corn. Per lb., 10c; 10 lbs., 75̃c: 100 lbs., $\$ 4.50$

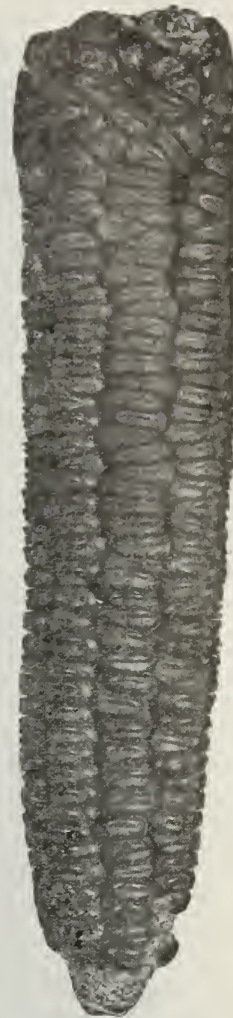

MINNESOTA KING

\section{FODDER CORN-Eastern Grown}

PRIDE OF THE NORTH-(Yellow Dent)-This is a standard early variety of corn in the east, but is not sure to mature here; in fact, we have been unable to procure any home-grown seed. From the fact that it produces a large amount of fodder and being early enough to get in proper condition for ensilage, it has taken the lead over all other corns for this purpose. By express or freight, 10 lks., 60c; 100 lbs., \$3.50.

\section{Pop Corn}

WHITE RICE-The best corn for popping and for the general market; early, white pointed kernels. Lib., postpaid, 25c; express or freight, 10 lbs., $\$ 1.00$.

\section{CRESS}

A delicate, pungent salad plant, very agreeable alone or mixed with other salads. Entirely distinct from common cress, thriving only where its roots are submerged. Sow the seed thinly along the banks of any shallow stream early in the spring. It will increase rapidly if the conditions are favorable, and reappear every spring with no further attention.

TRUE WAT'ER-Per oz., 30c; 1/4 lb., $\$ 1.00 ; 1 / 2 \quad 1 b$. $\$ 1.75 ; 1 b ., \$ 3.25$.

CRESS, OR PEPPER GRASS-The leaves, when young, have a warm, pungent taste, and are used as a salad, either alone or mixed with other salad plants. The seed germi. nates quickly and the plants grow rapidly. As they are milder and more tender when young, the seed should be sown at intervals of 10 to 15 days, making the first sowing as soon as the ground can be prepared. May be cut several times.

CURLED-The best garden variety. Per oz., 10c $1 / 4$ lb., 25c; 1b., 60c. 


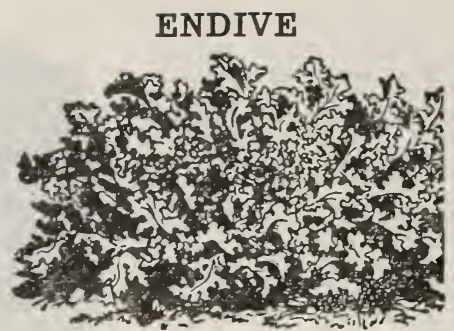

ENDIVE-A desirable salad when bleached by exclusion from the sun. Plst., 5c; 0z., 15c; 1/4 lb., 40c; 1b., \$1.25.

\section{EGG PLANT}

CULTURE-Sow in hotbeds very early in the spring; thin them out as soon as big enough to be handled to 3 or 4 inches each way, and transplant to 2 or 3 feet apart in very rich, warm ground. Do not plant them outside till nights are real warm, as the least frost will, if it does not kill them, check the growth, and it will take two or three weeks before they get over it. Hoe often and hill up gradually till they hlossom. One olnes th 1 inn nlants.

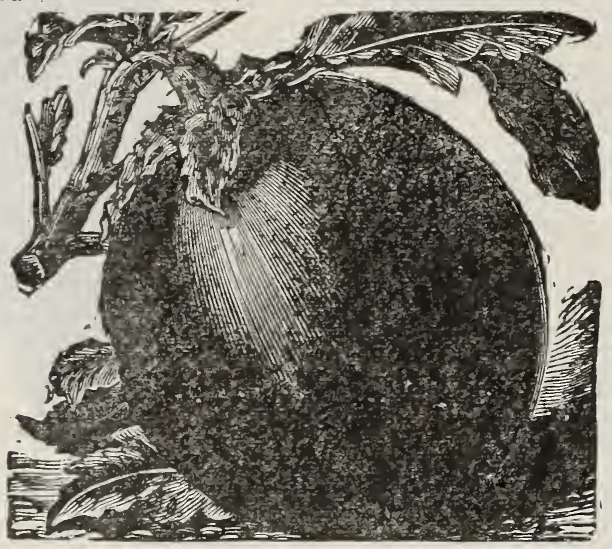

Improved New York Purple Egg Plant

BLACK BEAUTY-This beautiful egg plant is 10 days earlier than the New York Improved. The fruit is broad and thick, of most attractive form and does not fade or change to a lighter color at the blossom end. The fruits set freely and are ready for market early, so the crop can be gathered before danger of frost. Per pkg., 10c; 1 oz., $40 \mathrm{c} ; 1 / 4 \mathrm{lb} ., \$ 1.40$.

NEW YORK TMPROVED-This is a standard variety, both for market and home garden; a favorite everywhere. Our stock is extra selected, direct from the best growers in New Jersey. Per pkg., 5c; 1 oz., 40c; 1/4 1b., \$1.25.

\section{GARLIC}

Used same as onions. Sets, per lb., 20c: postpaid, 30c.

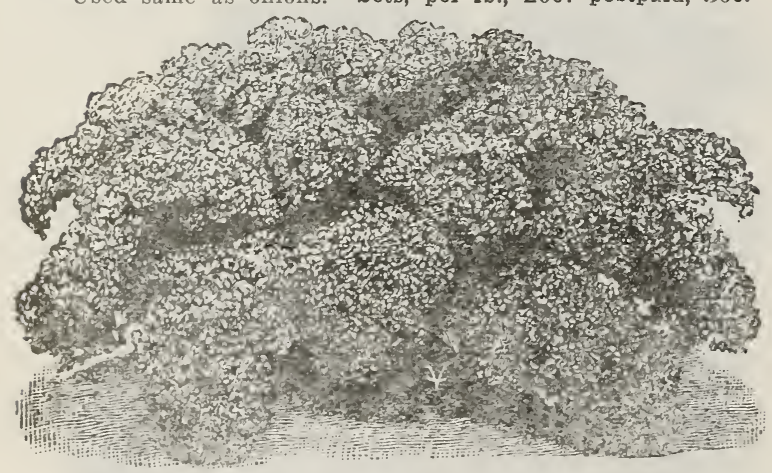

\section{KALE OR BORECOLE}

Kale, or Borecole, is a kind of cabbage that does not form a close and solid head. but a cluster of beautifully curled or wrinkled leaves, that are tender and of excellent flavor. It requires the same treatment as cabbage, and is very hardy, being improved by frost.
Kale

TALI GREEN CURLED STOTCH-Produces an abundance of dark green, curled leaves. Very hardy. The leading variety. Pkt., 5c; oz., 15c; 2 oz., 20c; 1/4 1b., 30c.

DWARF GREEN CURLED OR GERMAN GREENS-A dwarf variety, finer and more compact than the Scotch. Can be sown in the fall, for use early in the spring. Pkt., 5c; ofi., 15c; 2 oz., 20c; $1 / 4$ lb., 30c.

THOUSAND HEADED KALE-The great demand for this wonderful forage plant proves it to. be the most valuable green feed for Pacific coast dairy and stockmen; en dorsed by agricultural colleges and government stations. Postpaid, 1 oz., 10c; 1/4 lb., 20c; 1 lb., 60c.

\section{KOHL-RABI}

\section{Or Turnip-Rooted Cabbage}

The Kohl-Rabi is a vegetable intermediate between the cabbage and turnip, and combines the flazor of each. The edible part is a turnipshaped bulb, formed by the enlargement of the stem. When used for the table this should be cut when quite small, as it is then very tender and delicate, but if allowed to reach its full size it becomes tough and stringy.

FARLY WUTTE VIENNA -The earliest and best for forcing: very tender; excellent for table use. Pkt., 5c; oz., 20c; 1b., \$60.

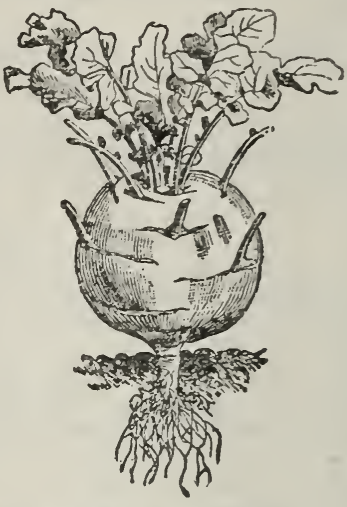

\section{LETTUCE}

CULTURE-The early sowing may be made under glass, in January and February, keeping the plants thin and admitting plenty of air every fine day. For a succession, outside, sow every two weeks as soon as the ground is open, in drills one foot apart, covering the seeds about one-quarter of an inch deep and thimning out to 6 or 8 inches in the row. For a cut salad sow thicker and do not thin out. They do best in rich and moist soil. One ounce to 3,000 plants.

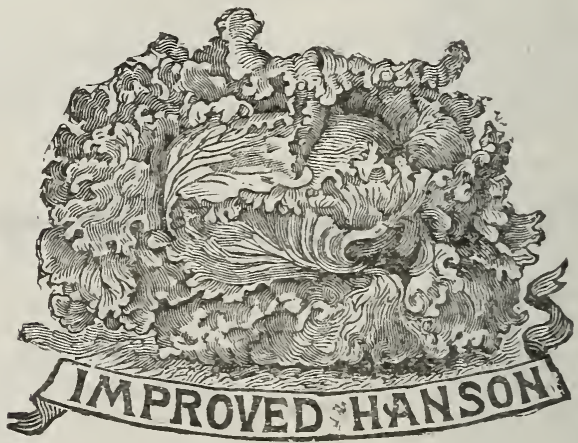

\section{Early and Forcing Varieties}

MAY KING-The plants are of quick growth, practically all head and extremely handsome. From early spring plantings in the open ground they grow quickly to a diameter of six to seven inches with the brnad, licht green outer leaves folding closely about the round solid head: in cool weather the edges of these outer leaves are lightly tinged with brown. The inner leaves (practically the entire head) are blanched to a rich golden yellow and have a specially fine, rich, buttery flavor. The round solid heads are so firmly folded that they can be shipped to distant markets and arrive in good condition. We recommend repeated plantings of this new early ra. riety in the spring, and again during August and September for fall use. Pkt., 5c; oz., 10c; $1 / 41 \mathrm{~b} ., 30 \mathrm{c} ; 1 \mathrm{lb}$. \$1.00. 
BIG BOSTON-It is an early variety of Head Lettuce either for forcing or open ground. It forms large, solid heads of a good light green color. and is very slow to go to seed. The leaves are beautifully marked and blistered and very crisp and tender and of excellent flavor. By these blistered leaves it distinguishes itself from any other kind of lettuce now grown. The shape of the head resembles somewhat the Hanson, but is more oblong. This stock is grown expressly for gardeners' use. Buy from us and get the true stock. Pkt., 5c; 0z.. 10c; $1 / 4$ lb., 30c; 1b., \$1.00.

GRAND RAPIDS (Seed Black) - $\lambda$ s a lettuce for green house forcing, this variety undoubtedly stands at the head of the list. being of quick growth, little liable to rot islu standing for some days after being ready to cul. 'The plant is upright and forms a loose head or cluster of large, bright leaves, slightly crimped and blistered and rather thin. The leaves do not wilt quickly after cutting, so that the variety will stand shipping long distances better than most sorts. Pkt., 5c; 0z., 10c; $1 / \frac{1}{4}$ lb., 30c; 1b., \$1.00.

\section{Loosehead or Cutting Varieties}

PRIZEHEAD (W. S.)-Large, loose-headed sort, the leaves are tinged witl brown, very heavy. Pkt., Ec; oz., $10 \mathrm{c} ; 1 / 4$ lb., 30c; 1b., \$1.00.

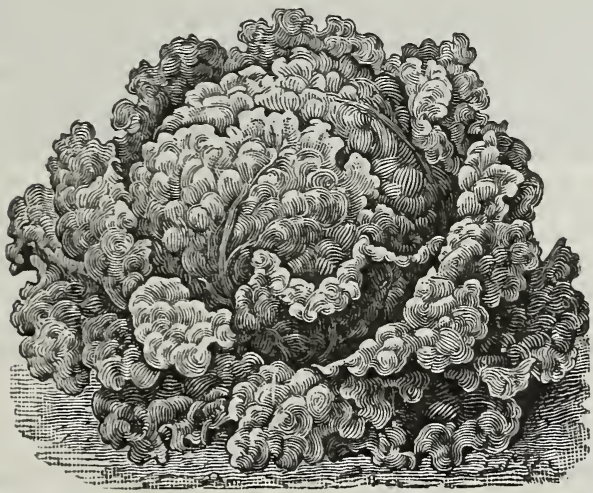

EARLY CURLED SILESIA-One of the best curled varieties, either for forcing or for early sowing out of doors. Very popular with market gardeners and private planters. Pkt., 5c; oz., 10c; 1/4 lb., 30c; lb., \$1.00.

BLACK-SEEDED SIMPSON-Very large, loose heads of curly, golden-yellow leaves, which are thin and tender. It stands summer heat splendidly and is valued for frame culture. Pkt., 5c; oz., 10c; 1/4 lb., 30c; lb., \$1.00.

\section{Butterhead Lettuce}

SALAMANDER-A bright green attractive summer variety, producing large, solid heads, very smooth, tender leaves, and of the finest quality. Pkt., 5c; oz., 10c; $1 / 4$ 1b., 30c; 1b., \$1.00.

\section{Solid Crop Head Lettuce}

IMPROVED HANSON-We have a very tine stock of this variety, and can recommend it as one of the best on our list. It is a fine heading variety of the largest size; solid, sweet, tender and crisp throughout, and en-tirely free from any bitter taste; for home use one of the best lettuces known. Pkt., 5c; zz., 10c; 1/4 lb., 30c; lb., \$1.00.

ICEBERG-Has an unusually solid head. The white main ribs of the leaves curve toward the center, which keeps the interior thoroughly bleached. It is quickly grow. ing and always crisp and tender, whether propagated in early spring or in the hot days of summer. Pkt., 5c; oz., 10c; $1 / 4$ lb., 30c; lb., \$1.00.

CRISP-AS-ICE-It is a beautiful lettuce of the cabbage type. The solid heads are of rreat size, and leaves so tender and brittle as to have suggested the name bestowed upon it. The head has a rich, yellow heart. The leaves are thick and glossy, somewhat curled, of a good and attractive green color, variegated with bronze. This lettuce cannot be overestimated or overpraised for nome use in spring and summer. Pkt., 5c; oz., 10c; 1/4 lb., 30c; lb., $\$ 1.00$.

PARIS WHITE COS-The Cos lettuce differs entirely in shape from other varieties, the head being elongated and of conical form, eight or nine inches in height and five or six inches in diameter. The outer coloring of this variety is yellowish green. To be had in perfection it requires to be tied up to insure blanching. Millions of this variety are annually grown to supply the markets of London alone. This variety is the best of all Cos varieties. All of th foregoing lettuce, unless otherwise quoted: Per pkt, sc; oz., 10c; $3 / 4$ lb., 35c; $1 / 2$ lb., 5.5c; 1 lb., \$1.(00.

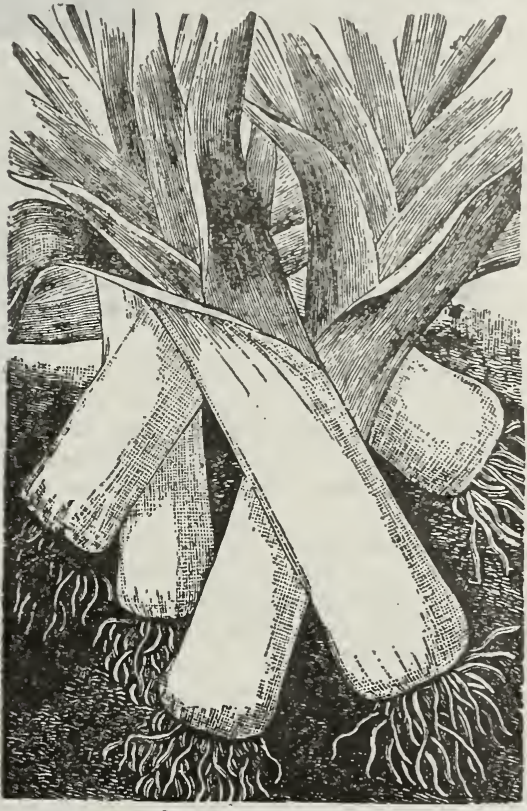

\section{LEEK}

One ounce will sow 100 feet of drill.

LARGE LONDON, OR SCOTCH FLAG-This leek is reported more delicate than the onion for soup, etc. Sown in seedbed middle of spring: when the plants are three or four inches high, transplant them into rows wide enough apart to admit the hoe between them. With good culture they may be grown five or six inches in circumference. Pkt., 5c; oz., 15c; 1/4 lb., 45c; lb., \$1.30.

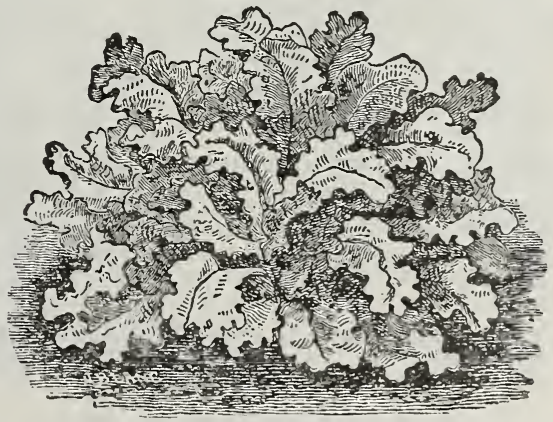

\section{MIUSTARD}

Used alone as "greens" or with cress as salad. Sow any time in the spring, in rows, and thin out as necessary.

SOUTHERN GIANT CURLED-We offer a very fine strain of the true curled leaf. Pkt., 5c; oz., 10c; $1 / 4 \mathrm{lb}$., 20c; 1b., 60c.

WHITE ENGLISH MUSTARD-Leaves mild and tender when young; seeds yellow. Pkg., 5c; 0z., 10c; $1 / 4$ lb., 15c; $1 \mathrm{lb} ., 35 \mathrm{c}$. 
With intelligent care and good spawn, mushrooms can be made to pay handsomely. They can be successfully grown in a dry cellar, inder the benches of a greenhouse, or in sheds where the temperature can be kept from 50 to 60 degrees through the winter.

\section{LAMBERT'S PURE CULTURE}

- $A$ new kind of spawn, without a doubt the best; inuch superior to the common English. It comes in bricks, weighing about 20 ounces.

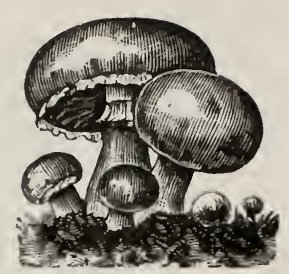
Treken up into pieces the size of a walnut and put inte the bed one foot apart each way. White, cream, brick, 25c; postpaid, 35c; by express, not prepaid, 5 bricks, \$1.00.

Illustrated book on Mushroom Culture, containing the latest methods of raising, preserving and cooking mushrooms, 15c, pstpaid.

\section{Musk Melon}

CULTURE-Musk melons do best on newly broken sod or prairie land, or on soil prepared by plowing under a crop of rye or wheat in the spring. The seed should not be planted until the soil has become thoroughly warmed, about corn-planting time. Plant five or six seeds to the hill, in hills four to six feet apart. Rich soil or wellrotted manure should be used in the hills; when the plants are of sufficient size, thin out to three vines to the hill. After the vines have grown about a foot long, pinch off the ends: this will cause them to become stronger and to throw out branches.

\section{Green-Fleshed Varieties}

HACKENSACK EXTRA EARLY IMPROVED-A selecimprovement on the old Hackensack, and tion from and an improvement on the old Hackensack, and 10 days earlier; one of the finest for market gardeners; quality pefect. Pkt., 5c; oz., 15c; 1/4 lb., 35c; lb., \$1.00.

EARLY PROLIFIC NUTMEG-Fruit of medium size, slightly ribbed, globular. Skin dark green, becoming vellow when overripe, and nearly covered with broad, shaljow netting. rkt., 5c; oz., 15c; 1/4 lb., 35c; lb., \$1.00.

BANANA-Melons very slender and two or three feet long. A very fragrant variety, and if not picked until thoroughly ripe, of very good quality. Its flesh and flavor, as well as its shape, remind one of a great luscious banana. Pkt., 5c; oz., 25c.

LARGE YELLOW CANTELOUPE-Although there are several varieties frequently substituted for this sort, we several varieties frequent find it very popular with all who have a distinct tye, fruit is large, oblong, slightly ribbed have tried it. The fruit is large, oblong, slightly riber very sweet, crisp and delicious. Pkt., 5c; oz., 25c.

PEACH OR GARDEN LEMON-The fruit is about the PEACH size of a large peach, oval shaped and of a bright orange
vellow color, somewhat russetted. When it first ripens it is quite hard and has very little flavor, but they soon become mellow, not sweet, and have a rich flavor. For sweet pickles, pies or preserving they are superb. Pkt., 5c: oz., 25c.

BURRELI GEM-Burrell's Gem has a tough, thin rind, well arched ribs, covered with a closely interlaced gray netting; shape elongated, being about $41 / 2$ inches in
diameter by 6 inches long, flesh of a reddish orange, very thick, fine grained and spicy, seed held firmly in a triangular cavity. This is the secret of a good shipping melon. If the seeds shake loose easily a melon will quickly decay. Pkt., 5c; oz., 15c; 1/4 lb., 35c; lb., \$1.00.

POLLOCK'S RUST-RESISTANT-Mr. Pollock originated the melon selcting seed from a plant the melon bearing his name by selcting seed from a plant destroyed. This noint has been observed in selecting stock seed until the melon, while not being perfectly rustproof, is practically so. The main difference between 11 and is practically so. The main or orinal, or style, Rocky Ford is more uniform and the original, or old style, Rocky Ford is more uniform and
on most land runs entirely to standard size crates. Pkt., 10c; oz., 20c; 1/4 lb., 40c; lb., \$1.25.
THE CELEBRATED

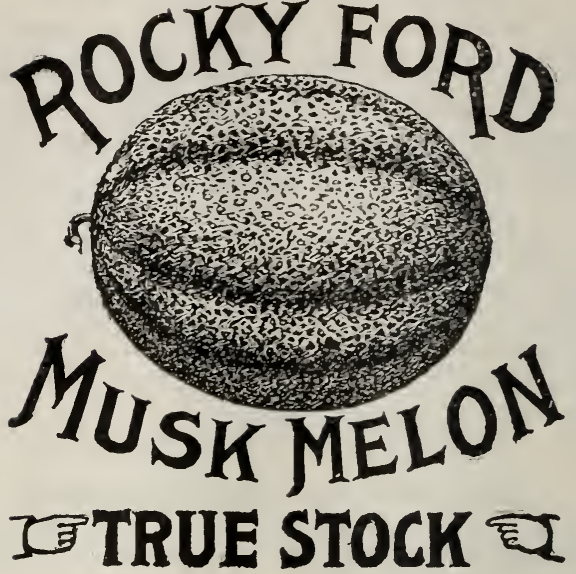

THE ROCKY FORD MUSK MELON-Is a new and most valuable introduction, and has attained in an incredibly short time a national reputaion. It is of the Netted Gem type, oval in shape, averaging from four and one-half to five inches in length, of a delicious flavor, very fine and smooth grained flesh, of a light green color througnout when ripe. From the district in which it has been for the past several years so extensively grown, Rocky Ford, Colorado, and from which point these melons are shinped in their season by the carload to nearly every station in the United States, till the name Rocky Ford has become a synonym for excellence in cantaloupes. Pkt., 5c; oz., 15c; $1 / 4$ lb., 30c; lb., 90c.

\section{Salmon-Fleshed Varieties}

EMERALD GEM-This is a new variety of excellent quality; it is of medium size. The skin, white-ribbed, is perfectly smooth and of a deep emerald green color. ine flesh is thick and of a deep salmon color, and ripens to the green rind. It is peculiarly crystaline in appearance, and so very juicy and rich that it almost drops to pieces when dipped out with a spoon. The flavor is very sweet and luscious. The vines are hardy and very prolific, and the melons mature extremely early. Pkt., 5c; oz., 15c; $1 / 4$ lb., 30c; lb., 85c.

OSAGE OR MILLER'S CREAM-The great popularity which this melon has attained is due mainly to its peculiar luscious, spicy flavor and its perfect shipping qualities. The skin is very thin, of a dark green color and slightly netted. The flesh is of a salmon color, remarkably sweet, extremely thick, and delicious to the rind. It is also very productive. It is a remarkable keeper, and will stand shipping. Pkt., 5c; oz., 15c; $1 / 4$ lb., 30c; lb., d5c.

PAUL ROSE-A new variety. A successful cross between the Osage and Netted Gem. It combines the sweetness of the former with the fine netting of the Gem and is even a better shipper than that variety. The melons grow uniform in shape and size. The flesh is remarkably thick, making the melons very solid and heavy, and of a beautiful salmon or orange color; deliciously sweet and melting. Pkt., 5c; oz., 15c; 1/4' lb., 30c; lb., 85c.

Our Rocky Ford Canteloupe Seed is from two fields that took the two first premiums at the Colorado State Fair.

Gardens!-Please write for prices on large orders. 


\section{Water Melon}

FORDHOOK EARLY - An extra early water melon of large size. Attain an average weight of 30 pounds. The rínd is tough, making it desirable for shipping purposes. Flesh is light red and is very sweet. Oz., 10c; $1 / 41 \mathrm{lb}$. 2.5c; 1b., 65c.

KLECKLEY'S SWEETS, OR MONTE CRISTO-WE regard this as the finest of all the medium early water melons for home use. The rind is too thin and tender to stand long-distance shipment. The fruits are uniform. Pkt., 5c; 0z., 10c; 1/4 lb., 30c; 1b., 75c.
ICE CREAM, OR PEERLESS-One of the best melons in cultivation. Rind thin, light, mottled green. Flesh bright scarlet; solid to the center; sweet as honey. Large pkt., 5c; 0z., 10c; 1/4 lb., 25c; lb., 65c.

FLORIDA FAVORITE-Oblong in shape, growing to a very large sizee; rind dark, with light green stripes; flesh light crimson, crisp and deliciously sweet. Pkt., 5c; oz., 10c; 1/4 1b., 25c; 1b., 6.5c.

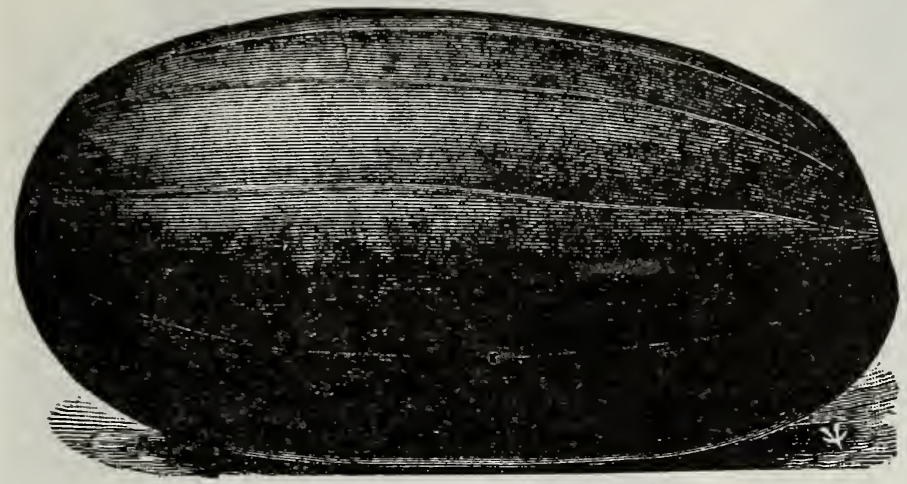

We consider the Kleckley's Sweet the best watermelon for this vicinity.

HALBERT HONEY-A new, exceedingly sweet and deliciously flavored melon, similar in size and shape to Kleckley's - Sweets, but of more regular form and much more productive. It is of handsome, long, oval shape, averaging about 18 inches in length and about 6 inches in diameter. The skin is an attractive, very dark green; the flesh is of a beautiful bright red, extending almost to the outer rind; is very tender and melting, and entirely free from stringiness. The rind, too, is so thin and brittle that it cracks open very easily and will not stand hauling or shipping long distances. For home use and nearby markets it is unequaled in quality; hardy, early, and productive. Pkt., 10c; 0z., 15c; 1/4 lb., 30c; lb., 80c.
CUBAN QUEEN-A very fine variety, growing to a great size; flesh bright red, solid and sweet. The skin is beautifully striped dark and light green. Melons are wonderfully solid, rind thin. They are enormously productive and ripen early. Pkt., 5c; 0z., 10c; $1 / 4$ lb., 20c; lb., 65c.

CITRON—For preserving; grows uniformly round and smooth; striped and marbled with light green; flesh white and solid. Pkt., 5c; 0z., 10c; 1/4 lb., 25c; 1b., 80c.

\section{Onion Seed}

CULTURE-Onions do best on a rich loam, previously cultivated for two years. Stiff clay and light sand are equally unfavorable. The land should be highly fertilized with well-rotted manure, complete fertilizers, etc. Fresh stable manure has a tendency to produce soft onions. Drill in four or five pounds of seed per acre, one-half inch deep. If sets are wanted, use 60 to 80 pounds per acre. Six to ten bushels of sets will plant an acre. Fine marketable size onions (according to variety planted) are easily produced the first year from early spring-sown seed. Culture should be frequent, though shallow. The same ground may be used for onions season after season, if well fertilified annually. Bone meal is an excellent fertilizer. Winter storage demands dryness and protection from sudden changes. Onions should never be handled while frozen.

\section{White Varieties}

WHITE GLOBE-A handsome, white, globe-shaped rariety: flesh fine, very white, rich and sweet: it is also one of the best keepers of the silver-skinned kinds. Pkt., 5c; oz., 35c; $1 / 4$ lb., 75c; lb., \$2.50.

WHITE PORTUGAI, OR AMERICAN SILVERSKINProduces early onion of mild flavor; largely used for growing sets and pickles. Large pkt., 5c; 0z., 25c; 1/4 lb., 65c; lb., \$2.00.

SIIVER KING-This is a grand onion. It is a mammoth grower, of beautiful pearly white color, almost transparent in appearance. To match Spanish King at fairs and exhibitions it is just what is needed. Pkt., 5c; oz., 20c; $1 / 4$ lb., 60c; lb., \$2.00.

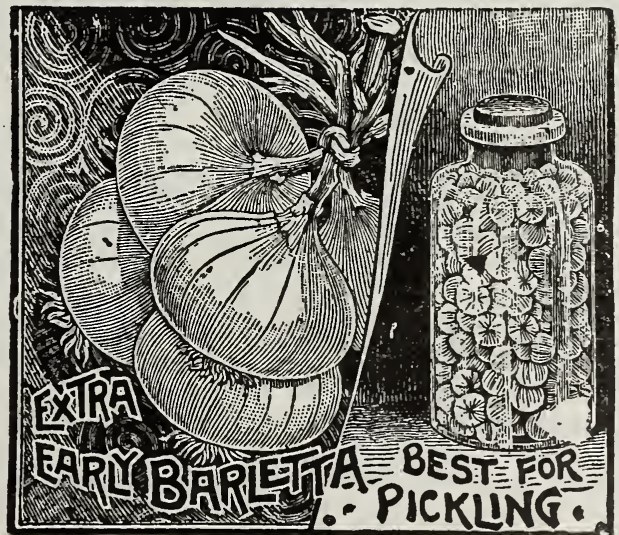

WHITE QUEEN, OR BARLETTA-Remarkable for its earliness and mild flavor; it is small and white-skinned; the leading variety for pickling purposes. Pkt., 5c; oz., $25 c$; $1 / 4$ lb., 65c; lb., $\$ 2.00$.

BERMUDA ONIONS-These onions grow to an immense size and are of beautiful form. The skin is very thin; flesh white, fine-grained, of mild and pleasant flavor. It will grow an onion from one to one and a half pounds from seed, but to attain full size, set out the bulbs the following spring. Pkt., 5c; oz., 35c; 1/4 lb., 75c; lb., \$2.25. 


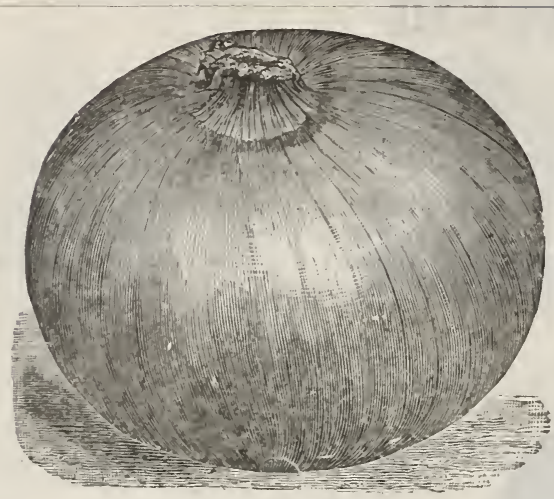

Yellow Varieties

YELLOW DANVERS-The leading large yellow kind, round, slightly flattened, flesh fine-grained, rather mild, very rich and sweet; one of the best keepers and shippers, and one of the most productive kinds. Pkt., 5c: oz., 15c; $1 / 4$ lb., 4.ic; lb., \$1.40.

YELLOW GLOBE DANVERS-This is the standard variety for winter use, producing well-ripened bulbs averaging two inches in diameter and nearly globe shaped. Skin a light golden brown or pale yellow; flesh pure whitee, crisp and mild in flavor. Pkt., 5c; oz., 15c; $1 / 4$ lb., 45c; 1b., \$1.40.

OREGON YELLOW DANVERS-It is a cross between the flat and the globe, on of the best keepers for our western climate. Pkt., 5c; oz., 20c; 1/4 lb., 45c; lb., \$1.40.

AUSTRAIIAN BROWN ONIONS-Are of medium size, though growing quite large under favorable conditions. Wonderfully hard and solid, the bulbs are most attractive for market, both as to form and appearance. Pkt., 5c; oz., 15c; 1/4 lb., 40c; lb., \$1.25.

MAMMOTH PRIZE-TAKER-Genuine seed of this variety produces the handsomest, largest Yellow Globe onion in the list. The yield per acre is larger than that or any other variety. Pkt., 5c; 0z., 20c; 1/4 lb., 50c; lb.; \$1.50.

\section{Red Varieties}

RED GLOBE-This beautiful strain of Red Globe onion surpasses all others in earliness, productiveness, perfection of shape, uniformity of size, richness of color and longkeeping qualities. Pkt., 5c; oz., 20c; 1/4 lb., 60c; lb., \$1.60.

EXTRA EARLY RED FLAT-Deep red in color; resembles the Red Wethersfield, except that it is much earlier and somewhat smaller; desirable for early market. Pkt., 5c; oz., 20c; $1 / 4$ lb., 50c; lb., \$1.50.

LARGE RED WETHERSFIELD-The standard red variety. Bulb large and somewhat flattened, oval-shaped; skin deep purple red; flesh purplish white, moderately fine grained and rather strong flavor. Very productive. Oz., 25c; $1 / 4$ lb., 60c; lb., \$1.60.

We handle both the Planet Junior and Iron Age Garden Tools. There are none better. See Pages 39 and 40.

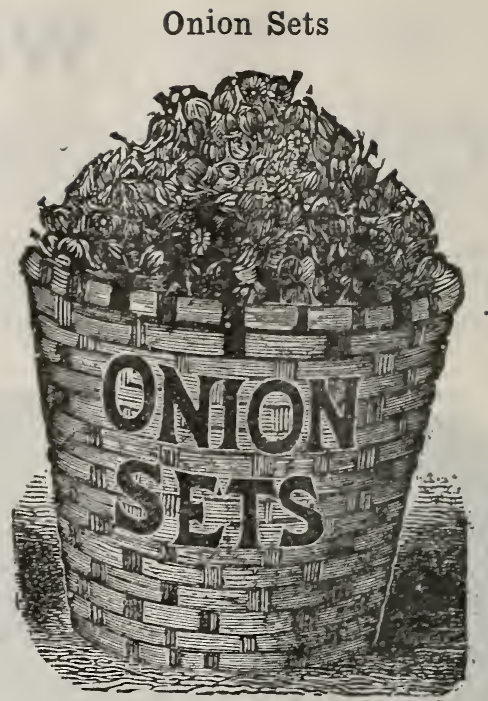

BOTTOM SETS-Are grown from seed that has been sown too thick to attain a large size. The small onions thus obtained are planted out, and are ready in a short time to pull as green onions for the table or bunched for the market. If left to stand they make ripe onions of the best quality, and come to maturity some six weeks earlier than a crop grown direct from the seeds.

YELLOW ONION SETS-These will produce handsome, well-ripened bulbs early in the season. By mail, 25c lb. For large quantities, write for prices.

\section{OKRA OR GUIMBO}

The pods, sliced, are esteemed for soups, stews, etc., and whether used green or dried, must be gathered when young.

WHITE VELVET. HENDERSON'S-Large, round, smooth pods; never ridged; prolific. Pkt., 5c; oz., 10c; $1 / 4$ lb., 20c.
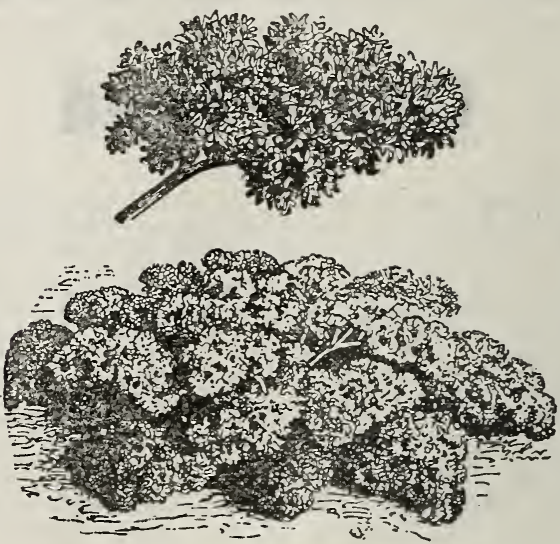

PARSLEY

Very useful for flavoring soups, meats and for garnishing. The green leaves are used for flavoring, or they may be dried crisp, rubbed to a powder and kept in bottles until needed.

CHAMPION. MOSS CURLED-A compact growing. finely cut and much curled variety of bright green color. Pkt., 5c; 0z., 10c; 1/4 lb., 20c; 1b., 65c.

\section{PEANUTS}

The peanut thrives and produces best on a lirht, sandy, fertile soil with a good clay subsoil. It possesses a long tan-root, which extends deep into the earth, drawing thence the nutriment which is beyond the reach of many of our cultivated crops. Per lb., 35c, postpaid. 


\section{Garden Peas}

Very scarce and high.

CULTURE-Sow early in the spring in rows, 13 to :4t inches apart. The peas will give quicker returns if covered only 1 inch deep, and where earliness is the most important, they may be treated in that way, but longer pods and more of them will be produced if the secd is planted in trenches 3 to 6 inches deep and covered with

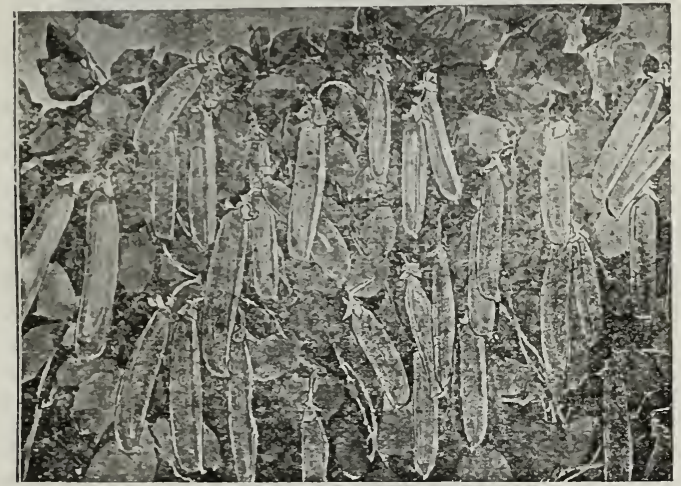

1 or 2 inches of soil. When the plants are 5 or 6 inches higl, fill the trench level with the surface. Sow every two weeks for succession. For field culture, they may be sown broadcast and plowed under. Two pounds for 100 feet of drill; 2 or 3 bushels in drills per acre.

\section{Extra Early Peas}

ALASKA, OR EARLIEST OF ALL-Earliest and best of all the blue smooth varieties. A smooth, blue pea, which in evenness of growth of vine and early maturity of pods is unequaled bv any other extra early pea. Vines two to two and one-half feet high, unbranched, bearing four to seven long pods, which are filled with mediumsized, bright green peas of excellent flavor. A grear favorite with our market gardeners for fall and early spring planting. Pkt., כc; lib., 25c postpaid, express or freight; lb., 15c; 10 ibs., \$1.25.

ICIEAN'S LITTLE GEM-A sweet, wrinkled pea, coming in a little later than the American Wonder; grows taller and continues in bearing longer. The quality of the pea is rery superior. Height, $\mathbf{1 5}$ inches. Pkt., 5c; 1b., 30 postpaid, express or freight; li., 20c; 10 lbs., \$1.50.

AMERICAN WCNDER-The earliest and best of the wrinkled sorts. A great favorite for family use. Has stout, branching vines, about nine inches high, and covered with well-filled pods, exceedingly sweet, tender and well flavored peas. Drv peas, medium size, much wrinkled and flattened, pale green. Pkt., 5c; lb., 30c postpaid, express or freight; lb., 20c; $10 \mathrm{lbs}$., $\$ 1.50$.

\section{Second Early Sorts}

NOTT'S EXCELSIOR-The best early dwarf pea. It combines to a wonderful degree the good qualities of the American Wonder and Preemium Gem peas. The vines are larger and more productive than American Wonder and earlier than Premium Gem. The peas, in sweenness unu quality, are unsurpassed. The most desirable sort tor tne market gardener and unexcelled for the home garden. ery hardy. It outyields them 20 to 30 per cent. The pods are one-third longer, and each pod contains from six to nine peas, which are usually fine flavored and tender. Pkt., 5c; lb., 30c postpaid, express or freight; 1b., $20 \mathrm{c}$; 10 iss., \$1.50.

MELTING SUGAR-The kind that has sweet, broad pods, and are used the same way as snap and string beans. This is the most popular of the edible podded varieties. The pods are large, straight, very tender and finely flavored. Vines medium height. Pkt., 5c; oz., 10c; lb., $35 \mathrm{c}$ postpaid.

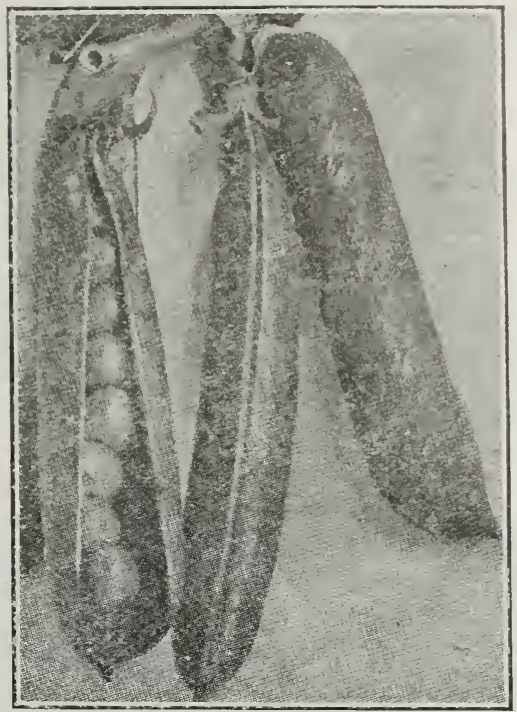

\section{Gradus}

GRADUS - This extra early wrinkled pea bears pods of large size, and combines quality with earliness. It is very hardy; can be planted fully as early as the smooth peas; grows vigorous and healthy; vines two and a half feet in height; very prolific. The quality and flavor are delicious, and the peas remain tender and sweet for a long time. Pkt., 5c; lb., 35c postpaid, express or freight; 1b., 20c; 10 ibs., $\$ 1.75$.

\section{Late Varieties}

DWARF TELEPHONE-Produces those handsome long pods. A great favoritee with our market gardeners. Immensely productive, of the finest quality and excellent sugary flavor: vines verv strong; the pods are of large size, filled with large, delicious peas. Height two feet. Pkt., 5c; lb., 30c postpaid, express or freight; lb., 20c; 10 lbs., $\$ 1.75$.

CHAMPION OF ENGLAND-Very rich and fine flavored; very productive; wrinkled. Height, four to five feet. Pkt., 5c; 1b., 30c postpaid, express or freight; 1b., 20c; 10 ibs., \$1.0̈0.

STRATAGEM-One of the best of the large, podded peas; the pods are of immense size, filled with large, dark green, wrinkled peas of the finest quality; vine of medium height, but very stocky, with broad, light green leaves, and bearing an abundance of large, handsome pods. Pkt., sc; 1b., 30c postpaid, express or freight; 1b., 20c; 10 lbs., $\$ 1.75$.

\section{Pumpkin}

CULTURE-Sow in good soil in May, when the ground has become warm, in hilis eight or ten feet apart each way, or in fields of corn about every fourth hill; plant at the same time with corn: always avoid planting near other vines, as they will hybridize.

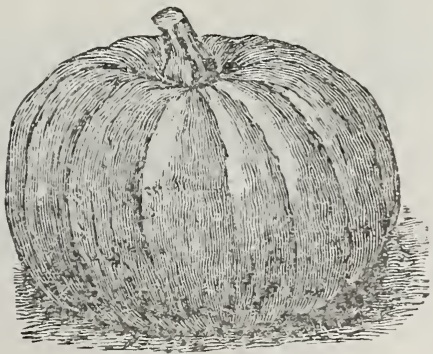

Early Sugar 


\section{PUMPKINS-Continued}

EARLY SUGAR-Fine-graincd, swcet and prolitic; smal in size, but one of the best for pies. Pkt., 5c; oz., 10c $1 / 4$ lb., 20c; 1b., $70 \mathrm{c}$.

IKENTUCKY FIELD, OR LARGE CHEESE-A popular variety in the South. Fruit flattened, the diameter being two or three times morc than the length. Skin mottled light green and yellow, changing to rich cream color as it matures: flesh tender and of excellent quality. Pkt., 5c; 0z., 10c; 1/4 1b., 20c; 1b., (60c.

BIG TOM-This is one of the largest, most uniform growing and productive varietics known; it has been produced by an anmual selection being madc for a number of vears from the old Golden Marrow by onc of the largest canning cstablishments in Ohio, and who annually grow hundreds of acres especially for camning; they say that they can find no variety equal to it for this purpose. Per 0z., 10c; 1/4 1b., 20c; 1b., 50c.

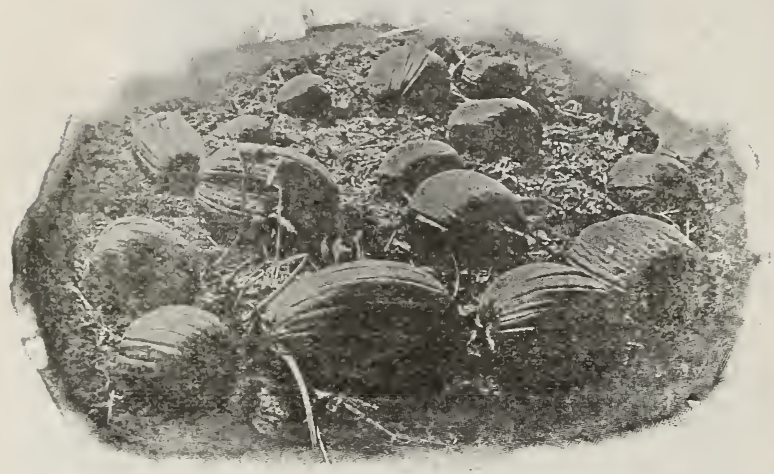

\section{Connecticut Field}

CONNECTICUT FIELD-A productive, large, orangecolored field pumpkin, usually grown for stock feeding, but it makes good pies. Pkt., 5c; 0z., 10c; 1/4 1b., 20c; lb., 50c.

MAMTMOTH PRIZE-The largest pumpkin grown; has attained a weiglit of 225 pounds. If you wish to see just how large a pumpkin can grow, try the Mammoth Prize. The quality is excellent. Pkt., 5c; oz., 15c; 1/4 1b., 30c; lb., $\$ 1.00$

\section{Parsnips}

CULTURE-Parsnips do the best in rich, deep soil, but will make good roots on any soil which is deep and mellow and moderately rich. As the
seed is sometimes slow to germinate it should be sown as early as possible. 5 - 3 Cover one-half inch deep and press Sive soil firmly over the seed. Give frequent cultivation and thin the
plants six or eight to the foot. One

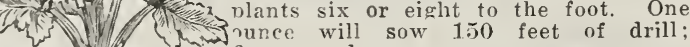

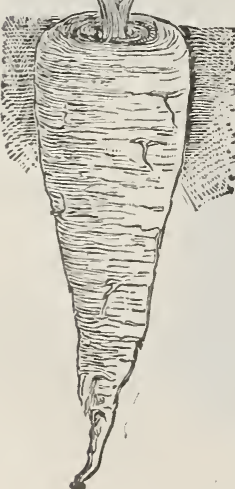

IMPRCVED GUERNSEY (Improved Half-Long) - A greatly improved and wonderfully fine strain of Guernsey narsnip. The roots do not grow so long as tho Hollow Crown, but are of greater diameter and more easily gathered. It is a very heavy cropper. - The roots are very smooth, the fesil is fine grained and of most exccllont ruality. Pkt., 5c; oz., 10c; $1 / 4$ lb., 3.) $;$ ib., \$1.00.

T.ПNTG SMOOTH, OR HOLLOW CROWN (Abbott's Improved Long Sugar, or Long White Dutch Parsnip) - A great cropper; tender, sugarv. and considered the best for geveral cultivation. Parsnins are improved iv remaining exnosed to the frost. 5c; oz., 10c; 1/4 lb., 3.5c; $1 \mathrm{~b}$. $\$ 1.00$.

\section{Peppers}

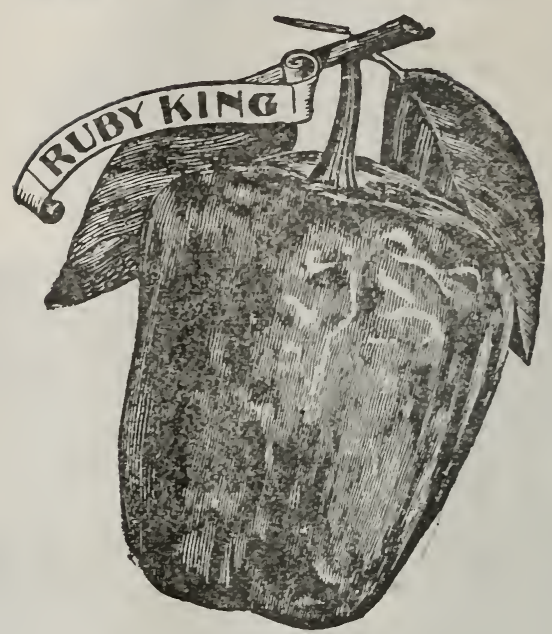

Pepper

Sow the seeds early in hotbeds or later, when the weather becomes warm, in open beds; when two or three inches high, transplant to a warm, mellow soil, in rows eighteen inches apart at one foot apart in the row. Guano and hen manure are excellent fertilizers, and will greatly increase the yield.

RUBY KING-An improved American sort, reaching the largest size, yet retaining the symmetrical shape of the smaller sorts. It is very bright colored, beautıful, sweet and mild flavored. Pkt., 5c; oz., 30c; 1/4 lb., 75c.

LARGE BELL, OR BULL NOSE-A large, mild, thickfleshed variety. One of the best for stuffed pickles. Pkt., 5c; oz., 30c; 1/4 lb., 75c.

LONG RED CAYENNE-Brilliant coral-red pods, three or four inches long, and a prolific bearer; very pungent and used very largely with pickles when green. Pkt., 5c; oz., 25c; $1 / 4$ lb., 75c.

RED CHIII-Small, bright red peppers, very hot and pungent, and generally used for making "'pepper sauce'; very prolific. Pkt., 5c; oz., 25c; $1 / 4$ lb., 75c.

\section{RHUBARB OR PIEPLANT}

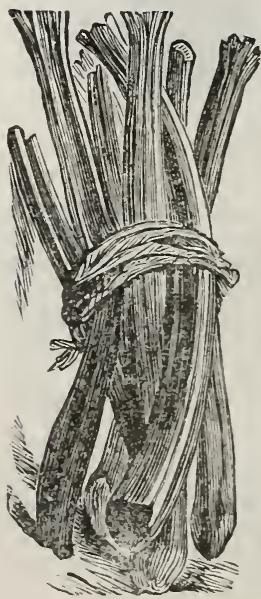

CLUTURE - Rhubarb succecas best in deep, rich, somewhat retentive soil. The richer its conaition and the deeper it is stmrea, the better. Sow in drills an unch dcep, and thin out the plauts to six inches apart. In the fall transplant the young plants into very highly manured and deeply sirred soil, setting them four to six feet apart each way, and give a dressing of coarse manure each spring. The stalks should not be plucked until the second year, and the plant never allowed to exhaust itself by running to seed.

VICTORIA, OR MAMMOTHVery large: finest cooking variety. Pkt., 5c; oz., 15c; $1 / 4$ lb., 45c; lb., \$1.40. 


\section{Radishes}

CULTURE-Radishes must make a rapid growth to be crisp and tender. For early use seed should be sown in the hotbed, in drills four or five inches apart and half an inch deep. For an early crop in the open ground select a sandy soil and a warm south border under the shelter a sence or building, if possible. A load of fresli, sandy loam from the woods is better for the radish crop. As soon as the first leaves appear sprinkle with soet or ashes to save from the little furnip fly. One ounce will sow 150 feet of row.

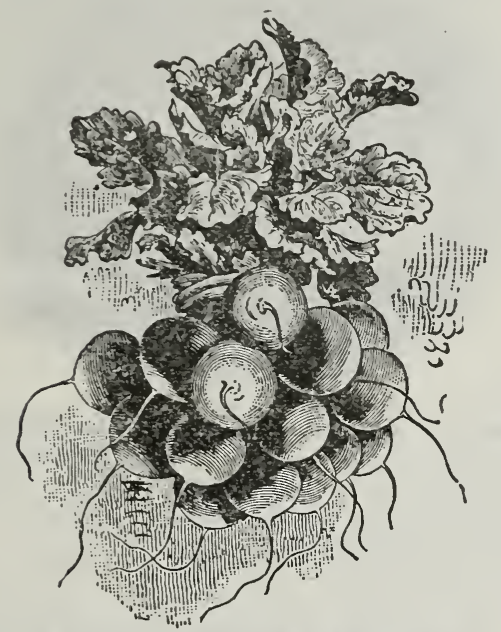

BCARLET TURNIP WHITE-TIPPED RADISH,

THE SECRET IN GROWING GOOD RADISHES consists chiefly in the observance on the part of the grower of three points. First, they should be grown on quick, light soil. Second they should be given plenty of water; and last, but not by any means least, the right kind of seed should be sown. Radishes grow very quickly, and if not supplied with plenty of water are apt to be pithy.

\section{Early Round Varieties}

EARLY SCARLET TURNIP, WHITE TIPPED-American grown. The favorite variety for ontdoor cultivation; medium size, uniform shape. color bright scarlet, sharply contrasted with white tip, which makes it most attractive. It grows quickly; flesh white, crisp and of the best quality. Pkt., 5c; oz., 10c; 2 oz., 15c; 1/4 lb., 20c; lb., 60c.

EARIY SCARIET TURNIP, WHITE TIP-French grown. This is similar to the American grown, but owing to the selection of only the best roots for seed stock, this seed produces more perfect bulbs. Pkt., 10c; oz., 15c; $1 / 4$ lb., 30c; lb., 75c.

EARLY ROUND DEEP SCARLET-Similar in form to the Scarlet 'Turnip-Rooted, but much darker in color; flesh white, very crisp and tender; top small, well adapted for growing in frames. Pkt., 5c; oz., 10c; 2 oz., 15c; 1/4 lb., 20c; lb., 60c.

EARLY CRIMSON GIANT-The largest early Scarlet Turnip-Shaped Radish. A new early radish, double the size of any of the other early turnip-shaped type, but notwithstanding its immense size does not get hollow and pithy. The flesh is a sparkling white, solid, crisp and juicy, and of the mildest flaror. The shape of the bulbs vary from round to almost oval, but the bright, deep crimson color of the skin remains quite constant. Excellent for both forcing and open ground. Pkt., 5c; oz., 10c; $1 / 4$ lb., 25c; 1b., 75c.

\section{OLIVE SHAPED}

FRENCH BREAKFAST, OR HALF-IONG WHITE TIPPED-Medium size, of quick growth, crisp and tender; terminates more abruptly than the Half-Long Scarlet, lower end and tap root white. Pkt., 5c; 0z., 10c; 2 oz. 15c; $1 / 4$ lb., 20c; 1b., 60c.
EARLY LONG SCARIET-The leading variety either for the family or market garden. From six to eiglit inches long, standing nearly half above the ground; bright scarlet, smooth, crisp, tender and mild. Pkt., 5c; oz., 10c; 2 oz., $15 \mathrm{c}$; $1 / 4 \mathrm{lb}$., 20c; 1b., \$60c.

IMPROVED CHARTIER-Roots long, tapering ratner abruptly and attaining a very large size. Of rapid growth, it is soon ready for the table, remaining crisp and tenoer until fully grown. Color, scarlet above, shading into white at the ip. Flesh white and mild flavored. Pkt., 5c; oz., 10c; 2 oz., 15c; $1 / 4$ lb., 20c; lb., 60c.

NEW WHITE ICI CLE - Entirely dis tinct, long, slender, pure white. $\mathrm{v}$ e $\mathrm{r}$ early; much the earliest and finest long white. It is ready for use fully as early as Loun Scarlet; short top, with less foliage, rendering it more desirable for forcing. In the open ground the roots continue brittle crisp and mild, until they are fully as large as those of the Long Brighton Scarlet. It is ready for use follow ing th e olive-shaped Earliest White, and destined to become a. leading variety. In recent years strains of White Wood's Frame and Chartiers have been introduced and found of poor quality. but the Icicle is, perhaps, superior to the finest red ones. Roots pure, snowy white. four inches in lenoth and half an inch in diameter: they retain their crispness and fresh, mild flavor until fully six inches long and an inch in diameter. Pkt., 5c; oz., 10c; 1/4 lb., 25c; 1b., 60c.

LONG WHITE VIENNA, OR LADY FINGER-The best long white radish grown; pure white, long, tender and sweet; a favorite also for its beauty of form and rapid growth. Pkt., 5c; 0z., 10c; 2 oz., 15c; 1/4 lb., 20c; lb., $60 \mathrm{c}$.

\section{Winter Varieties}

IONG BLACK SPANISH-Very hardy and good for winter use. If stored in sand will keep good all winter. The roots, which present a rusty, black appearance, are large, firm and not liable to become pithy. Pkt., 5c; oz., 10c; $1 / 4$ lb. 20c: lb., 65 c.

MAMMOTH CALIFORNIA, OR WHITE CHINA-Extensively grown by the Chinese, who introduced it into California. Very large and cylindrical, terminating abruptly with little tap root; mild and tender, and keeps well all winter. The skin and flesh are of a transparent white. Pkt., 5c; oz., 10c; 2 oz., 15c; 1/4 b., 25c; 1b., 65c.

CHINA ROSE-One of the best fall and winter varieties. Half-long shape; upper part bright crimson, shading to white. Flesh white, firm, tender and of superior quality. Pkt., 5c; 0z., 10c; 1/4 1b., 20c; 1b., 65c.

\section{SPINACH}

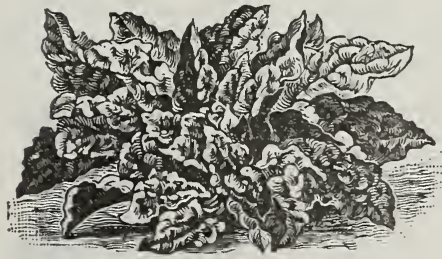

CULTURE-It is ne of the most easily managed of all vegetables, requiring but little culture. The main crop is sown in September, and it is sometimes covered with straw during winter, which prevents it from being cut with frost. For summer use it may be sown at intervals of two or three weeks from March to August. Spinach is best developed, most tender and succulent when grown in rich soil. One ounce to 100 feet of drill; 10 to 12 pounds to an acre. 
flavored; very productive. Pkt., 5c; 0z., 10c; 1/4 1b., 25c; lb., $75 \mathrm{c}$.

MAMMOTH WHITE BUSH SCALLOP-The best sum.

BLOOMSDALE-A very erly variety. Is hardy and may be planted for early spring use. Pkt., Jc; oz., 10c; $1 / 4$ lb., 20c; lb., 40c.

LONG STANDING-An improved variety, slow going to seed, and perhaps the hest for general use. Pkt., 5c; oz., 10c; 1/4 1b., 20c; lb., 40c.

IMPROVED THICK LEAVED-A variety which grows very rapidly, forming a cluster of large, very thick, slightly savoyed leaves of fine color and quality when cooked. Best for market gardeners. Pkt., 5c; oz., 10c; $1 / 4$ lb., 20c; lb., 40c.

\section{SALSIFY OR VEGETABLE OYSTER}

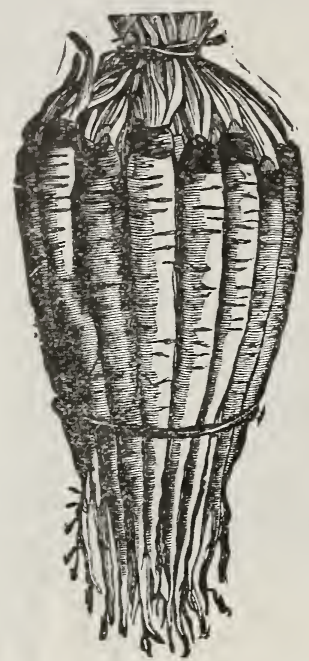

mer sort for the market: very productive and of good size. Pkt., 5c; 0z., 10c; 1/4 1b., 25c; 1b., 75c.

ENGLISH VEGETARLE MARROW-A favorite English variety, bearing freely oblong, dull yellow fruits 10 to 15 inches in length by 4 to 5 inches in diameter; flesh before ripe, tender, marrowy and delicious. Oz., 10c; $1 / 4$ lb., 25c; 1b., 85c.

\section{Autumn and Winter Varieties}

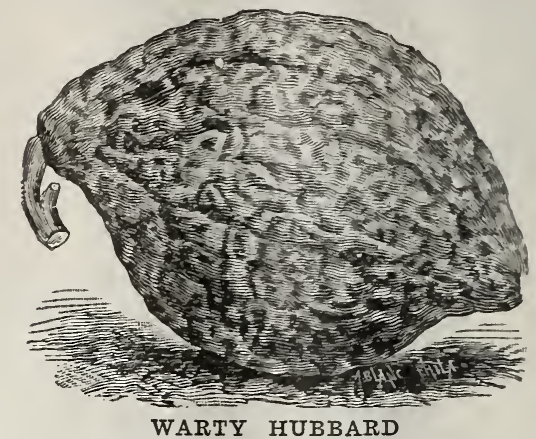

GOLDEN HUBBARD-This is a very distinct sort of the shape and general character of the Hubbard, but little smaller; earlier to mature, and of a rich, orange-red color, instead of the dark olive-green of the old Hubbard, while the flesh is a little deeper colored and fully as good quality. Pkt., 5c; 0z., 15c; 1/4 lb., 35c; 10., \$1.00.

CHICAGO WARTED HUBBARD-Is similar in size and quality to the Hubbard. The vines are vigorous and productive, while the large, dark olive-green fruits are rather more heavily warted. Very handsome in appearance; an excellent keeper and of splendid quality. Pkt., 5c; oz., 15c; 1/4 lb., 35c; 1b., \$1.00.

NEW DELICIOUS-This new fall and winter squash resembles the old Hubbard; average weight is between five and ten pounds. Seed cavity small: flesh exceedingly thick, compact, fine grained; color, golden orange. The flesh is meaty, granulated, tender and almost of mealy dryness, cooking sweet and rich, whether steamed, baked, boiled or made into pies. Pkt., 10c; 0z., 15c; 1/4 1b., 40c; $1 \mathrm{lb} ., \$ 1.25$.

BOSTON MARROW-A good keeper, of excellent flavor; flesh orange colored and fine grained. Pkt., 5c; oz., 10c $1 / 4$ lb., 35c; lb., $\$ 1.00$.

MAMIMOTH CHILI-The largest variety grown, having attained a weight of over $200 \mathrm{lbs}$; round, flattened at the ends; rind deep orange; flesh deep yellow, thick and very nutritious; sometimes used for the table, but more desirable for stock feeding. Pkt., 5c; 0z., 15c; 1/4 1b., 35c lb., S5c.

\section{Tomatoes}

\section{Summer Varieties}

CULTURE-The plants are very tender and sensitive to cold and planting must be delayed until settled warm weather. The general principles of culture are the same as those given for cucumbers and melons. but squash is less particular as to soil. The summer varieties should be planted four to six feet apart each way, and the winter sorts eicht to ten. Three plants are sufficient to a hill. In gathering the winter sorts care should be taken not to bruise or break the stem from the squash, as the slightest injury will increase the liability to decay.

MAMMOTH SUMMER CRONK NECK-An early, prolific kind. having a solid curved neck; rn skin is yellow, thin, liard and very warty; flesh tender and 0 good quality. Twice as large as the ordinary Crookneck and ser eral davs earlier. Pkt., Jc; $0 z$. 10c; $1 / 4$ 1b., 25c; 1b., 7.5c.

EARLY YELIOW IMAIMMOTBUSH SCALLOP- In early, flat. scallop-shaped variety: color yel.
low; flesh pale yellow and well

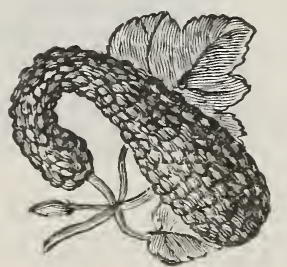

Summer Crookneck
CULTURE-Sow the seed in March and April in the hotbed or in spots in a sunny exposure in the house. If it is desired to make very healthy stock plants, they may be transplanted or repotted when about two or three inches high. When five or six inches high. if the ground has become warm, transplant to the open ground, on a rainy or cloudy day, if possible: if not, the young plants should be liberally watered and shaded from the hot sun. If it is desirable to have the fruit ripen as early as possible, in preference to a heavy crop, select rather noht, poor soil, and a sunny location. Trimming off the laterals, training to a stake, and propagating by slins are believed by many to promote earliness. Set the plants four feet apart each way, upon mounds of earth, to allow the foliage to open and let the sun in amongst the fruit. A cheap trellis, made by driving three stakes around the plants and encircling them with three or four barrel hoops, makes a very nice support for training them on

SPARK'S EARLIANA-The earliest large and smooth tomato. The most perfect of all tomatoes. Of large, uniform size and beautiful red color. Quality almost beyond praise. A most vigorous grower and heavy bearer, continuing until frost. Succeeds everywhere and especially recommended for this section. The above claims may seem strong, but they have been abundantly proved by thousands of planters who have grown this grand tomato since 
its introduction three years ago. Spark's Earliana is as near seedless as any tomato, giving but 12 to 15 pounds of seed to the acre, while other varieties yield from 75 to 100 pounds to the acre. For this reason the genuine seed can never be sold at a low price. Pkt., 5c; oz., 30c; $1 / 4$ lb., SOc; lb., \$2.50.

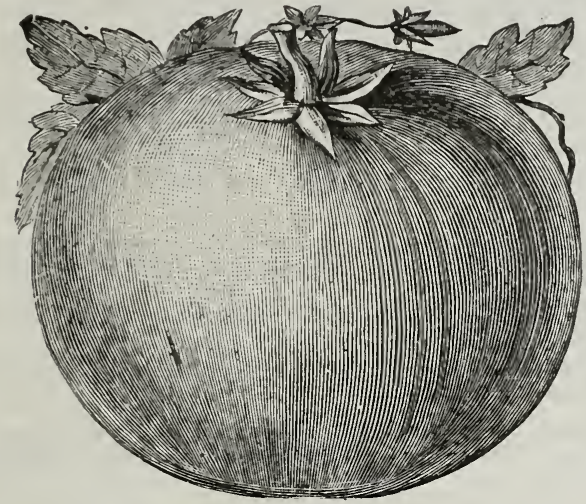

LIINGSTON'S CORELESS-A new bright red tomato of the globe-shaped type, almost round, being about the same diameter each way, making it a most profitable variety for canning. It is a strong grower and a heavy cropper, a grand slicing variety and ripens all over and through. Entirely free from hard green core. Pkt., 10c; oz., 50c.

DWARF CHAMPION, OR TREE TOMATO-The plant is dwarf and compact; fruit medium size, rich, glossy red, smooth and solid; fine for private gardens. Pkt., 5c; oz., 25c; $1 / 4$ lb., 75c; lb., \$2.50.

ESSEX EARLY HYBRID-Very similar to the Acme; fruit dark purple; always smooth and handsome; in quality it is classed with the best; will give satisfaction wherever the Acme does. Pkt., 5c; 0z., 25c; 1/4 lb., 75c.

NEW TOMATO-CHALK'S EARLY JEWEL-The large, handsome fruits are very solid and deep through, being almost round or ball shaped; will measure nearly three and a half inches across by nearly three inches in depth, from stem to blossom end. Color, brightest scarlet, ripening right up to the stem without any cracks or green core. The foliage is rather sparse and open, admitting the sunlight to the center of each plant, so that all the fruits are thoroughly ripened, but the leaves are dark green and not inclined to curl, as in most other first early varieties. Pkt., 5c; 0z., 35c; $1 / 4$ lb., $\$ 1.00$.

ATLANTIC PRIZE (Extra Early)-A distinctly early variety, of good size and smooth surface. Many of the objections to the usual early kinds, such as undersize, deep corrugations and rough skin, are overcome in the Atlantic Prize. Pkt., sc; 0z., 25c; 1/4 lb., 70c.

NEW STONE-Fine for main crop; very large; colos bright scarlet; very smooth, ripening up to the stem without a crack; exceedingly solid and firm fleshed; an excellent shipper; quality the very best; not subject to rot. Superior for canning. Pkt., 5̈c; 0z., 25c; 1/4 1b., 75c.

PEACH-This is a distinct and very attractive tomato for preserving, eating from the hand or table. Fruit resembles a peach in shape, size and color, and is covered with a delicate bloom, which makes the resemblance more striking; flesh tender and of good flavor. Pkt., 5c; oz., zasc.

GROUND CHERRY, OR HUSK-Plants of low, spreading growth and immensely productive. The small yellow fruits are each enclosed in a husk or covering. When ripe the fruits are an inch in diameter, bright yellow and of very sweet flavor; highly esteemed for preserving or making pies. Pkt., sc; oz., 25̃c.

YELLOW PEAR-SHAPED-A small-fruited variety, which is golden-yellow. It is very useful for salads when the fruit is simply cut in two lengthwise. Pkt., 5c; 0z., 25c.

\section{Turnips}

For feeding stock in fall and winter there is nothing superior to turnips and rutabagas, as they are much liked by all kinds of stock and serve to keep them in good condition. We cannot too earnestly recommend farmers to increase their sowings largey, for we are sure the crop will prove remunerative.

CULTURE-For early, sow as soon as the ground can be worked, in drills 15 to 18 inclise apart, and half an inch deep. Thin to six inches. in the row. Turnips will grow on any soil that is moderate rich. An essential point is to make them grow quickly, otherwise they are apt to be tough and woody. They do best in light, loamy soil, that which has been manured for a previous crop is preferable to manuring with stable manure at time of sowing, as in this case they are liable to be worm eaten, hence unsalable. Two pounds will plant an acre.

EARLY PURPLE TOP, STRAPPED LEAVED-One of the best and most universaly grown; small, erect top, round, flat; purplish red above; white underneath; flesh firm, but very tender and sweet; it is soon ready for the table and keeps well. Pkt., 5c; 0z., 10c; 1/4 lb., 20c; lb., 60c.

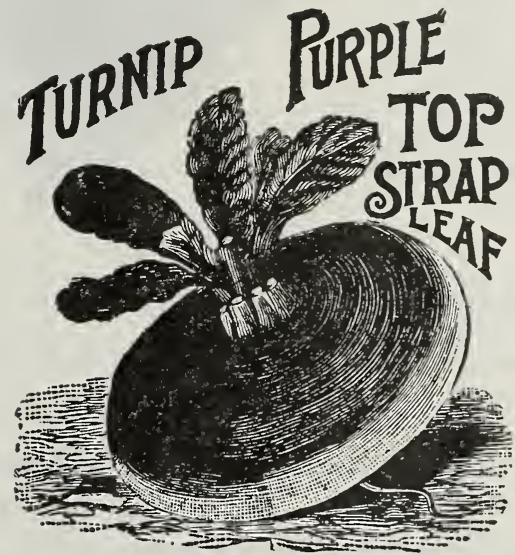

EARLY FLAT WHITE DUTCH, STRAPPED LEAVED -A leading white-fleshed-variety, and one of the best, either for family, market garden or field crop; it is of medium size and produces a large crop. The flesh is firm but tender, and of a superior rich, buttery flavor. A good keeper. Pkt., 5c; 0z., 10c; 1/4 lb., 20c; lb., 60c.

WHITE EGG-A quick growing egg-shaped, perfectly smooth, pure white variety, with small top and rough leaves. It grows half out of the ground; the flesh is very sweet, firm and mild, never having the rank, strong taste of some of the early varieties. Pkt., sc; oz, 10c; 2 oz., 15c; 1/4 lb., 25c; 1b., 65c.

EARIY SNOWBALI-A perfectly globe shaped, white skinned turnip. It is exceedingly productive. The flesh is fine grained, firm and of very delicate flavor. It is one of the best keeping of the white fleshed sorts. Very early and particularly adapted for family and market use. We recommend it to market gardeners because its earliness and fine appearance make it a very profitable variety of turnip. Pkt., 5c; 0z., 10c; 1/4 lb., 25c; lb., 65c.

POMERANIAN WHITE GIOBE, STRAPPED LEAVED -This is a free growing, rough leaved sort, useful for both table and stock. It is not quite so rapid in growth as the flat varieties, may be expected to come in as a succession, in autumn and is admirable for table use in early winter. Plkt., 5c; oz., 10c; 1/4 1b., 20c; 1b., 60c.

YELLOW ABERDEEN-Round, medium size, light yellow; stained with purple on top; produces a large crop; is hardy and keeps well; flesh very firm but tender and sweet. Pkt., כc; 0z., 10c; 2 oz., 15c; $1 / 4$ lb., 20c; lb., 60c.

PURPLE-TOP WHITE GLOBE-A variety of the Purple-Top Flat Turnip, from which it originated. It is globular in form, of beautiful appearance and of most excellent quality. Equally desirable for table or stock. It keeps well and is a fine market sort. Pikt., 5c; oz., 10c; 1/4 lb., 20c; 1b., 60c. 


\section{TURNIPS-Continued}

COWHORN-Sometimes called Long White. Is slightly crooked, pure white, except a little shade of green at the top. Grows half out of the ground and is of very rapid growth; is delicate and well flavored. Has proved itself one of the best stock turnips ever introduced in the West, and is an immense yielder. Pkt., 5c; oz., 10c; $1 / 4 \mathrm{lb}$., 20c; Ib., 60c.

\section{Ruta Bagas or Swedes}

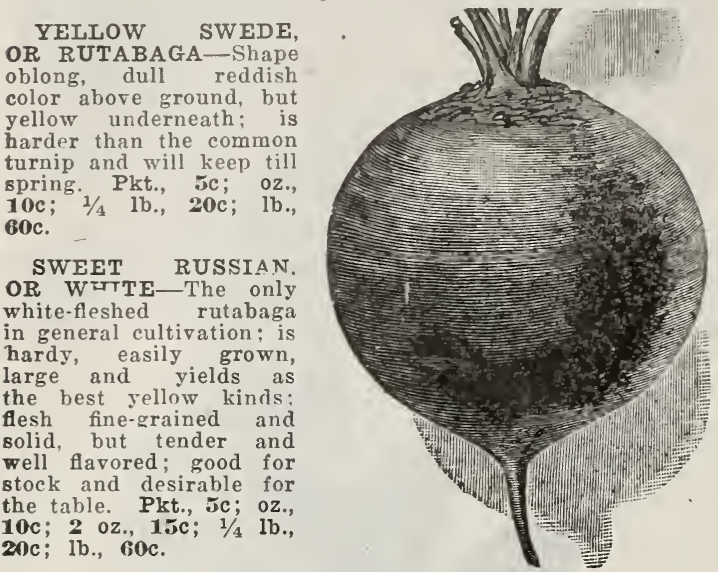

TOBACCO

CONNECTICUT SEED LEAF-A largely cultivated sort in America. Large pkt., 5c.

HAVANA-A genuine Cuban strain. Pkt., 5c.

\section{HERBS}

ANISE-Used for cordials, garnishing and flavoring. Pkt., 5c; oz., 10c.
BALM-Leaves used for making pleasant beverages. Pkt., 5c; 0z., 25c.

BASIL-Sweet; the leaves are used in flavoring soups, etc. Pkt., 5c; oz., 15c.

CARAWAY-Grown for seeds; used for flavoring. Pkt., Jc; oz., 15c.

CATNIP, OR CATMINT-Leaves and young shoots for seasoning. Pkt., 5c; 0z., 35c.

DILI-Seeds liave an aromatic odor and pungent taste. Pkt., 5c; oz., 10c; $1 / 4 \mathrm{lb}$., 25c.

FENNEI-Sweet; ornamental; when boiled, used in fish sauce. Pkt., Jc.

CORIANDER - Seeds used in the manufacture of liquors, in confectionery and culinary preparations. Pkt., 5c; oz., $10 \mathrm{c} ; 1 / 4 \mathrm{lb}$., $25 \mathrm{c}$

HOREHOUND-For seasoning and cough remedy. 'Pkt., 5c; oz., 20c.

IAVENDER -An aromatic, medicinal herb. Pkt., 5c; oz., 20c.

MARJORAM-Sweet; leaves and shoots for seasoning. Pkt., 5c; oz., 15c.

SUMMER SAVORY-Used for flavoring soups. Pkt., 5c; 0z., 10c.

THYME-Leaves and young shoots used for seasoning: a tea is made from leaves, a remedy for headache. Pkt., sc; oz., 30c.

\section{TREE SEEDS}

Single Pound Prices are by Mail, Postpaid.

PEACH PITS-For nursery stock. Lb., 20c; 100 lbs., \$3.50.

APPLE SEED-Oz., 10c; $1 / 4 \mathrm{lb} ., 40 \mathrm{c} ; \mathrm{lb} ., \$ 1.10$.

CHERRY PITS (Mahaleb)-Oz., 10c; 1/4 lb., 25c; lb., $85 \mathrm{c}$.

PEAR SEED (Pyrus Communis) - The best imported for nursery stocks. Oz., 15c; $1 / 4$ lb., 45c; lb., \$1.50.

QUINCE SEED-Oz., 20c; $1 / 4 \mathrm{lb}$., 50c; lb., $\$ 2.00$.

LOCUST, HONEY-Oz., 10c; $1 / 4$ lb., 20c; lb., 60c.

The Inland Seed Co.'s Seeds grow We test them all, and if we do not find sufficient vitality, they are destroyed.

The new Postal Law now in effect, allows us to send up to eleven pounds of seed at the rate of two ounces for one cent. It also enables us to send many articles we list as per prices given on the first leaf of this catalog. You will be obliged to figure out your postage as per the zones given. Any postage to your credit will be returned at once. 


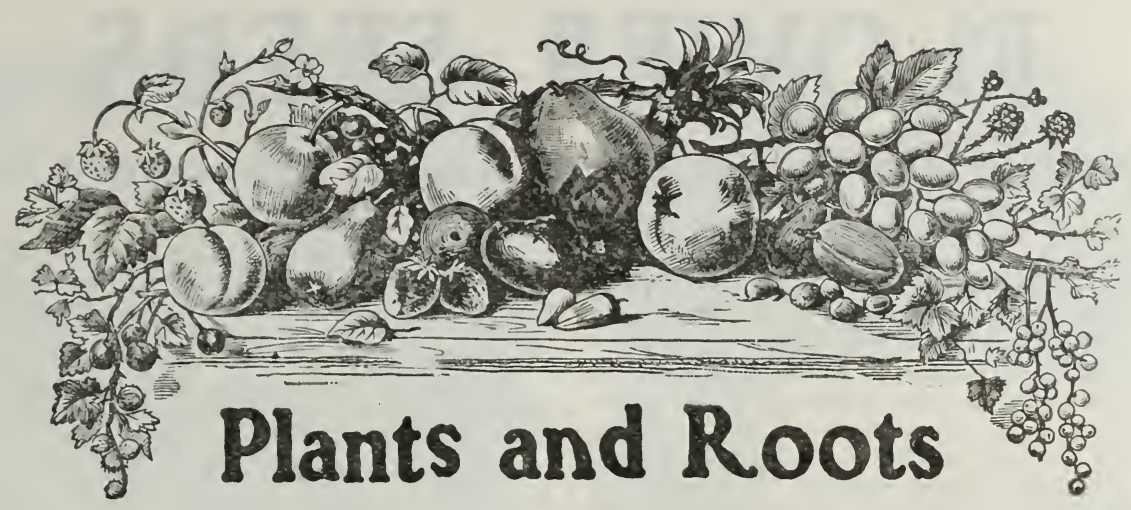

\section{VEGETABLE PLANTS AND ROOTS}

We grow large quantities of regetable plants, and can supply all of the varieties listed below, in their proper season, in most any quantity. "We have made arrangements this year so we can supply all vegetable plants in two grades -plants direct from the seed beds and those that have been transplanted into shallow boxes.

TRANSPLANTED PLANTS are much stronger and better rooted and are well worth the price, especially in the early part of the season. We can supply most of the lead. ing sorts.

\section{ASPARAGUS ROOTS-}

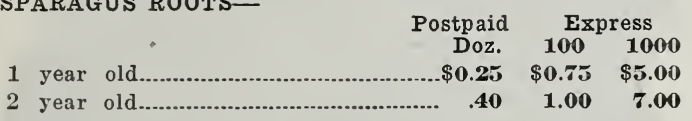

\section{CABBAGE PLANTS-}

E a r ly Jersey Wakefield, transplanted ...............................................

Early Jersey Wakefield, not trans.

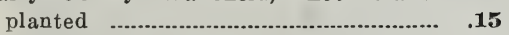

Danish Ballhead ................................... ...15 Cauliflower, Snowball

Express

CELERY-

Early White Plume, transplanted......\$.25

Early White Plume, Seeding.............. .20

Golden Self-Blanching, transplanted .25

Golden Self-Blanching Seedling...... .20

Late varieties, Seedlings..................... $\mathbf{. 1 5}$

PEPPERS-

Ruby King or Bull Nose...................... .25 $\quad .75 \quad \mathbf{5 0 0}$

TOMATOES-

Earliana, transplanted

Dwarf Champion, transplanted

Dwarf Champion, not transplanted..

EGG PLANT

TOBACCO

CHIVES

Bunch

PARSLEY

SAGE

HOP ROOTS

MINT ROOTS

HORSE HADISH SETS.

\section{RHUBARB ROOTS}

It is too expensive to send only the very smallest roots by mail, so we list same ony by express or freight:

1 year od

Each. Doz.

2 year old.

$\$ 0.10$ \$0.75

$.15 \quad 1.00$
100

$\$ 3.50$

\section{STRAWBERRY PLANTS}

HOOD RIVER-The leading standard shipping variety. The berry that has made the town of its name famous, and its growers financially rich. Dark red color, uniform size, good quality, but not heavy in yield. A specialty berry for the grower whose market is somewhat distant.

GLEN MARY-A bright, handsome, prolific, standard sort, grown the country over and perfectly reliable. Some large growers claim for this the par excellence in straw. berries.

SENATOR DUNLAP-Its color is a rich dark red, with glossy finish. It has become a very popular variety, perhaps on account of its uniformity.

WARFIELD-The most popular pistillate variety grown. It is a large, beautiful, cone-shaped berry with a fadeless, dark red exterior; the deep red color is extended clear to the center of the fruit. Exceptionally fine for canning and attractive in the box. Any variety that we offer will fertilize it except Gandy, Aroma and Marie.

MAGOON-Of first quality, great productiveness, at tractive shape and color; good for canning.

WM. BELT-Nothing better for quality, shape and at tractiveness. A reliable and trustworthy variety; ripens evenly; prolific and will meet the expectations of the most fastidious.

GANDY-A variety that has not yet today found its equal as a truly reliable and all-round late producing berry. For 20 years since its introduction it has remained at the head of the list in its seasons, although many varieties have been introduced claiming superiority, and while some of them may equal, the majority are found to be wanting. The plant is a rampant grower, having strong fruit stems, holding the heavy weight of the fruit erect; slow in forming and thereby ripening its fruit and in the height of its glory when the early and midseason varieties are about done fruiting.

AROMA-A late variety and among the best of the late ripening varieties. In comparison with the Gandy, it will be found that it commences to ripen a little earlier similar to it in size and productiveness. It is planted extensively both North and South. Quality the best of any, comes nearer being the true strawberry flavor than all others. It is the best for eating from the vines, with cream, shortcake, preserved or canned. Its shipping qualities are of the best.

\section{PRICES}

Postpaid, Doz. $\quad \begin{array}{cc}\text { Express } \\ \mathbf{1 0 0} \mathbf{1 0 0 0}\end{array}$

MAGOON (S), medium early.............. \$0.30 $\$ \mathbf{\$ 0 . 8 5} \quad \$ 5.00$

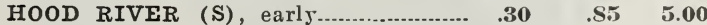
GLEN MARY (S), medium early ..........

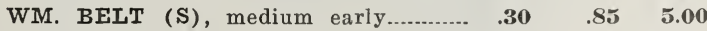

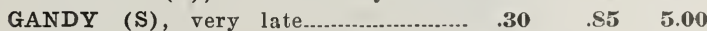
AROMA (S), late................................... WARFIELD (P), medium early ............ $\begin{array}{lllll}\text { SENATOR DUNLAP (S), med, early.. } & .30 & .85 & \mathbf{5 . 0 0}\end{array}$

We also handle Pansy, Aster and other Flower Plants.

For Cultural Directions of Hot Beds and Frames, see Page 74. 


\section{FLOWER SEEDS}

\section{Practical Directions for Culture, Treatment, Etc.}

ANNUALS (A) - Sow in April or May, according to the latitude, in shallow boxes or pots placed in a warm window, a hotbed, or, if possible, in a greenhouse. A second sowing onght to be made from two to four weeks after for a succession, as well as to provide against failure the first time. $\mathrm{l}^{\prime} \mathrm{or}$ sowing seeds in there is nothing better than shallow boxes from 2 to $;$ inches deep, and of any convenient size. The most suitable soil for all the smaller kinds is a very fine, rich, sandy loam. That from ond hotbeds is excellent, or sods from an old pasture piled up and allowed to rot for two or three years and then mixed with a little old stable manure and sand. After the seeds are up, care must be taken to give them plenty of air and moisture, yet not too much water, or iney will "damp off." When the young plants are well out of the sced-leaf, they must be transplanted to new boxes. If pots 2 inches or more in diameter can be had, set out from three to a dozen or more of the young seedlings along the edges of the pot, so that as soon as the ground is warm enough they may be easily turned out and planted singly, as by that time they will have made good roots. When pots cannot be had, boxes, tin cans, etc., may be substituted.

A common mistake in sowing flower, as well as other seeds, is covering too deeply. As a general rule, cover only to the depth of the thickness of the seeds; or, with medium-sized seeds, like Balsams, Zinnias, etc., half an inch or so is none too much. Such fine seeds as Portulacas neeci only be pressed into the soil with a piece of board or the paln of the hand. Always press the earth down firmly after sowing all flower seeds, else there is danger of their drying up before the roots can get firm hold of the sort. Seeds of the hardier Annuals may be sown where they are to grow; but, as a rule, it is preferable to transplant, as the plants are generally stronger and stand the drought better. During very dry weather, and when the seedlings are first set out, they should be watered frequently. Provide some support for all such Annuals as require it.

The weeds should be kept down and the ground loosened often, so that the plants will receive the full benefit of the rains and dews, which they will not if the ground is allowed to become hard and baked.

Seeds of Biennials and some Hardy Annuals may be sown in July and August in the open and in September in boxes and placed in coldframes. They will make strong plants by spring and flower early. Do not put on the sashes until heavy rains and frosts begin, and then always remove during the day whenever the temperature is above freezing in winter.

BIENNIALS (B) and PERENNIALS (P)-These require the same treatment as the Annuals. In addition to the above, both Hardy Biemnials and Perennials may be sown in the open border from July to September; for, if not sown until spring, the seeds of many Perennials require several months, and some even as long as two years before they germinate. In this case, it is a good plan, at the ecmmencement of frost, to cover them liohtly witl straw, leaves or any dry litter, in order to afford some protection from the extreme severity of the winter. As suon as the frost is out in the spring, remove the covering and loosen the surface around the plants, which when large enough may be transplanted to the flower-garden where they are to remain. The seeds of some species of Hardy Peremials often lie in the ground for six or eight months before germinating, so that patience with them is often unexpectedly rewarded.
ARABIS, OR ROCK CRESS (P)-The earliest, prettiest, spring flower. The spreading tufts are covered with a sheet of pure white flowers as soon as the snow disappears. Unequaled for rockeries or edgings; withstands the drought and is always neat. Pkt., 10c; 1/4 0z., 30c.

AGERATUM (A) - A plant that blossoms continuously all summer in the garden and makes a pleasing contrast of color with more brilliant varieties. Pkt., ic; 1/A 0z., 15c.

ALYSSUM (SWEET). (A)-A very pretty plant for beds, vases, baskets, edgings or rock work. Sweet scented and blooms profusely all summer. Pkt., sc; oz., 25c.

If you want some fine Asters, order Hohenzollern.

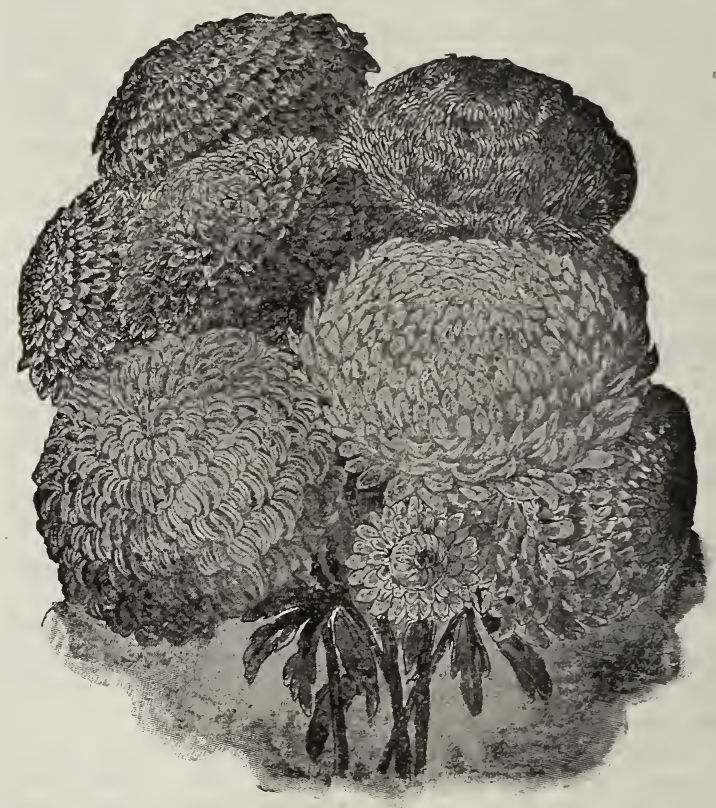

ASTERS

GIANT COMET, OR OSTRICH PLUME (A)-Are thrifty growers, 15 inches high, bearing immense long. stemmed flowers, composed of long, wavy petals, like Jap. anese Chrysanthemums.

Crimson, 2 ft.

Dark Blue, 2 ft.

Light Blue, $2 \mathrm{ft}$.

Rose, 2 ft.

White, 2 ft.

All Colors Mixed

$1 / 4$ oz., 40c; pkt., $10 c$ $1 / 4$ oz., 40c; pkt., $10 \mathrm{c}$ $1 / 4$ oz., $40 \mathrm{c}$; pkt., $10 \mathrm{c}$ $1 / 1$ oz, 40c; pkt, $40 \mathrm{c}$ $1 / 4$ oz., 40c; pkt., ;uc

NEW “CREGO GIANT" ASTER (A)-The "Giant" Crego" is distinct in every way, and its magnificent flow. ers, often 6 inches in diameter, are fully equal to Chrys. anthemums. They have rare beauty of form and brilliant coloring, are very vigorous, and free flowering; blooms are borne on long stems.

White …........................................ 02 50c; pkt., 15c Pink …....................................... 50c; pkt., $15 \mathrm{c}$ Rose …......................................... 50c; pkt.

ASTER (CHINESE SINGLE) (P)-These are exceedingly showy and excellent in cutting for vase decorations. The large, brilliant, daisy-like flowers with yellow centers are produced in profusion. Hardy iperennial. Finest Mixed, 2 ft., $1 / 4$ oz., 40c; pkt., 5c. 


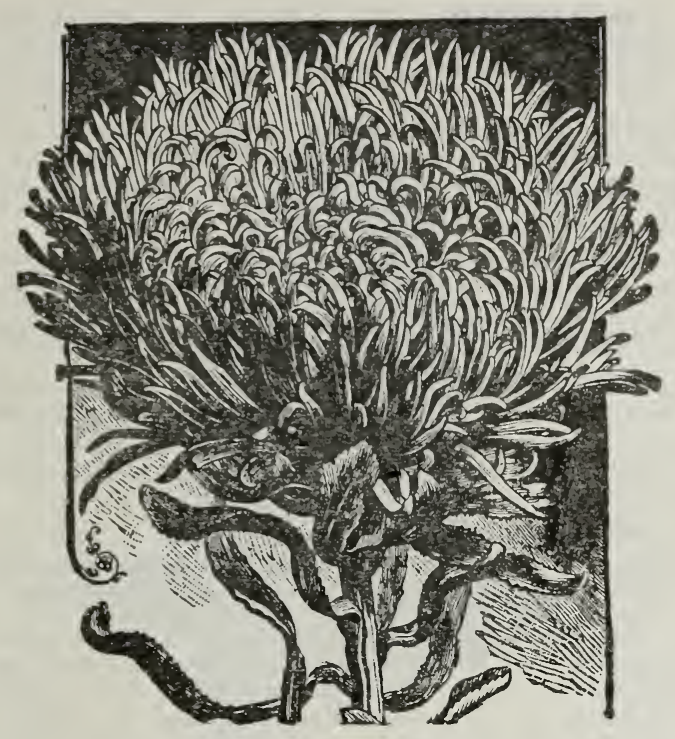

Hohenzollern Aster

HOHENZOIIERN ASTER (A)-The finest type of the Giant Comet, or Ostrich Feather type of Asters. Much larger than the Giant Comet. the petals longer and more curled and iwisted, and produced in greater abundance. Borne on long stems, which makes them cut flowers par excellence. We hare them in separate colors.

White

Light Blue .................................... $1 / 8$ oz., 40c; pkt., 10c Dark Blue …....................................1/8 oz., 40c; pkt., 10c Pink .............................................. $1 / 8$ oz., \&0c; pkt., 10c Rose Lavencler ......................................... $1 / 8$ oz., 40c; pkt., 10c All Colors Mixed ..........................1/8 oz., 40c; pkt., 10c

BALSAM (A)-Unrivaled for the great variety of color and size of flower; includes all of the most desirable shades and colors; no finer mixture can be obtained. Pkt., 10c.

BACHELOR'S BUTTON, OR CENTAUREA CYANUS (A) - A hardy annual, easily cultivated. Has recently been greatly improved, and now produces handsome flowers of a great variety of rich colors. Borne on tall, branching stems, with but little foliage. Striking and handsome. Pkt., 5c; oz., 25c.

BALLOON VINE (LOVE-IN-A-PUFF) (A)-A rapid growing annual climber; succeeds best in light soil and warm situation; flowers white; seed vessels look like min. iature balloons. Pkt., כc.

BEGONIAS (P) - Begonias are among the most beautiful of flowering plants, especially adapted to pot culture. Mixed, pkt., 20c.

CANARY BIRD VINE (P) -A beautiful climber; flowers a bright golden yellow, bearing a fanciful resemblance to birds with expanded wings. Pkt., 5c; $1 / 4$ oz., 15 c.

CANDYTUFT (A)-Mixed, many fine shades. Pkt., 5c; oz., 20c.

CANNA (FRENCH MIXED) (P)-Ornamental, tropicallooking plants of easy culture; large and beautiful flowers. Hardy perennial. Pkt., 10c; oz., 35c. For Canna Bulbs, see Plant Department.

CALENDULA (POT MARIGOLD) (A) - Very hardy annual, one foot high, blooming freely practically the whole year round. Is of the easiest culture and is desirable for rather inferior soils, where less sturdy flowers do not thrive. A medicinal extract resembling arnica is matse from the flowers. Pkt., 5c; oz., 20c.

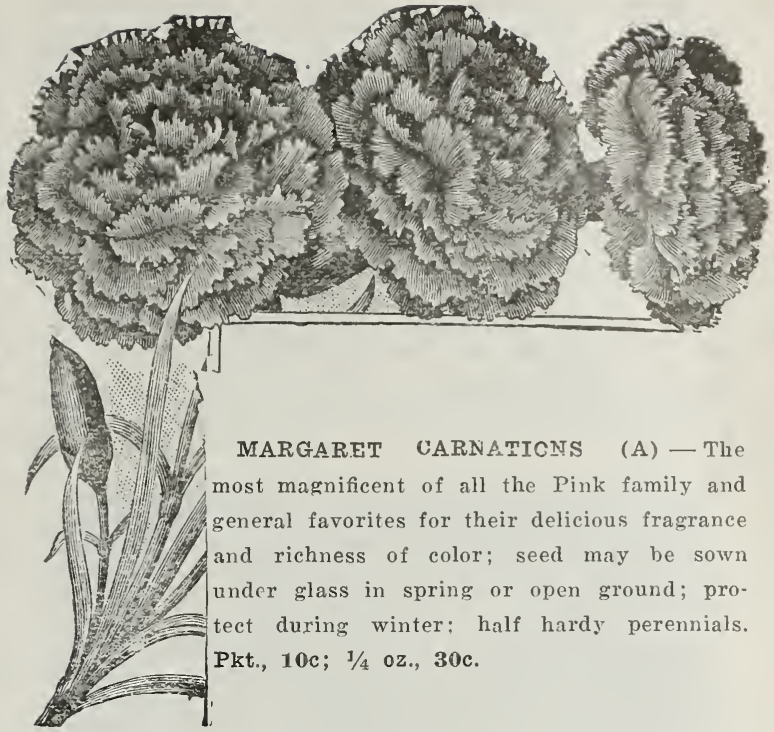

CALLIOPSIS (A) -A quick growing annual. The flowers are placed on graceful wavy stems and in color run through all the shades of red and yellow; foliage dainty: useful combined with other flowers. Pkt., 5c; $1 / 4$ oz., 20c.

CENTAUREA IMPERALIS (ROYAL SWEET SULTAN) (A) -The finest of all Sweet Sutlans; the plants are very strong and bear giant flowers on stiff, long stems; excellent for cutting and lasting, when cut, unusually well. Mixed, pkt., 10c; $1 / 2$ oz., 50c.

COREOPSIS (IANCEOLATA) (P) -A perennial, blooming the first year; flowers rich yellow, single; very fine for cutting. Pkt., 10c; $1 / 4$ oz., $40 \mathrm{c}$.

\section{cosmos}

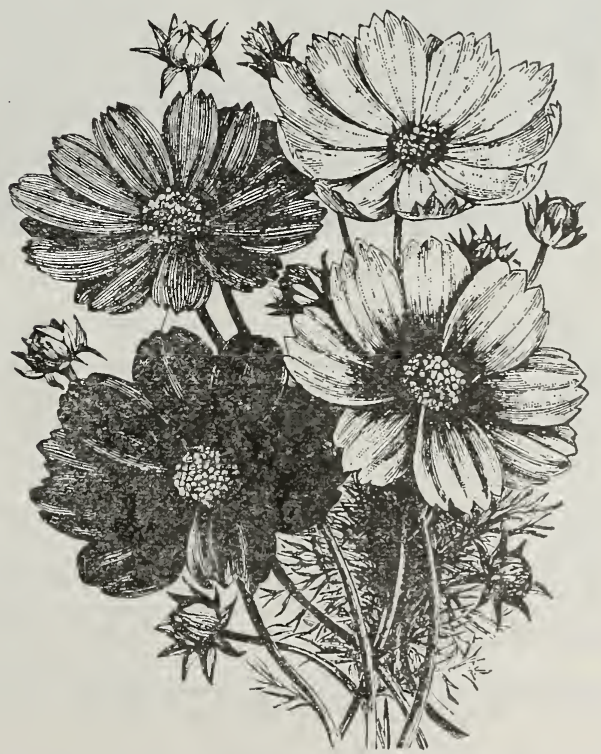

COSMOS (A) -A strong grower, having clegant foliage, and for tall blooming has no superior. Seed grown in March or April and transplanted to open ground will produce plants three to five feet high by September, which thereafter, until November, will yield hundreds of blossoms three inches across; various shades. Pkt., כc. 
CHRYSANTHEMUM (A)-The Annual Chrysanthemums are rapidly coming to the front, both as greenhouse and garden plants; they should not, however, be confounded with the Japanese perennial kinds that are being so widely introduced; the annuals have recently been greatly improved. Pkt., 5c and $\mathbf{1 0 c}$.

COLUMBINE, OR AQUILEGA (P) - $A$ delightful hardy perennial, growing about two feet high, and splendid for permanent beds and borders. Thrives in partial shade and under the spray of a fountain, or other moist location. Bears exquisite blossoms of clear blue, white, rose, yellow, pur 3 and striped. Single mixed, pkt., 5c; oz., 25c. Double mixed, pkt., 10c; oz., 35c.

CELOSIA (COXCOMB) (A)-Free blooming annuals, growing best in light soil not too rich. They make splendid border plants and are attractive for pots. Mixed. Pkt., 10c.

CLARKIA (A)-Handsome, free flowering annuals of easy cultivation. Produce a fine effect massed in beds. llowers are very bright and attractive. Double mixed. Pkt., sc.

COBAE SCANDENS (A)-One of the handsomest and most rapid growing of the annual climbers. It climbs thirty feet in a season. The flowers are bell shape and of a purplish lilac color. Very prolific and perfectly hardy. The vine is always clean of insects. Mixed. Pkt., 10c; $1 / 4$ oz., 20c.

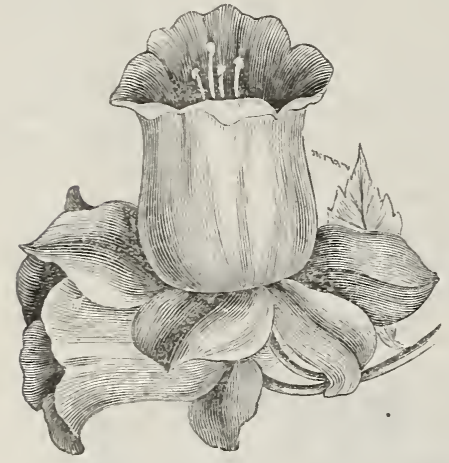

CAMPANULA, OR C A N E R U R Y BELLS (P) - Very ornamental gar de $n$ plants of the easiest culture; hardy bien. nial, two and a half feet high, producing large, nodding and charming bell-shaped flowers of many ex. quisite shades. Pkt. 5c; $1 / 4$ oz., 50c.

CYPRESS VINE, OR IPOMOEA QUAMOCLIT (A)A climber of rapid growth, having handsome, fernlike foliage and a profusion of bright, attractive flowers. Mixed. Pkt., 5e; 1/4 oz., 15c.

DAHIIA (P) - But few people know Dahlıas can be raised from seed and will bloom the first year. The. seeds germinate as easily and certainly as Zinnias, and from the very first development are strong, and sturdy little plants. Plant them in a shallow box or pan early in March or April, transplant them carefully as their growth demands, and keep the sil moderately moist. When al danger from frost is over, nlant them in the bed or border in the garden, and from then on they will prove no more trouble than if the tubers had been used instead of seed. Double Mixed, Fist.

Single Mixed, rkt

Cactus Dahlia, Irixed, pkt

$10 \mathrm{c}$

SHASTA DATSY (P) -A most remarkable new flower, originated by I,uther Burbank, of California; bears flowers of the snowiest white, with vellow renters; blooms the first season and hould be sown in boxes early and trans. planted. Pkt., tic.

DIANTHUS (CHINESE PINK) (B)-Mixed: many dis tinct and beautifully marked varieties. Pkt., ic; $1 / 1 \leq 2$., 25c

DIGITAIIS (EOXGLOVE) (P)-Handsome ornamental hardy plants of stately growth. The seed, though sinall, germinates readily and the nlants succeed well even in poor soil if given a half shady location. The spikes are often 3 to 5 feet long and thickly strung with scores of thimble-shaped flowcrs. Mixed colors. Pkt., ic.
DIMORPHOTHECA AURANTIACA (A)-The Golden Marguerite. A rare and extremely showy annual from South Africa which has become a great favorite on account of its very easy culture and beautifully colored flowers. Its Marguerite-like blossoms, produced in great

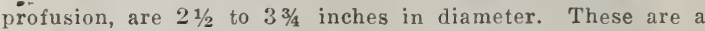
unique glossy rich orange gold, which brilliant coloring is rendered more conspicuous by the dark disk surrounsling the black zone. Pkt., 10c.

ESCHSCHOLTZIA (CALIFORNIA POPPY) (A)-The State Flower of California; an annual of rich, rare tints of yellow and orange. About a foot in height, beautiful foliage and large, poppy-like flowers. Pkt., 5c; $1 / 4$ oz., 20c.

FOUR O'CLOCK (MIRABILIS) (A) - Is also called Marvel of Peru. A handsome, free-flowering, sweet-sceated plant. They open their blossoms about four o'clock in the afternoon, hence their name. IIardy annuals. Choice mixed varieties. Pkt., כc; oz., 15 c.

FORGET-ME-NOT (MYOSOTIS) (P) -A modest little flower, to friendship ever dear. (See also Flowering Plants.) A pretty, trailer with blue flowers. Pkt., 10c.

GERANIUM (P) - Comporatively few are aware that Geraniums may be grown easily from seed and flower the first season if sown early. This is the best way to secure Geraniums, as they will frequently reward the cultivator with charming new varieties. In fact, propagation by seea is the only way to obtain new rarieties. Pkt., 15c.

GODETIA (A) - An attractive, hardy annual deserving more extensive cultivation. The plants bloom profusely and bear showy flowers of rich and varied colors, one and one-half inches. All colors, mixed. Pkt., Jc.

GOURDS (ORNAMENTAL) (A)-Rapid growing, interesting annual climbers with handsome foliage and singular shaped fruit. Mixed varieties. Pkt., 10c; oz., 20c.

GYPSOPHILA, OR BABY'S BREATH (A)-A pretty, free-flowering plant. Fine for bouquets. Pkt., Jc.

HOLLYHCCKS (P) - These fine, old-fashioned perennials are most striking when plant 1 ed in groups or long rows: their variety of color is wonderful. When plants are once obtained they last for several seasons. Double, mixed colors. Pkt., 10c.

one lores the delightiol Every grance and beauty of the Heliotrope, but few know that it can be raised from seed as easily as the Verbena. To insure a long period of bloom seed should be sown early indoors. Per pkt. 10c. Heliotrope

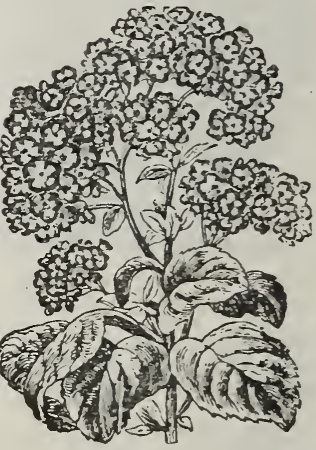

LOBELIA (A) - $\lambda$ very valuable and beautiful dwarfgrowing plant, delicate drooping habit and profusion of charming little blue and white flowers. Choicest mixed. Pkt., 10c.

LARKSPUR, OR DELPHINIUIM (A)-One of the mnst showy and useful plants, making useful border flowers. Pkt., sc; oz., 20c.

MOON FLOWER, OR IPOMEA, MEXICANA GRANDIFLORA (A) - Rapid growing climber, belonging to the Morning Glory family. The flowers are large, waxy white and very showy. Pkt., 10c; $1 / 4$ oz., 20c.

MORINING GIORY (A)-New Japanese: the surpass ing charm in this grand variety lies in the entrancing beauty and gigantic size of the flowers. Pkt., 10c;0z., $20 \mathrm{c}$.

MORNING GLORY (A)-Tall, fine mixed: a great variety of colors of the popular old-fashioned sorts. Pkt., 5c.

MINUIUS (P)-Moschatus, or Musk Plant. Cultivated for its rich musk odor. Should have a rich soil and ams!e moisture. Hardy and perennial. Pkt., 10c. 
MARIGOLD (A) - Weli known, extremelv showy garden plant, with handsome double yellow and brown flowers of varied shades; succeeds in good garden soil. Annual. Pkt., sc; Oz., 3.sc.

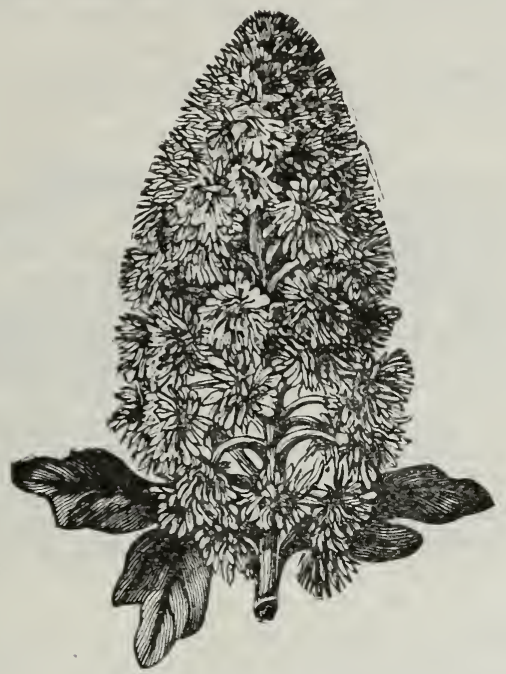

Mignonette

MIGNONETTE RESEDA (A) - A well-known fragrant favorite and no garden is complete without a bed of Mignonette. Sowings are made in April and again in July, will keep up a succession from early summer until frost. Pkt., 5c; oz., 25c.

NASTURTIUM, TALL OR CIIMBING (A) -A very well-known ornamental, profuse flowering plant, adapted for rock work. The seeds, if picked young, are an excellent substitute for capers. Pkt., Jc; oz., 10c; 1/4 1b., 25c.

NASTURTIUM. TOM THUMB OR DWARF (A)-When planted in beds or masses the brilliant eftect of these splendid flowers is scarcely surpassed by any of our finest bedding plants. Pkt., כ̇c; oz., $10 \mathrm{c}$.

NIGELIA-LOVE IN A MIST, OR DEVII IN TTTT BUSH-DAMASCENA (A) - A compact, free-flowering plant, with finely cut foliage curious-looking flowers and seed pods; of easy culture, growing in anv garden soil; hardy annuals; blue and white mixed. One foot. Pkt., 5c.

NICOTIANA-AFFINIS (Tukerose-Flowered Tobacco) (A) -Delightfully sweet-scented, pure white tubular flowers, blooming continually; annuals; two to three feet high. Pkt., 10c.

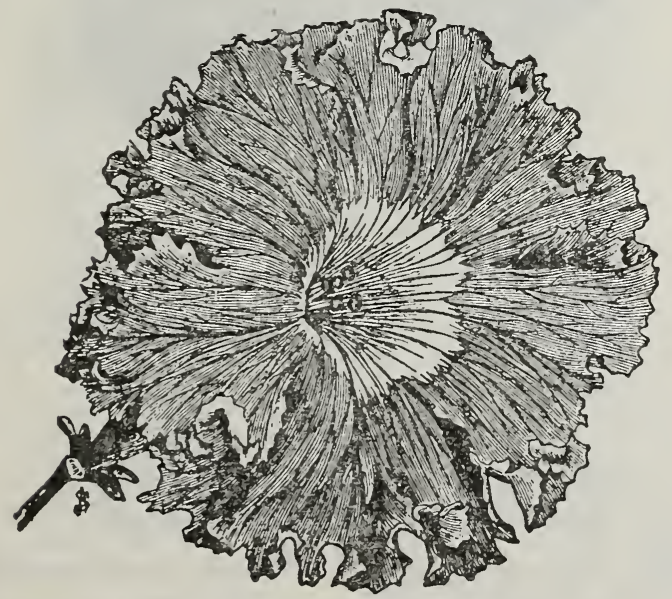

PETUNIA (A) - For outdoor decoration or house culture few plants are equal to this class. They commence to bloom early and continue to flower through the summer. Give them a rich soil and sunny place. Fine mixed, pkt., 5c; $1 / 8$ oz., 25c. Fancy mixed. pkt., 10c.
PENTSTEMON (P)-Handsome, half hardy, herbaceous perennials about two feet high and much in favor for bedding out. Flowers bell-shaped or tubular, an inch and a half long, borne in racemes or spikes, white and various shades of rose and purplish red striped with white. Mixed. Pkt., 10c.

PORTULACA. OR ROSE MOSS (A)-Brilliant, dwarf annuals, only six inches high, luxuriating in warm situa tions and blooming profusely from early summer to autumn. For low beds and masses of color, from spring until frost, they are indispensable; colors range through innumerable shades of red, yellow, pink, striped, white, etc. Mixed. Pkt., 5c; $1 / 4$ oz., 20c.

PRIMROSE (CHINESE) (P) - The culture of these lovely flowers is much easier than most people think Our mixture includes not only all the choicest colors of the single flowering Primulas in all their dainty shades, but it comprises also seed saved from hybridized flowers, and will produce a number of double flowers and the new blue Primula. Pkt., 10c.

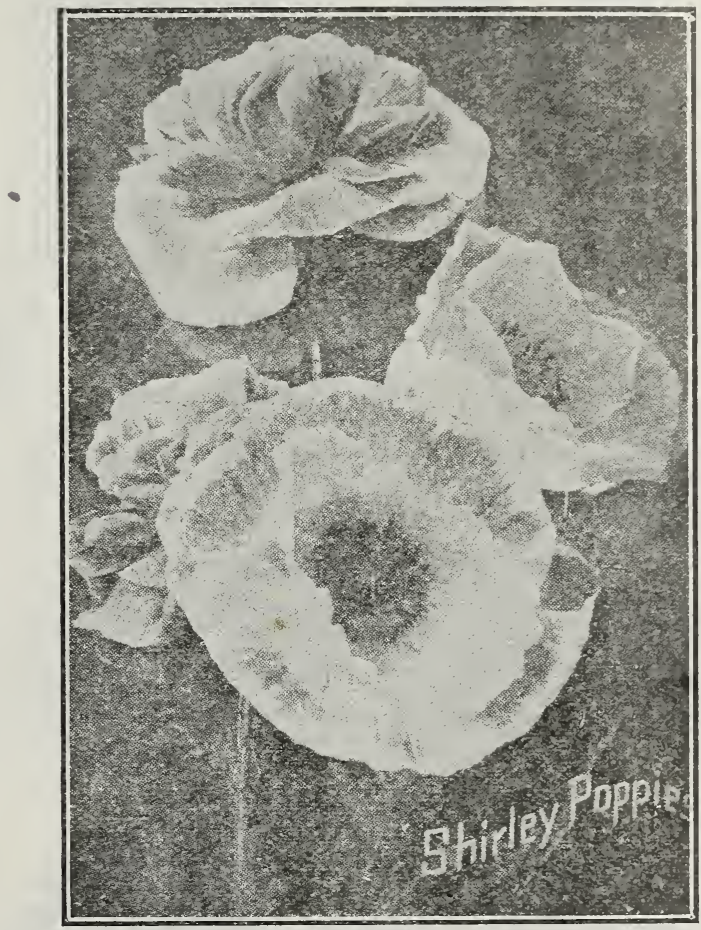

\section{POPPIES}

Probably no class of plants enjoys greater popularity and is more widely grown than the annual poppies; this is especially true of the single varicties. They are easily grown, and should be sown in beds or wild patches, in the fall or early spring, where they will grow high above the grasses on tall graceful stems.

CALIFORNIA POPPY (A)-See Eschscholtzia. Pkt., 5c; 0z., 20c.

SHIRLEY (A)-The most beautiful tyne of poppies, having soft, hairy foliage, and a variety of single blossoms in white, pink, lavender, purple, red and scarlet. Free blooming, and fine for bedding or tall border. Pkt., 5c; oz., 25c.

SINGLE, MIXED (A) - All single varieties and colors. Pkt., 5c; oz., $20 \mathrm{c}$.

PEONY FLOWERED (A)-Large, showy double, glohular flowers: mixed colors. Pkt., 5c; oz., zoc.

ICEI,AND (P) -A graceful, delicate variety, with dark red single flowers, the petals resembling crumpled tissue paper. The plant is low-growing, but the stems are long and slender. Pkt., 10c; $1 / 4$ oz., 40c.

ORIENTAI POPPY (P) -One of the showiest of perennials with enormous scarlet flowers with purple centers. The leaf is long and deeply cut and clothed with white bristly hair. Beautiful among shrubs, roses and other perennials. Pkt., 10c; $1 / 4$ Oz., 25c. 


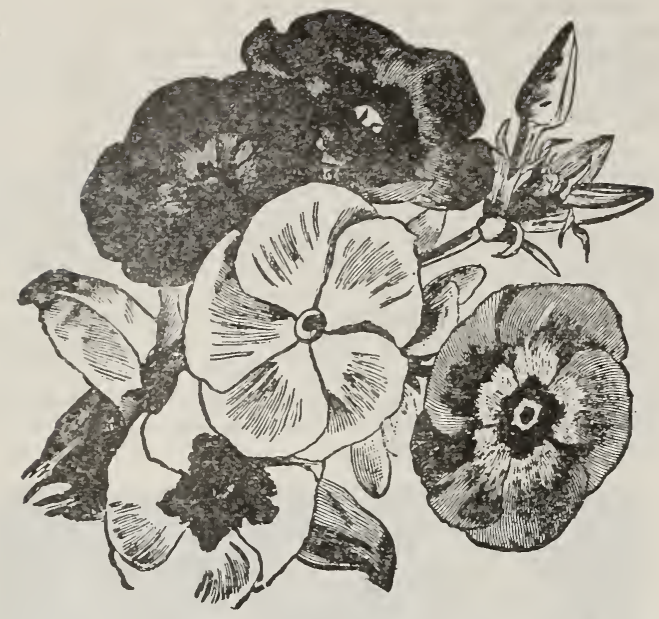

PHLOX DRUMMONDII (A) - Of all summer-flowering annuals the varieties of Phlox Drummondii are unques. tionably one of the most brilliant and satisfactory. See may be sown in the open ground any time after danger from frost is past, and in a few weeks the beds or borders are aglow with their brilliant coloring and remain so until cut down by frost. For early flowering they should he started indoors or in a hotbed. Mixed colors. Pkt., 5c; $1 / 4$ 0z., 50c.

\section{Pansies}

PANSY (VIOLA ARICOLOR) (P) - A half-hardy peren. nial, growing four to six inches high and probably the best known and among the most popular flowers in cultiva. tion. It thrives best in a moist, shady location, and in rich, loamy soil. Seed should be sown in the autumn for early spring blossoms, or can be sown early in the year for good flowers later in the spring.

\section{Steele's Mastodon Pansies}

For years the Steele Pansy Gardens have grown our Giant Pansies. These have been carefully reselected and bred up to their present surpassing excellence, and for giant size, substance, form and coloring we have never seen Pansies to compare with them. Named varieties and special strains are grown separately and the seed collected by hand and carefully blended into what we believe to be the finest mixture ever offered. Price, per pkt., 25c.

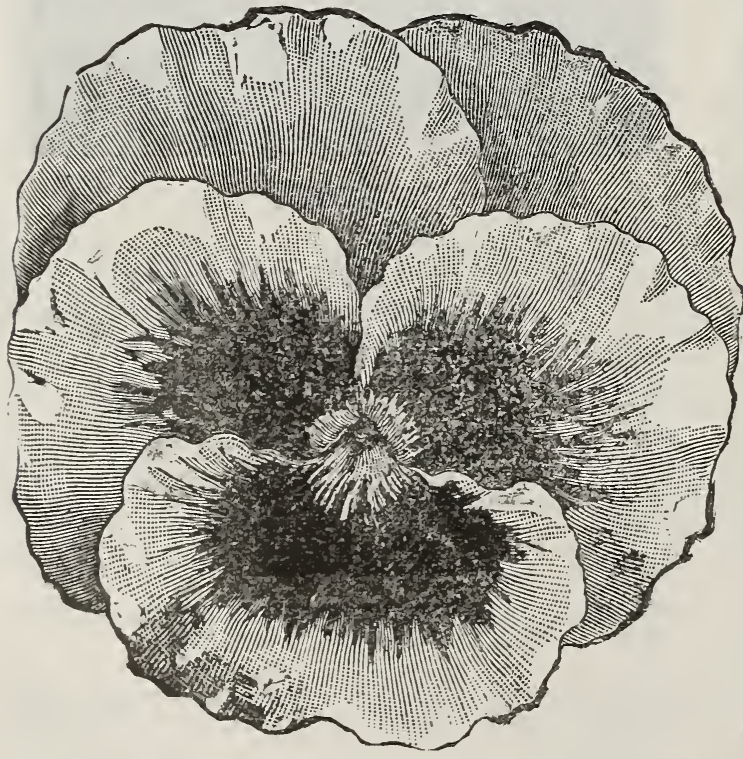

TRINEARDEAU GIANT, MIXED-A splendid mixture of various shades and markings. The blossoms are perfectly round and are blotched at the base of three to five of the petals. Pkt., 10c.

FINE MIXED-A fine assortment of colors. Pkt., sc.
RICINUS, OR CASTOR OIL BEAN (A)-Ornamental plants of steady growth and picturesque foliage with brilliant colored fruit, producing a sub-tropical effect; fine for lawns, massing or center plants for beds. Pkt., sc; oz., $20 \mathrm{c}$.

SCIIZANTHUS (A)-Hardy annuals, growing one and one-half to two feet high and covered with bright, showy, butterfly-like blossoms. Large flowering. Mixed. Pkt., $10 \mathrm{c}$.

SWEET SCABIUS, OR MOURNING BRIDE (A)Free-flowering annuals; colors, white, carmine, lilac, maroon, etc. Very effective for garden decoration and valuable for cutting. Dwarf or tall double mixed. Pkt., бc; $1 / 4$ oz., $15 \mathrm{c}$.

SALVIA, OR FLOWERING SAGE (P) - $A$ tender perennial blooming the first season from seed and growing two to three feet high. The blossoms are borne on long stems in racemes or spikes, and are fragrant. The plant forms a bunch and blooms profusely during the whole summer and fall. Fine mixed. Pkt., 10c.

SMILAX (BOSTON IVY) (P) - Uharming, tender, perennial climber for greenhouse or window gardens. The foliage and stems are of a pleasing light green; very graceful; excellent for decoration. Fkt., 10c; 1/4 0z., 25c.

SCARLET RUNNER (A)-Ornamental and useful; the vine is graceful; flowers are of a brilliant scarlet and the beans are of an excellent quality, either when shelled or in a d̈ry state. Pkt., 5c; 1b., 25c.

SNAPDRAGON, OR ANTIRRHINUM (P)-One of the most useful and showy of border plants. Of almost every color, and striped as beantifully as Carnations. They have recently been much improved and are now really magnificent. Hardy perennial. Finest mixed. Pkt., sc.

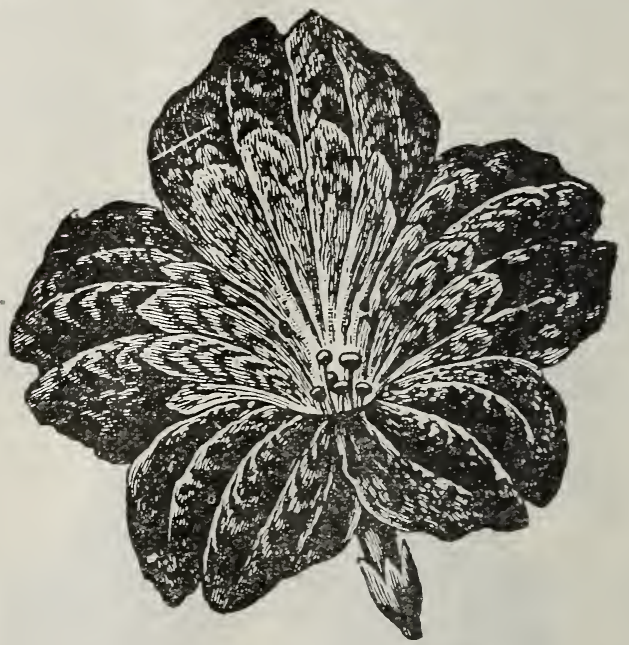

\section{Salpiglossis (Velvet Flower)}

SALIPGLOSSIS (A)-The quaint, funnel-shaped flowers somewhat resemble those of the Petunia; beautiful range of colors. Pkt., 5c; $1 / 4 \mathrm{Oz}$., $25 \mathrm{c}$.

LARGE FLOWERING, 10.WEEK STOCK (A)-This is the leading class for bedding out or summer-blooming. All varieties, mixed. Pkt., 10c; $1 / 4$ oz., 50c.

SWEET WILLIAM (P)-A well-known, attractive, freeflowering, hardy perennial, producing a splendid effect in beds and borders with rich and varied flowers. The demand for separate colors has induced us this season to offer several of the best and most distinct flowering sorts. Mixed. Pkt., כc; oz., 25c.

WILD FLOWEP GARDEN MIXTURE (A)-A garden is not complete without a bed of this mixture of flowering annuals. A package will sow a bed about two by ten feet, and if sown early in the spring will furnish confeet, and if sown early in the spring will furnish con-
tinual bloom throughout the season. Pzt., 10c; oz., 50c. 
VERBENA (A) - Very few annuals will make such a gorgeous display during the summer months or furnish more flowers for cutting, than the Verbenas. Start seed in the house or under glass early in the spring and transplant after three or four inches of growth. They flower in July and continue strong and healthy until destroyed by frost. Fine mixed. Mixed, pkt., 5c; $1 / 4$ oz., 20c.

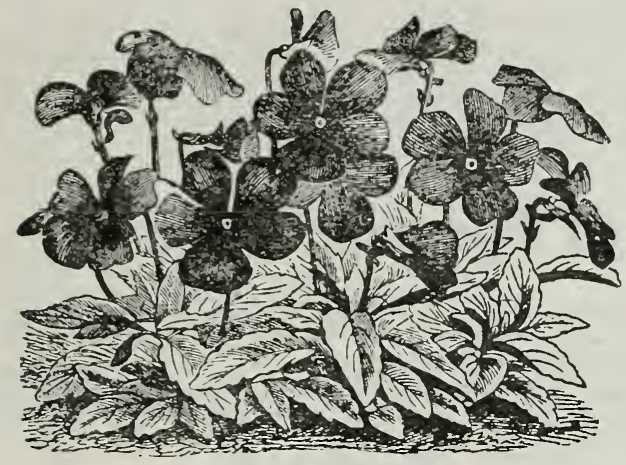

Violets
VIOLETS (P) -Viola Odorata is the well known English Violet, a free-flowering, hardy perennial. Easily grown from seed, though somewhat slow in germinating; succeeds best in partially shaded moist places. Choice mixed. Pkt., 10c.

WALL FLOWER (P) - Produces spikes of beautiful, ex ceedingly fragrant flowers. Half-hardy perennial. Mixed. Single, large flowering. Pkt., 5c.

WILD CUCUMBER (A)-A well-known vine, common in many sections, and the quickest climber known for covering verandas, old trees and houses, trelises, etc. never suffering from the heat, but retaining its fresh lirely green color; never infested with insects and very profuse in bloom. It will sow itself and come up in the same place. Pkt., 5c; 0z., 20c.

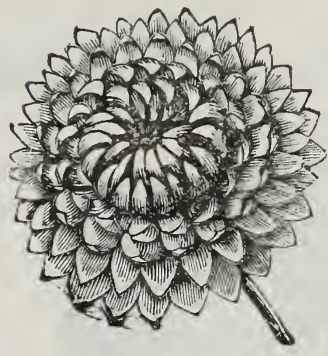

ZINNIAS (Youth and Old Age) (A) - Is one of the most brilliant and showy annuals, and has long been a general favorite. The seed can be sown early in the hotbed and transplanted, or sown later in the open ground. They come in flower early in the summer, and keen

frost. Choice mixed. Pkt., 5c.

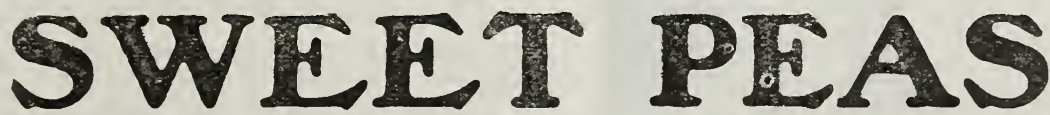

No garden is too small for a row of Sweet Peas and no estate, however extensive or magnificent, should fail to include many varieties of this most popular flower. Hundreds of varieties have been offered for sale by seedsmen but owing to recent marked improvements many sorts are decidedly inferior and have been dropped from our list.

CULTURE-Early in spring make a trench three to four inches deep in rich, mellow soil, so arranged that no water can stand in it and plant the seed in the bottom, covering at first only one inch deep. Sweet Peas, particularly the white seeded sorts, are often a little difficult to start. If the soil is too dry they will remain a long time without germinating; if it is too wet and cold they will not sprout at all. In soils at all heavy, or composed largely of clay, put about one inch of sand in the bottom of the trench and sow the seed $n$ this, covering with more sand. Cover the row with a board to shed the rain and protect the soil from the hot sun but remove this as soon as the young plants appear. When the plants are two inches high, criltivate and as they grow gradually fill up the trench. When the plants are about five inches high it is desirable to furnish some support for the vines to run upon. The roots should not be allowed to become too dry. Water applied thoroughly once or twice a week, preferably early in the morning or in the evening, is usually better than light sprinkling more frequently. The blooms should be picker before they form pods or the plants will soon stop flow. ering.

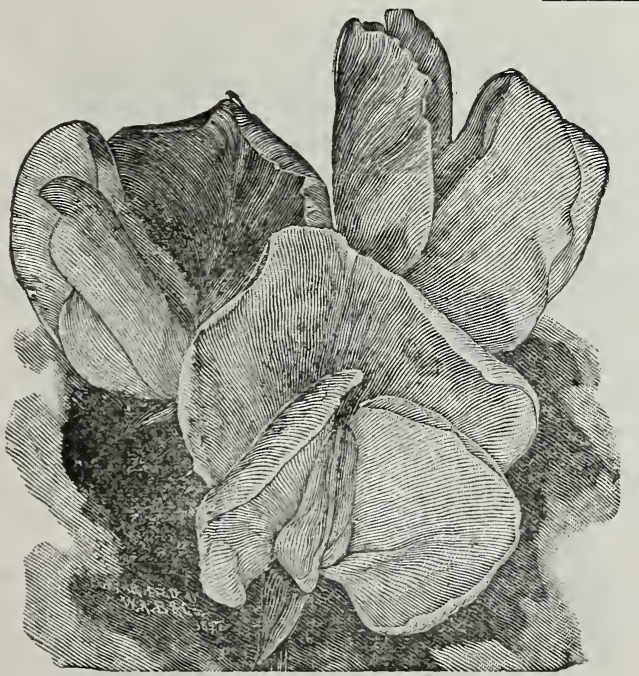

Select list of fine Flowering Sweet Peas, the best of their color and type

PRICES: 5c per pkt.; 15c per oz.; 1/4 lb., 35c; per lb., \$1.10, postpaid.

\section{Light Pink}

STELIAA MORSE-Flowers of a peculiar warm salmonpink. A combination yellow and pink which is distinct and very attractive.

LOVELY-The most beautiful shades of soft shell-pink, changing to very light rose at the outer edges. Grand flowers of large size.

MISS WILIMOTT-Described as an "orange-pink" delicately shaded rose. Enormous flowers, borne erect on long, stiff stems.

PRIMA DONNA-A most beautiful bright shade of blush-pink. Flowers of large size and finest form.

\section{Cream or Light Yellow}

HON. MRS. E. KENYON-Rich, primrose. A bold, giant flower. The best in this shade.

\section{Purple and IMaroon}

BLACK NIGHT-One of the darkest varieties.

COUNTESS CADOGAN-Large flowers. The color effect is that of a bright blue.

OTHELIO-A deep maroon self-color; very large.

Striped and Variegated

SENATOR.

PRINCE OF WALES.

\section{Lavender and Blue}

NAVY BLUE-A true blue.

COUNTESS OF RADNOR-Self-colored in a very dis tinct and beautiful shade of lavender. 
SWEET PEAS-Continued

\section{Orange and Salmon}

HENRY ECKFORD-A distinct orange scarlet of the finest form and largest size; as beautiful under artificial light as in daylight.

\section{Red Standards, White Wing}

BLANCHE FERRY-Bright pink standard and nearly white wings.

\section{Shades of Red}

KING EDWARD VII-A lovely, intense crimson. A truly giant-flowering variety. The finest crimson to date. Strong stems and growth.

MAJESTIC-Fiery carmine, wings rose-madder.

PRINCE OF WALES-Rose pink.

\section{White}

BLANCHE BURPEE- $\Lambda$ splendid pure white variety. While not so profuse a bloomer or as hardy a plant as the Emily Henderson the flowers are fine.

EMILY HENDERSON-A bold, well formed, clear white flower. Wings broad and well expanded. An early and wonderfully free and persistent bloomer.

\section{Sweet Peas--Countess of Spencer Type}

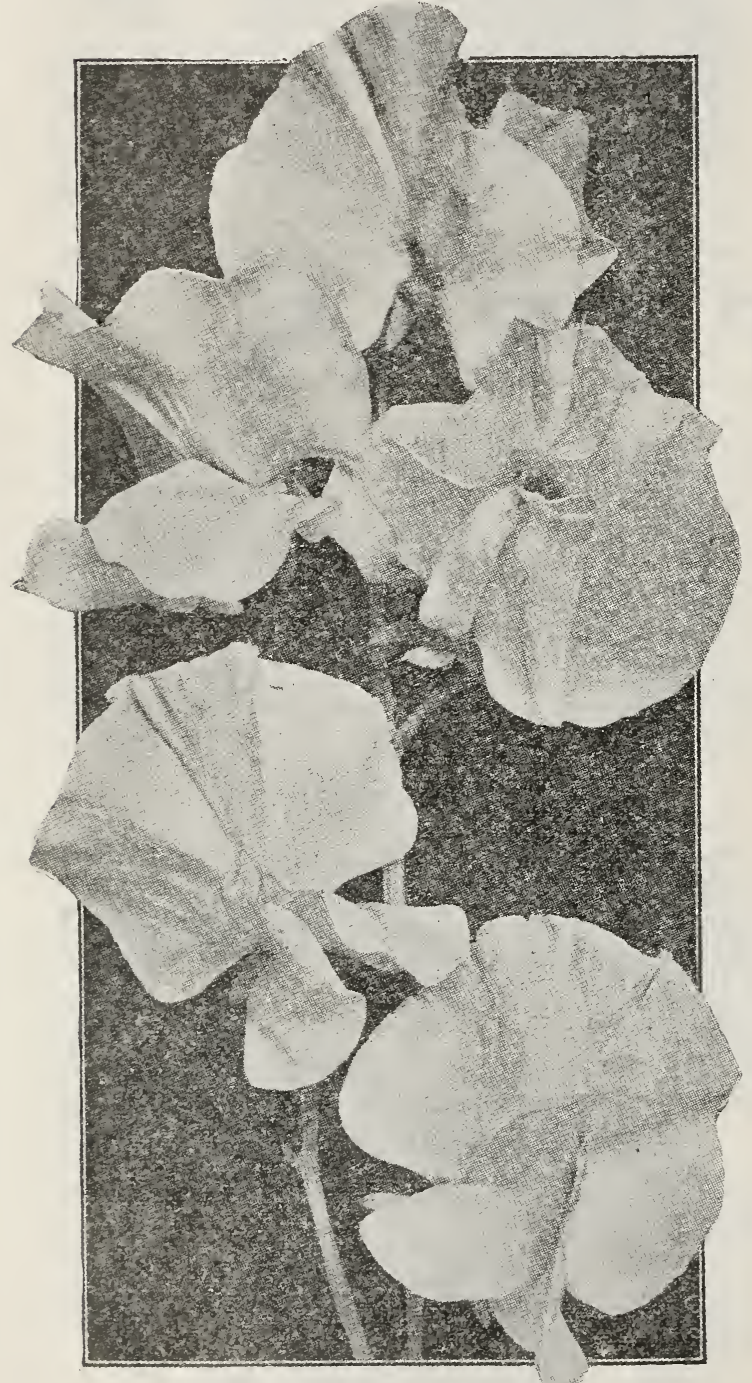

SWEET PEAS

COUNTESS OF SPENCER TYPE-This new strain is very popular as they produce flowers usually from onequarter to one-half agnin larger than the old type of sweet peas, besides the standards and wings are flnted and gracefully formed, thus the appropriate name of Orchid Flowereu
Sweet Peas. Our stocks are true selected type, and as they are not as free flowering as the old-fashioned sweet peas, are consequently higher in price.

KING EDWARD VII SPENCER-The standard is a deep, rich carmine scarlet of glossy effect. The wings are also carmine scarlet, and on the reverse side are also deep rose carmine. Pkt., 10c; 0z., 25c.

FLORENCE MORSE SPENCER-Delicate blush with pink margin. Very large open wavy form of the best Countess Spencer type, witl longstems and four blossoms to the stem. Perhaps better described as a light pinked gedCountess spencer. Pkt., 10c; oz., 25c.

PRINCESS VICTORIA-White blush and pink-edged Spencer. Pkt., 10c; oz., 25c.

QUEEN VICTORIA SPENCER-The flowers are txtremely large, of the true waved Spencer type, and have a most pleasing color effect. The background is quite a deep primrose flushed with rose. The flowers are all of good substance, borne three and four on a stem. Pkt., 10c; oz., 25c.

WHITE SPENCER - Flowers absolutely pure white. Standard is waved, crinkled and fluted; three to four blossoms to a stem. Stems 12 to 15 inches in length. Pkt., 10c ; oz., 25c.

MRS. HARDCASTLE SYKES, OR PALE PINK SPENCER-Flowers of purest pale pink. Pkt., 10c; oz., $25 \mathrm{c}$.

PRINCE OLAF-The bold effective flowers are striped and mottled bright blue on white ground: of good size, with erect expanded standard; the flowers are borne frequently four to the stem. It is a very profuse bloomer. Pkt., 10c; oz., 25c.

IVY MILLER-It is a bluish white, with a little more color on the back of the standard and it is Picotee edged variety, having a distinct edge of darker color around the standard and wings. Price, pkt., 10c; ob., 25c.

DAINTY SPENCER-White suffused and edged with pink; large and of Spencer form; very free blooming. Price, pkt., 10c; oz., 25c.

PRIMROSE SPENCER-The best Primrose Sweet Pea yet developed. True Spencer type, large wavy petals, frilled at edges; clear, distinct color. Pkt., 10c; oz., 25c.

FLORENCE NIGHTINGALE-Known to be the largest and best Lavender Spencer ret introduced. The standard is unusually large and bold, pronouncedly waved, yet standing erect and broad-frequently measuring two inches across. The color is of a most charmingly soft clear rich lavender, which is enlivened by a very faint sheen of rose-pink. The large well-spread wings are of the same coloring, frilled and well waved. It is practically a selfcolor and bunches beautifully-attracting universal admiration. Pkt., 10c; 1/2 0z., 25c; oz., 40c.

MARIF COREILI-The wings are a pure rich rosecrimson, while the standard shows a tint of clierry-red. The whole effect is that of a brilliant crimson-clear, distinct and most beautiful. The standard is large, round and wavy; the wings are full and inclined to remain boldly outright instead of drooping. The long strong stems usually bear four fiowers each. Plt., 10c; 1/, 0z., 20c; oz., 35c.

SPENCER SWEET PEAS-All varieties mixed. Pkt., $10 \mathrm{c} ;$ 0z., 25c; 1/4 1b., 75c; 1b., \$2.50.

For cultural direction of Sweet Peas, see Page 74. 


\section{Hardy Climbing Vines}

VIRGINIA CREEPER-Has large, luxuriant foliage, which in autumn assumes the most gorgeous and mag nificent color; one of the finest vines for covering trellises, or verandas. Each, 50c postpaid.

CLEMATIS JACKMANNI-This variety, strong growth, hardy nature and rich, deep velvety-purple flowers, is the most satisfactory of its class. Blooms with astonishing profusion. Price, 75c postpaid.

HONEYSUCKLE - Grows rigorously, with yellowish white, fragrant flowers. Price. 50c postpaid.

HOPS- Ire the most rapid orowers of any vine coming from the roots eacli spring. Their rapid growth and large broad leaves cover a porch before the arrival of the hot days of summer. 60c per doz., postpaid.

CINNAMON VINE-This climber is appropriately called Cinnamon Vine. Yery hardy, the stem dyiug down every autumu, but growing again so rapidly as to cover completely any trellis or arbor early in the season. With its heautiful heart-shaped leaves and clusters of delicate :flowers, and most delicious cinuamon odor, is a most desirable cliniber. 5c each, 50c per doz., postpaid.

6MADEIRA VINE-A beautiful rapid Aimber, bearing graceful racemes of fragrant white flowers; very pretty and useful. sc each, 50c per doz., postpaid.

\section{BULBS}

\section{Summer Flowering Bulbs}

There is nothing in floriculture that will give greater satisfaction or produce such grand results as this ceass of bulbs, which includes some of our showiest garden flowers. They are of the easiest culture. Planted in Spring in good garden soil, they flower with great certainty during Summer and Fall. The hardy sorts may remain in the ground over Winter, but tender sorts should be taken up after the foliage dies in the Falls, and the bulbs stored away in a crry, cool place until planting time the next Spring.

\section{Dahlias}

The Dahlia is one of the most popular summer and fall flowering bulbs, and is a general favorite, and should have a place in every garden. The flowers are very showy and gorgeous. The varieties listed by us are exceptionally fine, each one being a gem in itself.

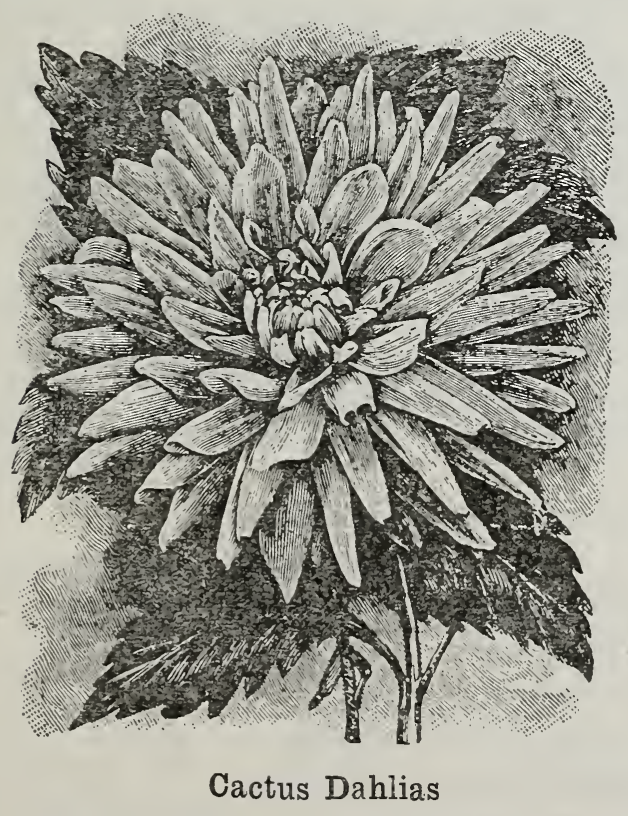

The Cactus forms of Dahlias are exceedingly beautiful, and are hard to excel. They have long twisted petals and embrace nearly all the colors and shades to be found in any of the other types.

\section{Standard Sorts}

BURBANK-Deep clear dark red. An excellent bloomer which never under any circumstances shows the least tendency toward an open center, no matter how dry the weather or poor the soil.

WINSOME-Undoubtedly the gnest white Cactus to date. Flowers are very large and beautiful, with twisted, incurved petals and are borne on long, erect stems, holding the flower up in marked contrast to other wlite Cactus Dahlias.

INNOVATION-The finest bi-colored Cactus Dahlia. The center is of a deep scarlet, the extremities of the petals are white.

KATHERINE DUER-The most beautiful glowing scarlet without markings. The flowers are of immense size, 7 inches across, opening out flat and showing no center, with wide and rounding petals. The plant is a strong grower. Height 5 feet.

KRIEMHILDE-An exquisite shell-pink shading to white in the center. Undoubtedly the finest and most perfect pink Cactus Dahlia to date, and as a cut flower supersedes all the other pink sorts.

Price: Each, 25c; entire six, $\$ 1.25$ postpaid.

\section{Standard Dahlias}

\author{
CRIMSON GIANT-Deep crimson flowers of immense \\ size. \\ HENRY PATRICK-A pure waxy white. It blooms \\ very freely, producing flowers from 5 to 7 inches in \\ diameter.
}

MRS. ROOSEVELT-A most delicate pink flower, immense in size, graceful in form and having excellent stems for cutting. Perfectly double, 6 to 8 inches in diameter.

PRES. F. FAURE-A deep purplish crimson with broad thick petals.

SYLVIA-White shading to soft pink on the outer petals which are of great substance. The flowers measure about 5 inches, are fine in form and full to the center, making it a great shipper. The plant is a strong and healthy grower.

WM. AGNEW-The richest shade of intense, dazzling red. Flowers are large, measuring more than 5 inches in diameter.

$\checkmark$ COLOSSE-A clear yellow exhibition variety. The flowers are very perfect and on long stems.

Price: Each, 25c; entire six, \$1.25 postpaid.

\section{Novelties in Dahlias}

AURORA CACTUS-An attractive soft pink, slightly tipped white, brilliant golden in the heart. One of the best Dahlias for exhibition, being colossal in size, elegant in form, most perfect in type and of the most exquisite coloring.

OTHELLO CACTUS-Dark blood red with a velvety black sheen. An early and free bloomer with stalks long and strong, carrying flowers well above the foliage.

JEANNE CHARMET (Peony Flowered)-Bright pink witl crimson edges. Flower 7 to 8 inches in diameter with long, wide, loosely formed petals. Center covered with short petals. 'Flowers borne on fine long stems. Early and extra fine.

BIG CHIEF (Peony Flowered)-Brilliant cherry-red, margined rich velvety maroon. A strong vigorous grower, producing its immense semi-double flowers, 6 to 7 inches across, on 2-foot stems, in greatest profusion.

Price: Each, 75c; four, $\$ 2.50$ postpaid. 
Gladioli are the most sat isfactory, desirable and popular of all the garden bulbs. Nothing else of the kinr cost so little, grows and blooms so readily in any soil or climate as Gladinli They thrive and bloom with the least care and attention, and make a disnlav

for brillianev and beauty of coloring few bulbs can equal and none surpass. Flarlinli are of the simplest culture. Plant any time from liarch to Tune.

GLADIOLI CHILDSI Finest nixed. This won derful new giant type orig. inated in frermany: is of much stronger growth and large flower than the orig. inal type. By mail, $5 \mathrm{c}$ each, or $40 \mathrm{c}$ per doz.

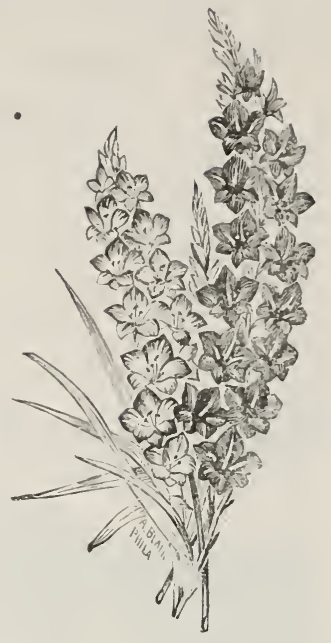

\section{Paeonies}

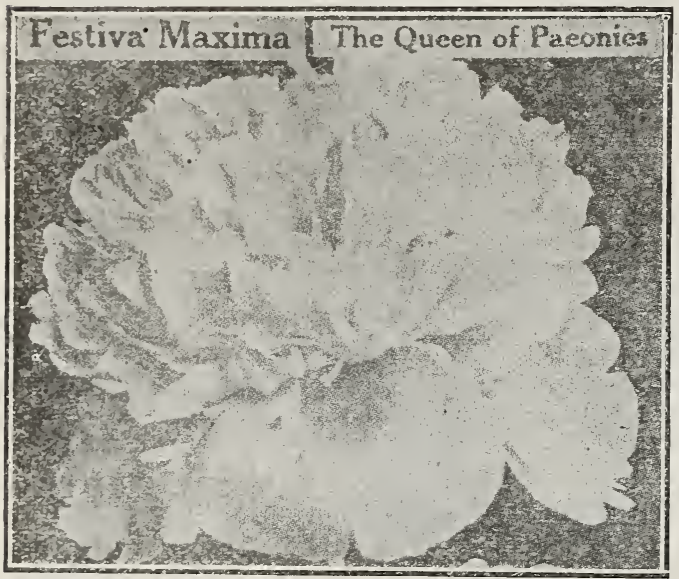

FESTIVA MAXIMA-The best known Peony. Flower of immense size- 7 to 8 inches in diameter-snow-white, with some red spots on the edges of the center petals. Very sweet. Early. Price, postpaid, 60c.

QUEEN VICTORIA-Guard petals milk white, tinted flesh, center creamy white with crimson spots, large globular flower, on stems of medium height, free bloomer, midseason. Price, postpaid, 30c.

M. BOUCHARLET-Bright pink. Of medium size and excellent form. A good grower and of compact hahit. Valuable lawn sort. Midseason. Price, postpaid, 50c.

KOHINOOR-Shell pink, very free, splendid cut flower sort, midseason. Price, postpaid, 30C.

LEE'S GRANDIFIORA RUBRA-Rich red, resembling American Beauty Rose, of enormous size and long stem. One of the latest and best. Price, postpaid, 60c.

OFFICINALIS RUBRA PLENA-This is the old-fashioned red, the most brilliant of all red Peonies. Early and splendid cut flower. Price, postpaid, 30s.

\section{Lilium Auratum}

'The handsomest and best known of the Japan Lilies. Its imniense ivory-white flowers are thickly studded with yellow and crimson spots, while in the center of each petal is a gold band fading at its edges into white; very fragrant. They bloom from June to October. Large bulbs, each, 15c; doz., \$1.50.
One of the most satisfactory and charming Spring flowering plants, producino in profusion its delicate bell-shaped, delightfully fragrant white flow ers. Lillies of the valley thrive in any common soil, are perfectly hardy, and will succeed in slady situation. Selected tips each, 5c; doz., 40c.

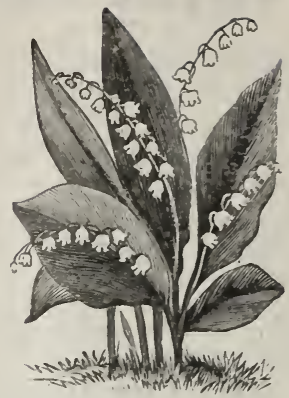

\section{Fall Bulbs}

We carry in season a selected stock of Fall Bulls, and as we do not issue a bulb catalogue, we list here the most popular and easy growing varieties.

\section{Hyacinths (Single)}

Dark Red, Yellow, Rosy Pink, Purple, Light Blue, White. Price, 6c each, (5ic per dozen

\section{Hyacinths (Double)}

Dark Red, Ytllow, Rosy, Pink, Purple, Light Blue. White. Price, 6c each; 65c per doz.

\section{Roman Hyacinths}

Blue, Pink. Price, 6c each; 75c per doz.

\section{Single Early Tulips}

Scarlet, White, Yellow, Purple, Pink, striped. Price, postpaid, 3c each; 30c per doz.

\section{Double Tulips}

Scarlet, White, Yellow, Rose, Purple. Price, postpaid, 4c each; 35c per doz.

\section{Parrot Tulips}

Crimson, Yellow, Yellow Bone-tipped. Price, postpaid, 3c each; 30c per doz.

\section{Narcissi}

Single, Double, Grandiflora. Price, $4 c$ each; $10 \mathrm{c}$ per doz.

\section{Freesias}

REFRACTA ALBA-Postpaid, 3c each; 30c per coz.

\section{Crocus}

Price, dozen, 15c; 100, \$1.00

\section{Jonquils}

Single, Postpaid, 3c each; 30c doz.

Double, postpaid, 4c each, 35c doz.

Iris

SPANISH-Each, 3c; doz., 30c.

\section{Snowdrops}

DOUBLE-Each, 3c; doz., 30c; 100, \$2.00.

\section{Oxalis}

Price, each, 4c; doz., 35c.

\section{Scillas}

SIBERICA-Each :ic; doz. 25c. 


\title{
SEED POTATOES
}

EARLY ROSE-This variety has been a great farorite for many years and many growers still claim that it has never been excelled in quality and productireness. Potatoes are long in shape, good size and light pink in color at the bud end. They cook mealy and are of the finest flavor. Price, postpaid, 3 lbs., 5oc; freight, $25 \mathrm{lbs} ., 75 c$; 100 lbs., \$2.00.

EARLY OHIO-A leading early sort, earlier than the Early Rose, but not so productire. Round short, and thick tubers, smooth and solid; cooks dry and mealy and ma. tures very early. Price, postpaid, 3 lbs., 50c; freight, 2.5 lts., 7.xc; 100 lbs., \$2.00.

WHITE OHIO-These are the same in all particulars as the Extra Early Ohio except in color, which is white or nearly so. White potatoes are preferred in most all markets and as this sort is just as early, of as good quality and as productive as the Early Ohio, it will unquestionably supersede the older variety when it becomes better known. Price, nostpaid, 3 lbs., 50c; freight, 25 lbs., \$1.01); 100 lbs., \$2.s0.

\begin{abstract}
NETTED GEM-The hardiest, most rigorous in growth, most productive, and the best in table cuality of all potatoes. It has prored to be unequaled for main erop. The vines are strong, with deep green foliage, making a healthy growth when other varieties are cut down by blight. In form the tubers are medium long. The eyes are small and there is very little waste in paring. The skin is thin and very smooth with the exception of rery small depressions which give it the appearance of being netted and from which it derives its name. Its color reminds one of a Golden Rus set apnle. The flesh is fine grained and cooks up mealy white. It is very free from scale and one of the very best keepers on the market. One grower tells us that they were in excellent condition in October, one year after being dng. These potatoes command the hiol. est prices in all markets where they have been introduced. Price, postpaid. 3 lbs.. (60c; fieight, 25 lis.,
\end{abstract} \$1.2.5: 100 lits., $\$ 3.00$.

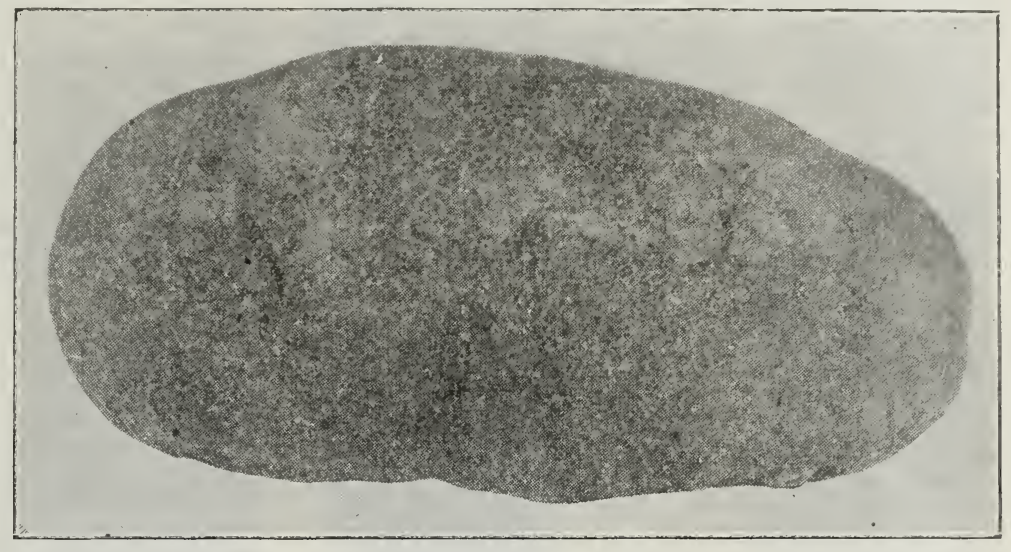

Netted Gem

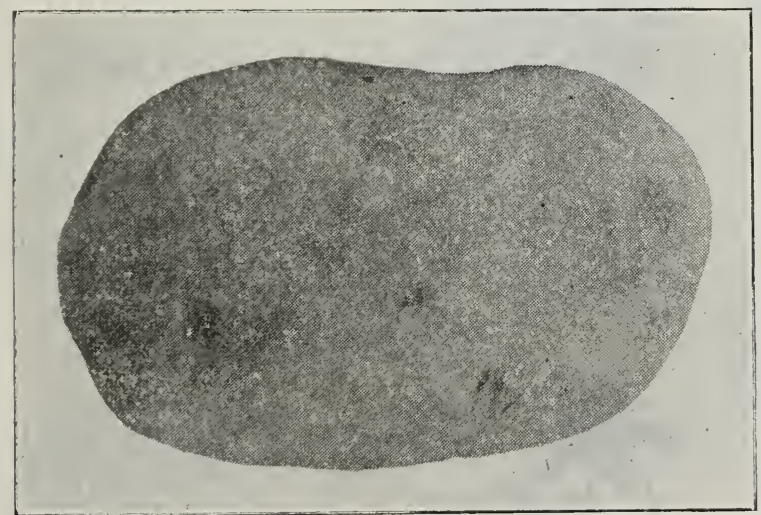

In order to increase the yield of Potatoes, use Clover Leaf Vegetable Fertilizer, see Page 37.

\section{MacGregor}

MACGREGOR-This new, late potato originated in Manitoba about six years ago and immediately became a general favorite. In appearance it closely resembles the old. well known Carmen No. 3 , same shape, with nice white netted skin, a grand good cooker at all times, a remarkable keeper and a tremendous yielder.

One of the most noticeable features of this potato is its wonderful vigor. It will send up a big strong vine and frequently give a good yield where other varieties would be a total failure. It has captured more first prizes at the Interstate Fair during the last three vears than any other potato. Price, posnaid, $3 \mathrm{lbs}$., 60c; freight, 25 lbs., \$1.2.; 100 lbs., \$3.00.

BURBANK (A Standard Late Variety)-Continues in good demand and is more largely used than any other. It is of good size, of fine form and an excellent yielder. The flesh is white, very mealy and of fine flavor and quality. The best potato for baking. This variety is went adapted to heavy soils. Price, postpaid, $3 \mathrm{lks}$., 50c; freight, 25 liss., 75c; 100 lks., \$2.00. 


\section{CLOVER and FIELD SEED}

\section{TAKE NOTICE}

Great care should be exercised in purchasing grass and clover seeds. This is even more important than witl other seeds, for on account of being perennials, and the land not being cultivated, it is difficult enongh at the best to keep weeds down, witlout sowing weed seeds. Also, they are the most easily adulterated witl cheaper seeds or dear seeds which will not germinate, and for that reason it is more economical to buy the very best seed obtainable at the highest price than ordinary seed at half the price. Cheap seed is expensive at any price.

That buying poor seed at a cheap price is not always econoiny is proved by experiments made by the Depart ment of Agriculture, reported in the Indiana Station rir cular No. 31. An analysis of high-grade red clover seed purchased by the government, showed that a bushel of the seed, that would grow, would cost $\$ 10.15$. The low grade seed purchased had so many impurities that $\$ 27.5:$ was spent in getting a bushel of good seed out of it. Sim ilar examination of alfalfa seed showed a cost of $\$ 13.1$. for the high-grade seed and $\$ 19.66$ for the low grade. High-grade timothy cost $\$ 2.62$ per bushel and the lowgrade $\$ 3.17$.

Owing to the extreme market changes we cannot print prices good for any length of time. When ready to buy write us for prices, stating quantity wanted, or if you send money, we will ship seed to cover amount sent.

\section{Alfalfa, or Lucerne Clover}

The most valuable forage plant; is particularly adapted for our Western climate and soil. It re quires a deep, mellow soil; newly broken sod does not do so well. It thrives best in a sandy loam. the richer the better, while it has not nroved a success on heavy compact clay soil. In the driest and most sultry weather, when every blade of grass withers. falfa is as fresh and green as in
the snring, as its roots go down from 10 to 20 feet to the moisture of the ground. Although a nrarligious rielder, it does not exhaust the snil. but rather improves the ground by the decay of its long ground. full of vegetable matter. The seed mav be grown early in the suring, as soon as the frost is

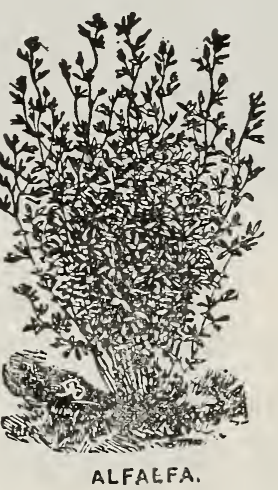
out of the ground, in order to catch the spring rains, as it needs moisture to germinate. In localities where irriga tion is used it can be sown successfully at any time during the suminer months. Most of our successful Alfalfa growers prefer sowing the seed broadcast, while others are more in favor of drilling it in. It is more difficult to establish the first year, but will, when once started pro duce a profitable crop; under favorable circumstances three and even four crops are cut yearly, aggregating five to seren tons to the acre. Never sow less than 15 pounds of good, clean seed to the acre, as thin sowing produces thick and coarse stalks not relished by stock. If intended to raise Alfalfa for the seed, 12 to 15 pounds is plenty to sow on an acre. It is worthy of trial in any locality where it has not already been tested. . Per lb., postpaid, 3.5c; 100 lbs., write for prices.

\section{Turkestan Alfalfa}

This new Alfalfa, introduced from Turkestan, has been experimented with more or less for the past few years. In some places it has proved a great suceess. In general appearance it is very much like our regular growth in the driest and hottest sections without irrigation. It is perfectly hardy and will stand extreme cold in winter withou harm. It yields a very heavy and rich crop of hay and makes permanent pasture. We have securea a good stock of the pure, genuine seed, which we offer at the following prices: Per lb., postpaid, 3sc: t100 lbs., write for prices.

\section{Dry Land Alfalfa}

For high, dry, hot land. We are now able to offer in quantity this new Dry Land Alfalfa, which will produce large, profitable crops of hay and excellent pasture on the hioh, dry lands of Eastern Oregon, Washinaton, Idaho and Utah. This is especially recommended for the hills and

plateaus which are above irrigation ditches or in sections where irrigation is impossible. The new "Dry Land" Alfalfa is what might be called "a new strain, acclimated to dry land.' Price per 1b., post paid, 35c; 100 lis. write for prices.

\section{Mammoth Red Clover}

Being a rank grower makes it most valuable for fertiliz. ing purposes. Foliage, flower and stem much darker than common Red Clover; ripens later than the latter, about the time Timothv Red Top and other grasses ripen, making thereby a much better quality of hay, when mixerl with them. Sow 12 to 15 lhs. to the acre. Per lb., postpaid, 40c; 100 lbs., write for prices.

\section{Alsike, or Swedish Clover (Trifolium Hybrium)}

A perfect hardy variety which is rapidy growing in popular favor. It vields large crops of excellent hay, and under favorable conditions may be cut several times during the season. It is also valuable for hees. It is well ralculated to resist $h^{+h}$ drough ${ }^{+}$and excessrve moisture The hay of this variety is greatly preferred by some to thit of Red Clover, for the reason that it is generally finer briohter and not so dusty, making it hetter fnr horses. It ic perennial and produces a mass of long fibrous roots which hold the snil. making it useful for nermanent nasture on hil. sides which are liable to wash. Wiren used alone sow from eight to ten pounds per acre. Per lb., postpaid, 40c; 100 lbs., write for prices.

\section{White Dutch Clover (Trifolium Reptns)}

A small variety having a white blossom. It is of a vining. nature, spreading rapidly and will soon cover bare spots if the stand be even. It does not attain sufficient height to be profitable for hav. but is superior for pasture, either for cattle or sheep, and unsurpassed for the production of honey. It also makes a beautiful lawn when mixed with Blue Grass. If sown alone, use six to eight pounds per acre. Fancy for lawn. Per lb., postpaid, 60c; 109 Ibs., write for prices.

\section{Medium Red Clover}

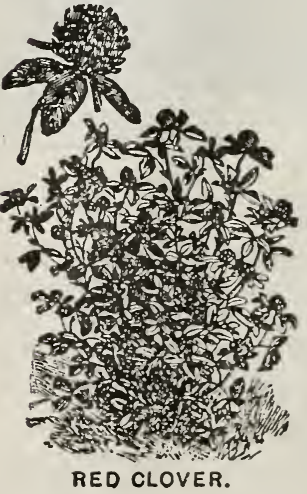

For Books on Farming, see Page 74.
The standard clover for all purposes, either hay, pasture or for improving and enriching the soil. It is hardy and succeeas well on any good soil. It yields the lesriest crop of any elover except alfalfa, a n il makes superior hay-especially if mixed with timothy-either for dairy rows or for general use. Sow from twelve to fif. te $n$ pounds ner acre, being careful to get it evenly distributed over the ground. Per lm. postpaid. $402 ; 100$ lbs., write for p:ices. 
CLOVER \& FIELD SEED-Continued

\section{Bokhara, Sweet or Honey Clover (Melilotus Alba)}

A rapid growing, white flowered sort; excellent for bees Sow ten pounds per acre. Per lb., postpaid. 35c

\section{Crimson, or Scarlet Clover (Trifolium Incarnatum)}

Highly recommended for pasture and iertilizing pur poses. It is a thrifty annual, growing from twenty to thirty inches high, and has a heautiful crimson bloom. It germinates quickly, grows rapidly and stools abundantly. Sow from twelve to fifteen pounds to the acre, and harrow it with a light harrow. Cut for hay when in full bloom. Per lb., postpaid, 30c; 100 lbs., write for prices.

\section{Esperette, or Sainfoin (Onobrychis Sative)}

A deep rooting, perennial legume, extensively cultivated on dry, calcerous soils which are too barren for clover or alfalfa. It is rather difficult to establish, as plants are easily killed when young, but when once rooted, will live from ten to twenty-five years. Sow 50 pounds per acre. Per lb., postpaid, 30c; 100 lbs., write for prices.

\section{Timothy Seed}

Timothy is a native of Europe, but long ago naturalized in Amer ica, where it ranks as by far the most important of hay grasses. Its popular name, by which it is now known the world over, refers to Timothy Hanson, who did most to make it known and appreciated. On moist, loamy or clayey soil it produces a larger hay crop than any other grass It is not so well suited for light, sandy soils. Though preferring a moist, temperate climate it withstands drought and extreme heat and cold. Its hay is very nourishing and can be preserved for a long time. It should he cut when flowering. as, if left later, the hay becomes hard and coarse. It is often sown along with red clover, and the nutritise value of the hay is greatly increased br the mixture. Height. 2 to 3 feet. Per lb., post paid, 20c; 100 lbs., write for prices.

\section{Italian Rye (Lolium Italicum)}

This is distinct from the preceding, being of much larger and stronger growth, with large, broad, glossy green blades. It succeeds best in moist, fertile soils. About twenty pounds to the bushel; three bushels to the acre. Per lb., postpaid, 25c; 100 lbs., write for prices.

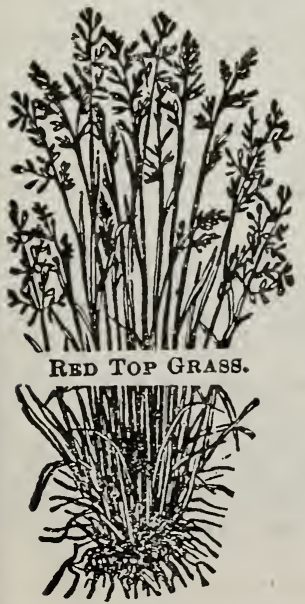

\section{(Agrostis Vulgaris)}

RED TOP (Agrostis Vulgaris)-In Pennsylvania and states further south, this is known as Herd's Grass, a name applied in New England and New York to Timothy. 1t is a good, perennial grass, standing our climate well and makes good pastures when fno close. Is valuable for low, wet meadows, producing a large return in good hav, When sown alone. use twenty-eight pounas of the chaff seed per acre. Sow in spring or fall. F a n c y (cleaned from chaff). Sow 8 to 10 pounds per acre. Per lb.. postpaid, 30c; 100 Ibs., write for prices.
Tall Meadow Oat Grass (Avena Elatio)

$A$ hardy perennial much used in the south and west. Its roots penetrate deep, and it thrives on any good soil. It yields a heavy crop and is valuable for both meadow and pasture. If used alone, sow from thirty to forty pounds per acre. Per lb., postpaid, 35c; 100 lbs., write for prices.

\section{Brome Grass (Bromus Inermis)}

A perennial grass valuable for binding the soil of em bankments and on account of its ability to resist both drought and cold. On light, dry soils it is used for both hay and pasturage, but it is not recommended for locations where better grasses will succeed. Should be used at the rate of twenty pounds per acre. Per lb., postpaid, 30c: 100 lbs., write for prices.

\section{English Rye Grass (Lolium Percune)}

This makes a quick growth very early in the spring, and is adapted for cool, moist locations, recommended for fall seeding on Bermuda-grass lawns in the south, giving them a bright green appearance all winter. Twenty-four pounds to the bushel; three bushels to the acre. Per lb., postpaid, 25c: 100 lbs., write for prices.

\section{Orchard Grass}

No farmer should be without a small field of Orchard Grass, as in many respects it is superior to all other grasses. It stands the drouth, grows well in the shade, does well in wet or poor ground, and is splendid to prevent worn-out fields from washing. This grass furnishes excellent pasturage three weeks before any other, and after close grazing ten days' rest is sufficient for another growth. Cows fed on this will produce more and richer milk than on blue grass. It makes a very heavy sod and when well set remains for many years. It is especially adapted for winter grazing, as it remains green all season. Per lb., postpaid, 35c; 100 lbs., write for prices.
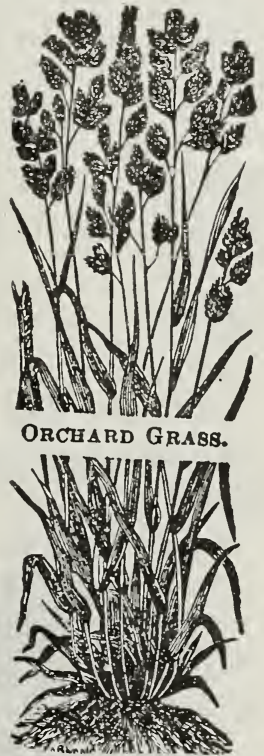

\section{Kentucky Blue Grass}

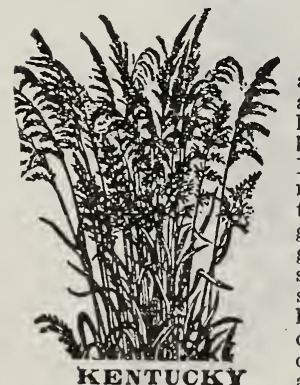

This makes the best, sweetest and most nutritious pasturage for all kinds of stock. Kentucky has long been famous for its high-bred horses and its blue-grass pastures. It is now possible to establish on most any farm a biue-grass pas. ture of greenest verdure which wil give very profitable returns. This grass is the first to start up in the spring and remains green unts snow flies in the fall. It is very hardy and is uninjured by cold or dry weather, hot sun or tramping of hoofs. The roots are so thick and stout as to form a tough sod. BLUE GRASS.

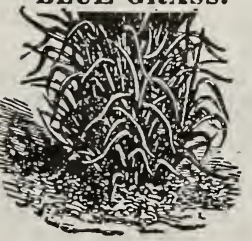
Blue grass requires about two years to get well started and for that reason it is often sown in $\mathrm{mlx}$ ture with other grasses. It will dn well on almost any land. Sometimes called "June Grass." From 20 to 25 pounds of "Sterlina" rrade seed reauired to the acre. Per lb., postpaid, 35c; 100 lbs., write for prices.

For Books on Farming, see Page 74. 
Meadow Fescue (Festuca Pratensis)

A perennial variety growing three to four feet high. It roots deep, but resisting drought better than most grasses. It succeeds on any ordinary soil; yields a heavy crop of superior hay; one of the best grasses for pasturage. Valuable to mix with other kinds. Use 20 pounds per acre for prices.

\section{Canadian Blue Grass (Pea Compressa)}

A hardy perennial growing on poorest and driest soils. Short ( 6 to 8 inches), hard and wiry, but high in nutritive value. Decidedly blue in color. Stems flattened. Invaluable for use on steep places or exposed situations. Sow three bushels to acre. Per lb., postpaid, 30c; 100 lbs., write for prices.

\section{How to Make a Lawn}

The ground should be spaded deeply and thoroughly, and a good compost of decomposed and finely pulverized manure or rich loam spread over the ground. It would be well, also, to give a sprinkling $\mathrm{f}$ bone dust. Then use slanted tooth harrow and a light or medium roller until the soil is smooth, even and firm. Then sow the seed and harrow again and smooth off with a common garden rake. When the grass has grown 2 or 3 inches in height use the lawn mower, gauged to cut full one inch above the ground; repeat the same as often as it grows to that height. 'I'he weeds and foul grass can be kept down and destroyed by the repented mowing. If this is neglected they will spread and take possession of the soil, but being constantly clipped, the leaf and seed stalks are destroyed and the foul vegetation disappears.

As a guide for the proper quantity to order, we may state that one pound of Fancy Mixed Lawn Grass Seed is sufficient to thoroughly sow an area of 20 feet by 15 feet300 square feet. It should be borne in mind that in order to produce the best results grass seed for lawns should be sown at least thrice as thicklr as if sown for hay.

As soon as the grass has become well established a dressing of good Lawn Fertilizer is necessary to keep up that beautiful fresh appearance.

\section{LAWN GRASS}

\section{Our Own Mixture}

This is especially fine. Carefully prepared. Will give best results. Per lb., postpaid, 45c; by express, $10 \mathrm{lbs}$., $\$ 3.00$.

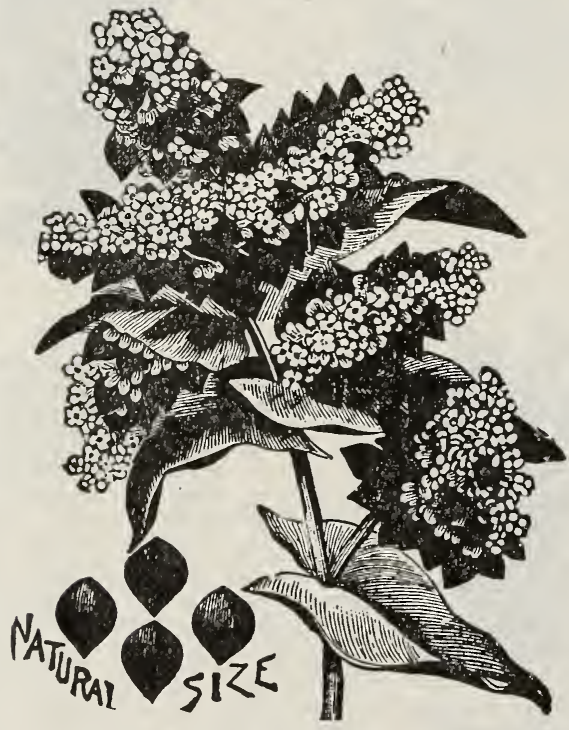

\section{Buckwheat}

JAPANESE-This variety excels all others; yield much heavier; ripens one week to ten days earlier; stands up better and makes better flour. Excellent for bee pasture. $\operatorname{Pr}$ lb., postpaid, 20c; 100 lbs., write for prices.

SILVER HULI-A very good and popular variety. Grain is of light gray color, rounder than the common; has a thin husk; matures earlier and yields heavy. A good milling variety. Per lb., postpaid, $20 \mathrm{c} ; 100 \mathrm{lbs}$., write for prices.

\section{MILLETS}

GERMAN MILLET-No other grass or forage plant has been able to produce the enormous yield of this plant. It has produced four to five tons of hay to the acre, ana from 70 to 80 bushels of seed. It is sown in the spring on newly broken prairie, and after harvesting it leaves the ground in the finest condition for wheat. Sowe 25 to 40 pounds to the acre. Per lb., postpaid, 20c; 100 lbs., write for prices.

MANITOBA O R HOG MILLT
Very rich and thus especially valuable as a hog food. A very much prized peculiar ity of this millet is that the seed ripens while the stem is yet green, thus if cut promptly c a n be threshed for the seed, while the hav after being threshed will make excellent fodder. Sow same as other millet. Per lb. postpaid, 20c; 104 lbs., write for prices.

NEW SIBERIAN, OR RUSSIAN TNTL IET-Is claimed to be the most wonder fully productive and satisfactory for age plant, possessins in a superior degree all the essential merits of any of the older sorts - exceed ing them by far-be sides many other points of excellence that distinguish it and render it a most valuable addition to the list of forages, and, if the claims are well founded destine it to take front rank and if not lead all the rest. The claims made by its introducers are that it is from two to three weeks earlier than the German Millet. is a much heavier cropper, that the hay is much finer, stalks more elastic and growing much taller, that it is rust-proof, and chinch bugs do not relish it, and be ing of stooling habit. requires much less seed per acre. You should try it. Per lb., postpaid, 20c; 100 lbs., write for prices.

HUNGARIAN MILLET-This grass resembles millet very much. It is of fine growth, and makes an excellent hay. It has numerous succulent leaves, which furnish an abundance of green fodder, taken by all kinds of stock. Sow 25 to 30 pounds to the acre. Per lb., postpaid, 20c 100 lbs., write for prices.

JAPANESE MILLET-Is of recent introduction, and great claims are made for it as to productiveness and value as a forage plant. Its introducers say that it is a marvelous grower and luxuriant stooler. Recommended highly for feeding dairy cattle, young stock and sheep, being very rich in nutritious elements. Grows from four to seven feet tall, but is not harsh and woody, as other grasses are. In some sections of the country it is known as Barnyard Millet, while in other parts of the country it has been erroneously introduced under the name of Billion Dollar Grass by some seed houses. In spite of these names it is such a good thing that it has come to stay, and will live long in the public favor under its proper name, Japanese Millet. Per lb., postpaid, 20c; 100 lbs., write for prices. 


\section{Dwarf Essex Rape}

Main standby of the English farmer in raising choice mutton. Perfectly hardy, and of remarkable fattening properties. Easily grown. One acre will pasture 36 head two months, and lambs will make a gain of from $\&$ to 12 pounds per month. Pigs and cattle are also extremely fond of it. A rery rank grower and bears heary manuring and high cultivation. Sow at intervals of several weeks and secure a supply of good feed. Sow in June. Rape should

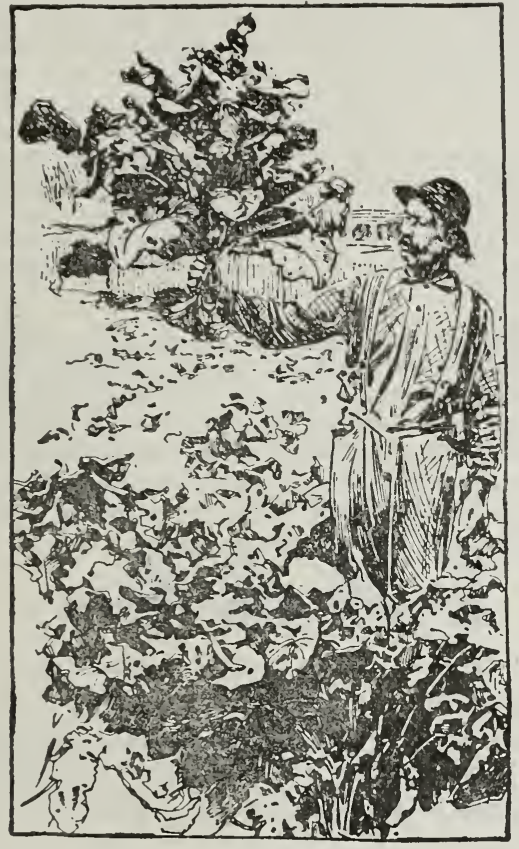

be fed in lugust, though if a first crop be cut about four inches from the ground an after-growth would be useful later. For breeding flocks a piece should be sown first week in July or later. Does well sown with oats. If soil is rich and clean sow broadcast, otherwise in drills and cultivate same as corn. Poultrymen will do well to grow a small patch to feed rreen to growing chicks. Can be sown on wheat stubble, furnishing excellent pasture late in the fall. Broadcasted it takes 8 to 19 pounds to the acre. Lb., 2ic postpaid. express or freight; $10 \mathrm{lbs}$., $\$ 1.00 ; 100$ lbs., write for prices.

\section{THOUSAND HEADED KALE}

The great demand for this wonderful forage plant proves it to be the most valuable green feed for Pacific Coast dairy and stockmen: endorsed by Agricultural Colleges and Government Stations. Postpaid, oz., 10c; 1/4 1b., zטc; 1b., 60c.

\section{Fgyptian Corn}

\section{Also Called Jerusalem Corn or Dhoura}

One of the non-saccharine sorghums, requiring the same growing conditions. Succeeds well in dry sections. Producing small heads on side shoots up to eight on a stalk, the seed is larger than Kaffir corn. Yield is heavy. Makes fine chicken feed. Plant three pounds per acre. White, per 1b., postpaid, 20c.

\section{Kaffir Corn}

An excellent fodder plant, yielding a large crop of fodder during a season. Grows four to five feet high. uprioht stalk, with numerous large leaves. Greatly relished by cattle and horses. The seed crop is also heavy, sometimes vielding 60 bushels to the acre. It does best sown in drills three feet apart, using six to eight pounds of seed per acre. Per 1b., postpaid, 20c; 10 lbs., 60c; 100 îbs., $\$ 4.00$.

\section{Broom Corn, Improved Evergreen}

This is the most popular variety of broom corn to orow for the market. the brush being firm and of good length, and retaining the light green coloring when nroperly cured Per lb., postpaid, 20c.
This is one of the sorghums similar to Kaffir corn. Grows erect, with thick, close-jointed stalk. Height, 4 to 7 feet. Heads are very large, giving a heary graint, is drouth resistant, and succeeds on alkali soil. Plant inte when ground is warm, 3 to 6 pounds per acre. Price, per lb., postpaid, 20c.

\section{Sugar Cane, Early Amber}

The high value of northern grown sugar cane for fodder and ensilage is becoming rapidly known. It may be made to furnish the princival food for cattle and horses from August until the following spring. When fed down young as a pasture it grows rapidly again. It also withstands severe drouth with the best of this kind of plants. As a fodder and for winter feed it is one of the most economical. The Early Amber is the best variety for sugar, and it matures quickly. Per lb., $\$ 6.00$.

\section{Sunflower, Mammoth Russian}

The largest and most productive variety. Heads often 12 to 20 inches across. Every farmer should plant a few rows at least. It makes one of the very best of food

\section{Canada Field Peas}

CANADA FIEID PEAS-This pea is adapted to cultivation in Washington, Oregon and British Columbia. This should be sown in the early soring, at the same time as grain, using from one to one and a half bushels of peas and an equal quantity of either wheat or oats or barley. The crop is ready to cut for hay when the dominant variety in the mixture is nearly ripe. If there are more peas than grain, then the yellowing of the peas and poas marks the time for cutting, or if the grain exceeds the peas, then the crop should be cut when the grain is
the dough stage. Per lb., postpaid, 200; 100 1r.s., 34.01 .

\section{Vetches}

SPRING - A pealike plant grown extensively in England and to a considerable extent in Canada, for stock feeding, but not as much used in the United States as it should be. Culture same as field grown and cowpeas. Per 10., $\mathbf{2 0 c}$ postpaid; 100 libs., write for prices.

WINTER, SA N D OR HAIRY VETCH (Vicia Villosa) This is a very valuable iorage piantand isecoming more popular every year. It belongs to the pea family. but tho vin es much longer and the foliage riore abundant - it im. proves the soil, being a great nitrogen gatherer. It is an annual. but droos its seeds freely and come ur year after year on the same around. $T h$ e $n$ can be plowed under same as cow peasit is advisable to Haw ow Vetches
rye, etc., with Vetch which serves as a support for the plants. It succeeds on almost any soil and should not winter kill. A sowing in August or September covers the ground before winter and prevents washing during the winter and early spring. Can also be sown in Aprii and will be ready to eut by the middle of July the second growth affording excellent hog pasture during the summer. The vield of forage varies from ten to fifteen ions per acre equal to three or four tons when cured as dry hay. Would suggest sowing about 30 pounds to acre. Per lb., postpaid, 30c; $100 \mathrm{lbs}$., write for prices.

For Broadcast Seeders, see Page 43 
Barley

BEARDLESS BARLEY-Very early and free from beards; handles as easily as Oats, making a stronger feed. Makes magnificent hay for work horses. Sow as early as you can; frost will not hurt it. $100 \mathrm{lbs} ., \$ \mathbf{2 . 2 5}$.

WINTER BARLEY-This is a bearded variety that was introduced in this vicinity two or three years ago. We are slow to offer new varieties, but this has proven su valuable an addition to our grains that in some sections all other varieties are being discarded. We have made arrangements for and expect to be able to supply this in any quantity for fall seeding. Price, $100 \mathrm{lbs}$., \$2.50.

\section{Speltz or Emmer}

SPELTZ OR EMMER-The valuable new grain from Russia. It is readily eaten by all kinds of stock, and has shown itself to be especially adapted when fed to milch cows. It is better to mix it, however, with bran anu shorts, as it is a pretty heavy feed when fed alone. As a swine feed, we think very well of it, indeed, especially for breed sows. Horses do well on it, but I do not think it is equal to oats in that case. Its most striking value is found in the fact of its drouth-resisting qualities. The United States Department of Agriculture has issued a bulletin on Speltz, commending it highly, and the introductory paragraph of that bulletin states:

"The extremely variable climatic conditions in some of our western states have made it desirable to give particular attention to crops resistant especially to cold and drouth. Among such crops Emmer holds high rank and should be come one of the prominent crops for stock feeding.

Price, 100 lbs., \$3.00.

\section{Flax Seed}

RECLEANED FOR PLANTING-Per 1b., postpaid, 20c; 100 lbs., write for prices.

GROUND FLAX-For medicinal uses. Per lb., 15c; 100 lbs., write for prices.

OII MEAL-For feed purposes. 120-1b, sks., \$3.60 per sk. Special prices in quantity.

\section{Kill the Smut in Your Grain}

If there is smut in your wheat seed destroy the smut and persist in it; you should also insist that your neighboring wheat growers endeavor to destroy the smut. This trouble is becoming very prevalent. Smut must be stroyed if wheat is to keep up its high grade of milning qualities.

\section{Remedies for Smut}

BLUESTONE-Market price. Use $1 \mathrm{lb}$. to $5 \mathrm{bu}$. grain. FORMALDEHYDE-One-lb. bottle, 40c. Use $1 \mathrm{lb}$. for 40 to 50 gallons of water.

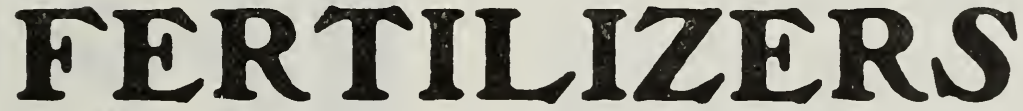

Most soils in the State of Washington are yet fairly new. Their native or virgin fertility is not yet exhausted. There are, however, many different types of soils in the state, some of which do not naturallv contain very large supplies of the different elements of plant food needed by crops. Such soils are likely soon to "run out" and need application of fertilizers carrying the particular elements in which they are deficient. Other soils which carry fairly good supplies of different elements of plant food have been improperly handled or wastefully cropped until badly out of condition. These can best be restored to or built up in fertility by the use of fertilizers to stimulate increased growth until the soils can be properly brought back into good condition. Fertilizers mav. therefore. be used for two separate purposes: namely, the application of some one or more single elements of fertility to crrect deficiencies in those particular elements or the application of a complete mixed fertilizer to stimulate crop growth.

The only possible means of determining whether fertilizers for either of these purposes can be profitably used is by field experiments. A chemical analysis of the soil indicates the total amounts of plant food which are present but does not show how much of this is available for use of different crops, nor does it prove whether the use of any given fertilizer would yield enough increase in crop growth to pay for the cost of the fertilizer. Field trials with fertilizers are, therefore, the only conclusive evidence of their value.

\section{Complete Fertilizers}

Complete Fertilizers are those containing correct proportions of all of the essential plant foods, viz.: Nitrogen, Phosphoric Acid and Potash. Different crops require different proportions of these plant foods, and for convenience and best results to our customers we mix fertilizers, individually, but unless the farmer has made a study of the subject, experimented, and knows exactly what his snil requires, better results will be obtained by using the com. plete mixed fertilizers.

\section{$1 \quad$ Clover Leaf Vegetable Fertilizer}

\section{A Complete Fertilizer for All Garden Crops}

For general use whehe any one thing is not planted ex tensively, we prepare this formula containing an average percentage of each of the three plant food elements which combine to make all vegetation, to give the best results on the great majority of crops in all varieties of soils. Consequently it is the most satisfactory and economical fertilizer for the truck gardener and for the home vegetable garden.

At the rate of 600 to $800 \mathrm{Ibs}$. to the acre would be a fair dressing, and would be equal in fertilizing value to about eight tons of ordinary stable manure. It is free from the millions of weed seeds invariably found in stable manure.

Like other Complete Fertilizers, it may be sown broadcast on the plowed ground, and harrowed in, before planting; or it may be drilled in close to the rows of seeds or plants after seeding or during the early growing season. Price, 100 lbs., \$2.25; ton, $\$ 40.00$.

\section{Chemical Fertilizers}

Chemical Fertilizers contain only the one chemical, and are consequently not complete fertilizers. They produce wonderful results when properly used, but you should experiment and study the matter carefully before investing in large quantities. Many persons know only of Superphosphate as a commercial fertilizer, and apply it promiscuously on any soil or crop, and, if it does not produce the desired results, condemn commercial fertilizers in general.

Most soils contain sufficient quantities of one or two of the three ingredients necessary for fertility. in which case, if by experimenting, you have ascertained what is lacking. it is only necessary to add that which is lacking. It is often advisable to use stable manure, or to plow under a green manure crop, and then apply chemical fertilizers to balance the chemicals which the manure contains in insuf ficient quantities.

\section{Super-Phosphate}

This is what is known as Acid Phosphate, being Phosphate rock treated with acid to make the Phosphoric Acid available. While the Phosphoric Acid in this is not so valuable as that in Bone Meal, it is more quickly available, and for that reason is sometimes more useful. It contains 20 per cent Phosphoric Acid, and is generally used at the rate of $500 \mathrm{lbs}$. to $1,000 \mathrm{lbs}$, per acre. Price per lb., 5c; 100 lbs., \$1.65; ton, $\$ 29.00$.

\section{For Book on Fertilizing and Fertility of Soils, see Page 74.}


Contains 13 per cent Nitrate, in quickly arailable form. Nitrate of Soda is principally used for a top dressing and should not be used in general fertilizing as it is too free. After an application of Nitrate of Soda results will be seen within twenty-four hours and all the benefits will be had from the fertilizer within two or three weeks. It is used for forcing crops like lettuce, celery, etc., as it mises a large growth of leaves and tops.

Apply the Nitrate of Soda by broadcasting it evenly over the entire surface of the vegetable field you are fertilizing, at the rate of 200 pounds per acre, before seeding, or planting, or transplanting.

As Nitrate is a powerful plant tonic and energizer-it is not a stimulant in any sense of the word-a very small quantity does a rery large amount of work. The quantity to be used per acre, althougl small, will be adequate to make a very striking increase in the amount of vegetables produced. A tablespoonful of Nitrate of Soda in three gallons of water, soaked in the ground around the roots once a week, will keep destructive bugs from growing vegetables. Price, per 100 lbs., \$3.75; 1,000 lbs., \$3.5.00.

\section{Muriate of Potash}

Put up in 22.)-pound bags. Contains 50 per cent Potash. The fertilizer is especially valuable in Western Washington and the Willamette Valley, as Potash is a plant food that is deficient. Use about one sack to the acre. Price, per $100 \mathrm{lbs}$., \$3.75; 22.5-lb. bags, \$7.50.

\section{Sulphate of Potash}

Put up in 22.5-pound bags. Contains 50 per cent Avail able Potash. This is similar to Muriate of Potash brit is free from chlorides, and can be used to advantage in some instances where the muriate can not be used. Advise all customers to send to us for a book on Potash Salts. Tells the difference between the various kinds and where each one is most arailable. Use about one sack to the acre. Price, per 100 ibs., \$4.00; 2.25-1. bags, \$5.25.

\section{Kainit}

Is a crude salt; that is, it has not been refined or manufactured, other than being ground into a condition ready for application as a fertilizer. It is sold under a guarantee of 12.4 actual Potash and contains Potash binth in the forms of Sulphate and Nuriate. It contains Salts $n f$ Magnesia and also common Salt. Kainit can be used upon the crops for which Muriate of Potash is recommended. Price, per 100 lbs., $\$ 2.00 ; 225$-1b. bags, $\$ 3.50$.

\section{Land Plaster, or Gypsum}

Made from pure Gypsum, absolutely free from clay or other foreion matter. This is especially raluable for clover and grass crops. Per 100 lks., \$1.00.

\section{ANIIMAL FERTILIZERS}

Animal Fertilizers, being made from animal matter, add warmth and life to the soil. Most of them contain both Nitrogen and Phosphoric Acid, but do not contain Potash, so that to make them complete, it is necessary to add the correct proportion of chemical fertilizers.

\section{Bone Meal}

This contains 3 per cent Nitrogen and 22 per cent Phosphoric Acid. Bone Meal is the basis of almost all fertilizers and is probably the cheapest and most valuable fertilizer that we have. It is slower in action, but will not dissolve and waste in the soil, as the plant food contained in the Bone Meal is released only as fast as tue roots of the plants take it up. Our Bone Mreal is all made from the fresh bone, which contains all of the Phosphate. Price, per 100 lbs., \$2.50; ton, $\$ 45.00$.

\section{TANKAGE}

This is a slaughter-house product composed of mant scraps, hoofs, tendon, bne, etc. These are ground into a fine meal, having but little odor and serves as a usefnl earrier of both Nitrogen and Phosphoric Acid. The analy. sis shows 5 to 7 per cent Nitrogen and 12 to 15 per cent Phosphoric Acid. Per 100 lbs., \$1.50; ton. \$25.00.
Pure blood, cooked, dried and finely ground. A quickacting fertilizer analyzing very high in effective Nitrogen; in fact, the Nitrogen of Dried Blood is one of the most effective forms of organic Nitrogen known. This also car ries sme Phosphorous: is a strong fertilizer. a little going a long way. Per 100 lbs., \$3.00; ton, \$45.00.

\section{Wilgrow}

The perfect concentrated fish fertilizer for the house garden, flower garden, fruit orchard, vegetable field. lawn, nursery, hothouse and potted plants. Weight $1 \frac{1}{2} \mathrm{lbs}$. Price, 2ac.

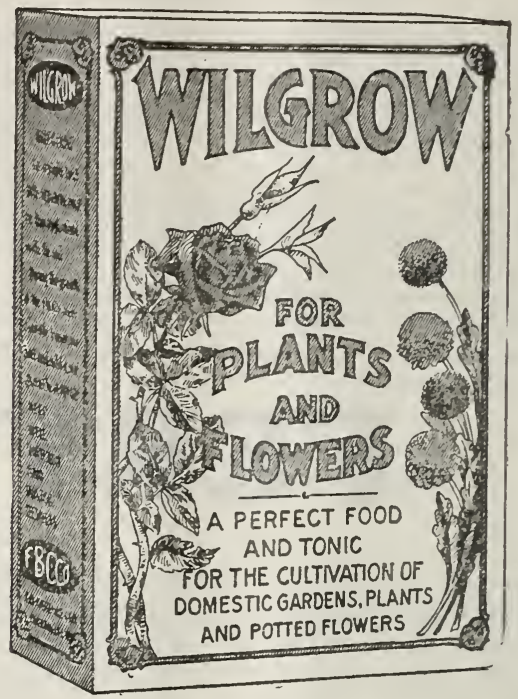

For a combined Hill and Drill Seeder anci Fertilizer, see Page 40.

For Book on Fertilizers, see Page 74. 
Farm and Garden Tools

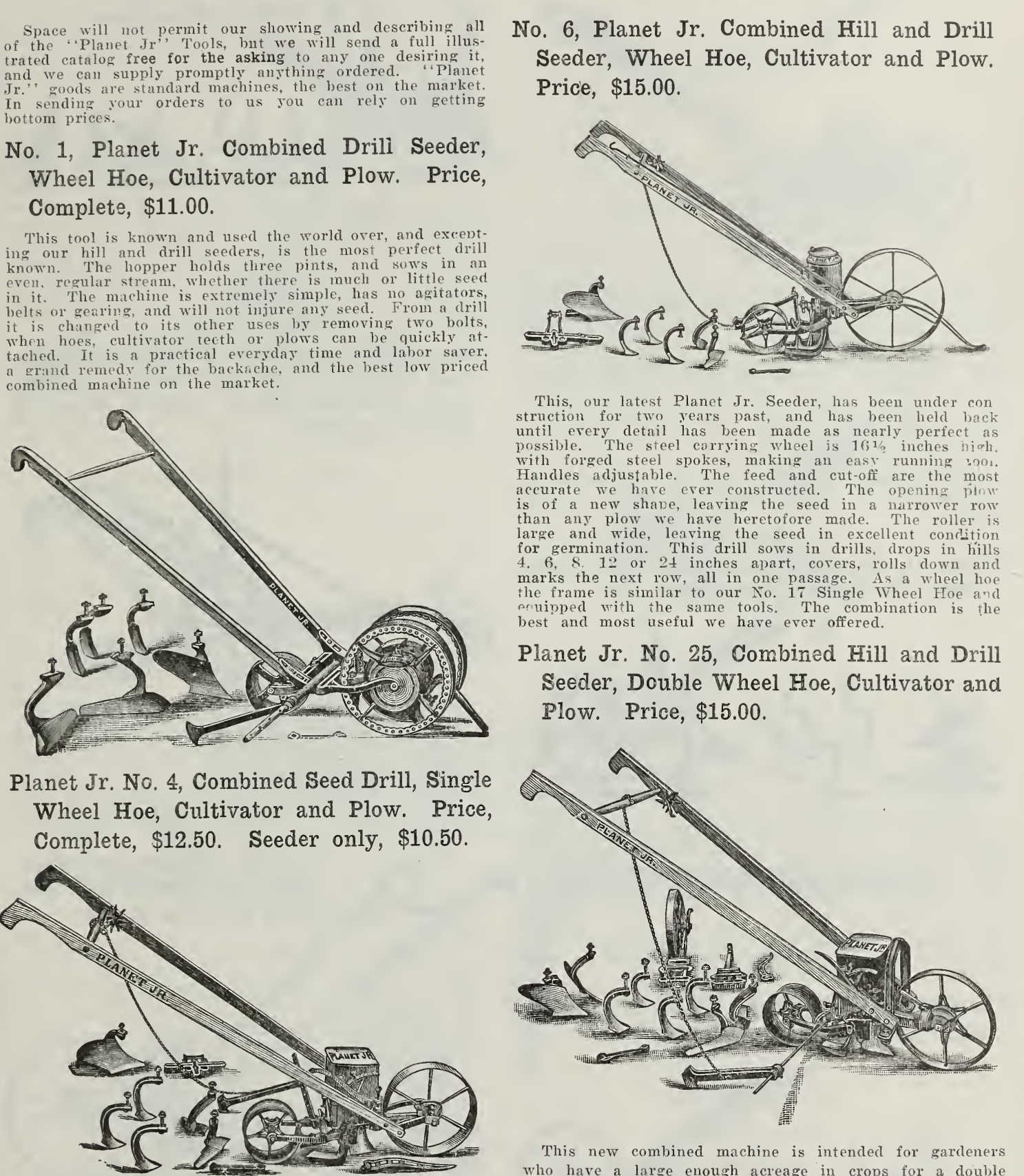


No. 21, Combined Hill and Drill Seeder and Fertilizer. Price, $\$ 22.00$.

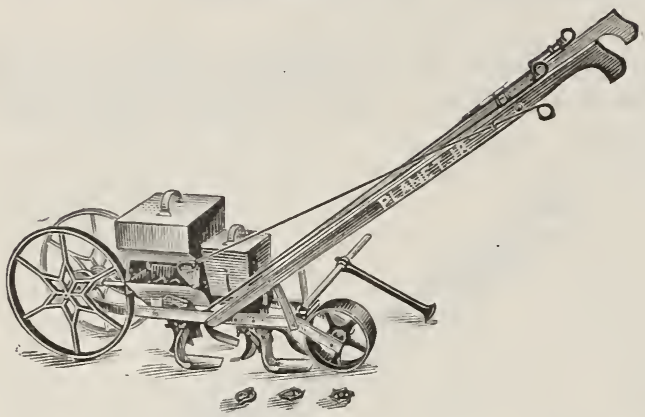

No. 21 has been much improved for 1913 and meets the demand for a drill to sow seed and fertilizers at the same time. This tool may be used to sow seed only, in either hills or drills, as desired; or to sow fertilizer only; or to sow both together. Its work is equally perfect when used in any of these ways. It sows all garden seeds in hills, $4,6,8,12$ or 24 inches apart, or in drills, and also fertilizer, placing it above or below the seed as desired. The quantity is reoulated by our patent feed rod and index at the ton of the handle. The seed hopper holds 2 quarts; the fertilizer hopper 4 quarts.

No. 21 is gradually growing in popularity and the demand indicates satisfaction given.

While performing a double service, it does not run too hard for the work accomplished. The parts are galvanized and the whole get-up is a desirable one. Packed weioht, 94 lbs.

Planet Jr. No. 12, Double Wheel Hoe, Cultivator and Plow. Price, $\$ 8.00$.

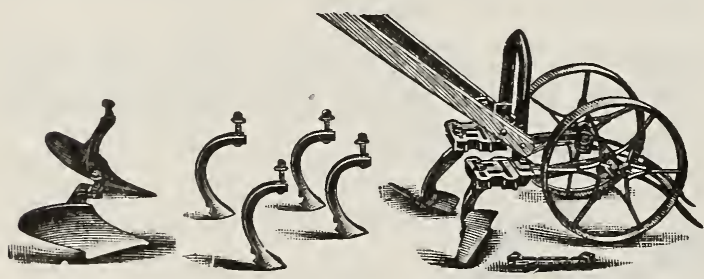

Two acres a day can be easily worked with this implement, and when it is done it will be a better job than three men could have done with hand hoes. The No. 12 runs either astride or between the rows; kills all the weeds and leaves the earth in fine shape. Then, too, it's so easy to work. Twelve-year-old girls work gardens with them with ease and success.

The No, 12 has a pair of 6 -inch hoes, a pair of plows for opening or covering, and a set of four all-steel rilti. vator teeth. The tools shown are what gardeners use most and others can be added as wanted.

Planet Jr. No. 17, Single Wheel Hoe, Cultivator and Plow. Price, $\$ 6.00$.

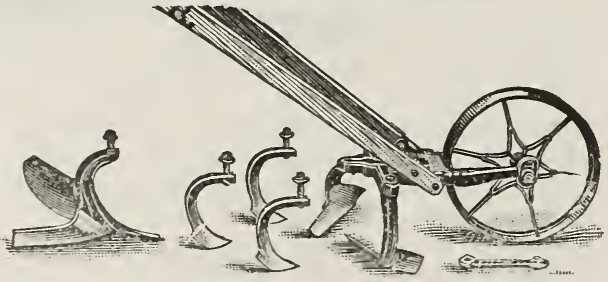

For easy gardening and at the same time clean and perfect gardening, the kind that will make your garden the talk of the neighborhood. and cause your face to glow with honest pride, nothing is quite the equal of this Nn. -1 Theel Hoe. It is suited to all kinds of garden cisltivation and all garden crops. You can do more and hetter hoeing with it in one day than you can do in three days with a hand hreo. The No. 17 has a pair of finch hoes, a plow and a set of cultivator teeth, an outfit sufficient or most garden work.

Other attachments can be added at any time.

\section{No. 11, Double Wheel Hoe}

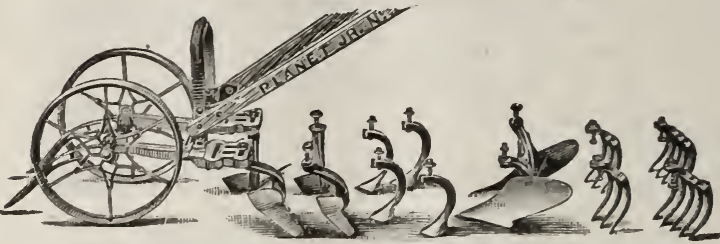

This is the greatest cultivating tool in the world for the onion and the sugar beet grower, and also for every grower of garden crops from drilled seed. They can do mole work and do it better and easier than can possibly be done in any other day. One pair 6 -inch hoes, one pair fi-nch hoes, two pairs hollow steel cultivator teeth, one pair plows, two 3 -tooth rakes, two 5 -tooth rakes, and two leaf lifters. Packed weight, 37 lbs. Price, with attachments as in cut, \$10.25.

Planet Jr. Twelve-Tooth Harrow, Cultivator and Pulverizer. Price, Complete, $\$ 11.00$; with Pulverizer, $\$ 9.10$; without Wheel or Pulverizer, $\$ 7.80$.

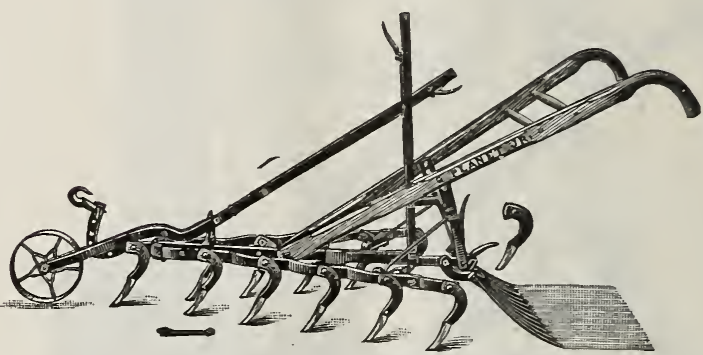

Gardeners cultivate better than formerly. It has been found to pay best. The farmer or gardener is most likely to cultivate best who has the tool best adapted to his purposes. With the 12-tooth harrow here shown you go as deep or shallow as you like, come up close to row without injuring plants, cut out all the weeds, stir the soil and mellow and fine it as with a garden rake. You widen and narrow as you please between 12 and 32 inches. It's a special favorite with strawberry growers, market gardeners and truckers.

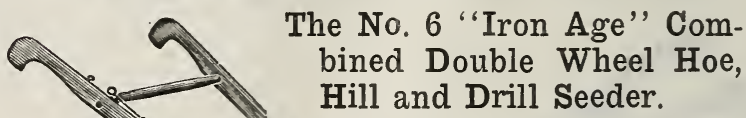

The No. 6 "Iron Age" ComHill and Drill Seeder.

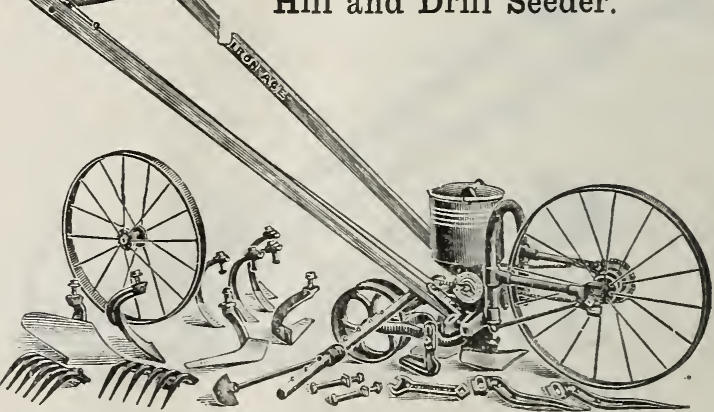

This tool is without question the most practical and complete combined garden tool ever offered the publicthe ease and simplicity of adjustment, the lightness combined with great strength, the accuracy by which it drills or hills the seed, and the small amount of power required to operate it, are the important features. The wheel is made of steel, 16 inches high, the frame of pipe, coupled to malleable castings. In each form, whether a seed drill, a double wheel hoe, or a single wheel hoe, it is equal to any tool or tools made especially for the one purpose. It places the seed in drills or in hills as at $4,6,8,12$ or 24 inches apart. Complete as in cut. Price, \$12.50. 
Onion Set Harvester. Price, \$1.25. Weight, $1 \frac{1}{2} \mathrm{lbs}$.

A useful attachment for our combined drills and all our wheel hoes. Eight-inch size for onions and onion sets. It leaves the crop in the best condition for easy handling.

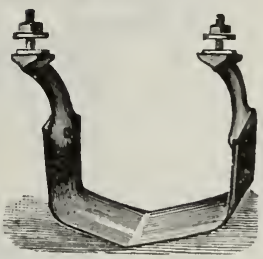

No. 6 Horse Hoe and Cultivator

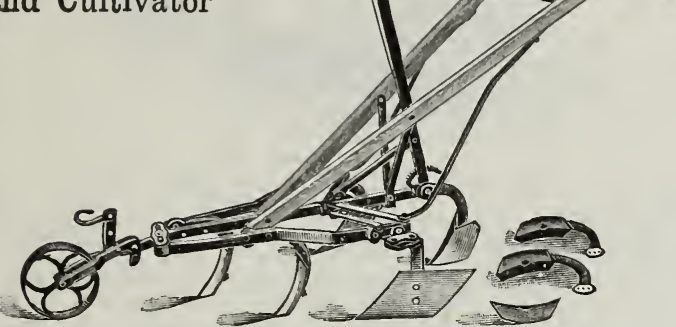

We recommend to all of cur customers as being one of the best tools made. Price, as in cut, \$7.00.

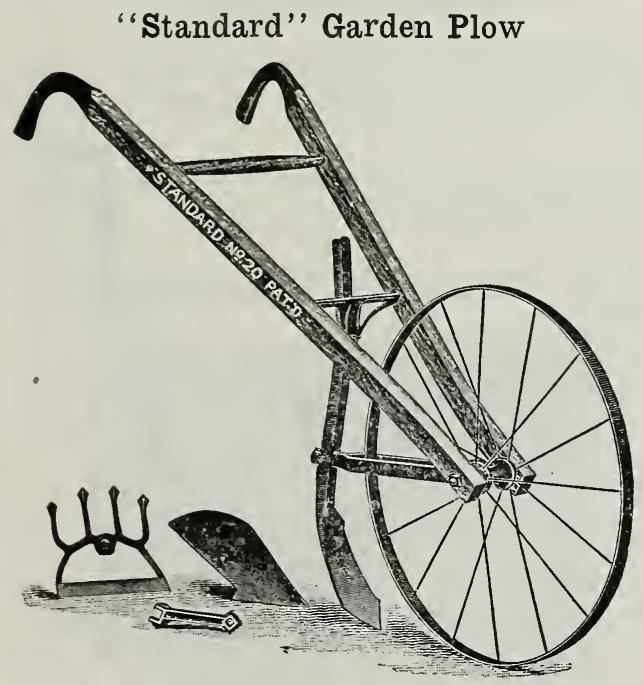

The adjustment is the handiest and most perfect ever put on a tool of this kind and is adjusted up and down. by loosening a thumb nut at the top of the shank, as shown in cut, and may be done without removing the plow from the ground. Wheel 24 inches in diameter, held by double pattern frame of very stiff steel. The handles are adjusted by the same thumb nut without interfering with the plow adjustment. These are the bent stvle handle both at the upper and lower ends making a neat fit at the axle and having good hand holds at the upper end. The attach. ments furnished with this tool are of the best quality and shape ever offered. The new hoe or sweep is a great im. provement over the other styles, scours well and does excellent work, cutting ten inches. The turning plow is the right shape to scour and run easily with no side draft. The new five-tooth rake cultivator is fine for all small plants and stirs the ground thoroughly, having wide shovel points. Price, with attachments as shown, \$4.00.

\section{Garden Trowels}

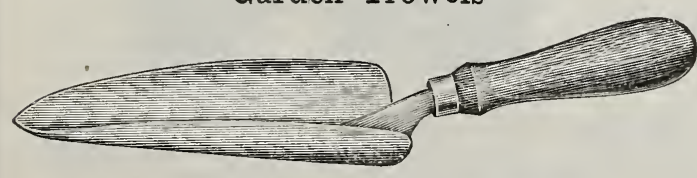

A good steel trowel. Price, 35c; postpaid, 50c.
Cronk's Cultivator Hoes

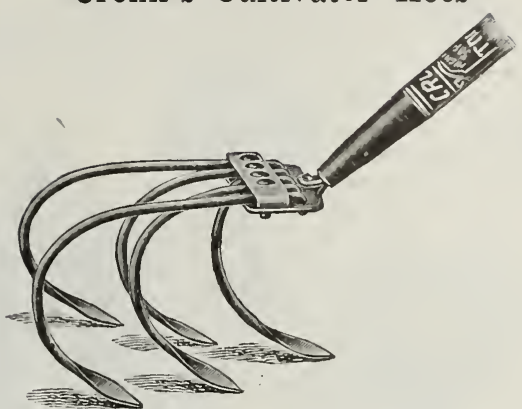

Two prongs are changeable for rows of any width. Loosening nuts, releases the prong. Works between rows or center prong can be removed and rows straddled. A perfect weeder and pulverizer, giving level cultivation. Removing center prong and reversing other four makes Potato Digger. Head made entirely of steel. Light. well made, serviceable. Blue finish, $41-3$ foot handle. Price, $\$ 1.00$.

The Right Tool in the Right Place

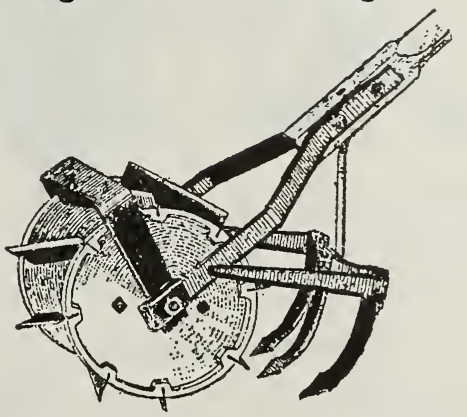

The Barker Weeder and Mulcher

This cultivator is built on the plan of a lawn mower, runs like a lawn mower and cuts weeds like a mower cuts grass. It cuts the weeds that are under the ground as well as those on top of the ground, thus doing away with two or three crops of weeds at one and the same time. The mulching and cultivating of the soil serves a twofold purpose as it breaks up the capillary and prevents the moisture from evaporating. It also keeps the surface in such a condition that it readily takes the surplus water in as it falls. Price, $\$ \mathbf{3 . 5 0}$.

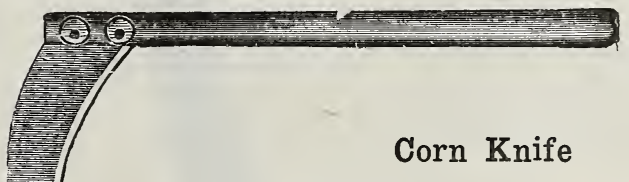

The old fashion crooked corn knife with a wood handle. Price, 50c.

\section{Lang's Weeder}

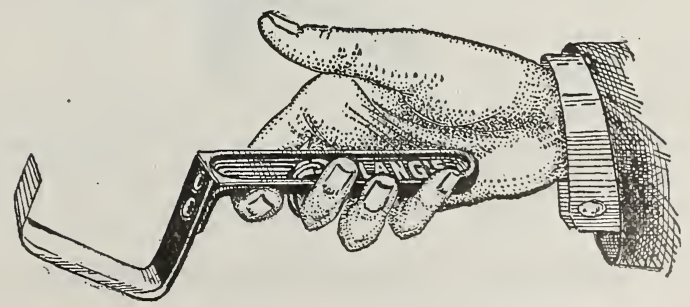

It is very conveniently used, and fits the hand so comfortably that the fingers are entirely free for use wherever necessary. Net price, 25c; postpaid, 30c. 


\section{Master's Rapid Plant Setter}

The only hand mechanical plant setter on the market. It is built on scientific principles throughout. The conical jaws are made of heary sheet steel and the main body or water reservoir and plant tube of heary tinned ulate. The water valve is of brass with rubber packing. The valve rod and trip springs are of steel wire. The machine is well put together with rivets and solder and should last for years.

Plants are set in water or liquid manure and covered at one operation. Plants may be safely set out in hot, dry weather. Sets cabbage, cauliflower. tomatoes, sweet potatoes, sugar beets, etc., much more rapidly than by hand and with much less loss of plants. The plant setter has a record of more than ons plants to grow out of each 1.000 set.

Any man can easily learn to set from 2.000 to 10.000 plants per day.

This system of planting is recommencled as proof against cutworms. Weight, crated for shipment, $71 \frac{1}{2}$ lbs. Price, $\$ 4.00$.

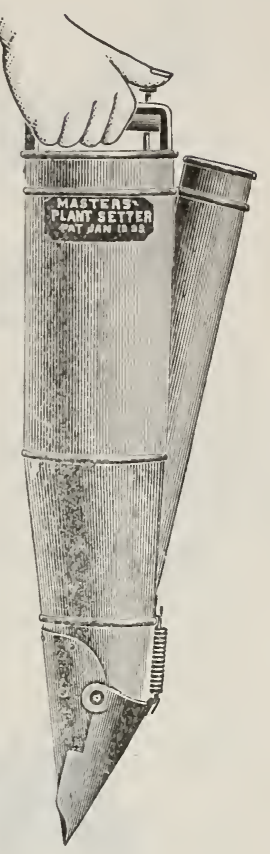

\section{Potato Planters}

EUREKA-This is the lightest and best tubular planter made. With this planter one man can plant several times as much ground witlout getting a lame back as he can plant by hand. The planter locks itself as it is lifted out of the ground, so that the next potato may be dropped in at once and opens automatically as the top of it is moved forward in walking. Price, \$1.25.

\section{BLACK HAWK CORN SHELLER A Sheller That Shalls}

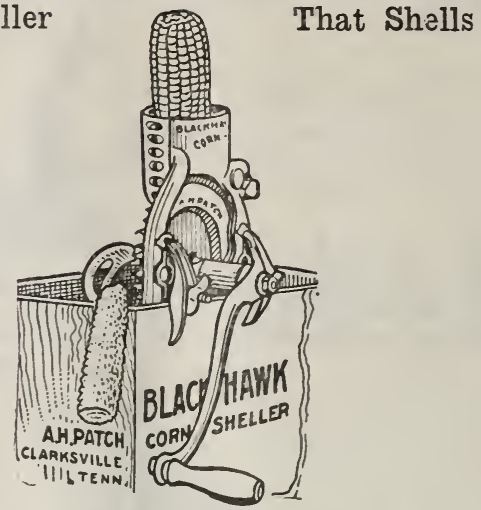

It can be set to shell any corn that grow's. Set it for popcorn and it will shell popcorn; set it for field corn and it will shell field corn; set it for the largest corn that grows and it will shell the largest corn that grows. That is why it is so much better than other trpes. Nade with ball-bearings, obviating the expense of a heavy balance wheel. Easily fastened to box by thumb-screws-no bolts nor screws required-no holes to be bored. Price, \$2.50.

\section{CORN PLANTERS}

SEGMENT CORN PLANTER -The seed pocket can be sut ficiently eularged to perfectly adapt it for planting the largest field beans as well as corn. The slide is an arc of a circle haring its center where the jaws are pivoted together. In other words, the pivots on which the jaws open and shut are the hub of a wheel of which the slide is a part of the rim. There is consequently no friction nor lost motion. Price, \$1.25.

THE ECIIDSE ROTARY C O R N PLANTER-Decidedly the best hand corn planter made and a very desirable im plement for those who have a quantity of corn to plant. It puts the corn exactly where you want it, and at a proper depth. It is easily worked and a mosi satisfactory tool in every way. Price, \$1.25.

TRIUMPH CORN PLANTER-Has no obiectionable features; is made of good material. Has Iron Seed Box and Iron Channel: foot of polished steel, strong, durable, and gives um versal satisfaction. Price, \$1.00.

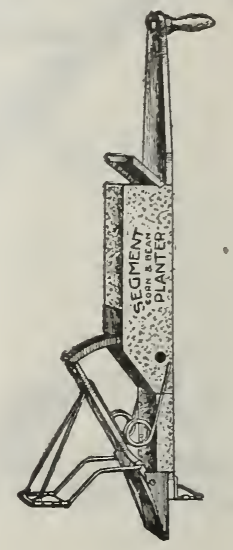

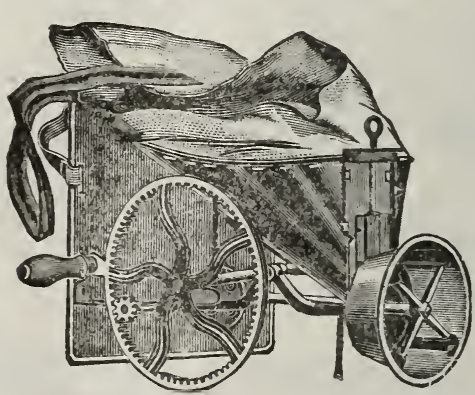

\section{"Lightning" Grass Trimming Shears}

For trimming ground, flower beds, etc. Weight, $1 \mathrm{lb}$. Each, 氵0c.

IMPROVED CAHOON-This is probably the most popular broadcast sower on the market. They have a force feed and throw the seed from 1.j to 36 feet, according to the seed that is being sown. Price, \$3.50. 


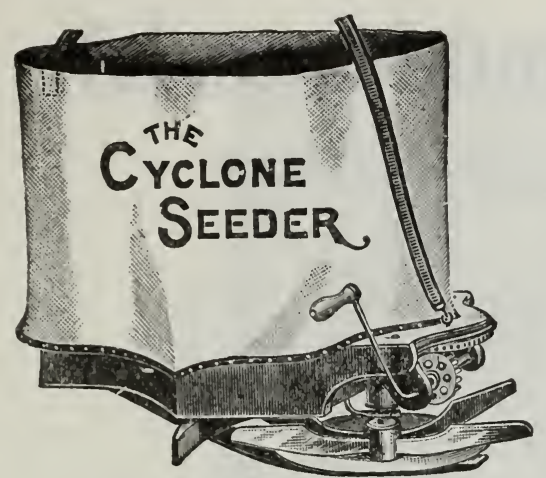

The New Cyclone Seeder

Will sow timothy, clover, oats, red top, turnip. millet, corn, cotton, and all other grains and seeds perfectly even and any desired amount to the acre, and from 40 to 60 acres a day. Price, \$2.00. Weight, $3 \frac{1}{2}$ lbs.

The Greatest Exterminator of All Animals That Burrow in the Ground

The Chemical Squirrel Tube is endorsed by the Pullman College and Moscow Univrsity.

DIRECTIONS FOR USE-The chemical used is carbon bisulphide. Fill tube two-thirds full of old sacks or any kind of waste, saturate with chemical, and blow fumes in the hole.

\section{THE CHEMICAL SQUIRREL TUBE}

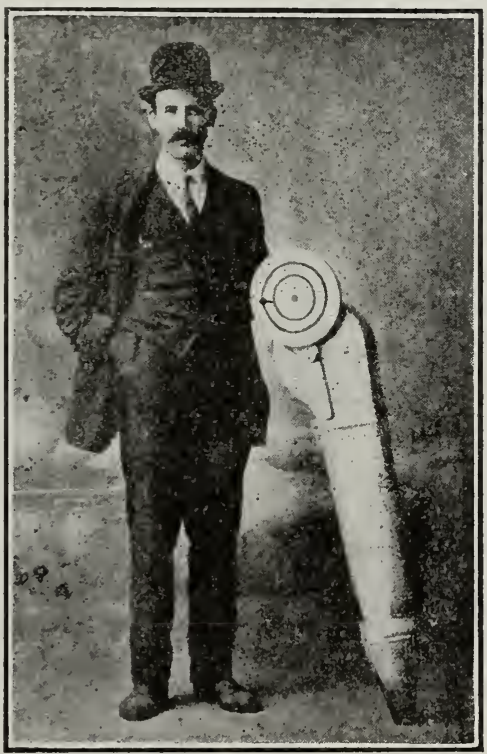

DO NOT LIGHT, AS IT WILL EXPLODE-For smoking, old sacks or dry manure has no equal. With about one pint of sulphur to each load this can be used with very little cost to the farmer.

Fifty cents' worth of sulphur will clean 100 acres of badly infested land.

Fill in all holes that smoke escapes from.

If directions are followed success is sure.

Price, \$10.00.
DE LAVAL CREAM SEPARATORS

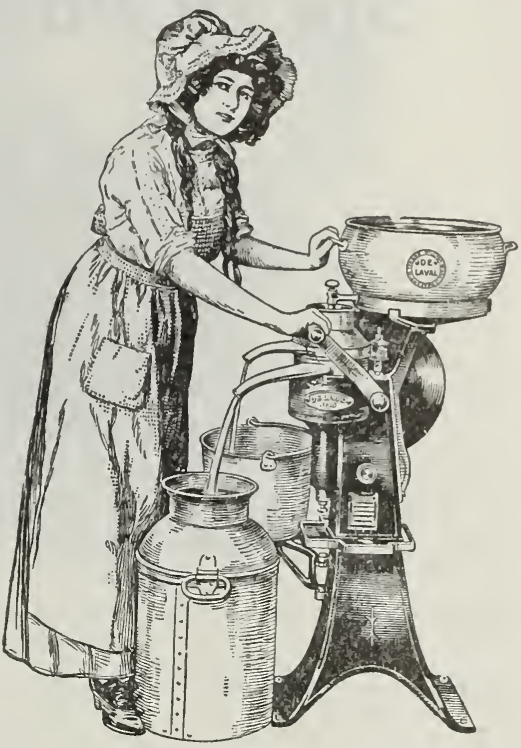

Skim cleanest, turn easiest, easiest to wash, simplest in construction, last the longest.

The De Laval was the first cream separator in 1878 and it has been first ever since.

More De Lavals are in use than all other makes combined. 98 per cent of the world's creameries nse the De Laval exclusively.

The machine that is best for the creameryman is best for the dairyman.

De Laval hand-size machines range in capacity from 1,350 to 135 pounds per hour and in price from $\$ 160$ to \$35- - seven sizes.

The De Laval is by far the most economical cream separator and always give satisfaction.

If you expect to buy a cream separator send for the latest De Laval catalog, explaining in detail the construction and points of superiority of De Lavai machines, or, better still, let us set up a De Laval for you on your own place and give the machine a trial.

\section{Separator Oil}

Price: $1 / 2$ gallon, 55c; gallon, 75c.

\section{Dairy Thermometers}

Price, 35c; postpaid, 45c.

How to make the Dairy Business pay?

Have a good pasture for your cows in the summer, with good water.

Build a Silo and fill it with ensilage corn for Winter.

Have a warm, well-kept stable.

Buy a De Laval Cream Separator. 


\section{Spray Pumps and Material}

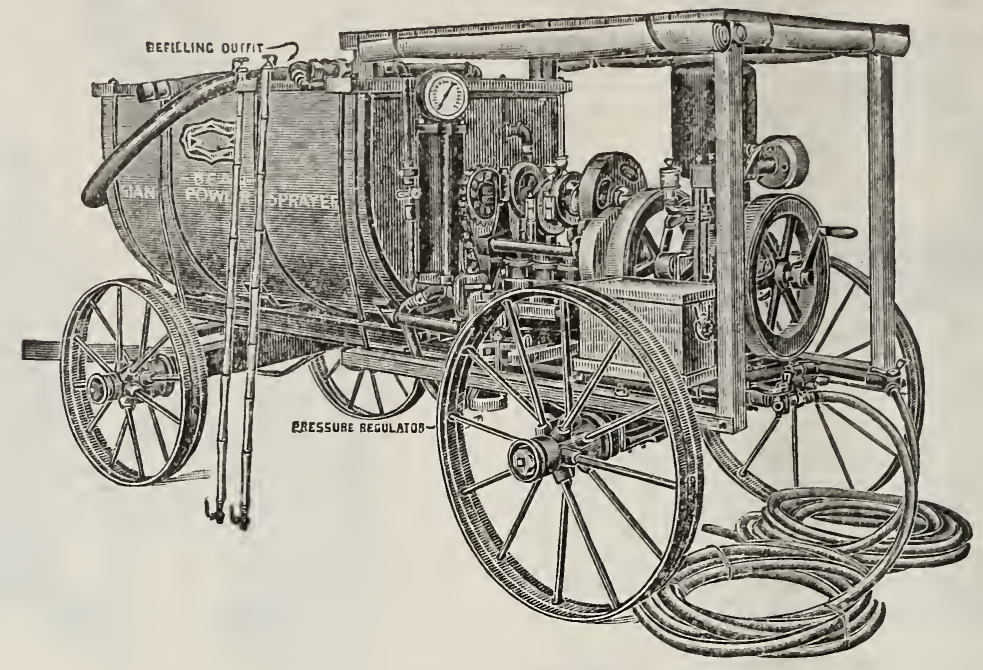

\section{BEAN GIANT TRIPLEX}

The Bean Giant Triplex is the most perfect, complete, and thoroughly efficient high-pressure power sprayer ever offered to the fruit grower. Every detail of material, construction, and workmanship is of the highest grade obtainable. It is the result of thirty years of sprayer building.

\section{The Giant Three-Cylinder Pump}

Fitted with porcelain-lined cylinders. This pump has a capacity of 8 to 11 gallons a minute. The bell metal ball valves can be reached in ten seconds. These valves operate on reversible brass seats that can be easily turned over when worn on one side, and replaced when worn on both.

\section{The Bean Pressure Regulator}

A method of pressure control that does away entirely with all relief valve troubles. Simple, durable, automatic. Absolutely sure. Saves wear on engine; saves wear on pump; saves gasoline.

\section{The Bean Refiller}

Fills the tank in five minutes. Simple, sure, thoroughly satisfactory. There is not a movable part to the Bean refiller. All that is necessary to fill the tank is to shut off nozzles, throw suction hose into the tank of liquid or into the ditch or stream, and turn on the $3 / 4$ inch cut-off.

\section{Other Bean Giant Features}

Direct Connected Agitator-Insures positive and thorough agitation of solution.

Truck-Low down. Mounted on axles direct. Fourinch depressed tires. Capacity of 4,000 pounds.

Platform-Steel, reinforced, one-piece continuous, assuring absolute rigidity.

Outfit furnished with $21 / 2$ H. P. or $4 \mathrm{H}$. P. Sprayer Engine; 100 feet of Bean Spray Hose in 50 -foot lengths; Hinged Wood Cover with Canvas Sides, etc. See our catalog.

\section{For Complete Description and Prices Write for Catalog}

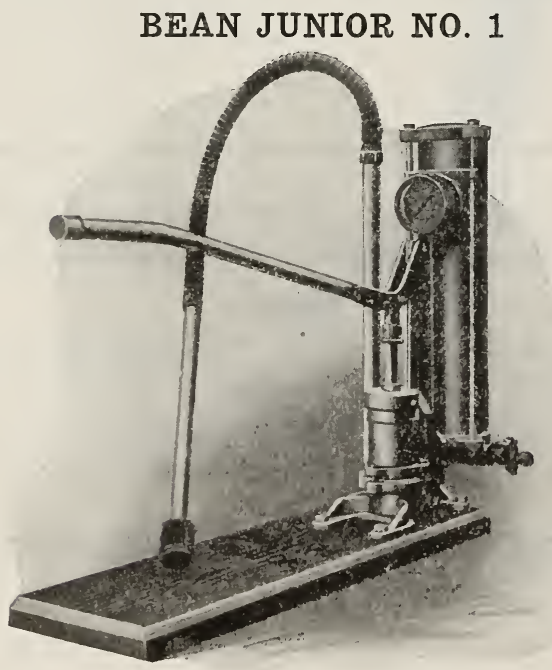

\section{Good Capacity; Low in Price}

Owners of small orchards who desire high pressure with economy will find the Bean Junior a thoroughly reliable, efficient and inexpensive pump.

\section{Many Advantages Over Barrel Pumps}

It supplies a large amount of air to the receptacle, making the pump easier to operate, the pressure uniform and the spraying more effective. In a barrel pump no air can be supplied except that naturally in the air chamber, which works out during the day and leaves no air cushion in the pump.

\section{Price List}

OUTFIT 211-Junior No. 1 Pump, on platform, with pressure gauge, suction hose, strainer, and single cut-off, $\$ 27.00$.

OUTFIT 212 -Junior No. 1 Pump, on platform, with pressure gauge, suction hose, strainer, singie cut-off and one 8-foot bamboo extension, with nozzle and cut-off, \$29.00.

COMPIETE OUTFIT 213-Junior No. 1 Pump, on platform, with pressure gauge, suction hose, strainer, single cut-off, one 8-foot bamboo extension, with nozzle and cut-off and 25 feet of our Bean Spray Hose, fitted, \$34.75. 


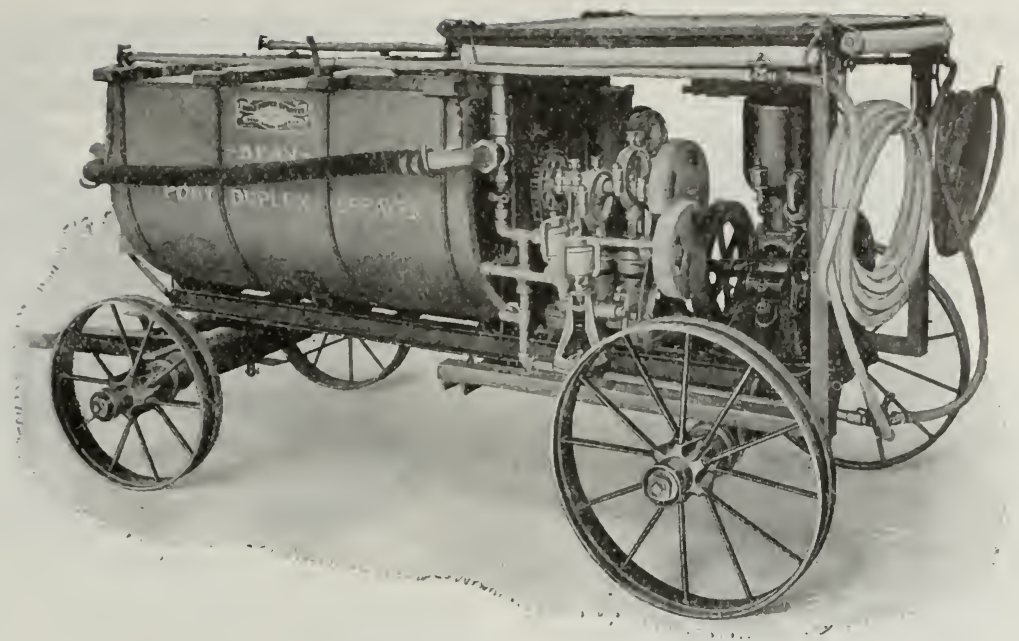

\section{THE BEAN PONY DUPLEX}

A new addition to the Bean family this season. For the orchard of moderate size the Bean Pony Duplex will meet all requirements. It has a capacity of $43 / 4$ gallons per minute at a guaranteed pressure of 200 to 225 pounds. This outfit is equipped with 2 cylinders, same as the Giant Duplex except that the cylinders on the Pony are slightly smaller, being $2 \frac{1}{2}$ in. size.

Complete Rotary Agitator-Fitted in tank and direct connected to pump.

Steel Platform-Special, narrow, one-piece steel plat- form. Absolutely rigid. All parts are connected up and fastened in position.

Hinged Wood Cover-With canvas sides and end, covering engine and pump. Fitted with hooks for carrying hose and rods.

Engine-1 1/2 H. P. Sprayer Engine, hopper cooled, with pulley and complete jump spark battery equipment.

Outfit-Fitted with 50 feet of Bean Spray Hose in 25foot lengths, unless otherwise ordered; two 8,10 or 12 foot aluminum bamboo extensions with 2 nozzles and 2 cut-offs. Extra packing, valve seats, engine springs, etc.

\section{For Complete Description and Prices Write for Catalog}

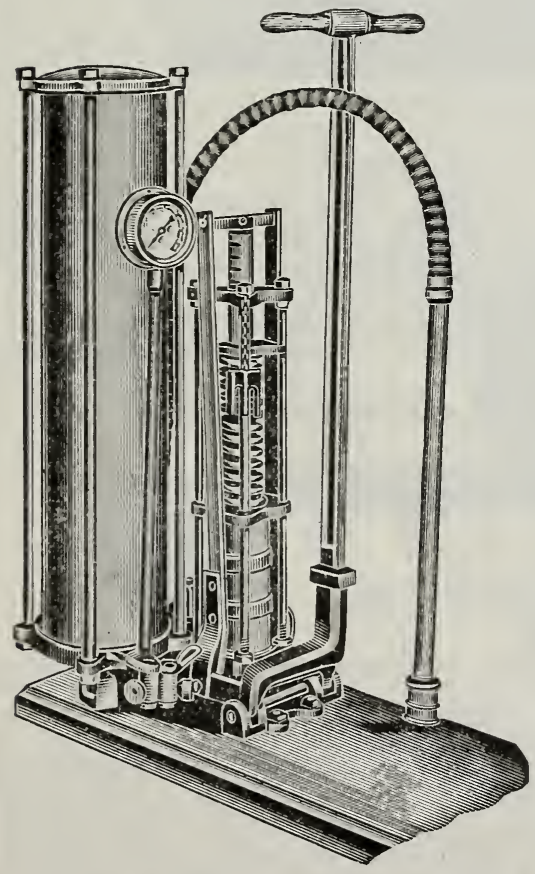

The Magic Spray Pump

\section{THE MAGIC SPRAY PUIMP For the Man Who Thinks}

Our Magic Pumps represent a principle in construction, originated, patented and controlled by us and found in no other spray pumps.

The advantage of this construction, when the pump is seen in operation, will be instantly appreciated by every fruit grower who believes in thorough spraying.

It means maintaining the high pressure that is absolutely essential with only two-thirds of the labor necessary with any other pump.

In addition to this overwhelming superiority the Magic and other Bean Spray Pumps are the only ones which-

Have non-corrosive porcelain cylinders, 3 -inch:

Have no stuffing box or outside packing.

Have 51-16 inch bell metal ball valves with reversible and removable seats;

No threads inside the valve:

Have a powerful spring, which is so used as to save one-third the labor:

Have few working parts and all of these readily accessible;

Weight 200 pounds.

These and other advantages fully described on the following pages.

\section{Price List Bean Magic No. 9}

OUTFIT 181-Magic Pump, on platform, with gauge, double cut-off, suction-hose and strainer, \$41.00.

OUTFIT 1S2-Magic Pump, on platform, with gauge, double cut-off, suction-hose and strainer, two 8 or 10 -foot bamboo extensions with cut-offs and nozzles, \$45.00.

COMPLETE OUTFIT 1S3-Magic Pump, on platform, with gauge, double cut-off, suction hose and strainer, two 8 or 10-foot bamboo extensions, with cut-offs and nozzles, and two 25-foot lengths of Bean Spray Hose, all fitted, $\$ 56.00$.

For aluminum instead of iron pipe in bamboo extensions add for each rod $\$ \mathbf{1 . 5 0}$. 


\section{BEAN “PIPPIN'” NO. 50}

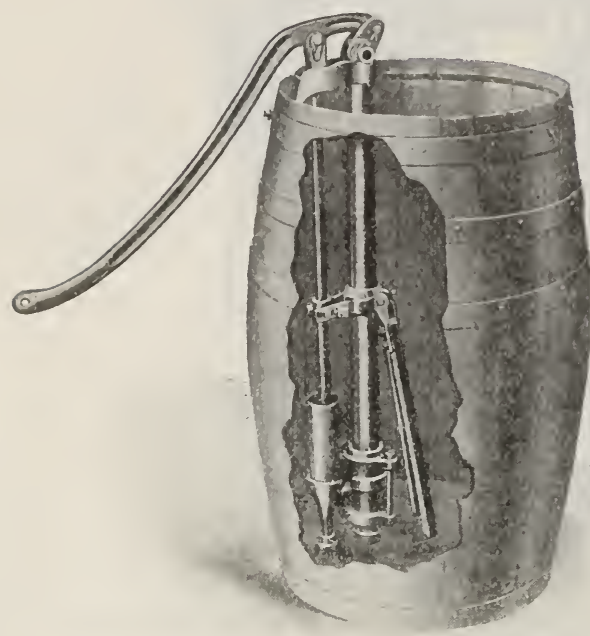

Our Bean Pippin, No. .0, is especially adapted for use on side hills and rery rough ground, beeause the air clamber is entirely contained within the barrel, so it is almost impossible to tip over.

It also meets the demand for a low-priced, high-class sprayer for small orchards, vineyards or whitewashing jobs

It has an anchor in the bottom of the barrel on which the point of the cylinder rests, which holds it rigidly in position. It is made to fasten in a barrel without a head, so is extremely easy to mount.

OUTFIT 270-Pippin No. 50 Pump, with agitator com plete, anchor, hose nipple and bolts ready to fasten to barrel. Price, $\$ \mathbf{1 1 . 0 0}$.

OUTFIT 271-Pippin No. 50 Pump, with agilator complete, anchor, hose nipple, bolts ready to fasten to barrel and one 8 -foot bamboo extension, with nozzle and cut-off. Price, $\$ 13.00$.

COMPLETE OUTFIT 272-Pippin No. 50 Pump, with agitator complete, anchor, hose nipples, bolts ready to fasten to barrel and one 8 -foot bamboo extension, with nozzle and cut-off and 20 feet of Barrel Spray Hose fitted. Price, \$16.40.

If desired mounted in barrel add to above prices \$2.25.

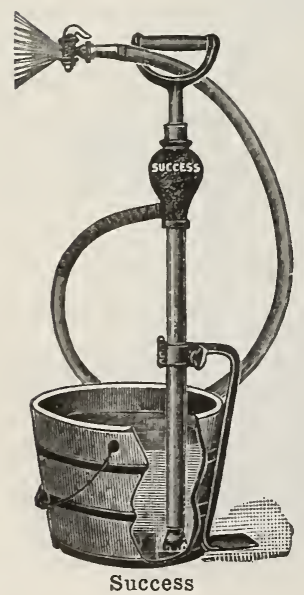

\section{The Success Bucket Spray Pump}

All Brass Working Parts, with Indestructible Bronze Valves, Malleable I $r$ on Combination Foot-Rest

Florists, gardeners, $f \mathrm{r} u$ it growers and farmers who wish a durable, convenient s p r a pump at a low cost can find nothing better. This outfit is a most excellent one cor ordinary use in gardens, vineyards and orchards: for washing windows and buggies and for the application of whitewash. The pump has a large air chamber and is double-acting, throwing a continuous stream eith e r solid or in fine spray. It is provided with Bordeaux nozzle and four feet of discharge hose. Weight 8 lbs. Price, \$4.00.

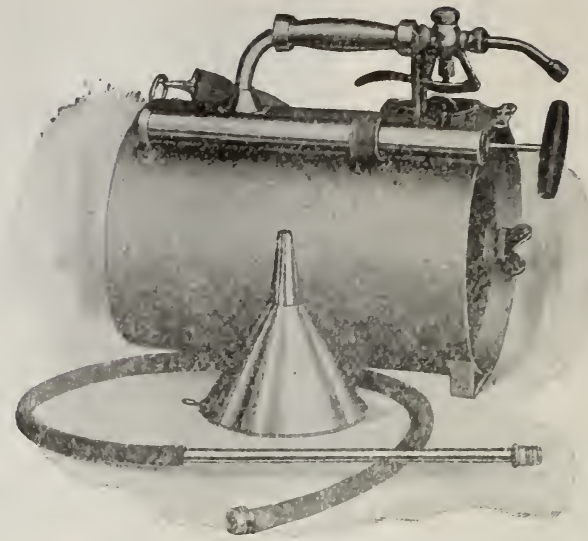

Dces not requi=e constant pumping. Has an automatic thumb lever valve. Most practical for Orchard, Field and Ga:den Work.

One pumping will expel entiro contents of tank and is sufficient to spray 2,000 plants. Spraying nozzle may be reversed to spray under side of bushes anci plants. The Automatic Thumb Lever valve is at all times under com plete control of operator--hence none of tile solution is wasted. It saves its cost in making a given amount of compound do so much work. An adjustable shoulder strap and tree attachment with suitable enuplings for orehard and tree spraying furnished with each marhine. Aluminum finish. Capacity, 3 gallons. Price, \$5.50.

\section{Inland Powder Sprayer}

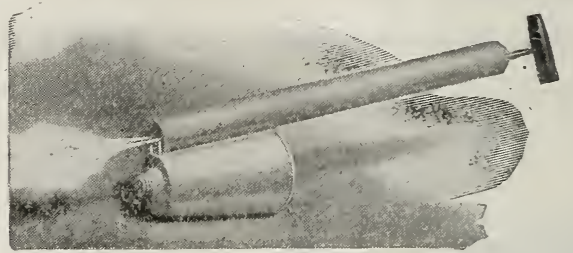

In some sections potato growers, stock and poultry raisers prefer to use Paris Green and disinfectants in powder form mixed with dry plaster. To meet such a demand the "Blow" Sprayer is recommended. It is unnecessary to give the details of the mechanical constructions of the sprayer as we give a positive guarantee with each sprayer that it is impossible to draw powder back into the cylinder pump and if the powder is sifted through a screen and kept absolutely dry it will be impossible for the same to clog. With these features covered the sprayer is sure to give satisfaction. Weight $1 \frac{3 / 4}{\mathrm{lbs}}$. Price, $\$ 1.00$

\section{Inland Continuous Sprayer}

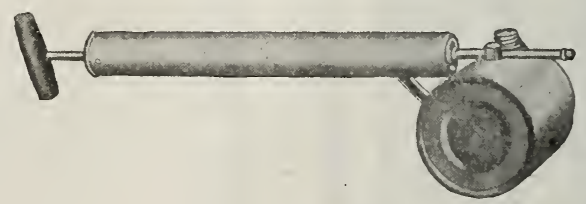

The Inland Continuous Sprayer, as the name implies, is so constructed that it not only sprays on the downward stroke of the plunger but also when it draws back, thus causing a continuous mist-like spray.

The air chamber measures $11 \%$ inches in diameter by 14 inches long. Has a $1 / 4$-inch steel plunger rod: special type plunger. The sprayer is fitted with a $3-16$ inch brass ball check valve which is positive in its action and practically indestructible. The solution tank is made from heavy IX tin and is so constructed that the sprayer will not tip over when filling. $3 / 4$-inch zine filler cap. Capacity one quart. Packed 1 dozen in case. Extra tip for spraying upwards, with each machine. Weight $11 \frac{1}{2}$ lbs. Price, \$1.09. 


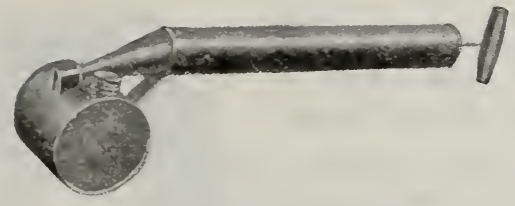

Inland Special Sprayer

Inland Special Spraser is a Single Tube Tin Sprayer. The pump cylinder measures $14 \frac{1 / 2}{2}$ inches in length by $13 / 4$ inches in diameter.

Sprayer is fitted with a $1 / 4$-inch steel plunger rod; special type plunger. The special arrangement of the spraying tube is sucl that it thoroughly breaks up or atomizes III oils and solutions into a fine mist-like spray which penetrates all cracks and crevices. The sprayer is adapted for all kinds of general spraying and is used very extensively for spraying disinfectants, etc. Weight $1 \frac{1}{1 / 2} \mathrm{lbs}$. Price, joc.

\section{DUST SPRAYERS}

The principle of spraying to control insects and diseases on plant life is right. In practice the principle advocated and taught by our theorists is unsatisfactory, unpleasant, laborious and expensire. Principles and practice go together. The results from practice determines the correctness of the principle. A theory of orchard protection against insects and fungi is of no value until the practical grower has put his $\mathrm{O}$. K. on it. The Dust Spray is championed by the successful practical growers, because it is satisfactory, rapid and easy of application, with a minimum amount of labor, and saves 75 per cent in spraying expenses.

\section{Cyclone}

This is our $\mathrm{h}$ and p ow e r machine. The dust box holds 1 peck of dust, the machine uses $2 \div$-inch air tube and 8 feet of $21 / 2$-inch spouting, o u $\mathrm{r}$ flexihle joint, stand and fixtures, and our hook of formu. las are iurnished free with each machine.

Capacity - One horse and licht wagon, and two men can spray from 25 to 40 acres per day. according to the size of the trees.

Price-Machine, $\mathbf{S}$ feet of $2 \frac{1}{2}$-inch spouting, 1 flexible joint, stand and fixtures complete, crated, \$2.̄.00.

\section{Portable}

Machine 1902
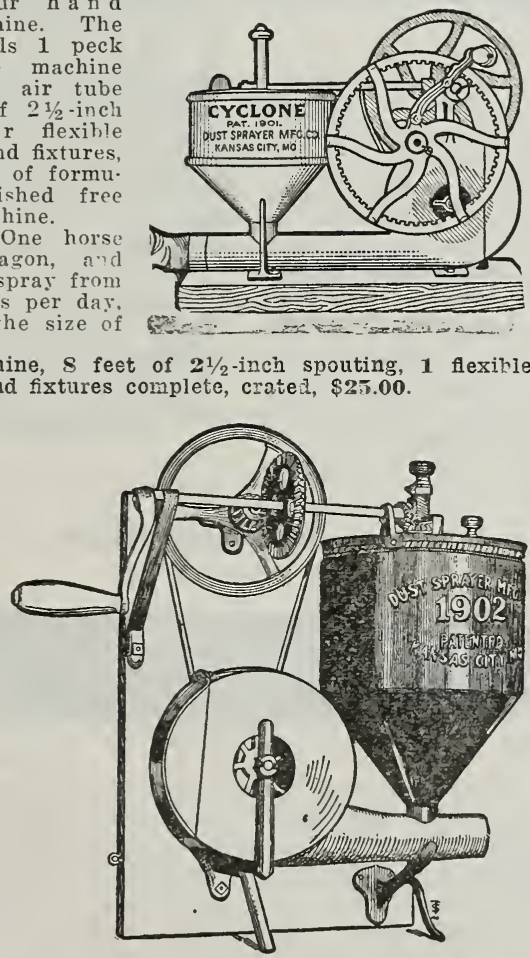

This machine is carried by the operator. The machine and its entire mechanism is securely fastened to a sinole back piece that is supported close to the body of the operator in front. It is held in position by combined shoulder braces and waist band, adjusted in such a manner as to throw the weight of the machine on the haunches of the perator.

The dust box holds 1 gallon. It has the same fred attachment as the Crclone, and guaranteed not to choke.
The dust box, air tube, and fan shell are made from galranized iron on exactly the same design as the Crclone.

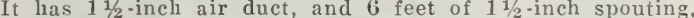
one flexible joint and one pair of combined shoulder braces with our book of formulas are furnished free with eacl machine.

Price-Machine, 6 feet of $1 \frac{1}{2}$-inch spouting, 1 flexible joint, and 1 pair combined shoulder braces, all complete and boxed, \$11.00.

PRESSURE GAUGE-Price, $\$ 2.00$.

\section{Bordeaux Nozzle}

This Bordeaux Nozzle is a new pattern which eliminates the common objections to this type. The handle is built close down to the body and is shapea so as to avoid catching in the branches. This will be quickly appreciated by all users of this style of nozzle. The weight is also materially reduced without at all reducing the strength The corners of the slot are cur away leaving plain straight faces which form a clean-cut spray without ragged edges.

Price, each, 75c; postpaid, 80c.

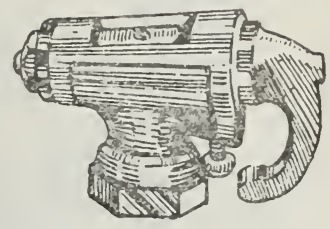

\section{Whirlpool Power Nozzle}

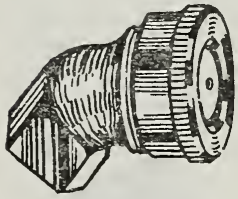

This has a very large ca pacity, and makes a perfect cone-shaped sprav. This nozzle is built on an angle of 45 degrees, allowing the operator to spray up or down by simnly turning the nozzle. Price, eacn, $75 \mathrm{c}$; postpaid, S0c.

\section{Vermorel Nozzle}

The Vermorel Nozzle throws a beautiful, misty, circular spray.

All trouble caused by clogging in the bend is avoided by having the stem detach a bie. This also allows the nozzie to be turned to any angie desired. Price, each, $75 \mathrm{c}$; postpaid, soc.

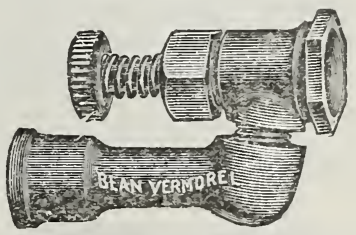

Double Vermorel Nozzle

Price, each, \$1.40; postpaid, \$1.50.

\section{Triple Vermorel Nozzle}

Price, each, \$2.00; postpaid, \$2.10.

\section{Bean Best}

"The Unequaled Cyclone Nozzle"

Throws a fine circular spray a long cular spr
distance.

Bean Best is marked improvement on our Crclone Lon Distance Nozzle and furnishes a perfect

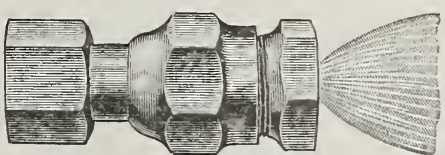
spray. There are no

parts to catch on thro is fited with a steel cap, which does not cut out easily. A second cap with larger hole is also furnished with each nozzle. Price, each, 75c; postpaid, $80 \mathrm{c}$.

\section{Bean Whitewash Nozzle \\ The old Standby for Whitewashing}

The nozzle throws a fine spray or a solid stream. It is particularly recommended for whitewashing and for washing buggies. Thousands of these nozzles are now in use and giving the best of satisfaction. To clean when clogged, turn the thumb screw straight out for an instant. Price, each, 75c; postpaid, Soc. 


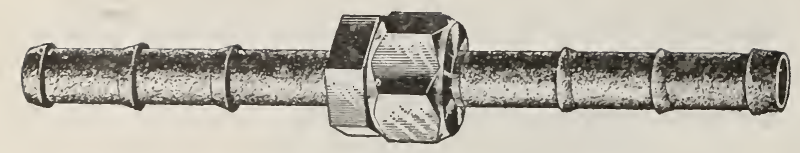

\section{Spray Hose Clamps}

Two of these clamps can be

With hexagon nuts and double length shank, so will not pull or blow out.

Price, per pair, s.sc; postpaid, 6ec.

Female half only, 30c; postpaid, 35c. used on our long shank couplings and mender. Price, each, postpaid. Per dozen, postpaid.

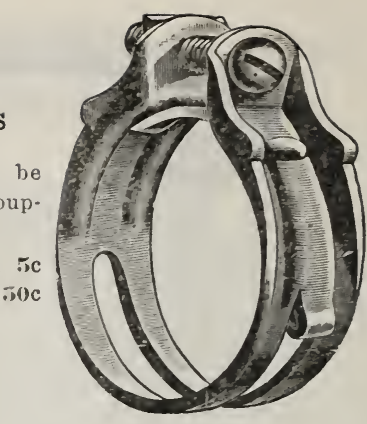

\section{Hose Connection}

To c o n n e c t 1/4-inch hose to spray rod. Price, each, 25c; postpaid, 30c.

Spray Fiose MendersEach, 20c; postpaid, 2.xc.

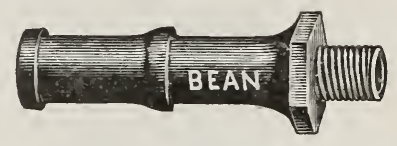

\section{$1 / 4$ Nozzle $\mathbf{Y}^{\cdot}$}

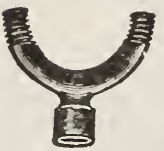

The Brass $Y$ shown here will screw on on any spray rod, and all kinds of spray nozzles serew into the other two ends. This is intended for use when two nozzles on one rod are desired.

Price, each, 60c; postpaid, 65c.

\section{1/4 Nozzle Ell}

It is very important to spray down into the blossom. This piece has just the right angle and screws onto the end of any spray rod. Then attach the nozzle.

Price, each, 25c; postpaid, 30c.

\section{Three-Way Discharge Cock}

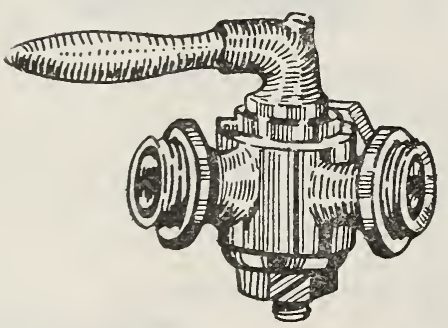

This has a large barrel which allows it to cut off abso. lutely, and eliminates the trouble that has $b$ e e $n$ experienced with in ferior cocks. Price, each, \$1.50; postpaid, $\$ 1.75$.

\section{Spray Cut-Off}

This $1 / 4$-inch shut-ofi is for use on spray rods in piace of globe valves. Shuts liquid off instantly, saving time and material. Can be put on any rod.

Price, each, 60c; postpaid, 65c.

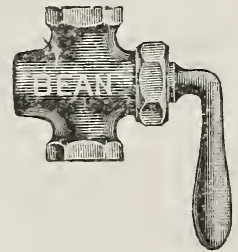

\section{Bean Ball Rod Cut-Off}

The perfect 1/4-inch rod cut-off. Far better than a globe valve for it opens full with less than one turn of handle. Better than any lever cut-off because it will not leak since the ball revolves instead of wearing. Fits any spray rod, Price, postpaid, \$1.10.

\section{Hose Reducers}

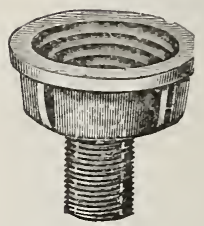

These are for connecting a male hose coupling on end of spray hose to the spray rod. The two-piece connection has a swivel joint and is easy to attach. When the one-picee connection is used the entire rod must be turned in screwing on. Price, one-piece reducer, 20c.

\section{Bamboo Extensions}

The bamboo used in making our extension is a nice size to hold in the hands and is smooth and little affected by either heat or cold. We regularly fit them with $1 / 8$-inch iron pipe, but can furnish $1 / 4$-inch iron pipe without extra charge; $1 / 8$-inch pipe is perfectly smooth, does not rust or corrode, and weighs only one pound to ten feet.

8-goot Bamboo Extension, with iron pipe, \$1.50; with aluminum pipe, \$2.50.

10-foot Bamboo Extensions, with iron pipe, \$1.75; with aluminum pipe, $\$ 3.00$.

12 foot Bamboo Extension, with iron pipe, $\$ 1.90$; w1th aluminum pipe, $\$ 3.50$.

1/4-inch Extension Pipe Rod only, $5 \mathrm{ft}$., 60c; $8 \mathrm{ft} ., 75 \mathrm{c}$; $10 \mathrm{ft} ., 90 \mathrm{c}$.

\section{Bean Spray Hose}

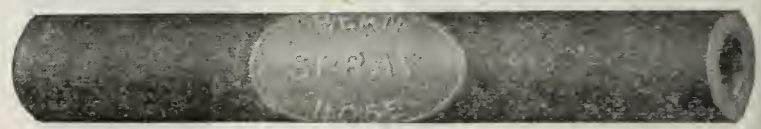

The high pressure and corrosive and oily maierials usea in spraying are very destructive on ordinary spray hose, and hare caused many persons to believe that hose for this purpose cannot be relied upon to last out a season's hard usage. Our bean Spray Hose is constructed and treated on purpose for this use, and as it saves annoyance, and lasts longer, it is much more economical. Furnished in 25) and 50 foot length, fully guaranteed. Price, with couplings attached, per foot, 23c.

Our Barrel Spray Hose is good, but is for lighter pressure. Price, per foot, 15c.

Hose Washers, 1/2-inch rubber, per doz., 10c. 


\section{Spray Materials and Insecticides}

The Two Greatest Fruit Tree Sprays

For Destroying Insects, Scale, Etc.

Lime and Sulphur Solution

and

\section{Arsenate of Lead}

The secret of successful spraying lies in knowing and judging the correct time based on climatic conditions. Certain locations are much warmer and earlier than others; more adranced. Owing to this fact orchardists must watch these conditions and use their judgment as to when to spray for the different diseases.

Kindly bear in mind this very important fact that thoroughness in spraying is one of the main points. Many failures call be traced to the lack of thoroughness.

It is also important that the orchardist should become familiar with the name and character of the disease he is to spray for. If the disease is not known apply to your inspector for information. Specimens of diseased fruits or leaves, or other portions of trees or plants, may be forwarded to your state experiment statin at no cost, where a careful microscopical examination will be made and the disease identified.

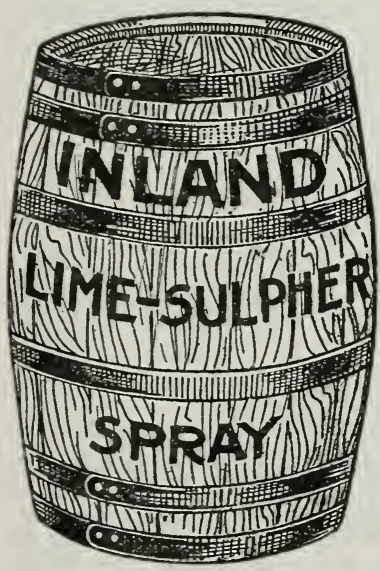

LIME AND SULPHUR SOLUTION makes for better fruit. It means a big earning power. It is a true calcium sulphide a true calcium sulphide means a periect chemical combination of lime and sulphur, absolutely free from all sediment, absolute uniform. ity which guarantees the same identical treatment as to strength and effect tree for tree, and which allows the wash to be applied to delicate bud life, blossom condition and foliage as well as the dorman tree, without injury or setback, both for fungicidal and insecticidal troubles as well as San Jose Scale. Oys ter Shell Bark Louse Moss, Apple and Pear Scab, Slug Words etc. The wide range of dis ease that fruit trees are subject to that it will control, prove it to be the best general fruit wash the world has any record of.

\section{Directions}

For any Scale Insects, or Bark Louse, Moss, Lichens, Green Aphis, or Red Spiders, use one part with ten to twelve parts water; spray when leaves are off the trees.

For Bud Moth, Peach Twig Borer, Woody Aphis, Peach Leaf Curl, Peach Mildew, Apple Mildew, Grane Mildew, use one part to ten or twelve parts of water; spray when buds are swelling.

For Apple Scab and Peach Scab, use one part with fourteen of water; spray just before blossoms open, again as soon as blossoms fall.

For Black Spot Canker, use one part with ten parts water; spray as soon as the leaves fall, repeat in two weeks.

In using as a summer spray, use one part with twenty parts water.

Price, gallon, 75c; 5 gallons, \$2.25; case, \$1.25; barrel, \$10.00; for large quantities, write for price.

\section{To All Poultry Raisers}

Of Great Importanc-Lime and Sulphur Solution diluted 1 to 5 , one gallon to five gallons of water for spraying your poultry house for destroying Lice, Mites and Vermin, will outclass any other product for like purpose on the market, and is sprayed for one-tenth the cost.

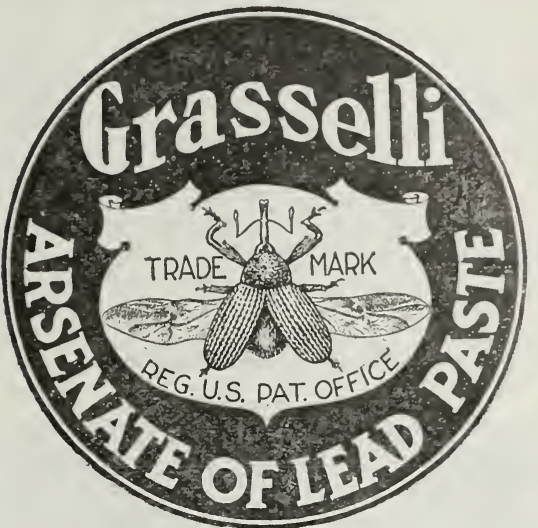

The superior qualities of this article as an insecticide are already well known. A few words upon this point, however, may not be out of place.

As the name implies, Arsenate of Lead is a chemical combination of lead and arsenic. The arsenic is the poi soning agent. The lead serves two purposes-it acts as a binder, holding the arsenic upon the foliage and forms a strong chemical union with the arsenic, reducing to the minimum soluble arsenic, which causes foliage injury.

Grasselli Arsenate of Lead-Paste contains 15 per cent arsenic oxide, combined with the maximum amount of lead consistent with good mixing qualities. It contains less than $3 / 4$ of 1 per cent soluble arsenic and will not injure the most delicate foliage when used according to directions.

\section{Grasselli Arsenate of Lead}

Kills all leaf-eating insects. Does not injury the foliage. Mixes readily with water. Sticks to the foliage.

Grasselli Arsenate of Lead conforms to the most rigid requirements of Nationa and State Laws gorerning the manufacture and sale of insecticides.

Prices-One 1b., 25c; 5 lbs., \$1.10; 10 lbs., \$1.50; 20 lbs., \$2.50; 50 lbs., \$5.50; 100 1bs., \$10.50.

Winners of the Capital prize for our National Apple Show for 1908, 1909 and 1910 used Grasselli's Arsenate of Lead.

\section{Grasselli Bordeaux Mixture Paste}

A fungicide for Potato Blight, Potato Rot, Mildew, Leaf Blight, Cutworms, etc Before bloom use 1 lb to 6 gallons of water, after bloom use $1 \mathrm{lb}$. to 10 gallons.

Price, 1-1b. jar, 35c; 5 lbs., \$1.25.

\section{"BLACK LEAF 40"}

A Concentrated Solution of NicoteneSulphate (Poison)

For the convenient information of those desiring iu employ "Black Leaf 40"' for spraying fruit trees, vege tables, etc., the following suggestions are made:

Against sucking insects, such as Green and Woolly Aphis, Pear Psylla, Grape Leaf Hopper, Pear Thrips, etc. 1 part "Black Leaf 40 " to about 900 to 1000 parts water. Against more resistant plant lice, such as Black Aphis and Rosy Apple Aphis, 1 part "Black Leaf 40"' to about 500 or 700 parts water.

To obtain best results, use strong pressure whenever practicable, particularly against insects having a waxy covering, or to penetrate openirig buds.

The addition of one or two pounds of any good laundry soap, or of Whale Oil Sap, to each 50 gallons of water is often very advantageous, lessening the formation of drops, and causing the spray to cover surfaces more in the form of a thin film; also to give better penetration. When using, dissolve the soap in the water before adding 'Plack Leaf 40 .'

Price, $1 / 2-1 b$. tin, by express or freight, S.ic.

Price, 21/2-lb. tin, by express or freight, \$3.25.

\section{Tobacco Extract}

Liquid, free from gum. Destroys plant lice of all kinds. red spiders, sheep ticks, etc. For syringing, dilute 20 times or more with water. The finer the spray, the better. Price, $1 / 2$ pt., 35c; pt., 60c. Not mailable. 


\section{SPRAY CALENDAR}

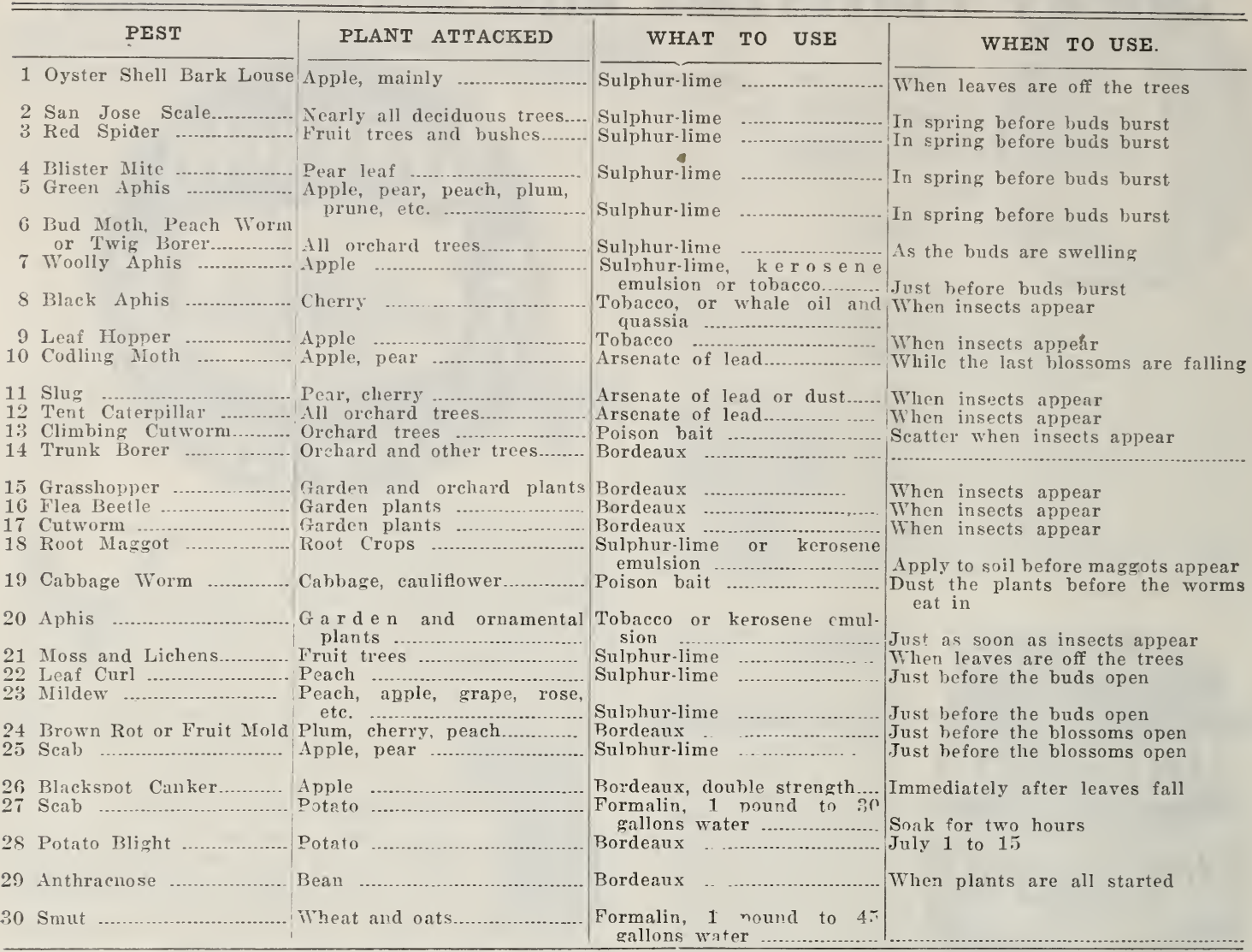

\section{Nico-Fume Tobacco Paper}

For fumigating greenhouses and other places where fumes can be confined. Considered indispensible by our most successful greenhouse men.

Price, 24 sheets, 75c; 144 sheets, \$3.50.

\section{TREE TANGLEFOOT}

To protet trees against climbing insect pests in a simple, economical ana effective way, us e Tree Tanglefoot - a sticky substance ap plied directly to the bark of trees. One application remains sticky three to four months fully exposed to the weather. Eas. ily applied with a wooden paddle. une pound makes a band 8 to 9 feet long. No mixing. always ready for use.

Will not injure trees. Is far supe rior to hurlap bands, which require daily inspection to $\mathrm{g}$ i $\mathrm{v}$ e p a r t i a l protection.

whereas Tree Tanglefoot bands require only occasional in. spection to give absolute protection.

Price, 1-pound can

Price, 3-pound can

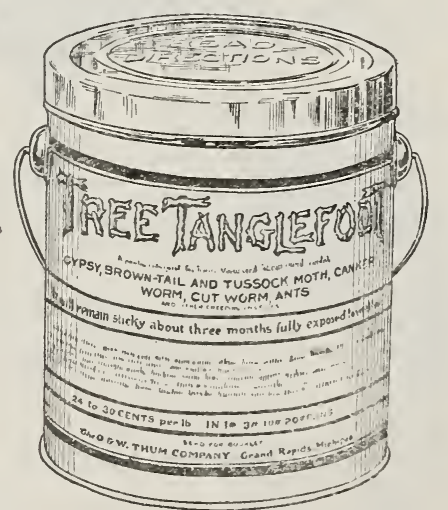

\$0.313

.85

\section{FORIIALDEHYDE}

\section{A Sure Preventive for Smut in Grain}

This has proved to be much better than vitriol, etc., for treating grain to prevent smuit. Also potatoes for blight and scab. Formaldehyde is sold by the pound; one pound is sufficient to treat 40 to 50 bushels of grain. Price, $1 \mathrm{lb}$. bottle, 40c; cannot le sent by mail.

BLUESTONE-Market price. Use $1 \mathrm{lb}$. to $5 \mathrm{bu}$. of grain.

\section{Grafting Wax}

One-half lb., 30c; 1 lb., 50c postpaid.

\section{Beeswax}

This is run in pound cacks and is pure. Price, 1b., 50c.

\section{Paris Green}

Poor Paris Green is dear at any price. The brand we handle is warranted strictly pure and will comply with state laws. Effective against all chewing insects. Onelb. pkg., 35c; 5-1b. pkg., \$1.40.

\section{Whale Oil Soap}

Used as a summer spray for hop louse and green aphis. One lib., 10c; $100 \mathrm{lbs}$., market price.

\section{Quassia Chips}

Used with Whale Oil Soap for lice on cabbage, cauliflower, etc., and on fruit trees. Lb., $15 c$. 


\section{Hellebore}

Especially used for destroying turnip, currant, and gooseberry worms, larvae of sawflies, etc. One 1b., 40c.

\section{Kerosene Emulsion}

Will kill suctorial insects. One qt., in tin cans 50c; 1 gallon, in tin cans, $\$ 1.25 ; 5$ gal., $\$ 3.50$.

\section{Hammond's Slug Shot}

For destroying slugs, cabbage and turnip flea, currant worms, etc. Per lb., 15̄c; 5-1b. pkg., 60c.

\section{Hammond's Grape Dust}

To prevent mildew on roses, grapes and gooseberries. Per 1b., 1.5c; 5-lb. pkg., 60c.

\section{Tobacco Dust}

One of the best remedies for green and black aphis, fleas, beetles. Price, 1 lb., 10c; 10 lbs., $75 c$ freight.

\section{Sulphur}

Powdered, lb., 5c; 100 lbs., market price.

\section{Bluestone}

Used successfully in winter sprays. Per 1b., 15c. If wanted in 100-1b. or barrel lots, market price.

\section{SULPHO-TOBACCO \\ Plant and Animal Soap}

A Wonderful and Inexpensive Insecticide

Sulpho-Tobacco Plant- and Animal-Soap is a powerful agent for the destruction of all bugs and insects. One or two applications will rid plants of the pests. Full directions with each cake.

Destroys, cabbage, squash, and potato bugs, currant worms, lice, green-fly, mealy bug, red spider, etc. Sure death to all plant insects indoors and out-of-doors. Of special value for spraying shrubs, fruit trees and vines. Is also valuable as a wash for dogs and other animals.

3 oz. cake makes $1 \frac{1}{2}$ gallons solution. 10c postpaid, 15c.

8 oz. cake makes 4 gallons prepared solution. 20c; postpaid 30c.
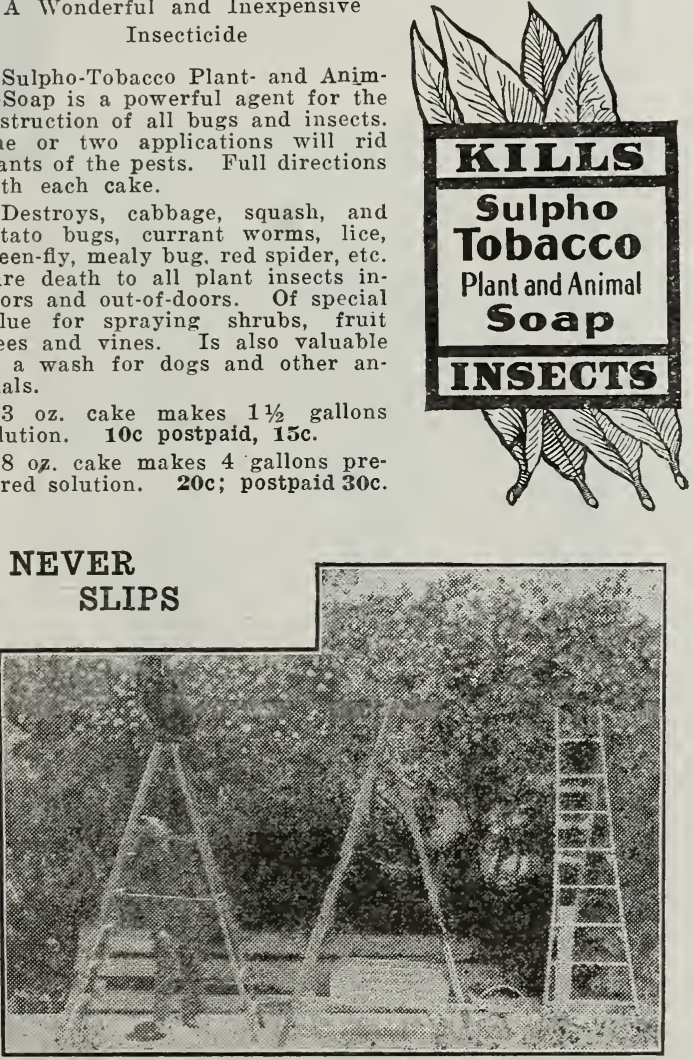

No. 2

No. 10

No. 11

See Inside Cover for Now Postal Rate.
Lightest and Strongest

Safety Combination Fruit Extensions Safety Stepladders

The Never-Slin Stepladders are constructed of carcfully selected No. 1 fir, securely nut together with bolts and screws. They have the latest improved steel head, making a ladder, light, strong and durable.

Price, No. 2 Safety Stepladder, per ft.

Price, No, 10 Safety Stepladder, per ft

Price, No. 11 Safety Stepladder (can be extended, making a pointed ladder), per ft.

\section{Edgemont Lid Press}

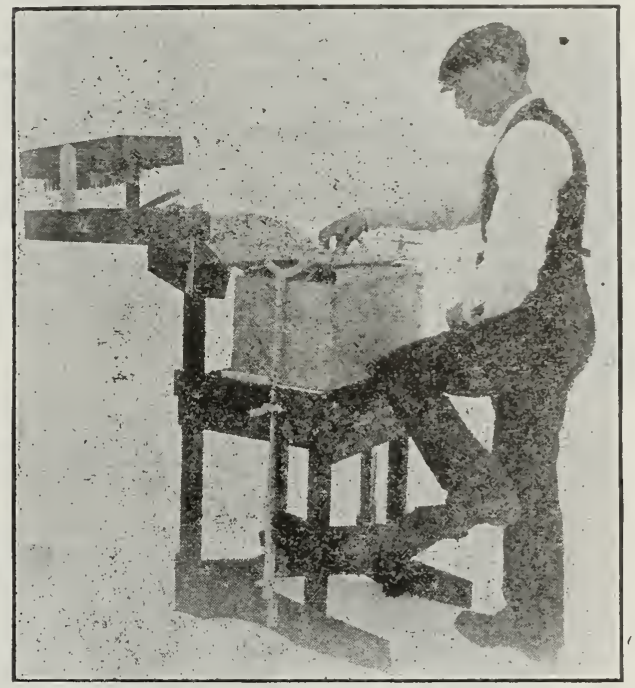

All fruit growers sooner or later feel the need of a good, durable and handy LID PRESS. In offering the Edgemont to the public we are confident that it will fill a long-felt want. It is the result of several years' experimenting, with the riew of embodying in a single machine qualities making it easily the best on the market.

SAVING TIME is just as essential in the packing house as it is in the shop or factory. A number of the special features of the Edgemont Lid Press are time savers, which are quickly appreciated by the user. The stripper nail box delivering the nails all points down; the placing of the iids in position endwise by the clamping yoke; the little spring attachment holding the cleat in place, all tend to make nailing an easy, quick and simple operation. Price, \$12.50.

\section{RAFFIA}

Natural color: for nursery work. Price, 1 lb., $25 \mathrm{c}$.

\section{TREF LABELS}

Wood, $3 \frac{1}{2}$ inch, wired. Price. 100, 15c; 1,000, $\$ 1.00$. 


\section{SPRAYOIMETER}

The Lime-Sulphur wash for spraying has be. come recognized by the orchardists as one of the best and most economic remedies for numerous forms of disease, fungi and inscets, injurious to fruit trees.

In making up this wash there are two operations: first, makin $r$ the concentrated solution from line, sulphur and water, if the product is to be home-made; and the second dilnting for use in spraying the trees.

It is necessary in eacli of these to know the strength or weight of the solution, and the only practical way of ascertaining this is by means of a Hydrometer. The Hydrometers made for this purpose are knnwn as "Sprayometers." It is practically impossible for the fruit grower to be without one, at least, as in all the methods used for obtaining data for the making of the wash, readings referred to the Hydrometer will be found. In selecting these instruments consideration should be given to the fact that only the most accurate will give the best results, and that "Taylor-Rochester", is a synonym for accuracy. Price, \$1.00; postpaid, \$1.10.

\section{THE WILSON BOTTOMLESS FRUIT BAG}

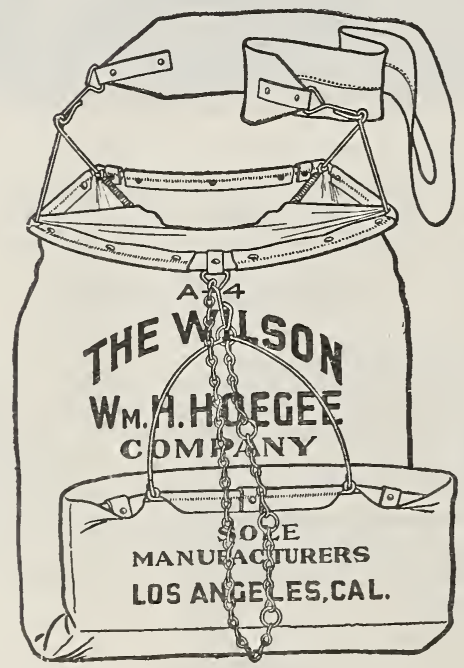

Our Canvas Picking. Bag is the best article yet introduced to facilitate the carcful and expeditious handling of apples, pears, oranges, lcmons, and other fruits that are picked and emntied into the boxes or barrels on the ground.

The mouth of the bag is lield open by a circular spring wire, which makes it easy to pass the fruit from the tree into the bag without crowding or jamming. They are hungfrom the shoulder by a strap, are light, flexible, easy to handle, weighs only two pounds, and when filled holds one-half bushel. Whon climbing into a tree the picker swings the bag behind his arm, leaving only room enough to pass in the fruit. After a trial he will agree that they are the best and cheapest gatherer made. An active apnle picker can fill and empty the bag 200 to 250 times per day, without damage to the fruit. An expert picker can even do better than that. There is no question about the economy and the advantage in handling frult with the use of the Wilson bag. $\Lambda$ good picker can pick enough more, and to a better advantage with one of these, and pay for its cost in two days. Weight, 3 lbs. Price, express or freight, $\$ 1.50$.

\section{PRUNING TOOLS}
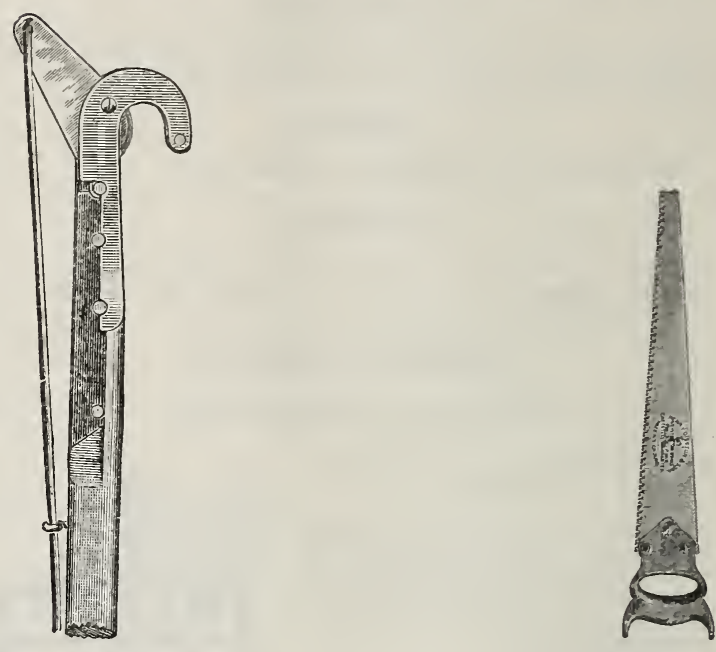

No. 20

No. 10

\section{Waters' Long Handle Tree Pruners}

No. 20-Indispensable in pruning tall trees. (See cut No. 0.) Cannot go by mail. Purchaser will have to pay freight or express charges. Price, $6 \mathrm{ft}$., $75 \mathrm{c}: \mathrm{ft}$., 90c; 10 ft., $\$ 1.00 ; 12$ ft., \$1.15; extra blades, $15 \mathrm{c}$ each.

\section{Duplex}

\section{See Cut No. 10}

A double-edged saw, with fine teeth on one side and coarse teeth on the other. Can also furnish this with teeth on one side only. Weight, 1 lls. Price, 75c.

\section{SEARIGHT PRUNING TOOLS}

This year we have taken up the line of Searight Pruning Tools, believing them to be the best line on the market. Not one single piece of casting of any description is used in making these pruners. All hooks, metal handles, etc., are forged from steel, which should be sufficient guarantee as to its quality. All other metal parts, not necessary to be made of forgings, are cold rolled sheet steel. They are not cheap, nor built for cheap trade. Cheapness and quality seldom go together, yet they are cheap when quality, service and satisfaction are considered. These tools, therefore, are produced and offered to the public at as low a price as class and quality will permit.

For Books on Pruning, Nursery and Fruits, see Page 74. 


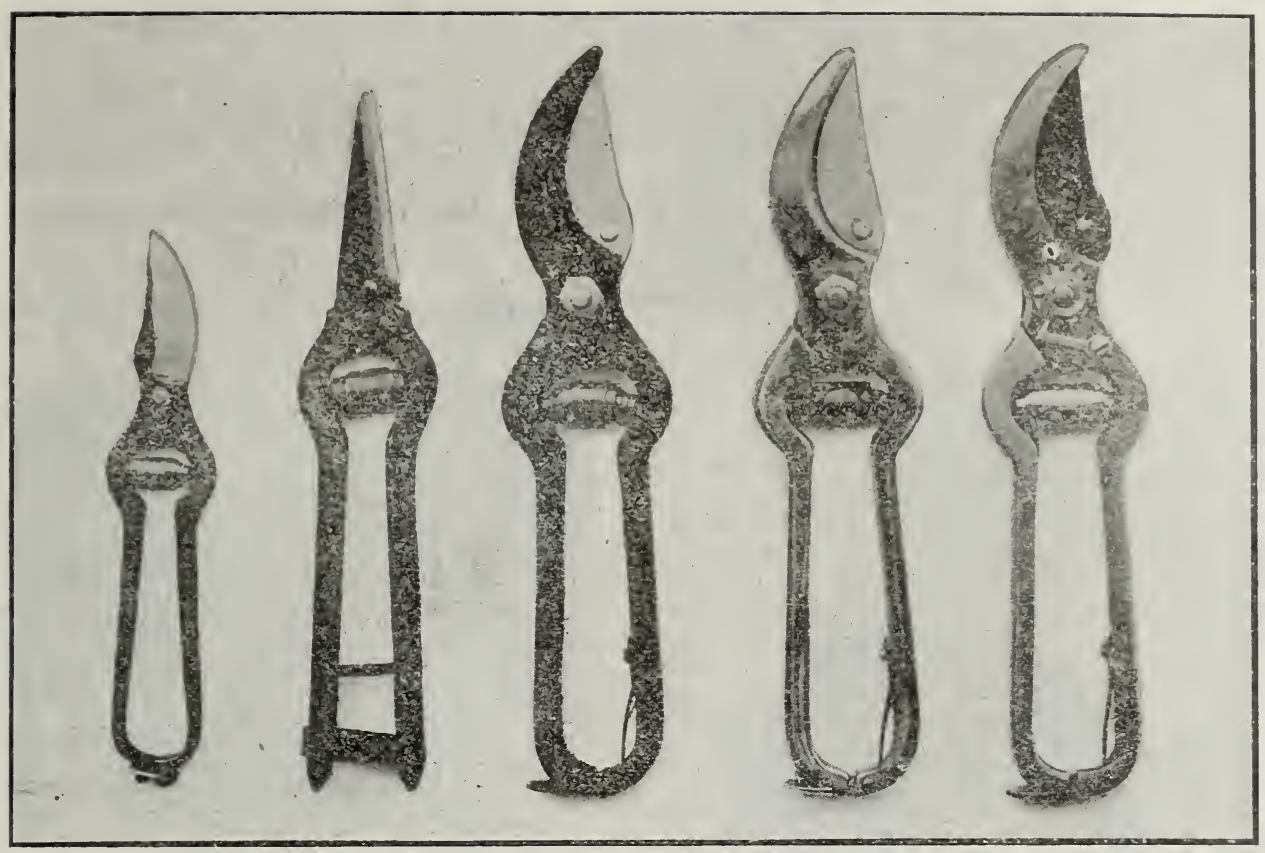

No. 1 No. 2 No. 3

No. Sos

No. 885

NOTE-Compare numbers or cut to those in description. No. 1 -Length $61 \frac{1}{2}$ inches, black handle, polished blade; fine for trimming roses or thinning fruit. Price, 30; postpaid, $40 c$.

No. 2-Length $7 \frac{1}{2}$ inches; an extra good tool for thinning fruit. Price, 35c; postpaid, 45c.

- No. 3-Length 9 inches; California patter'n, black finish, volute spring. Price, 50c; postpaid, 65c.

For Prices of Nos. 808 and 888, see page 54

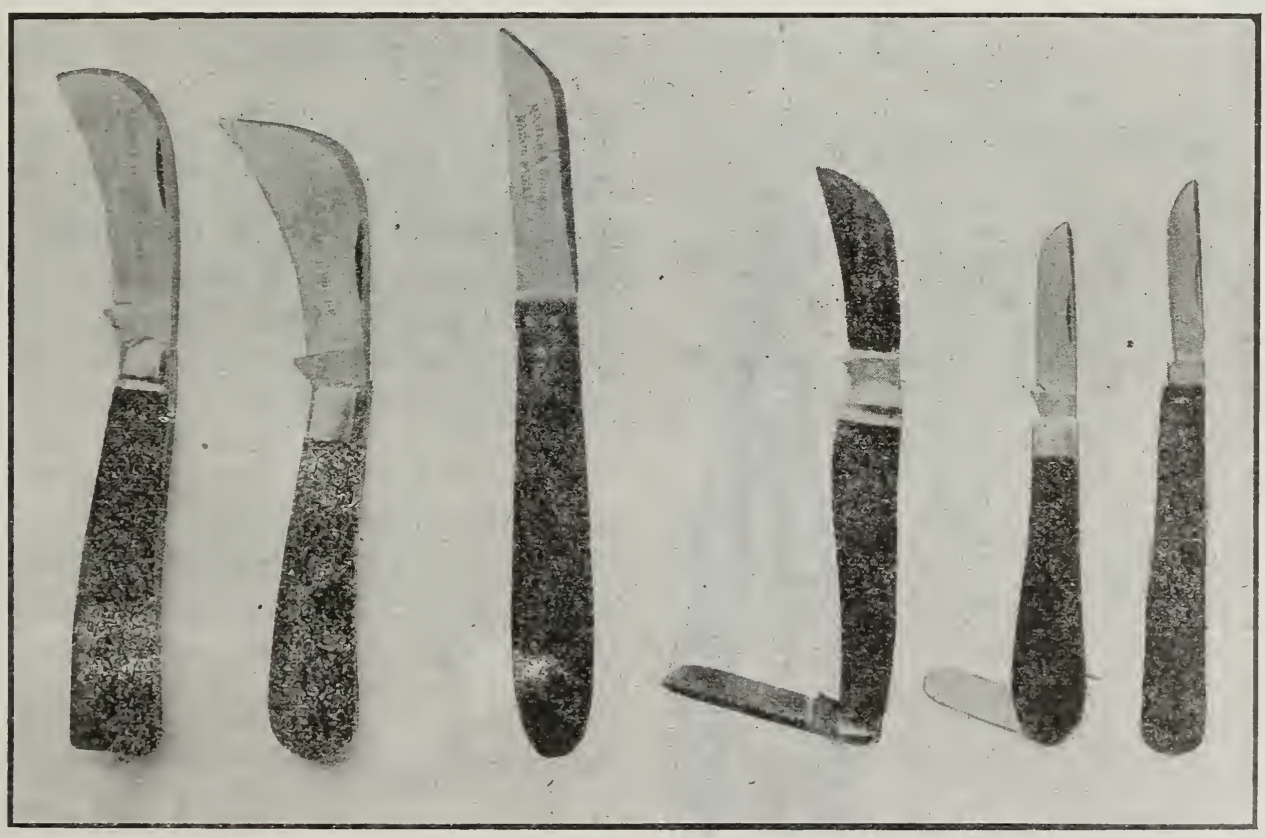

No. 6 No. 7

No. 8

No. 9

No. 10

No. 11

NOTE-See numbers in description.

Pruning Knives

No. 6-Polished wood handle. Price, \$1.00.

No. T-Plain wood handle. Price, 75c.

No. 9-Budding and pruning knife: horn handle, best steel blades. Price, \$1.00.

\section{Grafting Knives}

No. 8-Plain wood handle, stationary blade, razor of steel; made by Maher \& Grosh. Price, $40 \mathrm{c}$.

Budding Knives

No. 10-Ebony handle, ivory, bark opener. Price, $\$ 1.25$. nary bark opener, Price, $75 \mathrm{c}$ 
No. 1. Extension Tree Trimmer

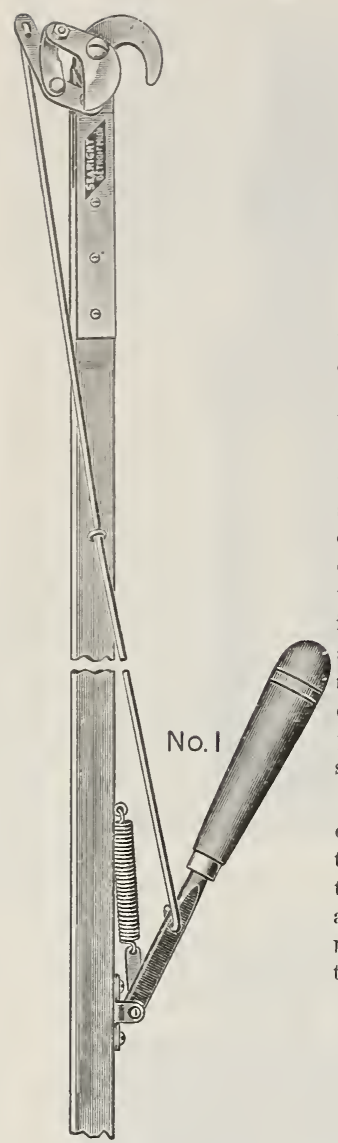
strain on the nole.

\section{No. 888. Plain Hand Pruner}

No. 1 has a compound lever head and is made with a hook and side lever. It is calculated for heavy work and will cut a limb up to $11 / 4$ inches in diameter. Instead of running the rod connecting the knife lever along one side the pole to a handle lever, we have placed the handle lever on the opposite side, which allows the rod to cross the pole. (We have a patent pending on this feature.) As a result one-half the sirain is thrown on one side of the pole and one-half on the other, which gives about double strength, and instead of the pole warping and bending, it has a tendency to remain straight and stiff. We recom. mend No. 1 trimmer in lengths exceeding 10 feet as the com. pound leverage relieves the

The strength, durability and easy cutting aualities of these trimmers will appeal to both the merchant who handles them, and the man who may have the pleasure to uset them. Each trimmer is fully warranted.
This pruner will be found second to mone in easy cutting qualities, material and workmanship. It is placed on the market to meet the wants of those who wish a thor. oughly good tool.

No. 80.S. Same as No. Ss.s but not polished. (For cut, see page 42 .)

\section{No. 18. Hand Pruning Saw}

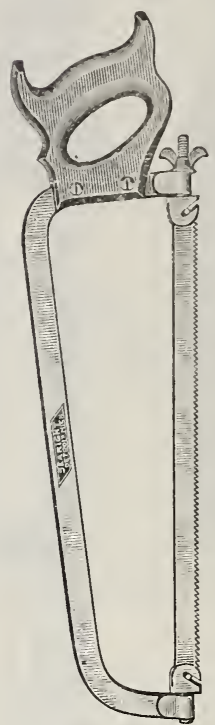

In nrder to make our line of pruners complete, we have added a bracket hand pruning saw, with a blade su arranged as to be turned instantly to any angle.

This type of saw is the most popular because it is light, is capable o being used at any angle with practically no danger of hreaking or buckling the saw. It will cut rapidly, make a clean cut with no danger of wounding the bark. This type of saw is becoming very popular wherever used. No orchard kit nf tools is complete without a saw of this type.

\section{PRICES OF SEARIGHT PRUNING TOOLS}

No. 1-Tree Pruner, 8-ft. poles...\$2.50

No. 1-Tree Pruner, 10 and 12 ft. poles

No. 888-Plain Hand Pruner, 9.

inch, \$1.60; postpaid.............. 1.85 No. 885-With Extra Blade, 9inch. $\$ 1.75 ;$ postpaid 2.00 No. sos-Hand Pruner, 9-inch, 1.00: postpaid ........................

No. 777-Two-Hand Pruner, 26inch handles inch handles

No. 18-Hand Pruning Saw

No. 18
1.25 200

2.75 1.35 1.75

\section{No. 777. Two-Hand Pruner}

Our No: 77 is designed on scien. tific principles and is the result of several months' study and experimental work.

Becausc of the fact that the majority of men are right handed, we have placed the blade on the opposite side from the general custom.

This permits the blade to be placed next to the body or main limb of the tree with the hook handle held in the left hand, while the rigit hand operates the blade. It may be readily seen with this arrangement that the hook remains stationary while the blade closes, instead of the blade being held stationary while the hook closes by twisting around the branch wounding the hark. It has other strong features, as follows:

The blade positively will not cut or dig into the hook. The blade will not push the branch from between it and the hook. By dropping the llook considerably below the center line we have produced a positive draw cut superior to any other. with an opening between blade and hook allowing a straight thrust at the branch.

No. 707 two-hand vruner is the same pattern as No. 777 , with shorter handles, but without the finish. Weight $41 / 2$ lbs.

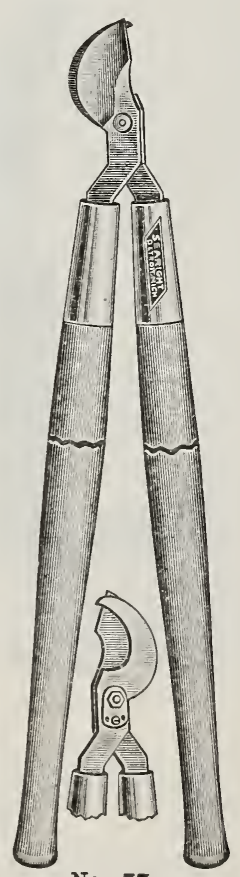

No. 77
Manufacturers tell us that owing to the advance on arsenic, it costs about $\$ 1.00$ per hundred pounds more to make. Arsenate of lead this year than last. We list it at practically the same price.

When you need a Spray Pump, write for our Pump Catalog, or call and let us show you one. We are agents for the Bean Spray Pump, one of the most Efficient, Economical and Satisfactory Spraying Outfits in the world. 


\section{Incubators and Brooders}

\section{We Are Authorized Agents for GENUINE STANDARD CYPHERS INCUBATORS Patented}

(Look for Trade Mark-Demand the Label)

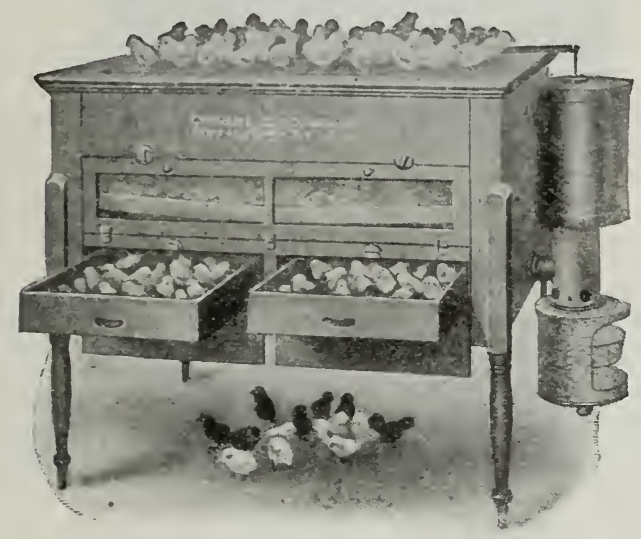

No. 3

Fire-Proofed, Insurable, Self-Ventilating, Self-Regulating, Non-Moisture, Efficient, Durable and Positively Guaranteed

Practical poultry raisers who mean business and desire the greatest possible success should look for and demand the qualities that have made Cyphers Incubators world famous.

To ow na Cyphers is to have an incubator that stands first, not onlv because it has affixed to it the fire insurance label granted by the National Board of Fire Underwriters and bears a world-wide reputation, but because of the well-established fact that it is the best hatcher of large, rigorous, livable chicks. It is positively guaranteed to outhatch any other make of incubator under widely varying conditions, season after season, and to last ten years without repairs.

For 1913- We offer our customers the Cyphers Company's complete line of incubators and brooders-the best on the market. For years the Cyphers Incubator has beeis consistently improved, always maintaining its leadership, until today it represents all that is most efficient, convenient and reliable in incubator construction.

The principles of construction that have made Cyphers Incubators "the world's standard hatchers" for the last twelve to fifteen years remain unchanged in the 1913 pattern. Their patented features, their entire freedom from the bothers, disappointments and losses common to the "cheap" or "bargain" incubator, make these high-class machines the best for you to own first, last and all the time. They are used with unequaled success in all parts of the civilized world, inder every practical condition hy men and women in all walks of life. They are money savers and money makers for poultry raisers who "meau business" - for men and women who want a real incubator with which to get out of poultry keeping all the profit and all the pleasure there is in it.

CYPHERS INCUBATORS have now been on the market fifteen years and today are used by more Government Experiment Stations, on more large, practical poultry plants, on more successful duck and ego farms and by a larger number of foremost poultry breeders than all other makes combined. For proof of these statements send to us for a copy of Crnhers Incubator Company's latest complete cata. logue-1913 edition-now ready for mailing, free on request. Book, $7 \frac{1}{2} \times 10$ inches.
EVERY STANDARD CYPHERS INCUBATOR IS GUARANTEED by the manufacturers to do first-class work in the harids of every purchaser who will give it a fair trial and we hereby place our guarantee back of theirs. In buying a Cyphers you take no chances. Persons who earnestly desire to succeed in the poultry business should have the right tools with which to work. Write us today for free illustrated catalogue telling all about these superior hatching machines.

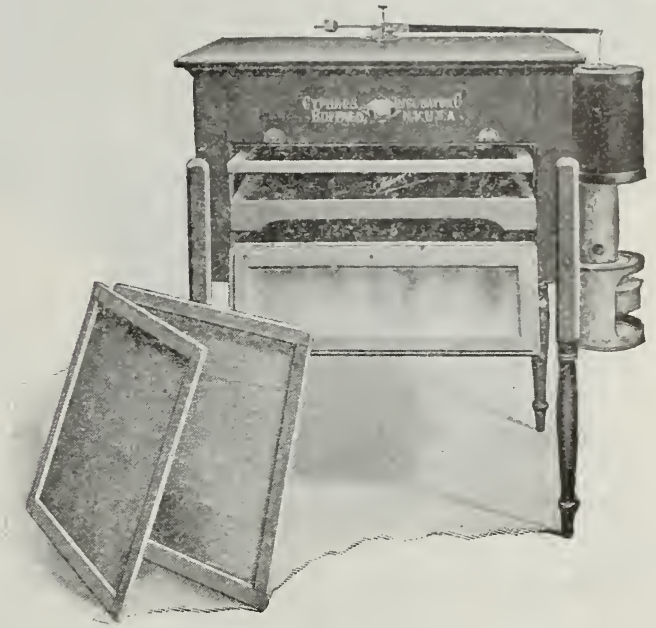

NO 1 STANDARD CYPHERS INCUBATOR, 1912 PATTERN-Fire-proofed, insurable, 14t-egg capacity. Showing "split" lower diaphragm removed egg tray and upper diaphragm partly drawn out. Price, \$25.00.

\section{SIZES AND PRICES OF CYPHERS FIRE-PROOFED INCUBATORS}

FREE ON BOARD CARS, SPOKANE, WASH.

No. 0 Holds 70 Henn Eggs..................................... $\$ 17$

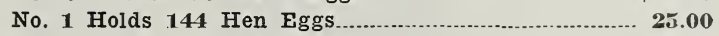

No. 2 Holds 244 Henn Eggs..................................... 35.00

No, 3 Holds 390 Hen Eggs

\section{Pedigree Egg Trays}

Pedigree Trays are in demand by poultry raisers who use trap nests of various kinds for special breeding vurposes; also by those who wish to keep in senarate lots, until properly toe-marked, the chicks hatched fram eggs of any variety of fowls obtained from different matings, or from different pens. They are a valuable aid to systematic, scientific poultry breeding. By their use the eggs placed in a No. 0 or No. 1 Standard Cyphers Incubator can be kept in four separate lots: also the chicks that hatch therefrom, and the eggs in a No. 2 or No. 3 Standard Cmhers can be kept in eight separate lots, also the chicks that hatch therefrom.

Price, each, No. 1 ................................ \$3.00

Price, each, No. 2

Price, each, No. 3......................... 35

\section{Demand This Label-Your Safety}

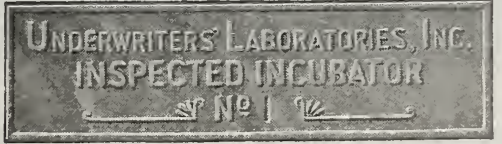

Form of Brass Label to be Found (in Serial Number) on Every Cyphers Brooder-All Sizes 


\section{STANDARD CYPHERS COIBINATION BROODFRS AND COLONY ROOSTING COOPS}

For 191:-Cynhers Unequaled Apartment Brooders anu Combination Roosting Coops have the same important ad. vantages over all other makes that are possessed by Cyphers Company 1912 incubators, in that they are fireproofed and insurable, havino the first fire insurance nspection label ever granted on a brooder.

Cyphers 1:19: Brooders, every size and style, are selfregulating, self ventilating and varmint proof. The out door styles are useable also as colony coops for the grow. ing chicks. They are easily and quickly converted into colony roosting coops by simply taking out the hover which is made rimovable for that purpose.

\section{Cyphers Style A Outdoor Brooder Fire-Proofed-Insurable}

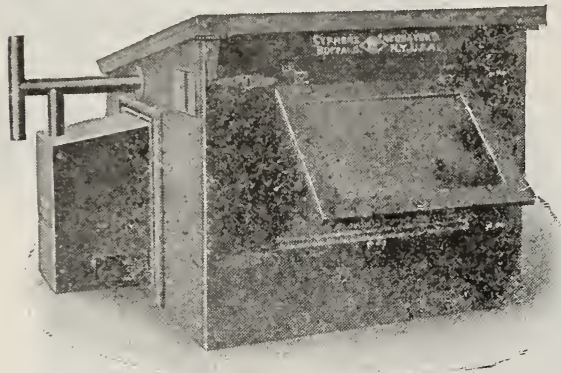

Two-Apartment, Combination Outdoor Brooder and Colony Roosting Coop, Self-Ventilating and SelfRegulating

This double use of the Cyphers Brooder means a considerable saving of money. It makes a safe and comrort able enclosure for the young chicks at night and saves the buying of a coop for them. These outdoor brooders, on account of their fire-proof construction, can be used in doors, although we supply a special brooder, Style D, for indoor purposes. All Cyphers 1913 Brooders, both outdoor and indoor, contain either two or three anartments. The popular Style B (shown in illustration herewith), contaus three apartments-first, roomy space under the hover second, hover chamber; third, well-lighted exercising apartment. It has often been said by users of the Cyphers Brooders that they mother the chicks better than a hen.

An important reason for this is found in the great practical advantage possessed by the entire line of Cyphers Brooders for 1913 in their self-regulatino feature. For years the self-regulator was attached only to the highes priced Cyphers Brooder (Style C), but it was so well received that now it is attached to all the Cyphers Company Brooders. It automatically regulates the heat in the brooder underneath the hover at all times, whereas in brooders without a regulator the heat has to be governed by a continuous watching of the lamp and turning the wick up or down whenever more or less heat is required.

\section{Style B Outdoor Brooder Fire-Proofed-Insurable}

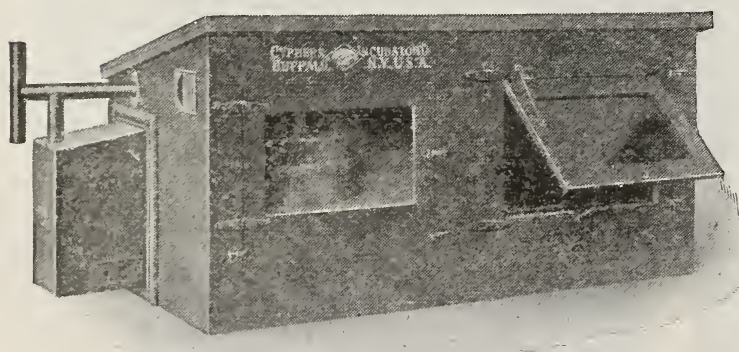

Three-Apartnient, Combination Outdoor Brooder and Colony Roosting Coop. Self-Ventilating and Self-Regulating.

Floors of Hover and Exercising Apartments on Same Level

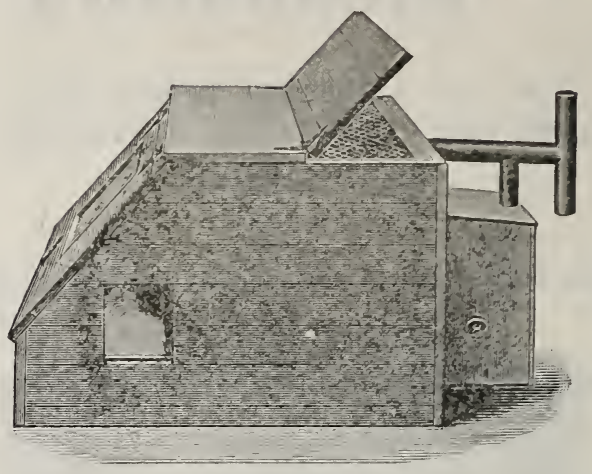

Style D

This brooder is practically the same in all respects as the Style A Outdoor type, except that the upper half is more convenient in shape and construction for indoor use. This brooder is for use in any kind of building where chicks may be kept, including rooms in dwellings, or suitable places in barns, sheds nr ordinary poultry houses. This brooder, being without an exercising apartment, should be used in rooms or enclosures in which the chicks can exercise freely during the daytime, or in poultry houses equipped with pens to be used by the chicks as runways.

\section{Cyphers New Portable Hovers}

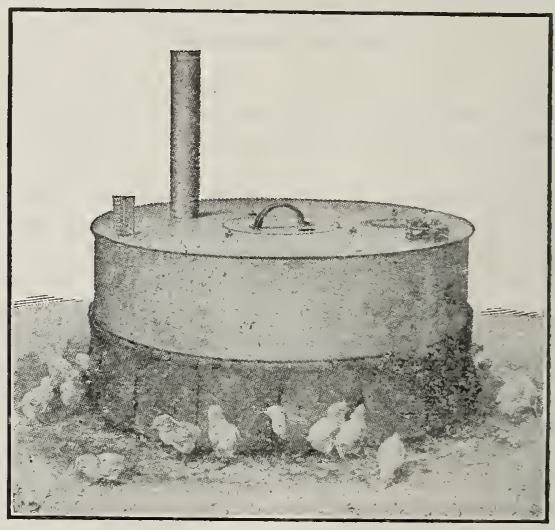

This Hover is self-regulating, self-ventilating, all-metal and indestructible. It is the latest improvement in portable Hovers. It is nositively and infallibly automatic in ventilation-a patented feature-the trapping of poisonous gases in a "dead air space" underneath the brooding Hover having been rendered absolutely impossible by the ingenious but simple construction.

Used without a brooder case, this Hoved will operate perfectly in any temperature above the freezing point and will do satisfactory work in a considerably lower tem. perature if the inmates are warmly bedded and protected from drafts, especially at night. With a brooder case and used indoors it will operate successfully in any temperature down to the zero mark, provided the chicks are wellcared for otherwise.

This Hover is for indoor use and has a rated capacity of seventy-fie newly hatched chicks, or of fifty chicks that are ten days to six weeks old. It will hover comfortahly one hundred newly hatched chicks, but we advise strongly a ainst trying to brood chicks in flocks greater than fifty to seventy-five- the smaller number preferred at all ages. Price, \$11.50.

For Poultry Books, see Page 74. 


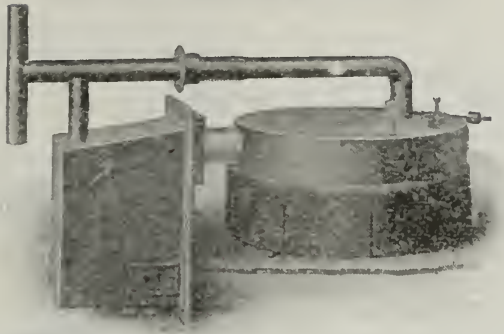

Self-Regulating and Bears Insurance Label as Separate Device

In addition to this unequaled line of brooders, we offer senarately the Cyphers Company's world's challenge Ataptable Hover. This machinerv-made, all-metal, guaranteed fire-proof heatine and brooding device is suitable to be used anywhere that heat is renuired for brooding chicks or ducklings. It can be used in a roosting coop, colony house, shed, hen house, barn or other building with or without any additional enclnenre for the chicks, or in a large goods case or organ or piano box.

Is pronounced by thousands of users to be the hest device thus far invented for heating home-made brooders. Reconimended especially for use in long brooding houses, one hover for each pen. Adantable hover is complete in itself, bears insurance label as a separate device, and is safe to use anywhere. Weight, boxed for shipment, only 40 pounds.

Complete Catalogue for 1913 contains fully illustrated desription of this self-regulating, fire-proof hover, also of the entire line of Crohers Apartment Brooders.

\section{SIZES AND PRICES OF CYPHERS ADAPTABLE HOVER AND COMBINATION BROODERS}

FREE ON BOARD CARS, SPOKANE. WASH.

Adaptable Hover, capacity $\mathbf{7 5}$ Chicks.

Strle A-Two-Apartment Outdoor Brooder, capacity

Style B-Three-Apartment Outdoor Brooder, ca-

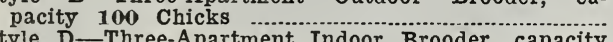

Stvle D-Three-Apartment Indoor Brooder, capacity

75 Chicks

16.00

21.00

15.00

\section{The Cycle Hatcher}

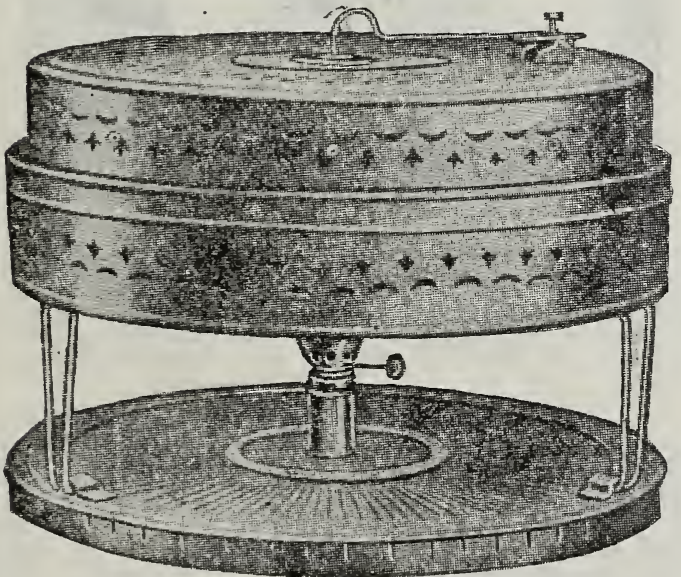

The Cycle Hatcher is designed to take the place of the hen and supply the wants of beginners in poultry raising or many that do not wish an expensive outfit. These ma. chines hold 50 eggs and are so constructed that the supply of heat comes from the center and is radiated in all directions like the rays of the sun, carrying with it an abundant supply of fresh, heated air, that is reauired to travel only six inches to reach every egg in the extreme portions of the nest. The heat is governed by a double wafer regulator that is placed so close to the eggs that it is sensitive to the natural heat of the growing embryo chick in the egg as well as the supplied heat from the lamp. The Cycle Hatcher is too simple in construction to require any long description of details, as the cut of the nest and complete machine show practically all there is to it. Price, complete, \$6.50.

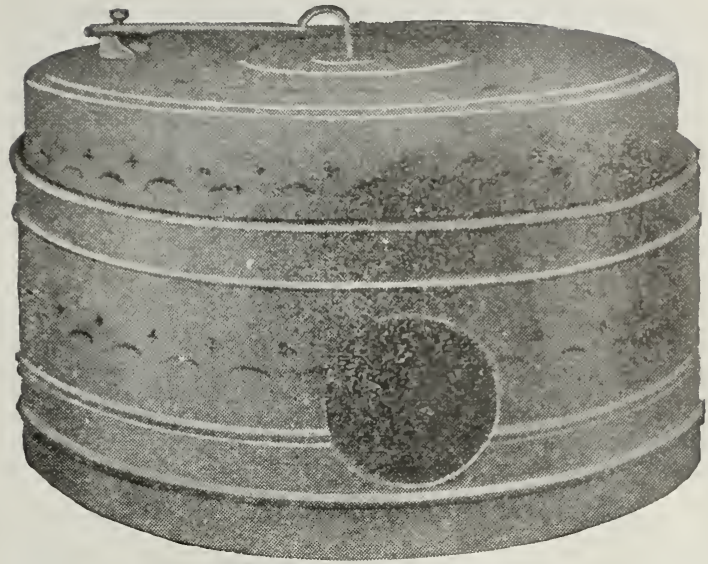

This combined Hatcher and Brooder is the result of many years' experiments to bring about desired conditions, making one lamp do double duty, and at the same time to have a machine constructed in a way to do successfully the work artificially, and at the same time to carry out the natural laws of incubation and brooding.

It is the machine that has made it possible to get such large returns from a few hens in the Philo System plant.

Just as good results may be had with this machine by setting a few eggs every day, once each week, or filling the machine half full of eggs and every ten days putting in a new supply. thus taking off a hatch every ten days or oftener, then filling in the empty portion of the machine with fresh eggs. Price, \$8.50.

\section{Electric Alarm and Lighting System}

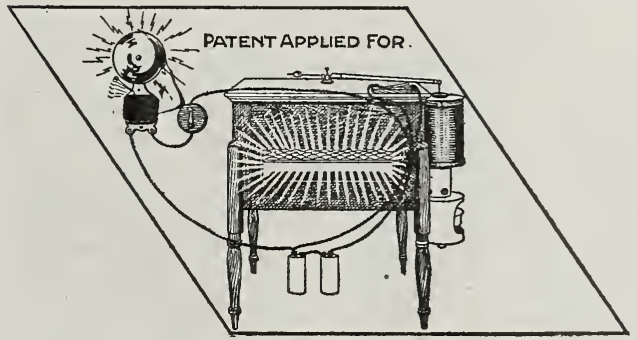

Mr. Incubator Operator:

Would you care to insure yourself against spoiled hatches during the life of your incubator for a fraction of the cost of one batch of eggs Would you enjoy going to bed at night with the peaceful assurance that you would not be allowed to sleep through such a calamity as a lamp going out or cmoking and exploding, probably burning down your house, or burning too high and literally cooking the egos or the emerging chicks Would you like to be able to read your incubator temperature and have the entire interior illuminated and be able to see everv egg and chick by the pressure of a finger on the edge of the machinè?

Until now these thin $r$ s have been impossible, but they are made not only possible but practical by the invention of the Alexander Electric Alarm and Lighting System.

These outfits may quicklv be installed in any standard box incubator by anyone who can read the directions and can use a screw-driver. No knowledge of electricity is required. The operation is so simple and nositive that a child can adjust it. A specially constructed thermostat is placed in the egg chamber and is adjusted and set so that an alarm bell rings when the temperature goes above or below any two desired points, for instance 98 and 105 degrees. If your lamp goes out you know it before the eggs are chilled. If the lamp burns too high or the regulator fails to work promptly or properly, your hatch can not be spoiled, for the hell will ring and continue to ring until you shut it off. Price of this outfit complete, with one bell, battery, tantalum lamn wire, switches, full directions, etc., \$3.S5. Weight, $71 /$, lbs. 
These brooders are round and lined with the best quality of water-proof, non-conductming material to retain the heat and make them easily cleaned. The cloth cover is attached to a wire frame and is adjustable to any height, that they may be easily raised as the chickens develop. There is a mattress or quilt three inches thick. filled with finely picked non-conducting material, a combination of wool and cotton, which makes the very best ouality of heat-retaining material for the lampless brooders. This quilt is laid on top of the adjustable cloth cover and retains the heat in a manner which has enabled us to raise chickens without lamps in a temperature below zero. Price, each, \$3.25.

\section{The Philo System}

The new book. The Philo System of Progressive Poultry Keeping, gives full particulars regarding wonderful discoveries with simple, $\epsilon$ asy-to-understand directions that are right to the point and fifteen pages of illustrations, showing all branches of the work from start to finish. Price, \$1.00.

\section{Common Sense Brooder Fixtures}

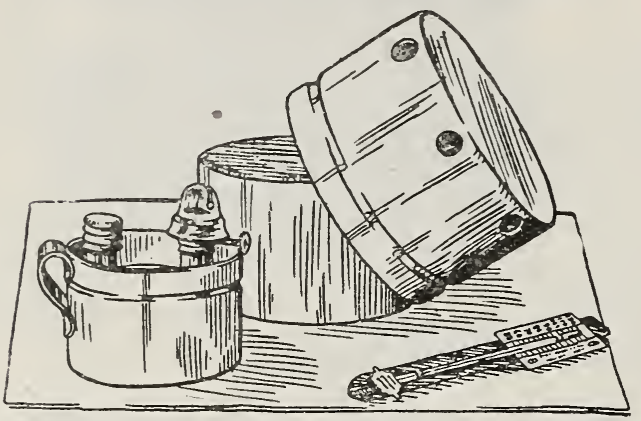

To those who wish to make their own brooders, we highly recommend the "Common Sense" fixtures. Hun. dreds of poultrv men are using them and some of them have 15 to 20 set. These fixtures include an upper and lower drum, Inland Safety Lamp and Thermometer. The construction of the brooder is simple and the air circulation perfect. For outdoor use the walls should be double and the roof inclined and covered with roofing.

MANNER OF CONSTRUCTION-First, nut in a tight floor $9 \frac{1}{2}$ inches from the bottom of brooder. Then mark and saw out size of large drum on this floor (using drum as pattern), 12 inches from center of side of brooder, to center of drum. Secure drum in place, then nail one-inch cleats two feet square under and around the drum, cutting out a two-inch hole from cleat and side of brooder to allow air circulation. Nail the lower drum up on these cleats. Bore sufficient holes through two sides of brooder, under this floor. to carry off fumes and furnish air for lamp. For the hover nail thin boards together, making it two feet square. Around this tack oilcloth wide enough to reach floor when hover rests on drum. Set the lamp under center of drum. Be sure and keep the receptacle on top of lamp always filled with water as this prevents overheating and explosion. Price, \$3.50.

\section{Regulators}

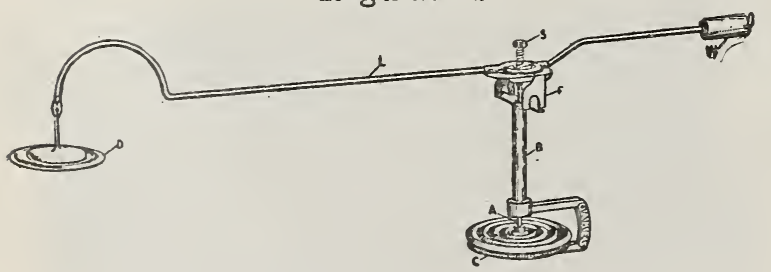

In this Regulator as shown by the illustration herewith, the wafer is inverted and as it expands it acts through the short lever beneath it on the connecting rod, and the down pull of the connecting rod so moves the top lever as to life the damper. Accurate adjustment is secured through the adjustment nut at the upper end of the connecting rod. This regulator is accurate and reliable anc will give good satisfaction. Weight, 12 oz. Price, \$1.50.
The Wafer Thermostat is made of two round concave dises, sealed together at the nuter edge. The cavity between them is filler with a volatile liquid which is very sensitive to changes in temperatire: PrAze, ipostpaid, 50c.

\section{X-Ray Egg Tester}

$\mathrm{X}$-Ray Egg Tester is made of the best block tin and consists of a central cylinder or lamp fhe. 5) $1 / 4$ inches high, with an outside diameter of $25 \%$ inches at the hase and $21 / 8$ inches at the top. It is designed for use on an ordinary hand lamp, fits over any style of burner with a diameter approximating that of the tester. In a dark room the lioht will be found strong enough to penetrate the shell and illuminate the interior of the egg. Price, 25c each: postpaid, 35c each.

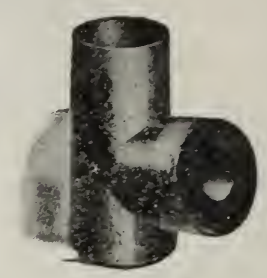

\section{Safety Brooder Lamp}

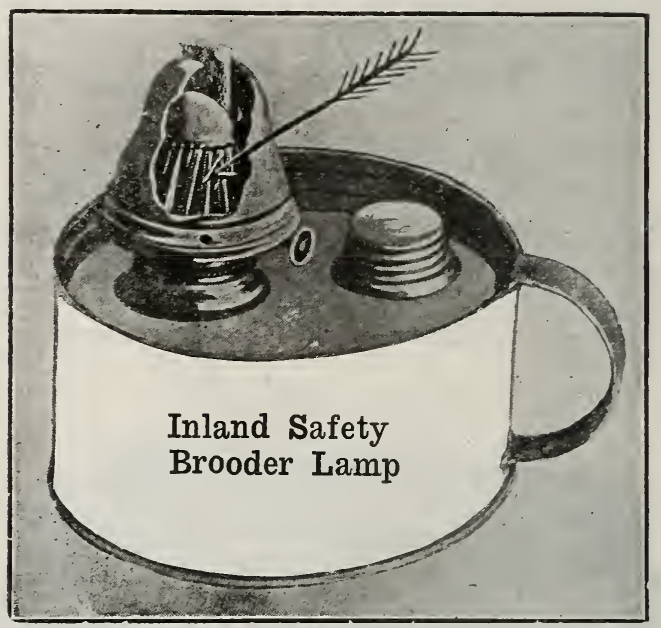

The latest and best lamp for the brooder: requires no chimney; never smokes, but burns a steady flame. The air fingers carry fresh air direct to the flame. This gives perfect combusion and more heat for a given amount of oil than with any other burner. A water chamber is on top of lamp to keep oil and burner cool, and prevent any chance of explosion. Weight, $13 / 4 \mathrm{lbs}$. Price, $\$ \mathbf{1 . 0 0}$.

\section{Lamps and Extras}

Large Lamp for Incubator and Brooder, Wt. 2 lbs...... st 3 ? Small Lamp for Incubator and Brooder, Wt. $13 / 4 \mathrm{lbs}$. 1 . No Chimney Burners with Collar

No. 1 Burners, postpaid

No. 2 Burners, postpaid

No. 3 Burners, postpaid

No. 1 Chimneys, postpaid

No. 2 Chimneys, postpaid

No. 3 Chimneys. postpaid

No. 1 Wicks, postpaid, per doz.

No. 2 Wicks, postpaid, per doz.

No. 3 Wicks, postpaid, per doz

\section{Eocene Oil}

The best oil for incubator or brooder. Prices vary. Write us and we will quote.

We take subscriptions for the Reliable Poultry Journal. Price, 50c per year. 
Mann's Green Bone Cutter

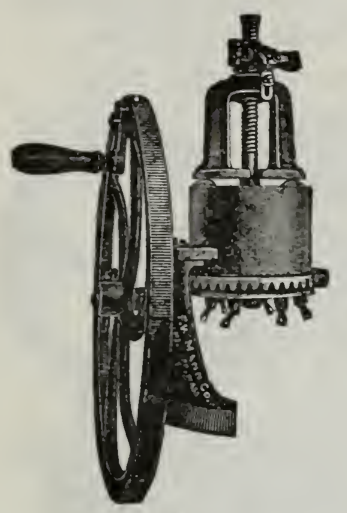

No. $5 \mathrm{~B}$
MANN'S NO. $\div \mathrm{B}-$ Has four knives, large cylinder, and has the latest patent (automatic, governing spring feed). which makes it one or the best. Price, \$10.*0.

NO. 5 B. M.-Mounted on iron stand, no expense to set it u Place for pan to catch the bone. Patented automatic governing spring feed. Cylinder, 6 inches diameter, 4 inches deen. Cutter plate has four knives instead of three. Will cut faster and easier $t$ li a $n$ other types costing twice as much. Weight. - pounds. Price, \$14.00.

MANN'S NO. - - The New No. 7 is mounted on strong iron stand, and has patent automatic governing spring feed. Large, open-hinged cylinder giving instant access to all working parts; has six knives, gear guard, anti-clog device, heary balance wheel and other improvements. (See cut.) Price, \$15.50.

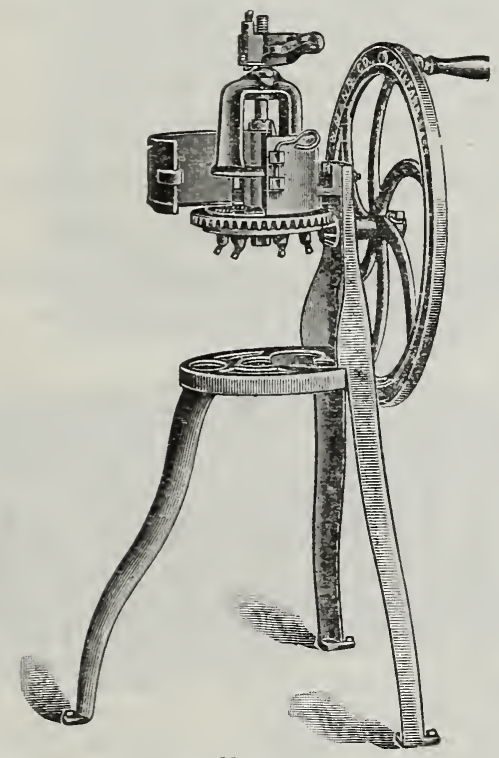

No. 7

MANN'S NO. $\mathbf{7}^{1 / 2}$-Adapted to run either by hand or by power, without any change. The particular advantaoe of the No. $71 / \mathrm{m}$ is that while it is a complete power machine, it can be operated by hand just as easily as the No. 7. Thus it is always ready for use. It is recommended even if you have no power at present, for should you get power in the near future, you need be at no further expense. Price, \$21.50.

\section{The Wilson Dry Bone Mill}

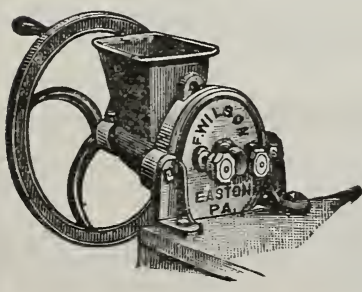

No. 1 is a practical mill, grinding all kinds of shells, crockery, grit, burnt or dry bone feed, etc. Instantly adiusted to grind coarse or fine. Weighs 33 pounds. Diameter of hand wheel, 20 inches. Price, \$5.00.

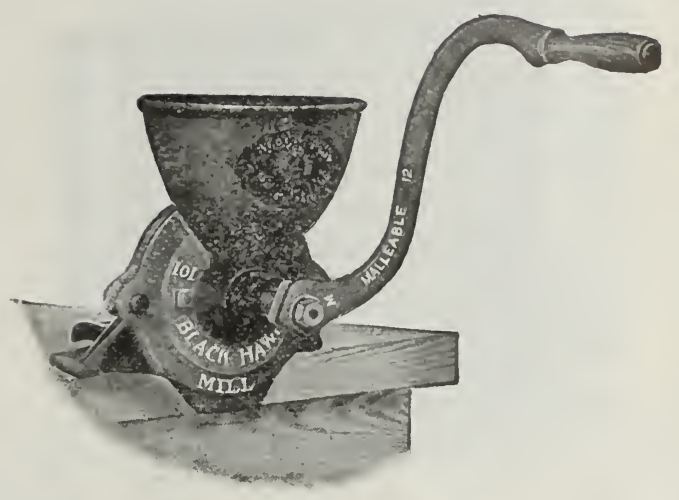

WITH A BLACK HAWK MILI in the house vou crack the corn or grind any kind of grain to whatever degree of fineness you desire or whichever will best suit the use or condition of rour chickens. Its wide range of usefulness, its durabilitv and small cost will appeal to the family in town with a small flock in the back yard, and it has a large enough capacity to meet the needs of those in the country who keep poultry on a big scale. Price, \$3.00.

\section{JOHNSON'S GRIT IMAHINE} (This IMachine Furnished the Grit for the A.-Y.-P. F'air, as well as Nearly All of the Northwest Poultry Shows)

The Johnson (former$1 y$ Bond) Grit Machine, easiest and best machine on the market; has compound leverage, and is very powerful. IV i l I break rock, limestone, ore, crockery, glass, dry clam and oyster shells. etc. No horse work about it. A boy of seven years can work it. IT is indispensable where fowls are yarded up, or for brooder chickens. Price, \$4.25.

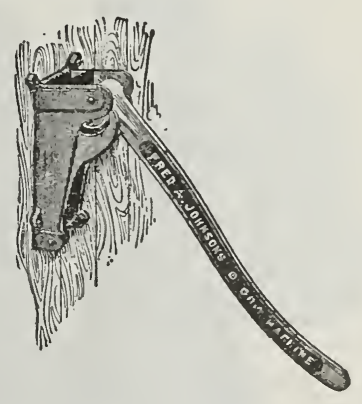

The Reliable Pedigree Nest Box

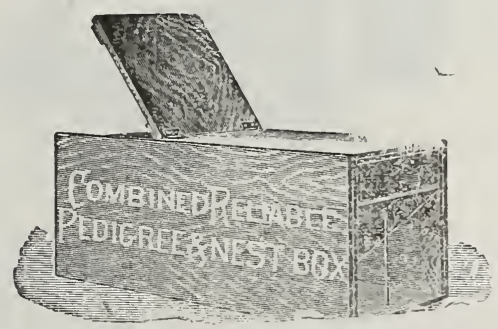

We illustrate herewith and offer for sale the Reliable Pedigree Nest Box. The best and most successful breeders in the country are at present following the pedigree plan and using automatic nest boxes of some kind. They can be used either for pedigreeing the stock or as an ordinary nest box. Price, $\$ 3.00$. 


\section{Reliable Grain and Oat Sprouter}

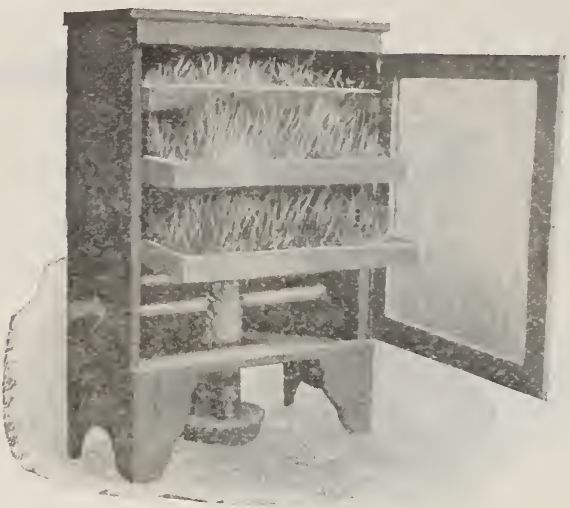

Photographic View of the Front

Poultry needs green food in one form or another, especially in the winter time. If the scientific experimenters had not proved this fact, we would still know it to be true simply by watching the fowl in its natural state. There is nothing that fowls eat with a keener relish than bugs, worms, grubs, and insects of various kinds, which they secure in the summer on their own accord.

You want the eggs when the eggs sell at the highest price. Green food makes your hens lay; they eat this green food because it is good for them. Nature demands it and if you want to get the best results from your fowls, you must follow nature's methods as nearly as possible. Price, $\$$ S.50.

\section{Banner Root Cutter No. 7}

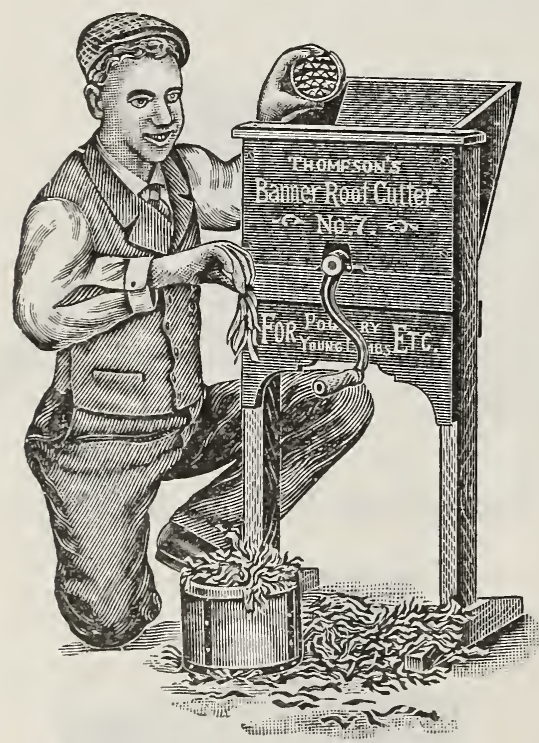

\section{Banner Root Cutters}

These excellent machines are so low in price that every farmer, stock raiser or poultrv man should have one, as roots are the cheapest green feed for stnck, and make healthy hens, their economy and food ralue is astonishing.

The Banner is substantially made of first class material, cuts fast, is easy running, leaving the food in fine ribbonlike strips, making choking impossible. Is eaten by fowls of any size, or bv lambs.

We offer two sizes: No. 7 (see cut). Weight, 50 pounds, $\$ 5.50$.

No. 2s, a larger cutter with pulley for attaching power; can also be run by hand. Weight, 150 pounds, \$21.50
"New Model" Clover Cutter for Poultry Removable Steel Knives-Adjustable Cutter Bar-Runs Easy-Cuts Fine-Is Durable

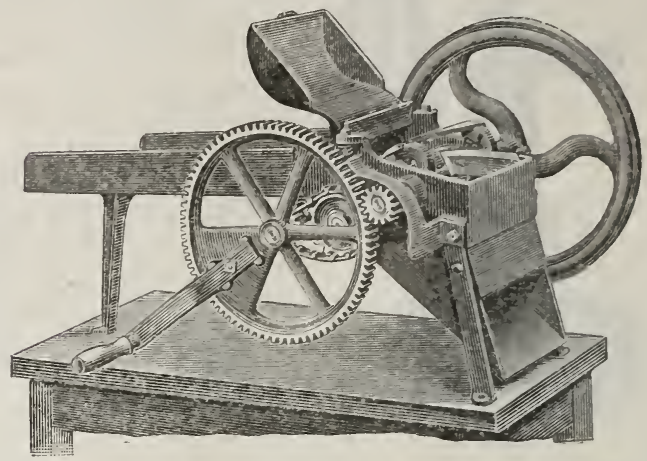

The e"New Model" (lover Cutter is designed for cutting either green or dry, such growths as clover, alfalft, reoetable tops, etc., into $1 / 8$-inch lengths. These growths are the cheanest and most productive egg-forming poultry foods for cold weather.

The "New Model" is made only of iron and steel, from entirely new patterns. It is a strong feeder, has large capacity, runs unusually easy and will in perfect work indefinitely. Length over all, $281 / 2$ inches.

The machine is intended to be mounted on a box or bench at any height to suit the operator.

Price, with four 7 -inch knives............................ S1n $-\mathrm{n}$ Price, with extended shaft and pulley for power........ 13.00

\section{SITES' VENTILATED COOP}

\section{For Shipping Live Poultry}

The Best, Cheapest, Strongest, Lightest and Most Durable Coop in Use

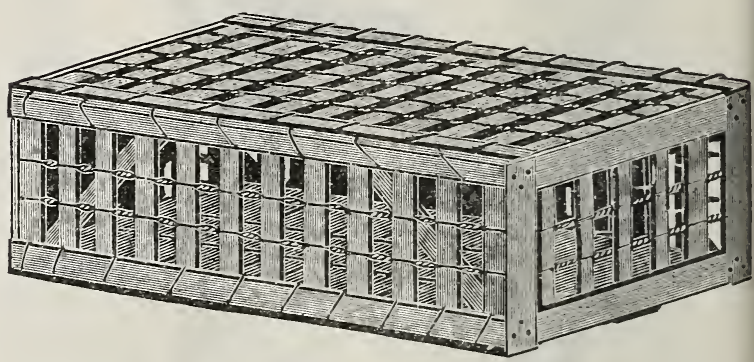

Our latest improved Coops are far superior to any heretofore made having substantial frame ends and thoroughly braced which adds additional strength, durability, firmness and prevents swaying or sagging.

The door on top of Coop is securely held in place by a steel spring which forms a hinge for the door. It cannot become detached from the Coop and is always in place.

Owing to thorough ventilation poultry is prevented from smothering. Shippers using our Coop (owing to lightness) save in express charges alone from 50 to 75 per cent. The Coop is easily handled and convenient for loading and transportation. Poultry will show to better advantage owing to neatness and beauty of Coop. We carry in stock the following sizes:

Chicken Coops, standard size, 3 feet long, 2 feet wide and 1 foot high, \$2.00.

Chicken Coops, special size, $\mathbf{3}$ feet $\mathbf{S}$ inches long, $\mathbf{2}$ feet 3 inches wide and 1 foot high, $\$ 2.25$.

\section{Inland Shipping Coops}

All wood, neat, very light, but strong. Poultry raisers selling poultry at fancy prices should always use these coops.

No, 1-10x21x18, 35c; 6 for

$\$ 1.50$

No. $2-10 \times 24 \times 20,45 c ; 6$ for

2.25

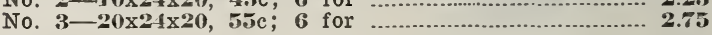




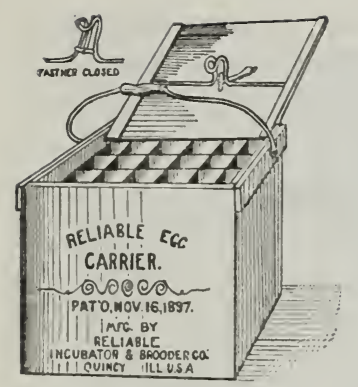

Reliable Egg Carrier

Nicely painted; equipped with the very best fillers. Patent top and sling handle. Holds twelve dozen. (See cilt.) Weight, 81/2 lbs.

Price, each $75 \mathrm{c}$.

\section{The Defiance Egg Carrier}

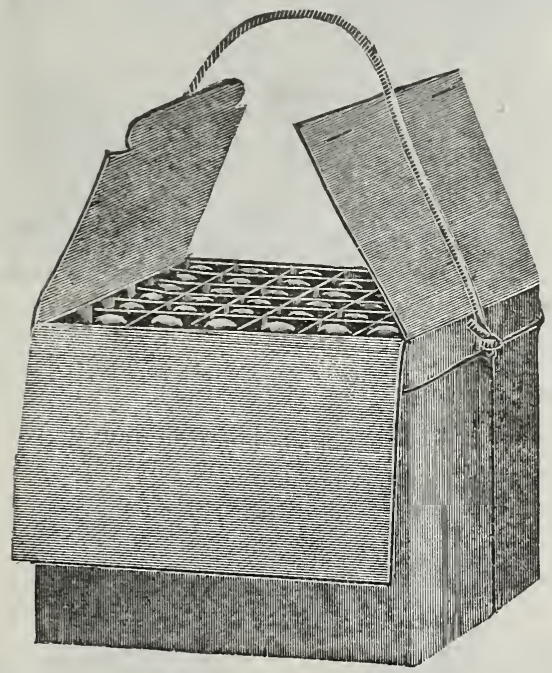

Holds 12 dozen eggs. It consists of one piece of heavy card board, and when set up ready for use is 12 inches long, 12 inches wide and $9 \frac{1 / 2}{2}$ inches high, weight, including fillers and division boards, 6 lbs. Price, each, 35c.

\section{Paper Egg Boxes}

Intended for $\mathrm{u}$ s e in delivering egos to private families. If you have a select egg trade vou should use this box. They ship knocked down at a low rate. One doz. 15c; ver 125. \$1.25: per 500. \$4.25; per 1000. $\$ S .00$.

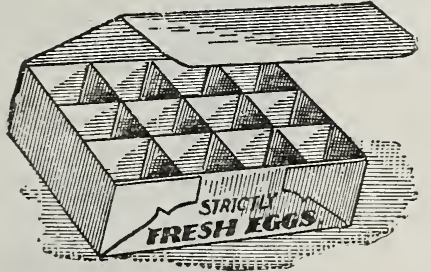

\section{Shipping Boxes for Day-Old Chicks}

These Shipping Boxes are well made of high-test corrugated paper, which is very strong and durable, and ret is so light in weight as to reduce express charges to the minimum-a feature that will be appreciated by our cus tomers. The construction of these hoxes is such as to afford the greatest strength and stiffness, without unnecessary bulk or weight. They are shipped in " knock down" form to take lowest freight and express rates, and are constructed in such a way as to be easily and rapidly assembled.

25. Chick size, 20c each; dozen

-Chick size,

Weight, per dozen boxes: 25 -chick size, $10 \mathrm{lbs}$.

\section{Egg Cases}

30-dozen case, with pasteboard fillers

Pasteboard fillers for $\mathbf{3 0}$-dozen case

Pasteloard fillers, per case (for 12 30-doz. cases)....... 1.80

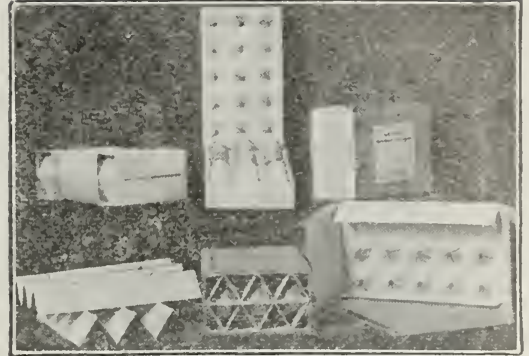

The Diamond Egg Carrier is something entirely new and in a class br itself. We can ship them in the flat and thereby save a large amount on freight. The peculiar construction of the box in $V$-shaped wedges enables us to make it of very light material while still retaining great strength. The construction is simplicity itself. A child can put them toorether and pack the egos. There is no dust, no litter and they are always ready. Eggs can be shipped on a moment's notice. The eggs do not come in contact with the outer box at all, having cushion on all sides and when wrapped in tissue paper. which always accompanies each package, there is absolutelv no jar, this insuring safe transportation to a customer, Eggs can not be taken out or substituted without detection, as we use a gummed label paper to seal the box with.

Made in 15, 30 and 25-ego sizes. For 50, 75 and 100 eggs use 2,3 or 4 of the 25 -egg size. With each rackage and enclosed therein are full directions for setting un gummed address labels, tissue paper with which to wrap the eggs and gummed paper with which to seal the box.

Price, 15-egg size, $15 \mathrm{c}$ each, 6 for $75 \mathrm{c}$; dozen ….......\$1.40 Price, 30-egg size, 25c each, 6 for $\$ 1.25$; dozen........ 22.5

Price, 25-egg size, 20c each; 6 for 1.10; dozen........ 2.00

Price, 15-egg size, duck, goose or turkey, dozen........... 1.50

\section{Drinking Fountains}

The Galvanized Iron Drinking Fountains embody every good feature of a down-to-date drinking fountain, and are believed to be the best in use. They have done much to supplant the old-style earthenware fountains which could not be thoroughly cleaned and purified. A fountain that cannot be easily and readily cleaned out, and in which water soon hecomes sour, is highly objection. able. A fountain that will burst if the water in it freezes is also an annoyance and a source of loss. These fountains are easily filled, easily cleaned and kept clean. Prices: 1 qt., 25c; $1 / 2$ gal., 35c; 1 gal., 50c.

\section{Inland Feed and Shell Box}

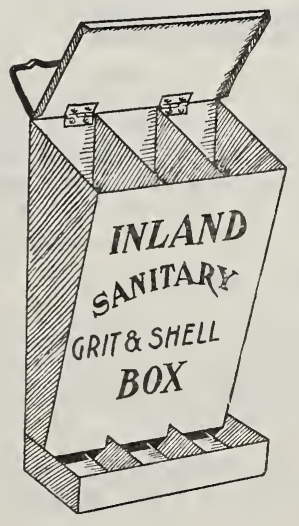

A Necessity in Every Well Plant

The Inland Sunitary Feed and Shell Boxes work a material saving in grit, oyster shell, ground bone, charcoal or poultry foods. They are thoroughly practical, self-feeding boxes, well made out of heavy galvanized iron. It is provided with a cover or lid. which protects the contents and being placed at an angle furnishes a slanting top, preventing the fowis from roosting on the top of the box. It is also provided with a strong handle by which it may be hung to the wall of the poultry building. Price, two compartment, 65c; three compartment, $75 \mathrm{c}$, weight $\mathbf{3}$ lbs. Price, four compartment, S5c. weight $4 \mathrm{lbs}$. 
The Inland Poultry Fount

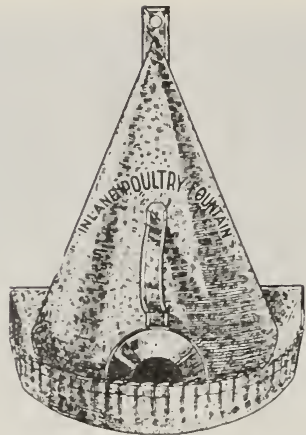

These fountains are something new and extra serviceable in the way of Poultry Fountains, and we feel that in in. troducing them that we have the best fount placed upon the market. The back is flattened so that it can be hung on the wall or against an upright post or board at any height. As the bottom is also flat, it can be set upon the ground or on a raised board. One extra good feature in this fount is that it will accommodate 6 to 12 fowls at once, where others only accommodate one or two. They are made of galvanized iron, and with proper care will last many years. Made in two sizes. 1 gal., $75 \mathrm{c} ; \mathbf{2}^{1 / 2}$ gals., $\$ 1.00$.

\section{Automatic Fountain and Feeder}

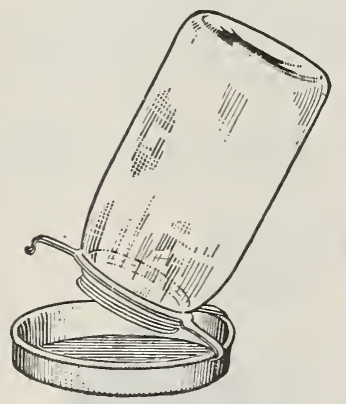

Feeds water, grain, grit, etc., automatically. Is easy to fill and onerate. Just lift trigger, as shown in cut, which releases pan, clip remaining on jar, leaving pan without any obstruction, atording easy cleaning. Thus a sanitary fountain.

Made to fit any half gallon, quart or pint

Mason jar,

We do not fur-

nish jars.

Price, 2.ic postpaid, express or freight; each, 15c;

doz., \$1.25.

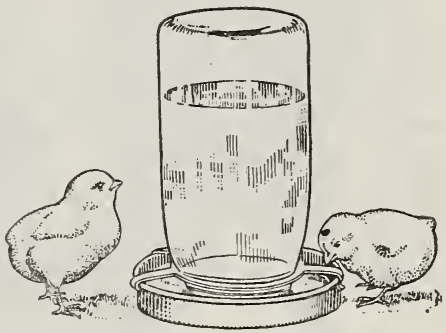

\section{Champion Leg Band}

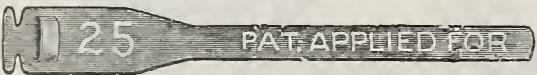

The oldest and most popular band on the market. This band is made in one piece in two sizes, adjustable to fit any fowl. They will stay where you put them. Held by double lock, it is impossible for them to lose off. Made of aluminum or copper in two-sizes, large size for Asiatic class and turkeys: small size for Plymouth Rocks and all smaller breeds. Price (postpaid), 12, 15c; 25, 30c; 50, $50 \mathrm{c} ; 100,80 \mathrm{c}$

\section{Aluminum Pigeon Bands}

Pigeon Bands are seamless and open, with number.

\section{PRICE, POSTPAID}

Seamless, 12, 30c; 25, (30c; 50, \$1.00; 100, \$2.00. Open, 12, 20c; 25, 35c; 50, 60c; 100, \$1.00.

When buying your feeds, remember there are none better than the Clover Leaf Brand.
Acme Spring Lever Poultry Punch

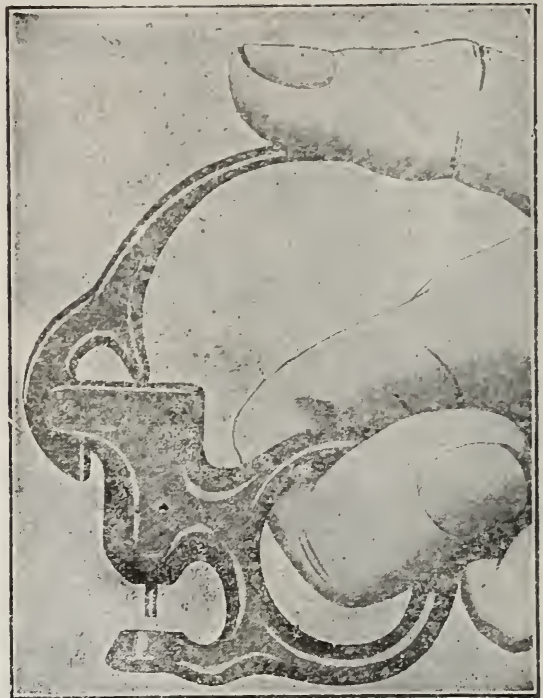

If you keep a record of your chicks, of the different breeds, hatches, strains, etc., there is no better, quicker or easier way than by using our latest invention, the Acme Spring Lever Poultry Punch for making the web between the toes. Price, 35c postpaid.

\section{Petty's Poultry Punch}

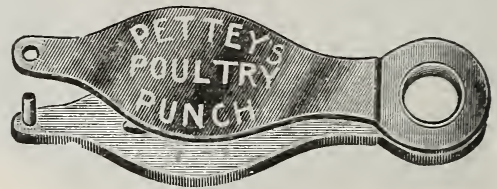

Latest, most convenient Poultry Punch; can be put on a key ring or used for a watch charm. Will not clog. Thoroughly practical. Price, postpaid, 25c.

\section{Wire Nests}

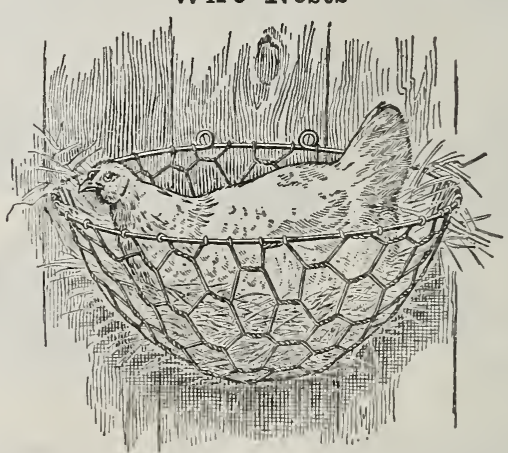

Plain Nests. These nests are strongly made from heavy japanned steel wire and will last a lifetime. They are in. tended to be fastened to the wall with screws or screw hooks. There is no room on them for lodgment of lice or vermin of any kind: they are easy to keep clean and are far superior to wooden boxes. Price, each, 20c; per dozen, \$1.50. Weight, each, $12 \mathrm{oz}$.

\section{Lime Nest Eggs}

The popularity of the Lime Nest Egg lias spread across the country like a great storm wave sweeping the continent. Not only the poultry fancier, but the every-day farmer appreciates its merits and superiority-orer the ordinary porcelain nest eggs.

They look more like a real egg. Its composition is a natural nest disinfectant. The porcelain ego becomes so cold in winter that a hen will not sit unon it but scratch it out of the nest. Lime is a non-conductor of heat and cold and does not become near so cold. It is never scratched out of a nest. Mrs. Hen likes it. Price, 3 for 10c, 12 for 30c; postpaid, 55c. 


\section{Medicinal Nest Eggs}

The great discovery for ridding poultry of vermin. The least trouble to use of any remedy on the market Only place the eggs in the nests. They do the work.

Iedicated Nest Eggs should be used the year around, as in winter when they are all on the fowls is the best time to destroy lice. Our Nest Eggs will kill or drive them off to perish $i$ in cold. The poultry will then be in goos condition to start in the spring.

Directions for UseDon't expect one egg to rid your poultry and

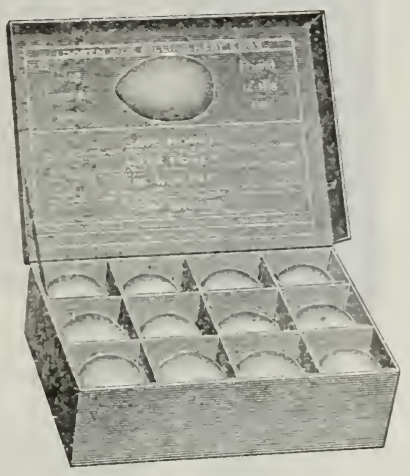
poultry house of lice. To

realize the best results keep an egg in each nest for laying hens; in each coop for brooding hens and chicks, and enough to change about under setting hens. Place one egg in each nest in which the hens are laving nad leave it there. Do not leave the eggs under setting hens more than one day at a time, unless put under the straw in the llest. Price, each, Jc; doz., 50c; postpaid, S5c.

\section{High-Grade Thermometers}

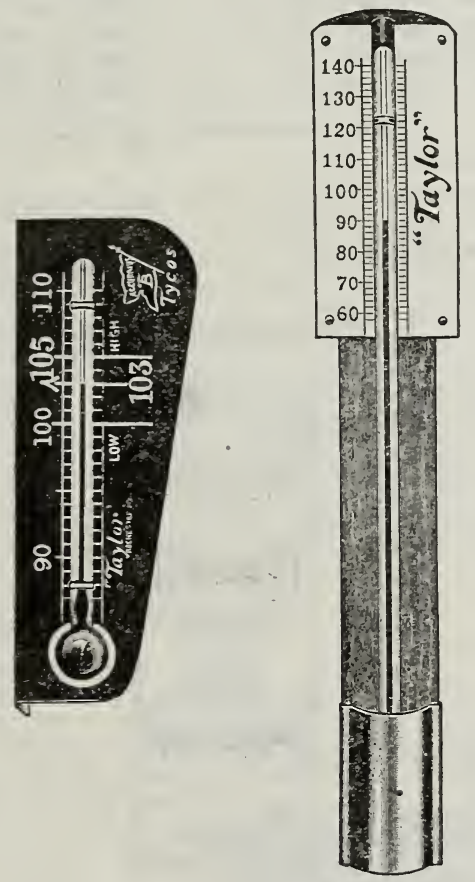

The best incubators and brooders manufactured are worthless unless the thermometers therein are correct. The thermometers here listed are guaranteed by the manufacturers to be thoroughly and expertly tested before they are offered to the public. Price, Incubator Thermometers, 75c postpaid. (Hang it from the top of egg chamber so it touches the eggs.) Brooder Thermometers, 60c postpaid.

\section{"Tycos" Certified Incubator Thermometer}

With scale etched on the glass tube, so that should the tube from any cause work loose on the mounting, the efficiency of the thermometer would not in any manner be diminished. Made in mercury tubes only. Each, \$1.25.

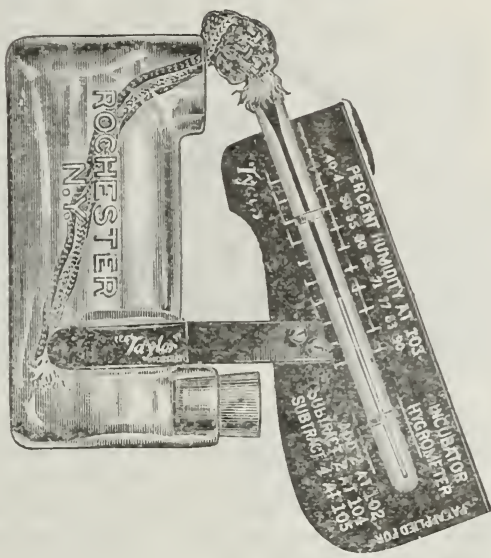

Millions of chicks die in the shell every year for the want of proper moisture conditions. The "Tycos" In. cubator Hygrometer is not a regulator of moisture, but is an indicator of conditions, so that if not correct, they may be made so. Price, $\$ 1.50$ each.

\section{The "Triumph" Caponizing Set}

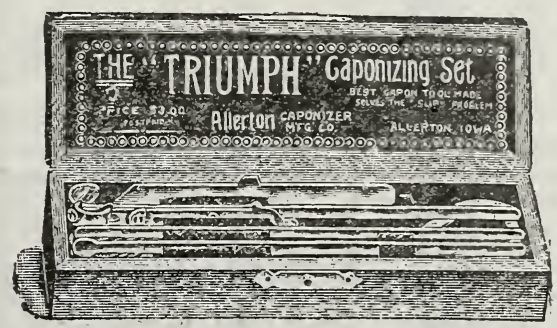

There is no doubt in the minds of up-to-date poultrymen as to the advantages of caponizing. The operation is very simple, and with a "Triumph Caponizing Set" any boy twelve years of age. can perform it with safety and thoroughness. Capons, as anyone knows, sell on the market as a rule from 5 to 8 cents per pound hicher than any other chickens. The demand for capons is always good, is steadily growing, and at this time a better market is assured the producer in this field than any other. Now is the time to get into the caponizing business, and the first thing to start right is to buy a "Triumph Caponizing Set." No more efficient, simple or more easily operated set is being offered the craft today than the Triumnh, and you will make no mistake by selecting the Triumnh set.

\section{PRICES}

Set in plush-lined, cloth-covered case. $\$ 3.00$

Set in polished hardwood box.

2.75

Set in japanned wood box

2.50

If you do not see what you want, write us. If we cannot furnish it, possibly we can direct you where to procure it. 


\section{Clover Leaf Chick Food}

The experience of poultry raisers is the same the world over. Everybody knows th a the first few weeks is $w h$ e $n$ the distressing losses come-losses that are so severe that about one-half of the people who engage in poultry raising are driven out ol the business, the weak unused stomachs of newly hatched chicks cannot suddenly accustom them selve to the illy adapt. ed poorly balanced foods that are supplied. Unbalanced food means failure of digestion, and that means decrease of an already low tempera. ture, chills, bowel troubles, "sleepy disease", and almost certain death. $\mathrm{By}$ using Clover Leaf Chick Feed you can give the chicks just what nature intended they should have, a food composed of grains (cracked), small seeds, grit, bone, dried sweet meat (to take the place of insects and bugs), charcoal, etc., etc., mixed in the right proportion to produce a quick and profitable growth without loss. You can raise so many more chicks by feeding it, that it is the cheapest food you can buy. Price, 6 lbs., 25c; 25 lbs., 80c; 50 lbs., \$1.50; can buy. Price,

\section{Clover Leaf Forcing Food}

Clover Leaf Forcing Feed, as its name implies, is a special focd intended for properly maturing young chicks after they are ready to be weaned from Chick Food, and to carry them along to the when it is desirable to place before them the larger whole grains. When the chicks are from six to eight weeks old they are able to eat larger particles of grain than are found in our Chick Food.

Our Forcing Feed contains a variety of grain in sizes and quantities exactly suited to the purpose for which it is intended. When used, its alue will be quickly made manifest in the improved appearance of the flock. It insures uniform and even growth with normal, healthy feathering. By the use of this food a strong, hardy chick is produced with more rapid growth than it is possible to attain in any other way. Price, 50 lbs., \$1.35; 100 lbs., \$2.50.

\section{Clover Leaf Balanced Ration}

This is a complete food ground and ready to mix with water, hot or cold, according to he season. It contains all the ingredients necessary to promote quick growth, to produce eggs and to keep the birds in a good condition, summer and winter. Random a n d haphazard feeding is no longer profitable. ' $\mathrm{i} \mathbf{r y}$ this food and be convinced. We have thoroughly studied the subject of food for fowls and know this mash will give you the desired results. It is no more trouble to feed than a bucket of ordinarv food which is often as good as wasted, as the results are not generally satisfactory. To be successful you should make

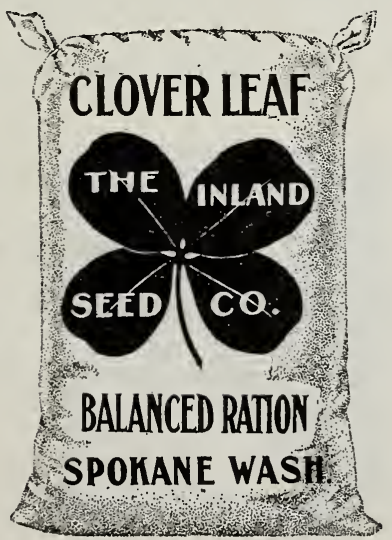

every pound of feed show results. Clover Leaf Balanced Ration costs only a little more than wheat or corn and is of twice the value. Try it. Price, 80-1b. sack, $\$ \mathbf{1 . 5 0}$.
Clover Leaf Scratch Food

This is a balanced ration, all grain poultry food, composed of the choicest grain and other ingredients. In the first place, our factory is sit uated where we can get the best of northerngrown wheat; to this is added sunflower, c or $\mathrm{n}$, oats, peas. kaffir. rape millet, oyster shells and grit in just the proportion that several years of experience has demonstrated is right. Every practical poultry man will readily concede that such a diversity of the most valuable feeds will put hens in just the ight shape for laying. Price, per 100 lbs.

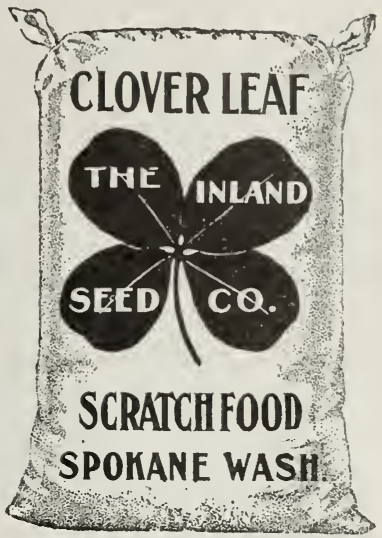

\section{Armour's Beef Scraps}

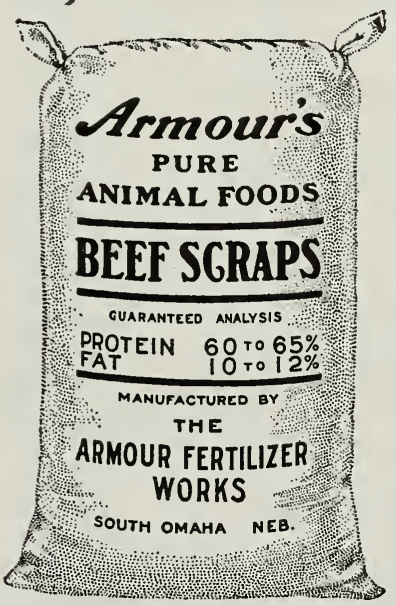

The object in buying Beet Scraps or Meat erest amoun gestible protein possible. as protein is what you are in quest of to balance your ordinary farm foods and grains. Armour's Beef Scraps contain from 55 to 65 per cent of protein, 10 to 12 per cent of fat and less than 5 per cent of ash.

The guarantee on protein gives you an approximate value of the feed, but the percentage of ash contained tells you whether $\bullet$ you are buying pure meat product or not. Price, 5 lbs. $25 c ; 100$ lbs., \$3.50.

Armour's Granulated Blood-One great reason why hens do not lay in are not supplied the proper elements to produce the yol of an egg. This can be remedied by the use of Dried Blood or Beef Scraps. Blood is the highest concentrated form of animal food and prepared so as to include all the elements of the so-called Red Albumen. Use on tablespoonful to six hens once a day. Price, $4 \mathrm{lbs}$., 25c: 100 lbs., \$5.00.

BLOOD MEAL (Standard), 100 lbs., \$3.00.

\section{Armour's Meat Meal}

Armour's Meat Meal contains from 50 to 65 per cen of protein, 10 to 12 per cent of fat and less than 5 per cent of ash. Made from hearts, livers, meat scraps and cracklings from United States government inspected animals. Pure, clean, sweet and wholesume. Will keep in definitely if stored in a dry place. Price, 5 lbs., 25c; 100 lbs., \$3.50.

\section{Alfalfa Meal}

The value of some green food for fowls can hardly be overestimated. For a winter food we have found by experience that alfalfa is one of the best for this purpose. It contains more protein, lime and mineral salts in soluble and digestive form than clover, and fowls relish it in either a green or dry state. For producing eggs in winter it has no equal. For little chicks it furnishes the element for growth, making bone, blood, muscle, feather and preventing disease. Price, 100 lbs., \$1.50. 
The sharpest and hardest grit known. Free from dust, is sharp, hard and clean. Rich in iron, sili c a, aluminum and mica, a health giving tonic. Viewed u n d e r the magnifying glass, it shows myriads of crystals clear as glass and sharp as a diamond. Each crystal has sharp edges, which cut and grind, and grind and cut until the last minute particle is worn away. Thus it will. last two or three times longer than any other grit, and is therefore cheaper. We need not enlarge upon the value of grit for poultrv. Every poultryman knows how necessary it is to their welfare. In ordering please state whether you want chick size or poultry size. Price, 100 lbs., \$1.00.

\section{Granulated Charcoal}

Our Granulated Charcoal is guaranteed pure. It is not ordinary commercial charcoal, but is especially prepared for poultry, containing no foreign matter, or anything in any way harmful to the chickens or ducks. It is an excellent conditioner, aids digestion, purifies the blood, keeps the crops sweet, regulates the bowels and promotes the general good health of the chicks and adult fowls. Granulated Charcoal is prepared for us in two sizes, viz.: Fine granulated, for all mash rations and for small chicks and a coarser granulated for adult fowls. Price, 10c per lb.; 10 10s., 50c; 50-1b. sacks, \$1.50; 100-1b, \$2.75.

\section{Oyster Shell}

Every poultry house or yard should have a pan or box filled with crushed shells, so that the fowls can have access to them at all times. Oyster shells prevent soft shell eggs, makes the egg shells strong enough to carry without breaking and makes eggs larger and heavier. Price, 10 lbs., 2.ic; 100 lbs., \$1.50.

\section{Western Shell}

A good grade of sea shell. Price, 100 lbs., \$1.00.

\section{Granulated Bone}

Many poultry men prefer granulated bone to fresh or green bone. Fresh or green bone contains 53 per cent of moisture and 12 per cent of grease, so that when a poultryman buys fresh bones he pays for 65 pounds of useless materials in every 100 pounds he buys. Granulated Bone, while more expensive as a rule than green bone, fully makes up for the difference by its concentrated value. It is made from fresh bones with the moisture and grease taken out, leaving nothing but the phosphate of lime and introgen. Price, 10 lbs., 40c; 100 lbs., \$2.75.

\section{Oil Meal}

Oil Meal is an extra good food for poultry, cows, horses or calves. If fed to cows, it increases the milk flow and is a material help in calving. If properly fed calves can he entirely raised upon it. Price, 7 lbs., 25c; 100 lbs., \$2.75.

\section{"'Proteina"' Soy Bean Oil Meal}

Niore Than Half Again as Rich as Linseed Oil Meal-More Than Double the Feeding Value of Corn

All animals, including horses, young lambs and carves, eat "Proteina" readily without any disturbing effect on digestive organs such as is usually experienced when feeding other oil meals-this feature makes it especially valuable where forced feeding is desired.

"Proteina" is unequaled as a feed for dairy stock, producing immediate increases in milk and butter fat, as is abundantly proved by actual tests.

"Proteina" is unsurpassed as a poultry food owing to the large amount of albumen it contains.

Price, 7 lbs., 25c; 100 lbs., \$2.50.

\section{Blatchford's Calf Meal}

As Rich and Nutritious as Milk at One-Half the Expense 100 Pounds Makes 100 Gallons of Perfect Milk Substitute

Blatchford's Calf Meal is the Standard Milk Substitute of the world. The export trade on it alone is more than the total trade of all other calf meals combined. It is absolutely the only Milk Substitute that contains all the elements necessary for bodilv growth in the correct proportion, and it is the only calf meal that is thoroughly cooked and prepared for digestion by the tender stomach of the very young animal. It pushes pigs, colts, lambs, etc., forward better and quicker than any other food.

Price, 25 lbs., \$1.50; 50 lbs., \$2.75; 100 lbs., \$5.00.

\section{Feed Grains}

We keep in stock for feed, wheat, screened cracked wheat, corn, screened cracked corn, barley oats, bran, shorts, etc. As above feeds fluctuate so in value we do not list prices, but will be pleased to quote upon application.

How to make money out of Poultry: Feed Clover Leaf Brands of Poultry Feed. 


\section{Stock and Poultry Remedies}

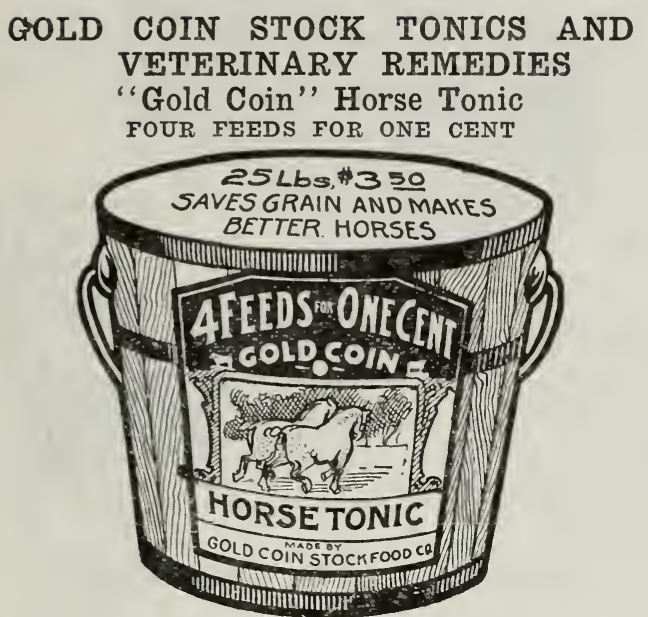

A Horse Tonic for Horses Only

It hardens the muscles. It gives extra strength, speed, style, action and endurance. It aids digestion. It purifies the blood and sleekens the coat. It clears the water, regu lates the bowels, cures and prevents disease. It keeps mars and colts healthy. Made from pure roots, barks, seeds and herbs.

GOLD COIN HORSE TONIC-Sold in 25c. 50c and $\$ 1.00$ packages. In $121 \frac{1}{2}-1 \mathrm{~b}$. pails, $\$ 2.00 ; 25-1 \mathrm{~b}$. pails, $\$ 3.50 ; 50$ lb. tubs, $\$ 6.50 ; 100-1 b$. barrels, \$12.00.

\section{"Gold Coin" Hog Tonic}

This is the only scientific preparation on the market today made especially for fattening and conditioning hogs. Every hog raiser needs this great "Hog Tonic." It makes extra money for every farmer who uses it, by saving ot feed, rapid growth, quick fattening and prevention of diseases.

FEEDING HOGS-If your hogs are in good condition, feed one measureful of "Hog Tonic" twice a day to each full-grown hog. If not thriving, feed two measurefuls three times a day until in good condition and thell reduce to one measureful twice a day.

QUICK FATTENING-For very rapid fattening give two measurefuls of "Gold Coin Hog Tonic" to each hog three times a day. If necessary to hurry the fattening, you may use three or four measures three times a day to each hog. Mix the "Tonic" with the slop water or sprinkle it over the feed.

GOLD COIN HOG TONIC-Put up in 25c and $50 \mathrm{c}$ packages; also in $25-1 b$. pails, $\$ 2.00 ; \mathbf{5 0 - 1 b}$. tubs, $\$ 3.75 ; 100$. lb. barrels, $\$ 7.00$.

\section{"Gold Coin" Poultry Tonic}

IT MAKES HEN S LAY-It is the greatest egg producer ever invented. A few weeks' rial of it will prove its value. It contains the stuff that helps $n$ e n s make eggs.

IT PREVENTS AND C URES C I I K K N CHOLERA - It is the cheapest and best poultry tonic on the market today. It will cure and prevent all poultry diseases, and saves feed. It fattens in half the usual time and makes extra money for you both in increased egg production and in raplo growth of roung fowls.

It is not what your poultry eats, but what they algest and turn into flesh and production of eggs that makes money for you.

GOLD COIN POULTRY TONIC-Put up in 25c, $50 \mathrm{c}$ and $\$ 1.00$ packages; also $12 \frac{1}{2}-1 \mathrm{~b}$. pails, $\$ 2.00 ; 25-1 \mathrm{~b}$ pailsfi $\$ 3.50$

\section{"Gold Coin" Cattle Tonic}

A Scientific Cattle Tonic for the Dalry

Prepared especially for cattle and sheep. It is the mos scientific conditioner and fattener ever discovered. When fed to steers or dry cows it increases the flow of milk and the butter fats (cream). When fed to sheep it in creases the growth, mutton and wool. To young stock it gives health and rapid growth. It is a tonic for loss of appetite, and a preventive for scours in calves.

GOLD COIN CATTLE TONIC-Has been a money-make for thousands of farmers and cattle raisers, and it will make money for you if you feed it faithfully as directed above. It will fatten in 30 to 40 days less time. Put up in 25c and 50c packages; also in 25-1b. pails, $\$ 2.00$; 50lb. tubs, $\$ 3.75 ; 100-1 b$. barrels, $\$ 7.00$.

\section{"Gold Coin" Remedies}

GOID COIN FOOT REMEDY-Quickly cures sore feet, ameness from corns, sand cracks, quarter cracks, tracted heels, etc. Per can, 50c.

GOLD COIN LOUSE POWDER-Kills lice, ticks, mites n poultry, pigeons, dogs, cats, stock; also plant lice, mites, etc. Per can, 25c.

GOLD COIN LICE KILLER-To kill lice in hen houses, og pens, stables, etc. Quarts, 35c; half gallon, $60 \mathrm{c}$; uut gallon, $\$ 1.00$.

GOID COIN HARNESS OIL-For oiling harness or pre serving any kind of leather. Per can, $25 \mathrm{c}$

GOLD COIN HARNESS SOAP-For cleaning and polishing harness, buggy tops, shoes and all kinds of leather. Per can, 25c.

GOLD COIN WORM POWDER-Kills all worms and bots in horses, hogs, sheep, dogs, etc. Per package, 50c.

GOLD COIN HEALING OIL_For barb wire cuts, nail injuries, burns, scalds, flesh wounds or cuts, on man or beast. Per bottle, 25c and 50c.

GOLD COIN COLIC CURE-Cures windcolic blont, spasmodic colic, stoppage of urine, etc. Per bottle, 50c.

GOID COIN COLD AND DISTEMPER CURE-A spe-

ific for distemper in young or old horses. Quickly cures colds, coughs, etc. Per package, 50c.

GOID COIN SPAVIN CURE-For curable spavins. Quickly reduces all soft swellings as "bog'" spavin, blood spavin, swollen joints, inflammation, etc. Per bottle, \$1.50.

GOLD COIN CONDITION POWDER-For sick animals A high-class medicine for fevers and all acute diseases. Per package, 50c.

GOLD COIN GALI CURE-For sores on neck, shou!ders and back from rubbing of harness or saddles. All cuts or wounds on horses. Be sure to work the horse while using it. It cures best while working. Per can, 25c and 50c.

GOLD COIN GERM IIILER-The most practical disinfectant for stables and outbuildings. Destroys all disease germs, cleanses and purifies filthy places, thus preventing causes and spread of diseases. Per can, 25̌c and 50c.

HEAVE CURE-It is the best and cheapest heave cure. It is a recent discovery and is curing cases which all other remedies have failed to touch. Per package, 50c.

LUMP JAW-Cures the disease known as lumpy

which is due to a microorganism. Price, $\$ 2.00$.

\section{"Gold Coin" Compound Liniment}

THE WORID'S GREATEST CURE FOR I.ATEENESS Rub the affected parts thoroughly with the liniment.

\section{"Gold Coin" Cough and Lung Syrup}

This is a cough syrup for horses, cattle, sheep or hogs. If given in time it will prevent many serious diseases, such as pneumonia, bronchitis, consumption, etc. It is important to attend to all lung diseases promptly. Per bottle, $75 \mathrm{c}$ and $\$ 3.50$.

\section{"Gold Coin" Sheep Dip}

\section{GOID COIN SHEEP DIP-Is a new scientific “} founded on scientific principles and does what other "dips' now on the market will not do. It is cheaper, stronger and safer than any other "dip." It goes further. Te can sell it to you cheaper than you can make up a "dip" for yourself. Put up in the following sizes: One gallon, \$1.50; 5 gallons, $\$ 6.50 ; 10$ gallons, $\$ 12.00$. 


\section{CONKEY'S REMEDIES}

\section{POULTRY DISEASES -}

Every poultry raiser should study the subject of Poultry Diseases. It is very important to know the common symptoms so as to understand what the trouble is and what to do for it. It is also in. portant to understand the cause for each disease, and thras know how to prevent trouble in the first place. Most diseases are preventable. especially those which are hardest io curt. If you do not know all about poultry ail. ments, the best thing is to get a copy of Conkey's D ml. try Book and study it thor onghly. It takes up the sub

jects of Housino. Feeding. Management, as well as diseases. It covers chickens, turkeys, ducks and geese. One man writes: "I got more good working ideas from Conker"s Poultry Book than any other chicken lonok I ever read.' It is practical and common-sense throughout. Contains st pages, well illustrated. Price 50c, but sent FREE for stamps is for mailing.

Wie handle the complete line of Conkey's Poultry Reme dies. Followino are some of the most important. Read these pages carefully for some of these remedies you will want to keep on hand. It is well to be prepared before trouble starts. Disease comes suddenly, it snreads rapidly. and while you are waiting to get the right treatment, you may lose your flock.

CONKEY'S ROUP REMEDY-Here is one remedy that should be on every poultryman's medicine shelf for use at the very first symptom of sneezing, coughing or moping. I'se it as a preventive as well as a remedr and put it in the drinking water when the weather is unsettled, thus avoid all danger of cold and roup. A little of it occasionally is a good tonic. Remember that roup is highly contaoious. Neglect to treat promptly endangers your whole flock. But even in neglected stages don't despair, but use Conkey's Roup Remedy according to the special directions for worse cases. Tre guarantee this treatment $\longrightarrow$ your money back if it ever fails you. Price, 50c and \$1.00; postage, $6 \mathrm{c}$ and $12 \mathrm{c}$.

CONKEY'S BRONCHITIS REMEDY-Bronchitis is different from roup, and needs a special treatment which will reach the bronchial tubes. Conkey's Poultry Book tells how to distinguish bronchitis. Price of this special remedy, 50c; postage, Sc. Money back guarantee.

CONKEY'S CHOIERA REMEDY, for indigestion, bowel trouble and all so-called "cholera" ailments of chicks and grown fowls, so common in spring and summer. The sick birds get the modicine as ther are very feverish and drink thirstily. Price, J0c; postage, Sc.

CONKEY'S WHITE DIARRHOEA REMEDY is a special preventive and remedy for this dread scourge of incubator chicks. All poultrymen know the symptoms of this terrible disease and the forlorn, humped-up appearance of the luaby chicks. Conkey's White Diarrhoea Remedy is successful even in bad cases, if the hardened accumulation around the vent is removed as directed in Conkey's Poultry Boow. The best way is to use it as a preventive. If given to breeding stock it will prevent infection at its source. Given in drinking water. Have it on hand next hatching season and save your chicks. Price, 50c; postage, $7 \mathrm{c}$.

CONKEY'S GAPE REMEDY-Here is another chick saver. Gapes is a troublesome disease, tedious to cure, but this remedy is highly successful. Easily given right along with the water and feed, so there is no troublesome individual treatment. Money back guarantee. Price, 50c; postage, 1Sc. NOTE-Read Conkey's Poultry Book on how to prevent gapes.
CONKEY'S HEAD LICE OINTMENT is another lifesaver for little chicks. If a chick droops always look for lice, for two or three of these big fellows on head, neck or under wing can actually murder a little chick. It's easy to kill the head lice without hurting the chick if you use Conkey's Head Lice Ointment. Just a touch of it will be enough. Price, 10c; postage, 2c; 25c, postage 4c. Easy and pleasant to use.

NO'TE-In Conkey's Poul. trv Book you will find much useful information on little chicks.

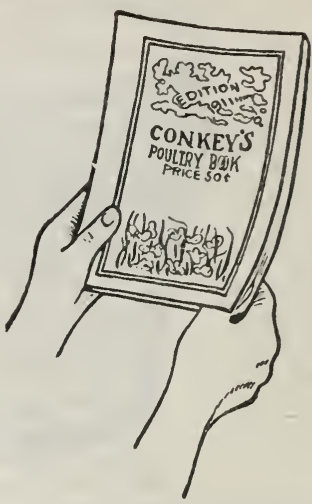

CONKEY'S CHICKEN-POX OR SORE-HEAD REMEDY - Sore-head is getting to be one of the most serious troubles. Treat it promptly and save your flock. Price, 50c; postage, $10 \mathrm{c}$.

CONKEY'S IIMBER NECK REMEDY-You will not lose a bird from limber neck if you give this medicine prompily. Usually one day's treatment is enough. Price, 50c; postage, 12c.

CONKEY'S SCALY LEG REMEDY-Keeps the feet in nice shape and is just the thing for getting show birds ready. Price, 2:ic; postage, 6c.

CONKEY'S POULTRY LAXATIVE-Very dependable and suited especially to fowls. Purgative or laxative, according to dose. Price, 25ic; postage, 6 c.

- CONKEY'S POULTRY TONIC-For general run-down condition; or you can use it for little clicks that are not making good growth. This is a fine general tonic during moulting season or after recovery from any disease. It is much used for conditioning show birds. Price, 25c; postage, $\mathbf{9 c}$.

CONKEY'S LICE POWDER-When the fowls don't do well always look for lice. If you don't find them, look again. Lice and poultry go together. But lice and profits never go together and you must rid your fowls of lice if you want poultry satisfaction. Conkey's Lice Powder is excellent for ridding fowls of body lice, as it quickly kills these pests when sifted into the feathers of the bird, and it does not injure the fowls or eren taint eggs in the nest. Just the thing for setting hens and for dusting the nests. A great big package will be sent you free for stamos $4 c$, so you can test it. Regular packages, 25c (15 oz.); joc (48 oz.), and $\$ 1.00$ (100 0z.); express extra.

CONKEY'S LICE LIQUID FOR MITES-Spraying walls and painting roosts, cracks and crevices is the only way to rid houses of mites. Conkey's Lice Liquid is a highly satisfactory lice spray and paint as it kills the pests, but is safe to use as it will not catch fire or explode. It is also cheap, as it mixes with water. Use Conkey's Lice Liquid and you will not have to whack up your poultry profits with mites. Price, $\$ 1.00$ gal.; 2 quarts, 60c; qt., 3.ic; expressage extra.

For Stock Books, see Page 74. 


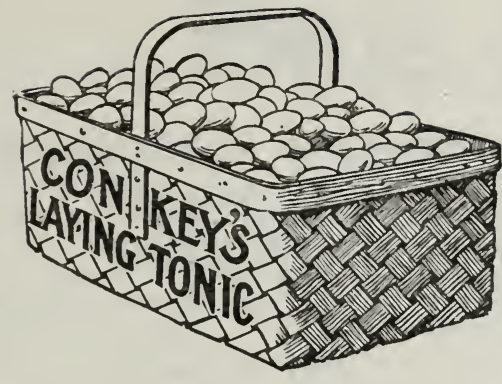

CONKEY'S LAYING T'ONIC-Lots of people don't believe in forcing feeds. But everybody wants eggs in winter when eggs mean money. Conkey's Laying Tonic fills the egg basket in spite of weather. It is not a food, but all tonis medicine to be mixed with the regular feed during seasons when fowls get sluggish and want to loaf instead of lay. It is rery economical, as you mix it in small quantities with the regular feed, the packages containing all pure medicines, no filler or foodstuff whatever. Prices, $25 c$, 50c, $\$ 1.00 ;$ pails, $\$ 1.60$ and $\$ 3.00$; express extra.

\section{CONKEY'S DOG REMEDIES}

CONKEY'S DOG REMEDIES-Tery dependable. We sell on guarantee.

CONKEY'S DISTEMPER REMEDY-Price, 50c; postage, 10c.

CONKEY'S MANGE REMEDY-Price, 50c; by express,

-ic. Also for eczema, canker, sore ears, ringworm, etc.

CONKEY'S WORM DROPS-Príce, soc; by express, 65c.

\section{CONKEY'S STOCK REMEDIFS}

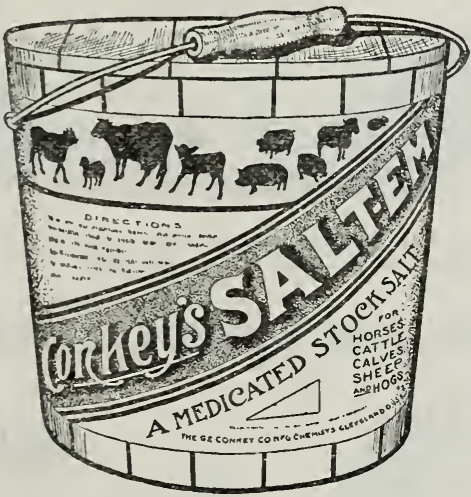

\section{SALT-FIM}

\section{Conkey's IMedicated Salt}

What it will do:

Rid your stock of worms.

Increase appetite.

Improve digestion.

Save waste of feed.

Tone up liver and kidneys.

Increase circulation.

Clean the blood.

Keep the system open.

Make thrifty gains from feed.

IVard oif disease.

Sold on a positive guarantee that if it does not give perfect satisfaction money will be refunded cheerfully. Prices: 100-pound kegs, $\$ 6.00 ; 40$-pound pails, \$2.75. 20-pound pails, \$1.50; 10-pounã pails, 90c.

Remember, we sell all Conkey Remedies on guarantee. Your money back if any Conkey Remedy ever fails you. THE INLAND SEED COMPANY.
CONKEY'S STOCK TONIC-An occasional conditione must be used for all farm stock or they cannot be pushed to the limit of production. Conkey's Stock Tonic is a perfect cnditionar for cows or feeding cattle horses, sheep or logs. It keeps up appetite, insures full digestion of the ration, prevents waste of feed, that is, brings you the most possible return for every pound of feed. Not a food itself, but all medicine, to be mixed with regular feed, by the spoonful, or with salt ( $1 \mathrm{lb}$. to 90 $1 \mathrm{lbs}$. salt) to make home-made stock salt. Not a particle of filler in this, you get the filler out of your own feed bin, at home prices. Money back. Prices: 1 lb., 25c; $21 \frac{1}{4}$ lbs., 50c; 5 lbs., \$1; 12 lbs, (pail), \$2; 25 lbs. (pail) \$3.50. Postage on small packages by mail 1c per oz. Express extra on pails. Buy it by pailfuls. You can afford to. It pays for itself every time.

CONKEY'S WORM REMEDY- $\Lambda$ promnt and powerful remedy for stock badly infested. Price, 50c.

CONKEY'S HORSE TONIC-A stimulating medicine for debilitated and exhausted conditions. Put out especially for fine bred horses. Price, $\$ \mathbf{1 . 0 0}$.

CONKEY'S HEAVE REMEDY-Corrects digestive dis turbance as well as nervous derangement. Tones organs back to health. Price, \$1.00.

CONKEY'S COLIC REMEDY-A lifa-saver and should be ou hand for emergency. Prices, 50c and \$1.00.

CONKEY'S FISTULA AND POLL EVIL REMEDYEffective and very humane. Price, \$2.00.

NCONKEY'S DISTEMPER AND COUGH REMEDY-For all cases of cough, cold, chill and fever, epizootic, distemper or strangles, pink eve, etc. Price, 50c and \$1.00.

CONKEY'S HEALING POWDER-A wonderful gall cure. For chafes, sores, etc. A perfect dry pressing (antiseptic) for surgical cases. Prices, 25c and 50c.

CONKEY'S GALI SALVE-A healing ointment for sores, cuts, harness and saddle galls, chafes, etc. Prices, 25c and 50c.

CONKEY'S FLY KNOCK. ER-All the time your stock are pestered by flies you are losing vour proflts. TVe guarantee Con k e y's Fly Knocker as an absolutely satisfactory fiy spray. Use it on your horses and cattle night and morning and see the difference in the work they do for you. Not an expense, because it makes money for you, besides saving time in handling, and bringing peace to you and the stock. Does not injure the hide, odor will not taint milk. Keeps fiies off. kills every one it hits, prevents lice and …h, saves shoes and floors from stamping, s a ves milk. saves flesh. saves feed. Price, qt., 50c 2 qts., $75 \mathrm{c}$; gal., $\$ 1.25$; express or freight.

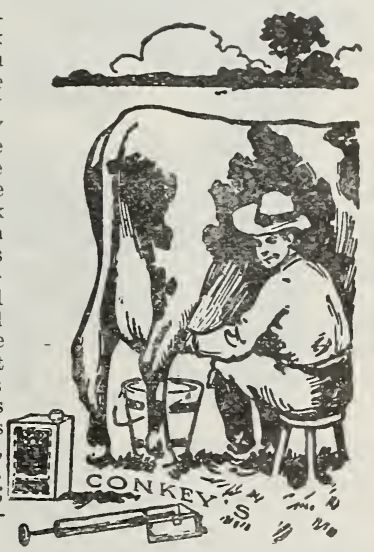

CONKEY'S PAIN LOTION-For soreness, throbbing pains, inflammation, cuts, wounds, burns. Price, 50c.

CONKEY'S HOOF REMEDY-Keeps your horse's hoofs in nice shape, thus preventing accidents. Price, pt., 50c; qt., 75c; 1/2 gal., \$1.25; 1 gal., \$2.00.

CONKEY'S ABSORBENT-Takes place of blistering and firing. Cures lameness, removes blemishes. Price, \$1.00.

CONKEY'S BAG OINTMENT-A penetrating, softening application which soothes quickly. A remedy for many bag troubles. Price, 25c and 50c.

BIG BOOK ON T.TVFSTOCK MANAGEMENT-OUR SPECIAL FREE OFFER-If you are interested in farm animals send us name and address and stamps ten cents and we will mail you one copv CONKEY'S STOCK BOOK. a new big hand-book of 224 pages. Positively "The best book yet on livestock!" THE INLAND SEED COMPANY, Spokane W ashington. 
CONKEY'S NOX-I-CIDE-The best way is not to have any diseases in vour flock. It is always easier and cheaner to prevent than to cure. Conkey's Nox-i-cide is an allaround preventive, as it keeps the quarters sanitary and kills the germs. Use it as a dip, disinfectant, spray or as a lice liquid. Mixes with water, so it's cheap enough, every gallon making from 50 to 100 gallons ready to use. Price, \$1.50 gallon. Also in smaller sizes, 2 qts, 90c; qt., (60ic; pint, 35c.

\section{ZENOLEUM}

\section{Disinfectant Animal Dip Lice-Killer}

One gallon of Zenoleum makes 100 gallons of positive disinfectant and germicide. Won't poison; won't hurt you; won't explode or burı. Kills vermin, cures skin trouble. Invaluable as a remedy for diseases of poultry and all live stock. Kills lice and cures mange. Disinfects incubators.

Price List Zenoleum Disinfectant and Dip

Eight ounces makes 6 gal. of fluid..............\$0.25 One quart makes 25 gal. of fluid Half gallon makes 50 gal. of fluid

One gallon makes $\mathbf{1 0 0}$ gal. of fluid

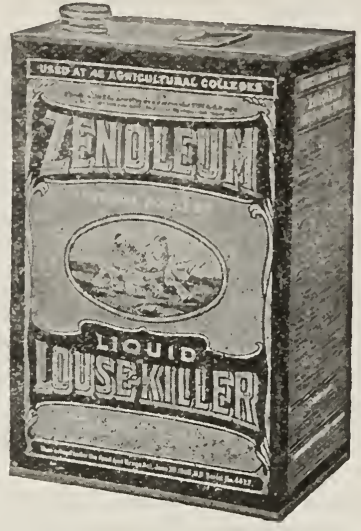

\section{AVENARIUS CARBOLINEUIM}

Avenarius Carbolineum is without doubt the most effective exterminator of mites and lice on pouutry, poultry houses, lice on horses, cattle and hogs, ticks on sheep, fleas on cats and dogs.

\section{Fror Chickens}

For chickens simply paint wa!ls, roosts, floors and roots of the poultry houses or barns after first thoroughly cleaning them. It does not make a particle of difference whether the interior is of wood, plaster or tar paper. One coar of Avenarius Carbolineum kills instantly all mites, bugs, nce and vermin. It is also a strong antiseptic and disinfectanc. The result is healthy chickens and more eggs. On the other hand a neglect to destroy vermin means the destruction of your chickens, especially very young ones, by disease.

\section{For Fiorses, Cattle and Sheep}

Sprinkle some on an old blanket and tie around the animal for several hours. Also paint the stalls.

\section{For Hogs}

Sprinkle a little Avenarius Carbolineum diluted with water on the bedding and also paint the hog pen.

Avenarius Carbolineum is not only an effective remedy for vermin but the most effective preservative for woodwork and paint known to the world. It is verv powerful and therefore economical and at the same time the quickest, surest and most effective lice killer. Price, qt., 50c; gallon, $\$ 1.50$.

\section{Tobacco Dust}

For use in dust baths or nests. A cliean and effectire exterminator of lice. Price, per ib, 10c; postpaid, $25 \mathrm{c}$.

\section{Poultry Pepper Compound}

This is a splendid tonic at all times. A small amount sprinkled in with a hot mash will stimulate the circulation and increase egg production. Price, per pkg., 250; postpaid, 40c; by freight, 5 lbs., \$1.00.

\section{Lice Powders}

BUFACH-Per 0z., 10c; 1/4 lb., 30c; lb., \$1.00.

PERSIAN INSECT POWDER-Lb., 50c.

\section{Copperas}

A small piece placed in drinking water is a good tonic for chickens. Per lb., 10c.

\section{Foods and Specialties for Birds Dogs \& Fish}

CANARY - Per 1b., 10c; postpaid, 20c.

HEMP - Per lb., 10c; postpaid, 20c.

RAPE-Per lb., 10c; postpaid, 20c.

MILLET-Per lb., 10c; postpaid, 20c.

CUTTIE BONE-TWO for 5c.

SUNFLOWER-Per lb., 25c postpaid; 12 lbs., \$1.0(), express or freignt.

\section{Bird IManna}

Keeps cage birds in constant song, improves their plumage and prevents disease. Price, 15c; postpaid, $20 \mathrm{c}$.

SPRATT'S SONG RESTORER (Dunlap's) - A treat and tonic for canaries, linnets, and all seed-eating birds. Price, 15c; bl mail, 20c.

SPRATT'S BIRD LICE DESTROYER (Henning's)For dusting the feathers. Price, 15c; by mail, 20c.

SPRATT'S BIRD TONIC (Henning's) - For the prevention and cure of all diseases which cage birds are subjecter to. Price, in bottles, $15 \mathrm{c}$; not mailable.

SPRATT'S PARROT FOOD-A mixed food for parrots which should be kept before them all the time. Price in cartons, 15c; postpaid, 25c.

SPRATT'S "DEFIANCE" MOCKING BIRD FOODThe purest fod obtainable for mocking birds, ronins, thrushes, and other soft-billed birds. Price in tins, 25c; postpaid, 25c.

SPRATT'S FISH FOOD-The best food for rearing trout, etc. Used at the leading trout hatcheries. Price, 10c; postpaid, 15c.

SPRATT'S PUPPY EISCUITS (The Standard Puppy Food) - A perfect and whole food for puppies of all breeds Puppies should be started on these biscuits when about one month old and they should be continued until such time as their teeth become sound and strong. usually when they are about six months old. Follow directions on each package. Price, 35c, express or freight.

\section{Dog Biscuit}

SPRATT'S-The analysis of our biscuits show that they are weight for weight, equal in nourishment to fresh raw beefsteak and superior to it as a food for dogs. The standard dog food; a staple and constant food for all breeds of dogs. Price, 3-lb. cartons, 35c; express or freight.

\section{Insect Powder Blowers}

JUMBO-Price, 25c; postpaid, 35c.

DEFENDER-Price, $15 \mathrm{c}$; postpaid, $2 . \mathrm{c}$.

\section{WOODLARK SQUIRRRL POISON}

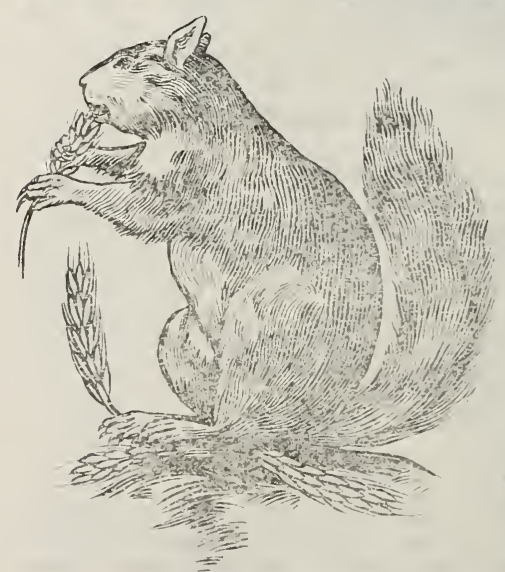

Kills Cophers Rats and

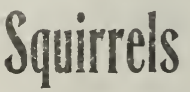

"The Brand that Kills"

Requires no mixing preparation-alwars ready for use. When you buy demand the best. Get the "Woodlark" brand. Money back if not as claimed.

Price 35c. Postpaid 55c. 


\section{Bee

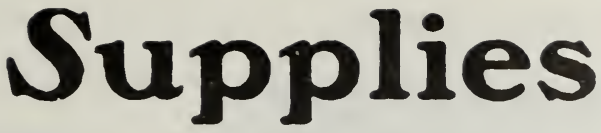

DOVETAILED HIVES-The doretailed hive is now the leading hive, as it contains many of the most desirable features of the various hives for the ranid handlino of bees, and is one of the cheapest and best hives manufactured. It is doretailed together, or rather put together with lock corners.

DESCRIPTION-The body is made of pine planed on both sides, $7 / 8$ inch thick, and is fitted with metal rbbets of an improved style. Outside of body is $137 / 8 \times 20$ i. whes, and $9 \frac{1}{2}$ inches long. The body holds eight Hoffman frames, $I$ size, and a division board. The frames hang below the top edge of the hive, so that there is a bee space above them, but the bottoms of the frames are flush with the bottom edges of hives, the bee snace being made by the projection of the sides and can be enlarged or decreased by

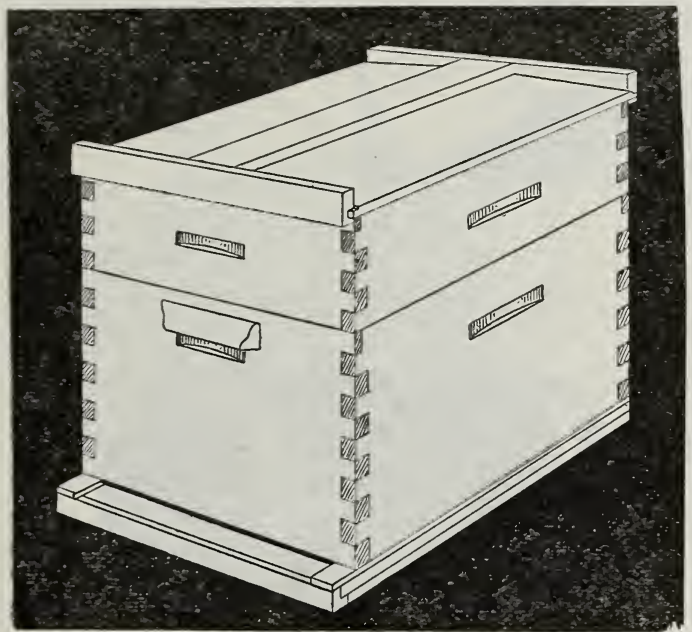

inverting bottom board. The bottom is $14 \times 21$ inches. The cover is made with grooved cleats at each end to prevent warping. The supers are the same size as the body of hive, but only half the depth, so that when two are put together they make a full-depth body. This hive is cheaply but accurately made, as the edges are square in place of being beveled as in the Simplicity. The inside width of the body is $121 / 2$ inches, giving room for eight frames and a division board. The sections in super are held closely together by wedge or tightening spring, which allows the use of $17 \%$ or 7 to a foot sections. There are objections to using sections other than $4 \frac{1}{1} \times 4 \frac{1}{2}$, as they require special sized shipping cases and special sized cartons; and there are other reasons that will suggest themselves to those who have had experience in using other than the regular sized goods. We put up this hive for shipment in lots of five by simply crating the pieces together, or packing them in solid crates.

NO. 1 DOVETAILED HIVE (COMPLETE WITH ONF SUPER)-Consists of 1 bottom board, 1 body, 1 super, 1 cover, 8 Hoffman brood frames, 1 division board, 2 wedges for super, 6 section holders, 6 slotted separators. Price, 5 K. D., \$\$.7.5; 1 nailed, \$2.00.

SECTION HOLDERS-Each, 3c: 100, \$2.25.

SLOTTED SEPARATORS (SAWED)-Ten for 15c; 100, $\$ 1.00$.

SUPERS-Same as above hive. Each, 75c; 5 in flat, \$3.25.

\section{Section Honey Boxes}

NO. 1 SECTIONS-Are made of the choicest white basswood lumber. and all are perfect in finish and free from defects. They are not all snow-white, but vary from that to light cream color. Price, per 25, 25c; 100, 75c; 500, $\$ 3.50 ; 1,000, \$ 6.50$.

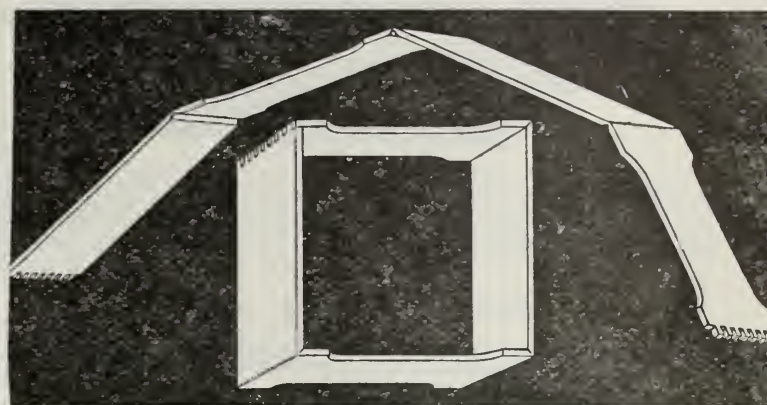

NO. 2 SECTIONS-Selected from the best grade, sell at price less than the No. 1. Most of them are equal to No. 1 except in color; some have dark spots, saw marks, or nther blemishes which exclude them from the No. 1 grarle. Price, per 25, 25c; per 100, 70c; per 500, \$3.25; per 1,000 $\$ 6.00$.

\section{Hoffman Brood Frames}

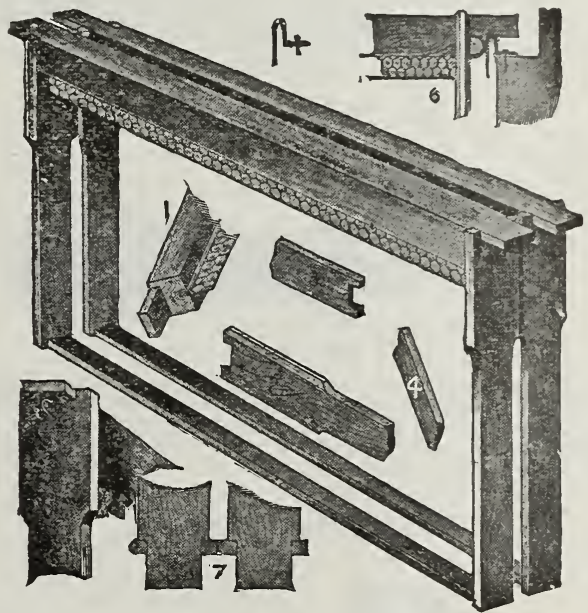

The Hoffman Improved Foundation Fastening Frames are the latest and best brood frames out. The top bar is made with a beveled strip which holds the foundation absolutely in place, perfectly straight and exactly in center to top bar. Anyone can put foundations in these frames very rapidly. It seems to combine in itself nearly all the good features and for a hanging frame it is the best self-spacer we know of. It economizes labor in that it can be handled in groups of three or four; and any particular frame can be removed without thumbing over nearly all the other frames in the hive to get room. Price, per $S$, 30c; 100, $\$ 3.25$.

\section{Van Deusen Wax Tube Fastener}

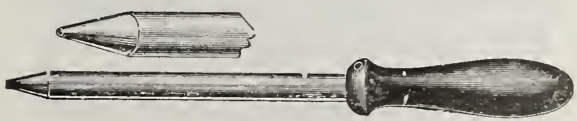

For fastening the foundation sheets to thin top-bars there is nothing better than the Van Deusen wax tube. It is simply a brass tube half an inch in diameter, six inches long and tapering. This is filled with hot wax and the point is then slowly drawn along the edge of the foundation in contact with the top-bar, leaving a fine stream of hot wax to cement it. Price, 20c each; by mail, 25c. 


\section{Bee Entrance Guards}

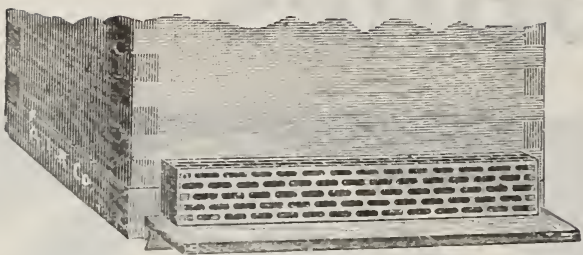

These are to admit workers, and to exclude drones. After the drones are all out, fix the guards over the entrance and at night the drones can be destroyed. Price, 15c; by mail, 20c.

\section{Queen Excluding Zinc}

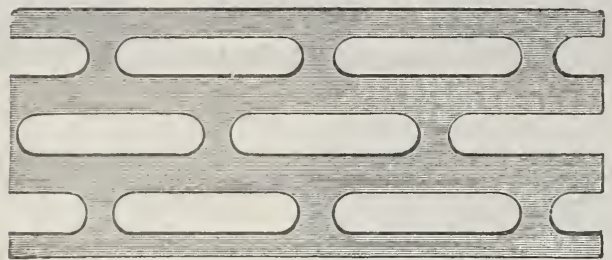

We carry in stock one of the best zincs, with oblong perforations. This is used between the upper and lower stories, to prevent the queen going up above. It is aiso tised in making entrance guards. queen and drone traps, etc. Price, 30c each; by mail, $45 \mathrm{c}$.

\section{Spur Wire Imbedder}

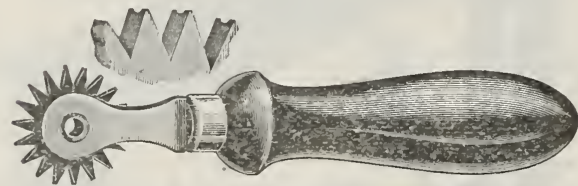

Price, 20c; by mail, 25c.

The latest spur wire imbedder is a most decided improvement over the old one. The teeth are wider and grooved in the direction of the circumference midway across front of teeth, so that the wheel will easily follow the wire. The result is beautiful work.

\section{Foundation Fastener}

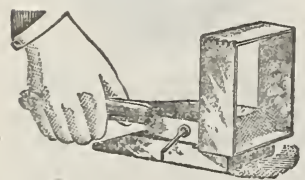

Parker

PARKER'S-The Parker Fastener is a cheap machine for fastening starters. With a little practice it can be made to work very satisfactorily. Price, each, s.sc; by mail, 50c.

\section{Daisy}

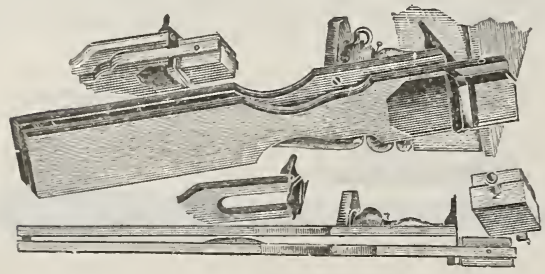

DAISY-This is the best for putting starters into sections. Nothing could be more simple or more easily operated than this machine, and we are sure it will put starters in better and faster than any machine before produced. With this a boy or girl will put starters in about 500 sections per hour. Price, without lamp, \$1.00; with lamp, \$1.25.
Manum's Swarm Catcher

This swarm catcher is the best article of its kind on the market, and it will be found a valuable addition to the apn!iances of the apiary. Price, without lamp, \$1.00; with lamp, \$1.25.

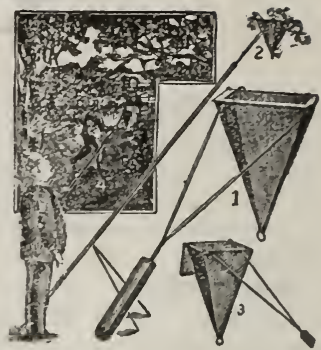

\section{Queen Cages}

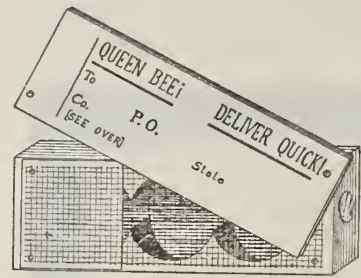

Price of Queen Cages, as above, oc each. These are complete, withont candy.

The cover, to insure prompt delivery, is printed in exact fac-simile of the cut. On the reverse sicle are printed directions for intrn. ducing Queens,

\section{Tinned Wire}

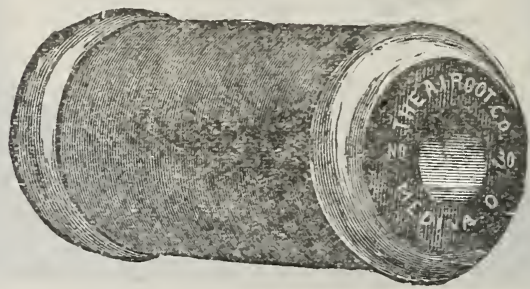

No. 30 Tinned wire seems to be the most suitable of any for wiring frames. We keep it in stock on spools as listed.

Sizes Furnished-

PRICE Post

Each Doz. Each 1/4-1b. Spools No. 30 Tinned Wire.......\$0.1\% \$1.50 \$0.06 1/,-11). Spools No. 30 Tinned Wire....... .25 $2.50 \quad .10$ 1-1b. Spools No. 30 Tinned Wire........ .40 3.75 .1S

\section{Veils}

A great necessity and very cheap: cotton. Each, foc postpaid.

\section{Gloves, Rubber}

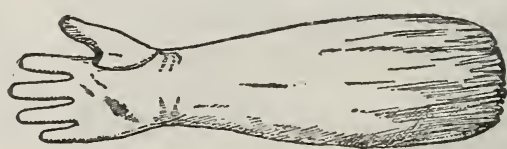

Rubber Gloves for the protection of the liands and wrists are almost indispensable in handling bees. Gents' sizes -0, 11 and 12 , each, \$1.50; by mail, \$1.60.

For Bee Books, see Page 74 . 


\section{Honey Extractors}

Novice Extractors

For those who want the smallest and lightest machine, as lwell as one moderate in price, this is the best in the market. It is a non-reversible, two-frame machine; that is, the frames must be pulled clear out of the extractor, reversed in the air, and put back into the baskets the other side to The Novice will handle the product of fifty or more colo. nies in good seasons. Price, \$11.00.
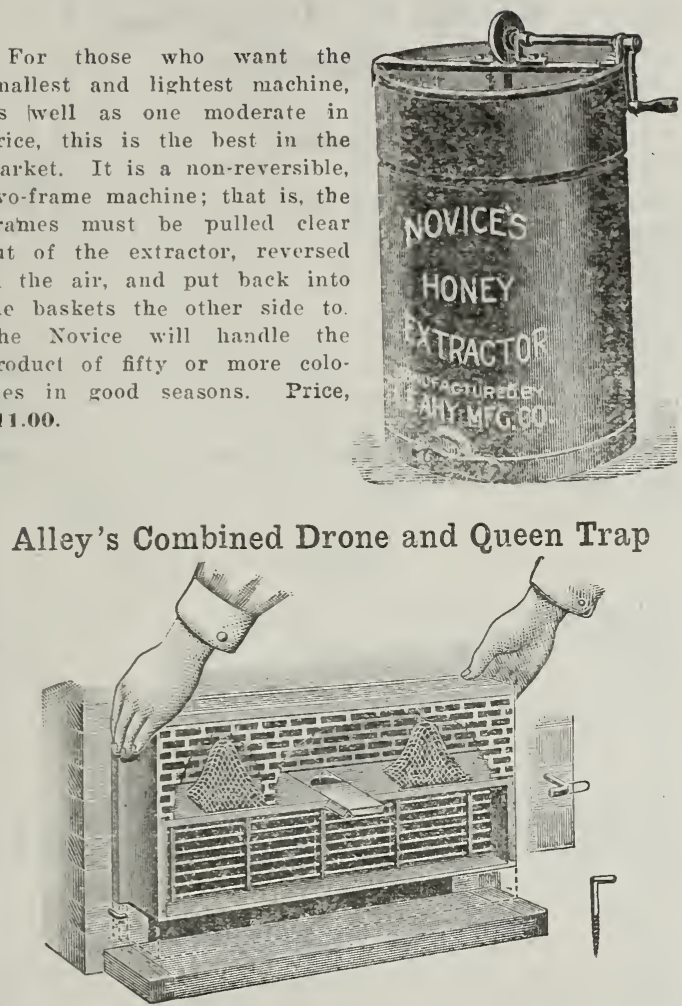

A perfect non-swarming arrangement. Each, 50c; by mail, $70 \mathrm{c}$.

The "Higginsville" Smoker

This smoker is, as its name implies, strictly a Hig. ginsville product. It is a hot blast, and has a $3 \frac{1 / 4}{4}$. incl fire box, and the nozzle is detachable to admit of filling or cleaning. It has as strong a blast is any smoker made. A bar of folded tin running parallel with a bel. lows protects the hand from coming in contact with the hot fire box. Price, each, \$1; weight, $13 / 4$ lbs.

The Higginsville Smoker

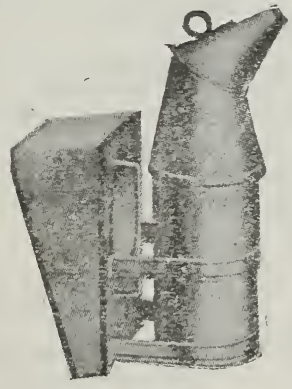

Porter Bee Escape

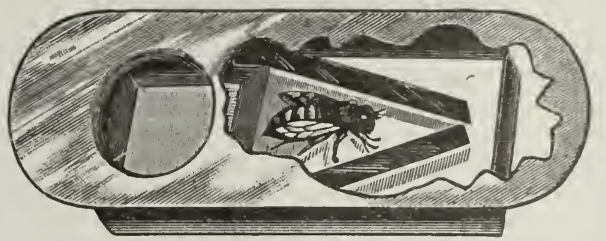

No apiarist can afford to be without bee-escapes any more than he can afford to be without a bee-smoker. In taking off honey it is the greatest labor saving device that has been introduced in late years. It avoids shaking heavy super's to get the bees out. Price, 25c.

\section{Feeding}

Bees are fed for two purposes: To stimulate brood rearing or to supply them with necessary stores for winter. For stimulating, a pint o half of syrup daily either at the entrance at night or inside the hive, should be given until the required amount of brood is reared. In preparing for winter it is better to give the necessary stores all at one feed.

\section{Simplicity Feeder}

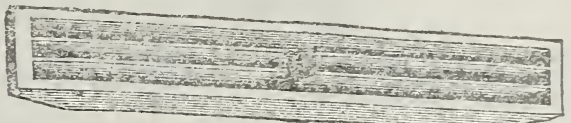

This is to be filled with syrup by mixing togetler granulated sugar and water in equal proportions by measure and stirring or heating until thoroughly dissolved. This feerler may be placed at the entrance at night, отer the broodframes, by placing on top of the hive or in the broodnest itself, if a couple of frames are removed. Price, $10 \mathrm{c}$ each; by mail, 15c each.

\section{The Use of Comb Foundation}

There is little question but that it pays to use founda tion in full sheets in the brood frames and sections, especially the latter. If you think you cannot afford so much you should at least have a strip for a starter. It will help you much more than it costs you, in getting straight, even combs. You can use a starter any width from one inch un. In sections by far the best results are obtained by using a bottom starter not over $1 / 4$ inch, and a full top starter reaching to within $1 / 4$ to $3-16$ of an inch of the bottom starter.

\section{Table of Prices of Comb Foundation}

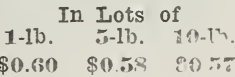

Medium Brood 6

Thin Super

Not less than 1 pound mailed. We consider this a dangerous way of sending these goods.

\section{Cogshall's Bee Brush}

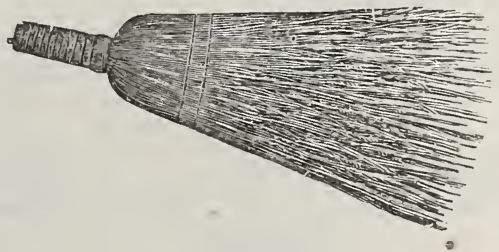

This is a sort of whisk broom especially adapted and made for brushing bees. The strands are thinned out and longer, so as to give a soft, pliable sweep to the combs.

Price, by mail, 25c.

\begin{abstract}
This is undoubtedly $t h$ best cold blast smoker on the market. It has no tube in the fire box to clog. It throws a large volume of smoke at right angles to the fire box without a curved nozzle to lessen the blast noz zle to lessen the rerfection of smokers. The large size has an arrangement whereby the draft can be regulated as required. Price, $75 \mathrm{c}$; weight, $13 \%$ Ibs.
\end{abstract}

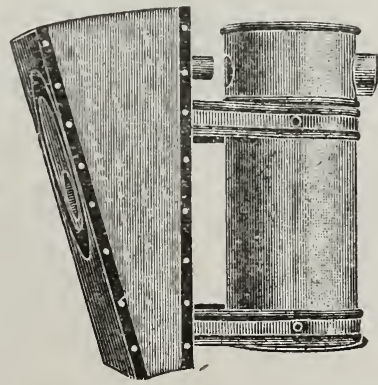




\section{EGGS FOR HATCHING}

In all undertakings it is of the utmost importance to have a good foundation or to begin right. This is as true in the poultry business as in any other undertaking, hence too much care cannot be given to the securing of eggs from strong, healthy stock, that will have strong germinating qualities and that in turn will produce strong, healthy chicks. We have selected with the greatest care those breeders that have made a special study of their stock, and have made their selection and their matings, not alone from the viewpoint of fenthers, but have made a c'ose study in continually selecting their breeding pens from their best laying stock, and わy so doing have produced strains that ranks high in the amnual production of eggs.

In order that our customers may know exactly whose eggs they will receive we give the name of the different breeders. These eggs are carefully packed and with reasonable care by the transportation companies should arrive at them destination safely. Prices quoted are F. O. B. Spokane. In order that our customers may rest assured that they will receive eggs from the breeders listed, we desire to state that we are oniv handling the eggs as lister from the breeders mentioned and will not handle any others.

\section{Bantams}

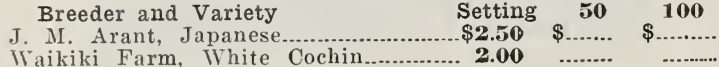

\section{Minorcas}

J. M. Fink, S. C. Black

J. G. Dickson, S. C. Buff

J. G. Dickson, S. C. Buff.

$\begin{array}{lll}\mathbf{2 . 0 0} & \mathbf{4 . 5 0} & \mathbf{8 . 0 0} \\ \mathbf{2 . 0 0} & \mathbf{6 . 0 0} & \\ \mathbf{5 . 0 0} & \text { Special } & \end{array}$

\section{Leghorns}

Waikiki Farm, S. C. Buff.................... 2.00

The Balmat-Skinner Co., S. C. White $\mathbf{1 . 5 0}$

The Balmat-Skinner So., S. C. White Special

H. J. Fuller, S. C. Brown

H. J. Fuller, S. C. Brown

H. J. Fu!ler, S. C. Brown

5.00

\section{Orpingtons}

J. M. Arant, S. C. White 2.50

15.00

\section{Rhode Island Reds}

Waikiki Farm, S. C

J. F. Dickson, R. C

2.00

2.00 5.00

$\begin{array}{lr}\mathbf{5 . 5 0} & 10.00 \\ \mathbf{3 . 5 0} & \mathbf{6 . 0 0} \\ & \\ 6.00 & 10.00 \\ 6.00 & 1000 \\ \text { Special } & \\ \text { Special } & \end{array}$

J. F. Dickson, R. C

\section{Rocks}

George S. Gaub, Barred

2.00

3.00

$\mathbf{5 . 5 0} \mathbf{1 0 . 0 0}$

Traikiki Farm, White

\section{Pheasants}

Breeder and Variety

Waikiki Farm, English Ring Neck.

\section{Setting}

$\$ 2.50$

\section{Turkeys}

Waikiki Farm, White Holland..

3.00 3.5c ea.

\section{Ducks}

Waikiki Farm, Indian Runner........................... 2.00

Wraikiki Farm, Pekin .................................. 2.00

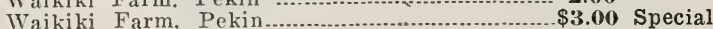

\section{Geese}

Waikiki Farm, White Embden...

\section{Standard Text and Reference Works by Recognized Authorities}

\section{Poultry}

Artificial Incubating and Brooding. Postpaid $\$(1)$

The Chick Book

Eggs and Eggs Farms

Egg Record and Account Book.

Poultry Houses and Fixtures

Reliable Poultrw Remedies.

Conkey's Poultry Book, 80 pages

Farm Poultry, 341 pages........................................... 1.

How to Keep Hens for Profit, 380 pages........................ 1.0.

The Philo System, 95 pages...................................... 1.00

\section{Stock}

The Feeding of Animals, 450 pages ................................ 1.65

The Horse, 400 pages...................................................... 1.40

Diseases of Animals......................................................... 1.65

Conkey's Stock Book, 225 pages...................................... .10

\section{Bees}

A B C and X Y Z of Bee Culture, 500 pages................ 1.75 How to Keep Bees for Profit, 348 pages.

\section{Farming and Gardening}

Dry Farming ......................................................... 1.65

Fertility of the Land, 421 pages..................................... 1.70

Fertilizers, 335 pages.................................................... 1.40

Irrigation and Drainage, 502 pages.......................... 1.70

Milk and Its Products, 311 pages................................. 1.70

Bush Fruits, 537 pages............................................. 1.70

Principles of Fruit Growing, 516 pages........................ 1.6.5

The Nursery Book, 365 pages...................................... 1.70

The Pruning Book, 537 pages............................................... 1.70

Plant Breeding ............................................................ 1.40

Manual of Gardening, 53t pages.................................... 2.20

The Principles of Vegetable Gardening, 458 nages........ 1.70

The Forcing Book, 266 pages....................................... 1.3.5

The Spraying of Plants, 399 pages................................. 1.35

Mushroom Culture, 32 pages......................................... .15

\section{Cultural Directions}

Annuals from Seed
The Dahlia
House Plants
The Sweet Pea
Asparagus
Mushroom Culture
Hot-Beds and Frames
Cabbage and Cauliflower
Celery
The Vegetable Garden

For a $50 \mathrm{c}$ order of package Flower or Garden Seed, any one of the above cultural directions will be sent free. 


\section{NUMBER OF PLA NTS TO THE ACRE}

\begin{tabular}{|c|c|c|}
\hline Dis. A & Apart & No. Plants \\
\hline $12 x$ & 1 & in ............. 502,270 \\
\hline $12 \mathrm{x}$ & 3 & in $\ldots . . . . . .174,240$ \\
\hline 12 & 12 & 43,560 \\
\hline 16 & 1 & $\ldots 352,040$ \\
\hline 15 & 1 & $\ldots 3+8,480$ \\
\hline 18 & 3 & 116,160 \\
\hline x & $12 \mathrm{i}$ & in \\
\hline $\mathbf{x}$ & 18 & in ........... \\
\hline $\mathbf{x}$ & 1 & (...313,63.5 \\
\hline $\begin{array}{l}x \\
x\end{array}$ & 20 & ... 15,681 \\
\hline $\begin{array}{l}x \\
x\end{array}$ & 24 & 10.590 \\
\hline $\mathrm{x}$ & 1 & in $\ldots . . . . . . . . . .2(i 1,301)$ \\
\hline
\end{tabular}

\begin{tabular}{|c|c|c|}
\hline Dis. & Apart & No. Plants \\
\hline $25:$ & $\times 18$ & $\ldots 15,520$ \\
\hline 30 & 1 & $. . .209,088$ \\
\hline 30 & 6 & $\ldots 34,848$ \\
\hline 30 & 12 & 17,424 \\
\hline 30 & 16 & 13,068 \\
\hline 30 & 20 & 10,454 \\
\hline & 24 & in ............ \\
\hline & 30 & in .............. \\
\hline & 3 & 58,080 \\
\hline 6 & 12 & 14,520 \\
\hline 6 & $\times 18$ & 9,680 \\
\hline & $x \quad 2 t$ & in $\ldots . . . . . . . . . .760$ \\
\hline
\end{tabular}

\begin{tabular}{|c|c|c|c|}
\hline is & Ap & & \\
\hline & 36 & in .................... & \\
\hline & $\times 12$ & in & 12, \\
\hline & × 24 & in. & \\
\hline & $\times 36$ & in. & \\
\hline & $\times 12$ & in. & 10. \\
\hline & $\times 18$ & in. & \\
\hline & $\times 2 t$ & in. & \\
\hline & $x \quad 30$ & in.. & \\
\hline & $\times 36$ & in.. & \\
\hline & $x 4$ & in. & \\
\hline & x 36 & & \\
\hline & $x \notin S$ & in & \\
\hline
\end{tabular}

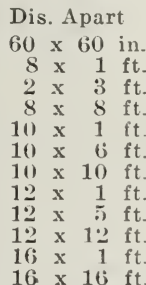
No. Plants

\section{QUANTITY OF SEED REQUIRED}

Alfalfa

Quantity per Acre

Alsyke 8 to $15 \mathrm{lbs}$

Artichoke, $1 \mathrm{oz}$. to 500 plants

Asparagus, $1 \mathrm{oz}$. to 500 plants

Barley

Beans, Dwarf, 1 lb. to 100 feet of drill.

6 to $15 \mathrm{lbs}$

Beans, Tall, $1 \mathrm{lb}$, to 150 hills

Bett, Garden, $1 \mathrm{oz}$, to 50 feet of drill

Beet, Sugar, $1 \mathrm{oz}$. to 50 feet of drill.

Beet, Mangel Wurzel, $1 \mathrm{oz}$. to 50 feet of drill

Broccoli, $1 \mathrm{oz}$. to 2,000 plants..

Brussels Sprouts, $1 \mathrm{oz}$, to 2,000 plants

Broom Corn

Buckwheat

Cabbage, 1 oz. to 1,500 plants

Carrot, $1 \mathrm{oz}$. to 125 feet of drill

Cauliflower, $1 \mathrm{oz}$. to 2,000 plants.

Celery, $1 \mathrm{oz}$. to 5,000 plants.

Cheat

$6 \mathrm{oz}$

$6 \mathrm{oz}$.

60 to $75 \mathrm{lbs}$

$50 \mathrm{lbs}$.

25 lbs.

5 lbs.

5 lbs.

$5 \mathrm{lbs}$.

$4 \mathrm{oz}$.

$4 \mathrm{oz}$.

12 lbs.

$45 \mathrm{lbs}$

$1 / 2$ lb.

3 lbs.

3 oz.

$1 \mathrm{lb}$.

Chicory, 1 oz. to 100 feet of drill

$100 \mathrm{lbs}$

Clover, White and Alsyke

$4 \mathrm{lbs}$

Clover, White for Lawns.

Clover, Red, Mammoth and Crimson..............12 to $20 \mathrm{lbs}$

Collards, $1 \mathrm{oz}$. to 2,000 plants.

Corn, Sweet, $1 \mathrm{lb}$. to 200 hills.

$4 \mathrm{oz}$.

Corn, Field

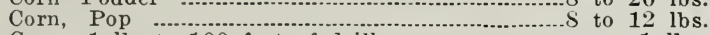

Cress, $1 \mathrm{lb}$. to 100 feet of drill.

Cucumber, $1 \mathrm{oz}$, to 60 hills

Egg Plant, $1 \mathrm{oz}$. to 2,000 plants

Endive, $1 \mathrm{oz}$. to 100 feet of drill

Flax, for seed, 30 lbs. to acre; for fiber

Grass, Lawn, $1 \mathrm{lb}$. to 300 square $\mathrm{ft}$.

Grass, Kentucky Blue, Canadian Blue.

Timothy

Red Top, in chaff, 60 lbs.; solid.

Rye Grass, Oat Grass, Fescue Grasses.

Orchard Grass

Hemp

4!) to 60 lbs.
Horse Radish Roots

Kale, $1 \mathrm{oz}$. to 150 feet of drill

Kale, Thousand Headed

Kohlrabi, $1 \mathrm{oz}$. to 150 feet of drill

Kaffir Corn

Leek, 1 oz to 100 feet of drill

Lettuce, $1 \mathrm{oz}$. to 150 feet of drill

Melon, Musk, 1 oz. to 60 hills...

Melon, Water, $1 \mathrm{oz}$. to 30 hills

Nasturtium, 1 oz. to 50 feet of drill

Oats

Okra, 1 oz. to 100 feet of drill

Onion, $1 \mathrm{oz}$. to 100 feet of drill

Onion, for sets

Onion Sets, $1 \mathrm{lb}$. to 75 feet of drill

Parsley, $1 \mathrm{oz}$. to 300 feet of drill.

Parsnip, $1 \mathrm{oz}$. to 200 feet of drill.

Peas, Garden, $1 \mathrm{lb}$. to 50 feet of drill.

Peas, Field

Pepper, 1 oz. to 100 plants.

Potatoes

Pumpkin, $1 \mathrm{oz}$. to 30 hills.

Radish, $1 \mathrm{oz}$. to 100 feet of drill

Rape, Dwarf Essex

Rutabaga, $1 \mathrm{cz}$. to 150 feet of drill

Rye

Salsify, $1 \mathrm{oz}$, to 50 feet of drill.

Speltz

Spinach, $1 \mathrm{oz}$. to 100 feet of drill

Squash, Summer. $1 \mathrm{oz}$. to 25 hills

Squash, Winter, $1 \mathrm{oz}$. to 12 hills.

Sugar Cane

Sunflower

Tobacco, 1 oz. to 10,000 plants.

Tomato, $1 \mathrm{oz}$. to 2,000 plants..

Turnip, $1 \mathrm{oz}$. to 150 feet of drill.

Vetches, Spring

Vetches, Winter

Wheat
Quantity per Acre 15,000 to 20,000

$1 \mathrm{lb}$.

2 lbs.

8 lbs.

+ lbs.

3 lbs.

4 lbs.

$30 \mathrm{lbs}$

15 lbs.

$\begin{array}{rl}75 & \mathrm{lbs} . \\ 8 & \mathrm{lbs} .\end{array}$

8 lbs.

$20 \mathrm{lbs}$

(0) lbs.

3 lbs.

$6 \mathrm{lbs}$.

$100 \mathrm{lbs}$

$400 \mathrm{lbs}$

4 lbs.

$10 \mathrm{lbs}$

$10 \mathrm{lbs}$

$2 \mathrm{lbs}$

8 lbs.

$100 \mathrm{lbs}$.

$8 \mathrm{lbs}$.

$3 \mathrm{lbs}$.

$10 \mathrm{lbs}$

$8 \mathrm{lbs}$

$3 \mathrm{oz}$.

$4 \mathrm{oz}$.

$2 \mathrm{lbs}$

60 to $90 \mathrm{lbs}$

30 to $60 \mathrm{lbs}$
60 to $80 \mathrm{lbs}$.

\section{WEIGHTS OF SEED PER BUSHEL}

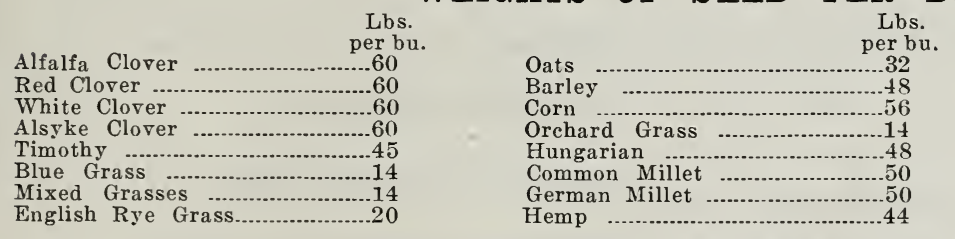

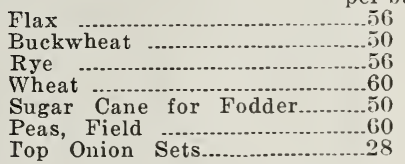

\section{USUAL DISTANCES FOR PLANTING}

Beans, Bush, drills 2 to 3 feet apart.

Beans, Pole, 3 to 4 feet each way.

Beets, Early, drills 12 to 18 inches apart.

Beets, Late, drills 2 to 3 feet apart.

Blackberries, erect growing, 6 to 9 by 4 feet.

Blackberries, Mammoth and Himalaya, 8 by 12 feet.

Cabbage, Early, 16 by 30 inches.

Cabbage, Late, 24 by 30 inches.

Carrots, drills 1 to 2 feet apart.

Corn, Sweet, 3 to $3 \frac{1 / 2}{2}$ feet by 9 to 24 inches.

Corn, Field, $3 \frac{1}{2}$ to 4 feet each way.

Cucumber, 4 to 5 feet each way.

Currants, 5 by 3 feet.

Egg Plant, 3 by 5 feet.

Lettuce, drills 18 inches apart.

Melon, Musk, 5 to 6 feet each way.

Celerv. rows 3 to 4 feet 6 inches in row.

Cherry Trees, 15 to 20 feet each way.

Cauliflower, 2 by 2 to 2 by 3 feet.

Apple Trees, 20 to 30 feet each way.

Asparagus, 3 to 4 by 2 feet.

Gooseberries, 5 by 3 feet.

Grapes, 8 by 8 to 10 by 12 feet.
Melon, Water, 7 to 8 feet each way.

Onions, drills 14 to 20 inches apart.

Parsnips, drills 18 to 36 inches apart.

Peach trees, 18 to 24 feet each way.

Pear Trees, Standard, 20 to 25 feet each way.

Pear Trees, Dwarf, 12 to 15 feet each way.

Peas, drills 2 to 3 feet apart.

Fepper, 15 to 18 inches by 2 to $2 \frac{1}{2}$ feet.

Plum Trees, 15 to 20 feet each way.

Potatoes, 12 to 18 inches by $2 \frac{1}{2}$ to 3 feet.

Pumpkins, 8 to 10 feet each way.

Quince Trees, 15 feet each way.

Radish, drills 10 to 18 inches apart.

Raspberries, 6 to 8 by 3 feet.

Rhubarb. 2 to 4 feet by 4 feet.

Salsify, drills 18 to 24 inches apart.

Spinach, drills 12 to 18 inches apart.

Squash, Bush, 3 to 4 feet by 4 feet.

Squash, Running, 12 feet each way.

Strawberries, Hills. 36 by 18 inches.

Strawberries, Matted Rows, 48 by 12 inches.

Sweet Potatoes, 2 feet by 3 to $t$ feet. 


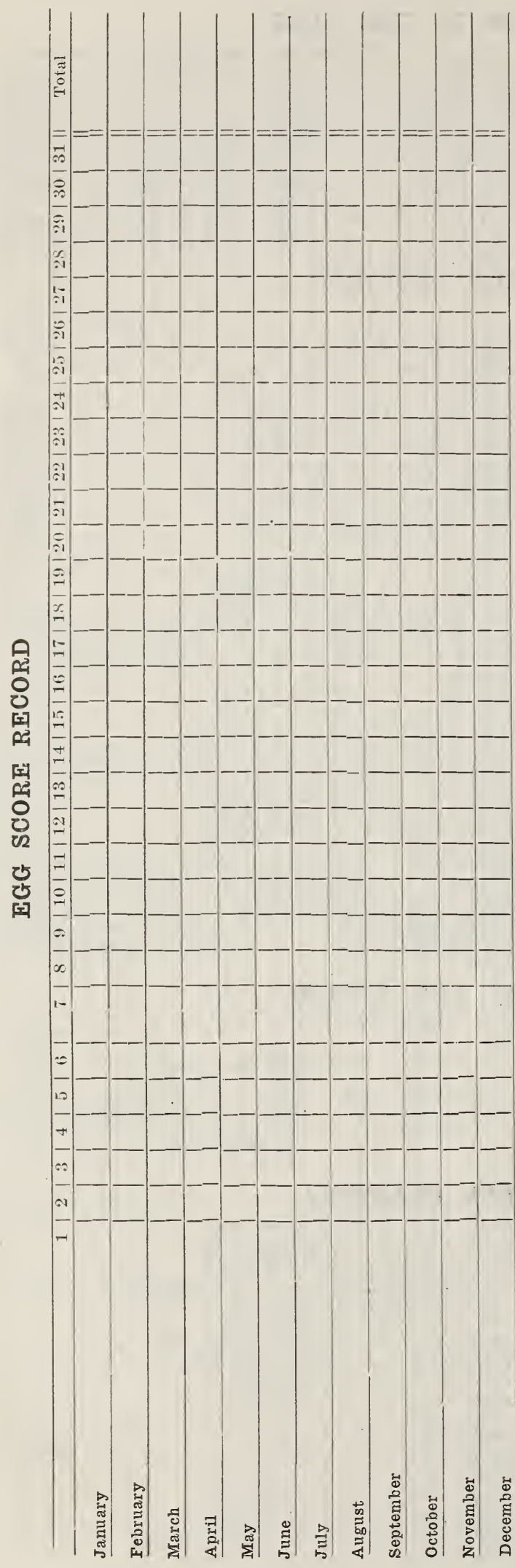

\section{PROFIT IN HENS}

Statistics show that in the neighborhood of one hundrea carloads of Eggs are shipped into Spokane each year. This, figured into round numbers, gives Seventeen Million Two Hundred and Eighty Thousand (17,280,000), some eggs. Some twelve years ago, upon the arrival of the first car of Cypher's Incubators shipped here, the writer well remembers the poultry men saying: "What will you do with all these incubators! If you sell all those here, eggs won't be worth anything." The years have rolled by, and many cars of incubators have gune from Spokane; but eggs are higher and scarcer today than then.

At the time this is going to press, the women throughout this country are agitating and working for the lower prices of eggs. It strikes us that in this vicinity, agitation for increased winter production is the solution. Probably not 30 per cent of all the poultry men in this vicinity make expenses auring the winter months. These 30 per cent have the proper buildings, know how and what to feed, ana give their hens the care necessary to produce winter eggs.

In order to assist the poultry men, we have prepared from the best grains, alfalfa, etc., the following:

\section{CLOVED LEAF CHICK FEED \\ CLOVER LEAF FORCING FEED. \\ CLOVER LEAF BALANCED RATIONS. \\ CLOVER LEAF SCRATCH FEED.}

In addition to these, oyster, grit, bone, meat and sprouted oats should bt fed generously. 


\section{Clover Leaf Brand}

We wish to call especial attention to our Clover Leaf Brands of Poultry Feed. We use only the best of grains in their makeup, and our constant aim is to produce the very best article that can be produced. $\mathrm{T}$ hese brands of feed are handled by merchants in nearly every city or village in th e Inland Empire. If unable to procure them of your merchant, we will be glad to forw ard them as per prices listed below.

CLOVER LEAF CHICK FEED

Price, 6 lbs., 25c; 25 lbs., 80c; 50 lbs., $\$ 1.50 ; 100$ lbs., $\$ 2.75$.

CLOVER LEAF FORCING FEED

Price, 50 lbs., $\$ 1.35 ; 100$ lbs., $\$ 2.50$.

CLOVER LEAF BALANCE RATION

Price, $80 \mathrm{lb}$. sack $\$ 1.50$.

CLOVER LEAF SCRATCH FEED

Price, 100 lb. bag, $\$ 2.00$.

CLOVER LEAF GRIT

Price, $100 \mathrm{lb}$. bag, $\$ 1.00$.

Watch for the brand, a Clover Leaf on every sack. THE INLAND SEED C0., 913-915 First Ave., Spokane, Wash. 


\section{N D E X}

\begin{tabular}{|c|c|c|}
\hline Page & Page & \\
\hline 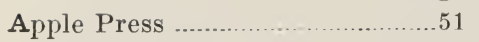 & ormaldehyde & Planters, Corn \\
\hline 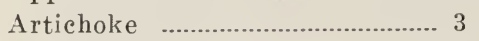 & Food Hoppers & Planters, Potato \\
\hline sparagus & 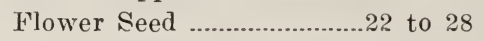 & Plant Setters ............................. \\
\hline lfalfa & Fruit Picking Bag..... & Potatoes \\
\hline - & Feed .................................... & Poultry Punches .... \\
\hline ............. $4-5$ & Feed Grinders ... & 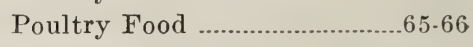 \\
\hline Bee Supplies .............. & Garlic & Poultry Remedies …...67-68-69-70 \\
\hline Bone Cutters ........... & Grain Sprouter & Pruning Tools \\
\hline ooks & 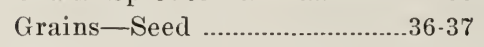 & Pumpkins \\
\hline$\ldots . .70$ & $\ldots 33-34$ & vder Blowers ......................... \\
\hline ............ 70 & $\ldots \ldots . .50$ & $\ldots \ldots \ldots \ldots \ldots . . .51$ \\
\hline 51 & Grit Machine .. & $\ldots 17$ \\
\hline$\ldots$ & .............20 & \\
\hline $56 \cdot 57 \cdot 58$ & 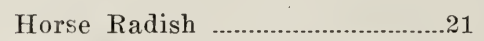 & ulators \\
\hline$\ldots$ & Hose .............................. & $\mathrm{rb}$ \\
\hline$\ldots$ & Hygrometer .... & $\mathrm{g}$ \\
\hline 35 & Incubators ................. & Roots \\
\hline 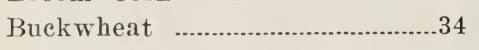 & 10 & 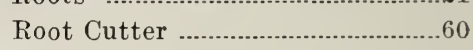 \\
\hline$\ldots 29-30$ & $\ldots . . .10$ & \\
\hline ................. & 35 & $-39-40$ \\
\hline$\ldots \ldots . .5$ & $\ldots . . .58$ & 43 \\
\hline 66 & s, Incubators ….................... & 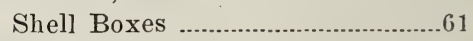 \\
\hline 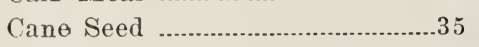 & 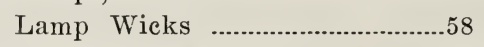 & $\ldots+.43$ \\
\hline aipping …............................. & p Burners ............................. & $-46-47$ \\
\hline$\ldots . .63$ & ........11 & \\
\hline$\ldots . .60$ & …...62 & .......... $49-50-51$ \\
\hline$\ldots \ldots . .42$ & $\ldots \ldots . .51$ & tors $\ldots . . . . . . . . .43$ \\
\hline$\ldots \ldots . . .41$ & $\ldots . . .34$ & Extras ................... \\
\hline prots & $\ldots 10-11$ & Squirrel Poison ......................... 70 \\
\hline 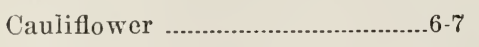 & $\ldots \ldots . .12$ & \\
\hline ….. 7 & $\ldots \ldots .13$ & $\ldots 35$ \\
\hline 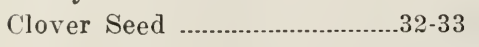 & $\ldots .34$ & $\ldots .67-68-69$ \\
\hline Corn & $\ldots . .35$ &. .18 \\
\hline 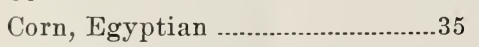 & Spawn & \\
\hline ....... 9 & $\ldots .11$ & t \\
\hline 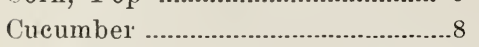 & $\ldots . . .59$ & meters, Incubator \\
\hline tivators & $\ldots . . . .62$ & $\ldots$ \\
\hline C'ress & $\ldots . .62-63$ & meters, Dairy . \\
\hline Cream Separators …..................... & $\ldots . . .47$ & $\ldots . .50$ \\
\hline Drinking $\mathrm{F}$ & $\ldots . . .14$ & $\ldots 20$ \\
\hline Do: $B$ & $\ldots . .58$ & acco Dust \\
\hline Dog Remedies ........................69 & Oil Meal .... & Tomatoes .......... \\
\hline Electric Alarm System..............57 & Onion Seed & Tree Labels ...... \\
\hline gggs for Setting.... & Onion Sets & Tree Seed \\
\hline Egg Boxes & Parsley .. & Turnips ...... \\
\hline Egg Plant ........................................ & Parsnips ......... & Trowels, Garden \\
\hline Egg S'core & Peas, Garden & Vetehes ................ \\
\hline Egg Tester ........... & Peas, Field ... & Vines ... \\
\hline Egg Carrier .... & Peanuts. & $\begin{array}{l}\text { Vines } \\
\text { Weede }\end{array}$ \\
\hline Endive & $\begin{array}{l}\text { Peppers } \\
\text { Plants }\end{array}$ & $\begin{array}{l}\text { Weeders, Hand } \\
\text { Wire, Poultry . }\end{array}$ \\
\hline Fertilizers & 'Plants …….......................... & \\
\hline
\end{tabular}




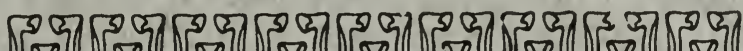

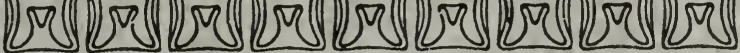

\section{We are Exclusive Agents for}

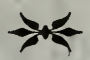

Bean Spray Pumps

Grasseli's Arsenate of Lead

De Laval Cream Separators

Cyphers Incubators and Brooders

Cycle Hatchers

Conkey's Remedies

Gold Coin Remedies

Automatic Fount and Feeder

Wilson Bottomless Fruit Picking Bags

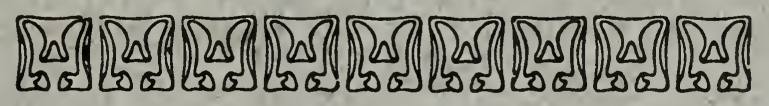




\section{CLOVER LEAF BRAND}

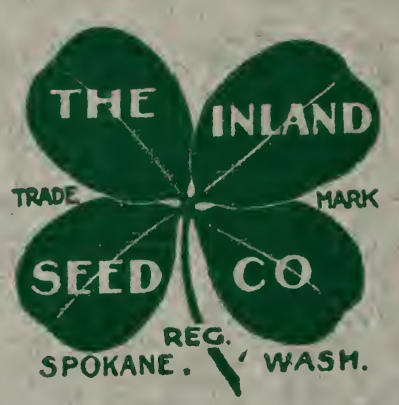

\section{STANDS FOR QUALITY}

